Proceedings of the

18th International Conference

\title{
Work and Organizational Psychology 2019
}

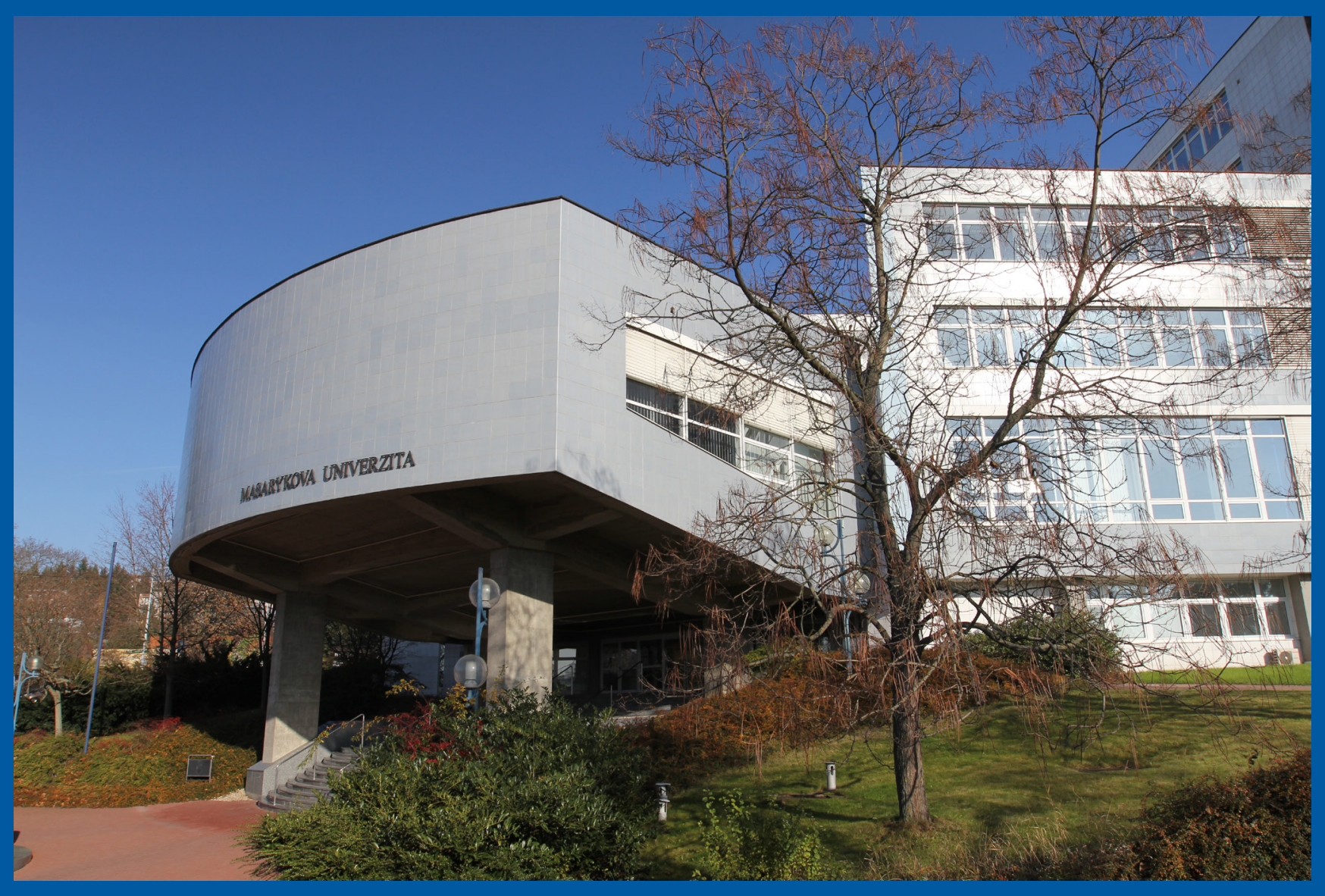

Sborník př́spěvků z 18. mezinárodní konference

\section{Psychologie práce a organizace 2019}

\author{
MA S A R Y K \\ U II I V E R S I T Y \\ PRESS
}



Konference psychologie práce a organizace

II U II I

PRESS 

JAKUB PROCHÁZKA，

TOIIÁŠ KRATOCHVÍL,

IIARTIII VACULÍK (EDS.)

IIORK A II D ORGAIIIZAT I O IIAL

PSYCHOLOGY 2019

$18^{\text {TH }}$ INTERNATIONAL

CONFERENCE PROCEEDINGS

PSYCHOLOGIE PRÁCE A ORGAIIIZACE 2019

SBORNÍK PR̈ÍSPËVKŮ

Z 18. MEZINÁRODNí KONFERENCE 



\section{Editors:}

Jakub Procházka, Tomáš Kratochvíl, Martin Vaculík

\section{Authors:}

Viera Bačová, Radvan Bahbouh, Radvan Bahbouh, Jozef Bavol'ar, Zuzana Birknerová, Milan Bobek, Agnieszka Bożek, Miroslava Bozogáňová, Denisa Drabová, Milan Droppa, Ivana Fabianová, Denisa Fedáková, Michal Franc, Miroslav Frankovský, Vít Gabrhel, Aleš Gregar, Zuzana Heinzová, Zuzana Heinzová, Eva Höschlová, Chun-Hua Hu, Eva Chroustová, Mojmír Kališ, Michal Kentoš, Alžběta Knorková, Zuzana Kožárová, Zuzana Kožárová, Klaudia Kubalová, Rudolf Kubík, Olexandr Kushch, Václav Linkov, Elena Lisá, Jana Lišková, Tatiana Lorincová, Tatiana Lorincová, Vladimíra Lovasová, Alexander Loziak, Shiao-Tzu Ma, Diana Malinowska, Jana Matošková, Ivana Ondrijová, Lucia Pašková, Lucia Pašková, Karel Paulík, Ivana Pejřová, Vladimír Poliach, Vladimír Poliach, Bahbouh Radvan, Eva Sollárová, Eva Sollárová, Jana Marie Šafránkov, Martin Šikýř, Aleksandra Tokarz, Ivana Toman Čergot’ová, Lenka Valuš, Andrea Zelienková, Beata Žitniaková-Gurgová, Beata Žitniaková-Gurgová

\section{Reviewers:}

Katarína Baňasová, Jozef Bavolár, Miroslava Bozogáňová, Marek Dobeš, Denisa Fedáková, Miroslava Galasová, Jaroslav Gottfried, Aleš Gregar, Eva Höschlová, Miriama Hudáková, Pavol Kačmár, Ludmila Kašpárková, Michal Kentoš, Tomáš Kratochvíl, Zuzana Lazišt’anová, Marcela Leugnerová, Markéta Niederlová, Petr Palíšek, Juraj Petrík, Ivana Piterová, Jakub Procházka, Martina Romanová, Milan Rymeš, Martin Seitl, Eva Š́rová, Matúš Šucha, Martin Vaculík, Jozef Výrost

\section{Author of the photo on the cover: Jan Nepovím}

All rights reserved. This work or any part of it cannot be reproduced, stored in information systems or otherwise distributed without the prior consent of the copyright owners.

The publication has not been proofread. The authors of the articles are responsible for the proofreading and the content.

(C) 2019 Masaryk University and the author of the contributions

ISBN 978-80-210-9488-8 (online; pdf)

https://doi.org/10.5817/CZ.MUNI.P210-9488-2019 


\section{Introduction}

The 18th International Conference Work and Organizational Psychology 2019 took place in Brno, Masaryk University on 22-23 May 2019. Over 130 participants and guests watched and listened to 64 contributions from academics and practitioners from 10 different countries. The topic of the contributions covered various areas of work and organization psychology and related fields. Most represented were psychometric contributions focused on methods used to measure work-psychology constructs, contributions focused on work psychology in the context of educational institutions and contributions devoted to the application of knowledge of occupational psychology in organizations. Applied psychological disciplines were also significantly represented.

In this book, there are 24 selected studies, presented in the form of a lecture or a poster at the conference and then positively reviewed by two reviewers. We would like to thank our colleagues from Charles University, Palacký University in Olomouc, Tomas Bata University in Zlín, Masaryk University, Comenius University in Bratislava, Constantine the Philosopher University in Nitra, P. J. Šafárik University in Košice and the Slovak Academy of Sciences for helping with the organization of the conference and for cooperation in the review process. We wish to the readers of the proceedings to find interesting information and inspiration for their own praxis.

This conference in Brno was also a jubilee conference. In 2019 it was 20 years since the 1st Conference on Work and Organizational Psychology in Slovakia. Therefore, we wish the conference a lot of interesting contributions, stimulating meetings and established cooperation over the next 20 years.

Jakub Procházka, Tomáš Kratochvíl a Martin Vaculík, editors of the conference proceedings 


\section{Úvodem}

Ve dnech 22.-23.5.2019 se v Brně na půdě Masarykovy univerzity uskutečnil 18. ročník mezinárodní konference Psychologie práce a organizace 2019. Celkem 130 účastníků a hostů zhlédlo a vyslechlo 64 př́spěvků od akademiků i odborníků z praxe z 10 různých zemí. Př́spěvky tématicky pokrývaly různé oblasti psychologie práce a organizace a blízkých oborů. Nejvíce byly zastoupeny psychometrické příspěvky zaměřené na metody sloužící k měření pracovně-psychologických konstruktů, př́spěvky zaměřené na pracovní psychologii v kontextu vzdělávacích institucí a př́íspěvky věnované aplikaci poznatků z pracovní psychologie v organizacích. Významně byly zastoupeny také aplikované psychologické disciplíny.

Ve sborníku z konference najdou čtenáři 24 vybraných studií, které byly na konferenci představeny formou přednášky nebo posteru a následně získaly kladné stanovisko od dvou recenzenti̊. Děkujeme kolegům z Univerzity Karlovy, Palackého univerzity v Olomouci, Univerzity Tomáše Bati ve Zlíně, Masarykovy univerzity, Komenského univerzity v Bratislavě, Univerzity Konštantína Filozofa v Nitře, Univerzity P. J. Šafárika v Košicích a ze Slovenské akademie věd za pomoc s organizací konference a za spolupráci v recenzním řízení. Přejeme čtenářum sborníku, aby $\mathrm{v}$ jednotlivých příspěvcích nalezli zajímavé informace a inspiraci pro vlastní výzkum nebo praxi.

Brněnská konference byla zároveň jubilejní konferencí, nebot' v roce 2019 uplynulo 20 let od prvního ročníku konaného na Slovensku. Přejeme proto konferenci do dalších 20 let hodně zajímavých prríspěvků, podnětných setkání a navázaných spoluprací.

Jakub Procházka, Tomáš Kratochvíl a Martin Vaculik, editoři sborníku 


\section{Content}

\section{Contributions in English}

The Intolerance of Uncertainty Scale - psychometric characteristics of the Slovak version, associations with related constructs and applications in work psychology

Jozef BAVOLÁR

Engagement in actions beyond basic professional duties - measurement and correlates

Agnieszka BOŻEK, Diana MALINOWSKA, Aleksandra TOKARZ

Starting an entrepreneurial career: Young entrepreneurs' profiles

Denisa FEDÁKOVÁ, Zuzana KOŽÁROVÁ.

The effect of manager's frequency and quality of communication on team's performance

Michal FRANC, Radvan BAHBOUH, Rudolf KUBÍK

Replication of psychometric analysis of the 4Elements Inventory (4EI) in the general population

Eva HÖSCHLOVÁ, Radvan BAHBOUH

Validation of the Emotion Recognition Test

Radvan BAHBOUH, Ivana FABIANOVÁ, Alžběta KNORKOVÁ, Eva CHROUSTOVÁ

\section{Contributions in Czech or Slovak}

Think of your financial future

Viera BAČOVÁ, Lenka VALUŠ

New creativity and innovativeness inventory Creatixo (CIQ-CXO) - its formation and pilot verification

Milan BOBEK

Attitudes towards migrants in the Slovak population based on Eurobarometerdata (2017)

Miroslava BOZOGÁŇOVÁ, Tatiana LORINCOVÁ

Assessment of bossing and mobbing manifestations in the context of personality traits of employees

Miroslav FRANKOVSKÝ, Zuzana BIRKNEROVÁ, Milan DROPPA

Smart Factory. What Employees Will the Company Need in the Future?

Aleš GREGAR, Ivana PEJŘOVÁ, Jana MATOŠKOVÁ

The Causes and Context of Job Insecurity in Slovakia

Michal KENTOŠ 
Job Satisfaction and Personality Characteristics in Connection with the Change of Body Constitution

Klaudia KUBALOVÁ, Ivana TOMAN ČERGEŤOVÁ

Perception of motorbike riding safety in Taiwan and the Czech Republic

Václav LINKOV, Vít GABRHEL, Chun-Hua HU, Shiao-Tzu MA. 136

The psychometric characteristics of the Hexaco-100 questionnaire used in the selection and non-selection situation

Elena LISÁ, Mojmír KALIŠ 144

The reflection of transformational, pseudotransformational and laissez-faire leadership in employee engagement, trust and innovation (pilot phase - movie method)

Jana LIŠKOVÁ, Denisa DRABOVÁ 154

Consumer behavior in the context of selected socio-demographic characteristics

Tatiana LORINCOVÁ, Ivana ONDRIJOVÁ. 164

Internal Factors of Work Satisfaction of Employees in Manufacturing Companies in the Czech Republic

Vladimíra LOVASOVÁ, Olexandr KUSHCH 171

Effectiveness of mindfulness training programs in improving work stress management in teachers

Alexander LOZIAK

Sense of meaningfulness of work and satisfaction of grammar school teachers

Karel PAULÍK

Leadership in Education - Characteristics of the Key Concepts

Eva SOLLÁROVÁ, Vladimír POLIACH, Lucia PAŠKOVÁ, Zuzana HEINZOVÁ, Beata ŽITNIAKOVÁ-GURGOVÁ. 198

Employees' opinions to management in SMEs in the Czech Republic

Jana Marie ŠAFRÁNKOVÁ, Martin ŠIKÝŘ 208

Effect of entrepreneurial education on development of entrepreneurial competencies

Andrea ZELIENKOVÁ, Zuzana KOŽÁROVÁ 216

Leadership Competency Models within the Educational Setting

Eva SOLLÁROVÁ, Vladimír POLIACH, Lucia PAŠKOVÁ, Zuzana HEINZOVÁ, Beata ŽITNIAKOVÁ-GURGOVÁ. 225 


\section{Obsah}

\section{Př́spěvky $v$ angličtině}

The Intolerance of Uncertainty Scale - psychometric characteristics of the Slovak version, associations with related constructs and applications in work psychology

Jozef BAVOLÁR

Engagement in actions beyond basic professional duties - measurement and correlates

Agnieszka BOŻEK, Diana MALINOWSKA, Aleksandra TOKARZ

Starting an entrepreneurial career: Young entrepreneurs' profiles

Denisa FEDÁKOVÁ, Zuzana KOŽÁROVÁ.

The effect of manager's frequency and quality of communication on team's performance

Michal FRANC, Radvan BAHBOUH, Rudolf KUBÍK

Replication of psychometric analysis of the 4Elements Inventory (4EI) in the general population

Eva HÖSCHLOVÁ, Radvan BAHBOUH 53

Validation of the Emotion Recognition Test

Radvan BAHBOUH, Ivana FABIANOVÁ, Alžběta KNORKOVÁ, Eva CHROUSTOVÁ

\section{Příspěvky v češtině nebo slovenštině}

Mysliet' na svoju finančnú budúcnost'

Viera BAČOVÁ, Lenka VALUŠ

Tvorba a pilotní ověření nového inventáře kreativity a inovativnosti Creatixo (DKI-CXO)

Milan BOBEK

Postoje k migrantom v slovenskej populácií na základe údajov Eurobarometra (2017)

Miroslava BOZOGÁŇOVÁ, Tatiana LORINCOVÁ

Posudzovanie prejavov bossingu a mobbingu v kontexte osobnostných čŕt zamestnancov

Miroslav FRANKOVSKÝ, Zuzana BIRKNEROVÁ, Milan DROPPA 101

Smart Factory. Jaké zaměstnance bude firma potřebovat $\mathrm{v}$ budoucnu?

Aleš GREGAR, Ivana PEJŘOVÁ, Jana MATOŠKOVÁ

Príčiny a kontexty pracovnej neistoty na Slovensku

Michal KENTOŠ 
Pracovní spokojenost a osobnostní charakteristiky $v$ souvislosti se změnou tělesné konstituce

Klaudia KUBALOVÁ, Ivana TOMAN ČERGEŤOVÁ

Vnímání bezpečnosti řízení motocyklů na Taiwanu a v České republice

Václav LINKOV, Vít GABRHEL, Chun-Hua HU, Shiao-Tzu MA.

Psychometrické charakteristiky dotazníka Hexaco-100 použitého vo výberovej a nevýberovej situácii

Elena LISÁ, Mojmír KALIŠ 144

Reflexia transformačného, pseudotransformačného a laissez-faire leadershipu v angažovanosti, dôvere a inovácii zamestnancov (pilotná fáza - metóda filmu)

Jana LIŠKOVÁ, Denisa DRABOVÁ 154

Spotrebitel'ské správanie v kontexte vybraných socio-demografických charakteristík

Tatiana LORINCOVÁ, Ivana ONDRIJOVÁ. 164

Vnitřní faktory pracovní spokojenosti zaměstnanců ve výrobních podnicích v ČR

Vladimíra LOVASOVÁ, Olexandr KUSHCH

Efektivita mindfulness tréningov v zlepšení zvládania pracovného stresu u učitel’ov

Alexander LOZIAK

Smysluplnost práce a spokojenost učitelů gymnázií

Karel PAULÍK

Líderšip v edukácii - charakteristika kl’účových konceptov

Eva SOLLÁROVÁ, Vladimír POLIACH, Lucia PAŠKOVÁ, Zuzana HEINZOVÁ, Beata ŽITNIAKOVÁ-GURGOVÁ. 198

Názory zaměstnanců na management v MSP v České republice

Jana Marie ŠAFRÁNKOVÁ, Martin ŠIKÝŘ 208

Efekt podnikatel'ského vzdelávania na rozvoj podnikatel'ských kompetencií

Andrea ZELIENKOVÁ, Zuzana KOŽÁROVÁ 216

Kompetenčné modely líderstva v edukačnom prostredí

Eva SOLLÁROVÁ, Vladimír POLIACH, Lucia PAŠKOVÁ, Zuzana HEINZOVÁ, Beata ŽITNIAKOVÁ-GURGOVÁ. 


\title{
CONTRIBUTIONS IN ENGLISH \\ PŘÍSPĚVKY V ANGLIČTINĚ
}

\section{The Intolerance of Uncertainty Scale - psychometric characteristics of the Slovak version, associations with related constructs and applications in work psychology}

Jozef Bavol'ár ${ }^{1}$

${ }^{1}$ Pavol Jozef Šafárik University in Košice, Faculty of Arts, Department of Psychology, Slovakia

\begin{abstract}
Objective. The study presents the Slovak version of the Intolerance of Uncertainty Scale with the aim of examining its factor structure and construct validity through relationships with related variables. It also aims to sketch the possibilities of applying it in work psychology.

Method. The study consists of two datasets which included a total of 220 subjects (age 21-60, mean age 36.7, 59.5\% females). The participants completed four self-reported measures Intolerance of Uncertainty (Carleton, Norton, \& Asmundson, 2007), Domain-Specific RiskTaking (Blais \& Weber, 2006), Indecisiveness Scale (Frost \& Shows, 1993) and the Decision Outcomes Inventory (Bruine de Bruin, Parker, \& Fischhoff, 2007).

Results. The factor structure and internal consistency of the Slovak version of the Intolerance of Uncertainty Scale was confirmed. Indecisiveness was found to be related to only one factor - inhibitory uncertainty. The intolerance of uncertainty was associated more with risk perception than with risk-taking and no relationship with decision outcomes was found.

Conclusions. The Slovak version of the Intolerance of Uncertainty Scale is an appropriate tool for measuring this construct. The results of the analysis highlight the importance of distinguishing its two factors - prospective and inhibitory anxiety.

Limitations. The study is restricted by the absence of variables more directly related to the role of the intolerance of uncertainty in a work environment.

Keywords. intolerance of uncertainty; psychometrics; risk perception; indecisiveness; decision outcomes

https://doi.org/10.5817/CZ.MUNI.P210-9488-2019-1
\end{abstract}




\section{Introduction}

People have a general tendency to prefer known risk over unknown distribution (e.g., ambiguity aversion (Ellsberg, 1961)). However, their attitudes to uncertainty differ in real life which has resulted in establishing the personality characteristic intolerance of uncertainty (for a closer look at the similarities and differences between the intolerance of uncertainty and intolerance of ambiguity, see Grenier, Barrette, \& Ladouceur, 2005). While the intolerance of uncertainty (IU) was previously defined as a broad construct reflecting cognitive, emotional, and behavioural reactions to uncertainty in everyday situations (Shihata, McEvoy, Mullan \& Carleton, 2016), it is currently considered to be the dispositional inability of individuals to tolerate aversive reactions due to the perceived lack of sufficient information (Bottesi, Noventa, Freeston, \& Ghisi, 2019). Ladouceur, Gosselin, \& Dugas (2000) have described IU as "the predisposition to react negatively to an uncertain event or situation, independent of its probability of occurrence and its associated consequences" (p934). IU has been found to be particularly related to psychopathology (Shihata et al., 2016) although it also manifests itself in the work and organizational context (Borchers, 2005; Seely, 2013; Williams \& Clampitt, 2003). As a result, the need for an IU measurement in Slovakia has arisen. This study aims to present the Slovak version of the mostly used self-reported measure - the Intolerance of Uncertainty Scale-12 (IUS-12) and to sketch the possibilities of applying it in the work and organizational environment based on IU in real behaviour (risk taking, decision-making).

\section{Intolerance of uncertainty in the organizational environment}

While IU has mainly been investigated in the context of emotional disorders and psychopathology (e.g., anxiety, depression, obsessive-compulsive disorder; Gentes \& Ruscio, 2011), some of its general consequences have had clear implications in work psychology and some studies have directly focused on its role in the organizational environment. Moreover, the importance of this construct is emphasized by the fact that uncertainty is present in almost every decision and the tendency to seek or avoid it can have a serious impact on it. In addition, some aspects of IU can affect work behaviour to a great extent. There are several examples of IU visible in the work environment such as information-seeking behaviour as a consequence of high IU (Rosen \& Knäuper, 2009), prospective IU as a vulnerability factor in excessive avoidance behaviour (Flores, López, Vervliet, \& Cobos, 2018) and the contribution of IU to the initial level of behavioural risk (Kornilova, Chumakova, \& Kornilov, 2018). IU is also related to negative problem orientation, limited access to emotion regulation (Ouellet, Langlois, Provencher, \& Gosselin, 2019) and lower creativity (Kornilova \& Kornilov, 2010). With regards to the role of IU in psychopathology, the identification of individuals with high IU can help with the prevention of severe emotional disorders, e.g. by providing counselling services.

Other studies have directly investigated IU in the work environment. Clampitt, Williams, and DeKoch (2007) have reported that organizations which embrace uncertainty foster more employee commitment, greater job satisfaction and that their employees are able to cope better with change. This pattern is independent of employees rating of their own uncertainty management skills and organizations can even cultivate an uncertainty-embracing climate. The tolerance to uncertainty at a personal level as well as in work situations in teachers was found 
to be positively related to job-related affective well-being and psychological need satisfaction (Kamel \& Hashish, 2015). However, psychological uncertainty has not been found to be related to counterproductive work behaviour (Norwood, 2018). Uncertainty management affects job satisfaction and innovation (Lane \& Bocarnea, 2011). On the other hand, students high in IU have been found to be more likely to make incorrect clinical decisions, although only in one of the four provided situations (Innes, Leboeuf-Yde, \& Walker, 2017).

\section{Measuring the intolerance of uncertainty}

IU has predominantly been measured by self-reported measures with the Intolerance of Uncertainty Scale being the dominant one (IUS, Freeston, Rhéaume, Letarte, Dugas, \& Ladouceur, 1994). It consists of 27 items grouped into five factors (unacceptability and avoidance of uncertainty, negative social evaluation caused by uncertainty, uncertainty-related frustration, uncertainty causes stress, uncertainty preventing action) although it is the short form of the scale (IUS-12, Carleton, Norton, \& Asmundson, 2007) which is most currently used. The twelve items are divided into two factors - prospective anxiety (fear and anxiety based on future events) and inhibitory anxiety (uncertainty inhibiting action or experience). Recently, Lauriola et al. (2018) presented the Intolerance of Uncertainty Inventory focused on IU and its consequences. With the exception of factor structure, the validations of these measures have mainly focused on the relationships with selected symptoms of psychopathology such as worry, anxiety and depression. In the current study, the aim is to investigate the construct validity of the scale through the correlations with other variables. It is expected that there will be a positive relationship with indecisiveness and risk perception and negative relationships with risk taking and decision outcomes.

\section{Method}

\section{Sample}

Two samples were used in the current study. The first sample consisted of 100 respondents aged 23 to 59 years (mean age 32.9, $\mathrm{SD}_{\text {age }}=9.28,50 \%$ females, $68 \%$ secondary school, $32 \%$ university education). The second sample included 120 participants aged 21 to 60 years (mean age 39.9, $\mathrm{SD}_{\text {age }}=15.07,67.5 \%$ females, $48 \%$ secondary school, $52 \%$ university education). All participants were employed and there was no profession which was more frequent than $5 \%$. There were three variables measured in both samples - intolerance of uncertainty, risk perception and risk taking - although decision outcomes were only measured in the first sample and indecisiveness only in the second sample.

\section{Measures}

The intolerance of uncertainty was measured by the short version of the Intolerance of Uncertainty scale (IUS-12, Carleton, Norton, \& Asmundson, 2007) which consists of 12 items divided into two factors - prospective anxiety ( 7 items, e.g., It frustrates me not having all the information I need) and inhibitory anxiety (5 items, e.g., When it's time to act, uncertainty 
paralyses me). The items were rated from not at all characteristic of me (1) to entirely characteristic of me (5). The scale was translated into Slovak and back-translated into English by another person and the translations were compared to ensure their equivalence.

Domain-Specific Risk-Taking scale(DOSPERT, Blais \& Weber, 2006) was used to measure risk perception and propensity to risk-taking. There are 30 items divided into five domains (ethical, financial, health/safety, recreational, social) which are presented twice with different instructions and response formats. Firstly, subjects were asked how risky each of the given situations are (from 1-not at all risky to 7-extremely risky) and subsequently what is the likelihood of them engaging in this activity (from 1-extremely unlikely to 7-extremely likely). A higher score (total and in each domain) means a higher perceived risk; in other words, a greater likelihood of engaging in risky behaviour.

Indecisiveness was assessed by the short version of the Indecisiveness Scale (Bavolar, 2018) which contains 9 items asking about symptoms of indecisiveness (e.g., I try to put off making decisions) rated on a scale from 1 (strongly disagree) to 5 (strongly agree), some items reversed.

The Decision Outcome Inventory (Bruine de Bruin, Parker, \& Fischhoff, 2007) was used to assess decision outcomes. The items in this measure ask about the occurrence of selected negative decision outcomes (e.g., missed a flight) given a prerequisite (take a trip by airplane). The final score ranges from -1 to 0 with higher values reflecting better decision outcomes (fewer wrong outcomes).

\section{Results}

The first step of the data analysis was a confirmative factor analysis with the 12 items divided into prospective anxiety ( 7 items) and inhibitory anxiety ( 5 items). The first solution was found to have unsatisfactory fit indices $\left(\chi^{2}=126\right.$, $\mathrm{df}=53, \mathrm{p}<.001$, RMSEA $=.08, \mathrm{CFI}=$ .89 ), but after adding covariances in three pairs of items as indicated by the modification indices (items 8-9 in prospective anxiety and 6-7 and 6-10 in inhibitory anxiety), the fit indices were in the required intervals $(\chi 2=81.6, \mathrm{df}=50, \mathrm{p}=.003, \mathrm{RMSEA}=.05, \mathrm{CFI}=.95)$.

The second step involved examining the relationships of intolerance of uncertainty and its subscales with other included variables - risk perception, risk-taking, indecisiveness, and decision outcomes. These correlations, along with the descriptive statistics, are presented in Table 2.

Generally, IU was positively related to risk perception, mainly in the recreational and social domains, although the associations with risk-taking were very weak. IU was also not significantly related to decision outcomes. The pattern of correlations of prospective and inhibitory anxiety was only different in the case of indecisiveness which was positively related to inhibitory, but not to prospective anxiety (the relationships of indecisiveness and decision outcomes are presented in Appendix A). 
Table 1. Descriptive statistics and factor loadings for Intolerance of Uncertainty Scale items

\begin{tabular}{|c|c|c|c|c|c|c|c|}
\hline $\begin{array}{l}\text { UIS-12 items } \\
\text { English }\end{array}$ & $\mathrm{x}$ & Mdn & SD & Skew. & Kurt. & $\begin{array}{r}\mathrm{Fac} \\
\text { load }\end{array}$ & \\
\hline Slovak & & & & & & $\begin{array}{l}\text { Prosp. } \\
\text { anx. }\end{array}$ & $\begin{array}{l}\text { Inhib. } \\
\text { anx. }\end{array}$ \\
\hline $\begin{array}{l}\text { 1. Unforeseen events upset me greatly } \\
\text { Nepredvidatel'né udalosti ma vel'mi rozrušia. }\end{array}$ & 2.71 & 3.00 & 1.04 & 0.42 & -0.14 & 0.57 & \\
\hline $\begin{array}{l}\text { 2. It frustrates me not having all the } \\
\text { information I need. } \\
\text { Znepokojuje ma, ak nemám všetky } \\
\text { informácie, ktoré potrebujem. }\end{array}$ & 3.56 & 4.00 & 1.10 & -0.35 & -0.72 & 0.60 & \\
\hline $\begin{array}{l}\text { 3. Uncertainty keeps me from living a full } \\
\text { life. } \\
\text { Neistota mi bráni žit' môj život naplno. }\end{array}$ & 2.65 & 3.00 & 1.37 & 0.27 & -1.16 & & 0.74 \\
\hline $\begin{array}{l}\text { 4. One should always look ahead so as to } \\
\text { avoid surprises. } \\
\text { Človek by mal vždy pozerat' dopredu, aby sa } \\
\text { vyhol prekvapeniam. }\end{array}$ & 3.27 & 3.00 & 1.15 & -0.18 & -0.71 & 0.42 & \\
\hline $\begin{array}{l}\text { 5. A small unforeseen event can spoil } \\
\text { everything, even with the best of planning. } \\
\text { Malá nepredvídatel'ná udalost' môze všetko } \\
\text { pokazit', dokonca aj napriek perfektnej } \\
\text { organizácii. }\end{array}$ & 2.64 & 3.00 & 1.15 & 0.25 & -0.66 & 0.66 & \\
\hline $\begin{array}{l}\text { 6. When it's time to act, uncertainty } \\
\text { paralyses me. }\end{array}$ & 2.36 & 2.00 & 1.16 & 0.54 & -0.59 & & 0.49 \\
\hline $\begin{array}{l}\text { Ked' je čas konat', ochromuje ma neistota. } \\
7 \text {. When I am uncertain, I can't function very } \\
\text { well. } \\
\text { Ked' som si neistý, nemôžem vel'mi dobre } \\
\text { fungovat.' }\end{array}$ & 2.78 & 3.00 & 1.15 & 0.12 & -0.89 & & 0.61 \\
\hline $\begin{array}{l}\text { 8. I always want to know what the future has } \\
\text { in store for me. } \\
V z ̌ d y \text { chcem vediet', čo mi budúcnost' } \\
\text { prinesie. }\end{array}$ & 2.85 & 3.00 & 1.27 & 0.12 & -1.02 & 0.47 & \\
\hline $\begin{array}{l}\text { 9. I can't stand being taken by surprise. } \\
\text { Nemôžem ostat' prekvapený/á. }\end{array}$ & 2.50 & 3.00 & 1.07 & 0.30 & -0.44 & 0.37 & \\
\hline $\begin{array}{l}\text { 10. The smallest doubt can stop me from } \\
\text { acting. } \\
\text { Aj najmenšie pochybnosti ma môžu zastavit' } \\
\text { v konaní. }\end{array}$ & 2.40 & 2.00 & 1.10 & 0.49 & -0.44 & & 0.71 \\
\hline $\begin{array}{l}\text { 11. I should be able to organize everything in } \\
\text { advance. } \\
\text { Mal/a by som byt' schopnýlá zorganizovat' } \\
\text { všetko vopred. }\end{array}$ & 3.36 & 3.00 & 1.21 & -0.36 & -0.76 & 0.36 & \\
\hline $\begin{array}{l}\text { 12. I must get away from all uncertain } \\
\text { situations. } \\
\text { Musím uniknút'zo všetkých neistých situácií. }\end{array}$ & 2.68 & 3.00 & 1.21 & 0.26 & -0.75 & & 0.52 \\
\hline
\end{tabular}


Table 2. Descriptive statistics of all variables and correlations with intolerance of uncertainty

\begin{tabular}{|c|c|c|c|c|c|c|c|}
\hline & \multirow[t]{2}{*}{ Mean } & \multirow[t]{2}{*}{ Mdn } & \multirow[t]{2}{*}{ SD } & \multirow{2}{*}{$\begin{array}{c}\text { Cronb. } \\
\alpha\end{array}$} & \multicolumn{3}{|c|}{ Correlations with } \\
\hline & & & & & PA & IA & IU \\
\hline Prospective anx. (PA) & 20.89 & 21.00 & 4.89 & .72 & & $.61^{* * *}$ & $.91^{* * *}$ \\
\hline Inhibitory anx. (IA) & 12.87 & 13.00 & 4.40 & .79 & & & $.87^{* * *}$ \\
\hline Intoler. of uncert. (IU) & 33.75 & 34.00 & 8.34 & .83 & & & \\
\hline \multicolumn{8}{|l|}{ Risk perception } \\
\hline Ethical & 29.59 & 30.00 & 6.79 & .65 & .09 & $.14^{*}$ & .13 \\
\hline Financial & 29.72 & 30.00 & 7.76 & .83 & .03 & .10 & .07 \\
\hline Health/safety & 29.05 & 30.00 & 6.85 & .70 & .12 & $.15^{*}$ & $.15^{*}$ \\
\hline Recreational & 27.81 & 28.00 & 8.21 & .82 & $.20^{* *}$ & $.25^{* * *}$ & $.25^{* * *}$ \\
\hline Social & 18.63 & 18.00 & 6.11 & .68 & $.20^{* *}$ & $.20^{* *}$ & $.23^{* *}$ \\
\hline Total & 134.80 & 135.50 & 26.55 & .89 & $.17^{*}$ & $.23^{* *}$ & $.22^{* *}$ \\
\hline \multicolumn{8}{|l|}{ Risk taking } \\
\hline Ethical & 14.33 & 13.50 & 5.72 & .56 & .04 & .06 & .06 \\
\hline Financial & 14.83 & 13.00 & 7.70 & .80 & -.05 & -.11 & -.09 \\
\hline Health/safety & 21.21 & 22.00 & 7.84 & .67 & .00 & .03 & .01 \\
\hline Recreational & 18.95 & 19.00 & 9.44 & .76 & $-.15^{*}$ & -.13 & $-.16^{*}$ \\
\hline Social & 27.10 & 27.50 & 5.89 & .51 & .02 & -.10 & -.04 \\
\hline Total & 96.42 & 98.00 & 25.78 & .86 & -.06 & -.08 & -.08 \\
\hline Indecisiveness & 20.78 & 20.00 & 6.58 & .81 & .06 & $.39^{* *}$ & $.24^{* *}$ \\
\hline Decision outcomes & -0.13 & -0.13 & 0.10 & - & -.08 & .10 & .01 \\
\hline
\end{tabular}

${ }^{*} \mathrm{p}<.05,{ }^{* *} \mathrm{p}<.01,{ }^{* * *} \mathrm{p}<.001$

\section{Discussion}

This study has presented the Slovak version of the short form of the Intolerance of Uncertainty Scale. A factor analysis has confirmed the two-factor structure of the IUS-12 distinguishing prospective and inhibitory anxiety, which is consistent with the original study. Similarly, the internal consistency of the whole scale and its subscales was in satisfactory interval. The correlations of IU with risk perception, risk taking, indecisiveness and decision outcomes were examined to investigate the construct validity and possible applications of the scale.

The correlation analysis found that risk perception is higher in individuals with higher IU. In other words, people with higher IU perceive risks to be more serious. This was mainly found to be the case in the recreational and social domains. There was a weak correlation in the domain of health/safety which is in line with O'Neill et al. (2006). They reported a similar value $(\mathrm{r}=.11)$ in women endangered by breast cancer. On the other hand, IU was related only to the recreational domain of risk-taking, which indicates that it is manifested more in risk perception than in real risk behaviour. A similar result was found in decision outcomes as another behavioural measure not related to IU.

While the relationships of IU with risk perception and risk taking were not strong and mostly similar for inhibitory and prospective anxiety, this was not found to be the case for associations with indecisiveness. It was not related to anticipatory anxiety, but was associated 
with inhibitory anxiety. This indicates that people may be indecisive not only because they are aware of the uncertainty related to the forthcoming decision, but more because of their fear of the unknown. The reduction of this uncertainty can help them make a decision.

While the present study has brought new information about the associations of IU with selected variables, its results have some limitations in terms of generalizability. The included variables do not represent "classic" variables used in IU research concerning psychopathology and emotional disorders in particular. They are focused more on the manifestations of IU likely to occur in daily situations. On the other hand, this has allowed IU to be used as a predictor of some of the included variables (risk perception, indecisiveness) with a potential role in certain decisions. Despite the given limitations, measuring IU seems to be a useful tool in identifying people able (and not able) to deal with IU. As perceived uncertainty can have the potential to evoke work-related stress, recognizing people with different levels of IU can help find an appropriate position for current or prospective employers. People with higher IU would be more satisfied and useful in positions with more stable and structured work, while individuals more tolerant to uncertainty would fit positions associated with more frequent changes. On the other hand, weak relationships with variables describing behaviour (risk taking, decision outcomes) show that the association with real behaviour are not straightforward and further studies should focus on the role of IU in particular situations.

\section{Literature}

Bavolar, J. (2018). Psychometric characteristics of two forms of the Slovak version of the Indecisiveness Scale. Judgment and Decision Making, 13(3), 287-296.

Blais, A.-R., \& Weber, E. U. (2006). A Domain-specific Risk-taking (DOSPERT) Scale for adult populations. Judgment and Decision Making, 1(1), 33-47. doi: https://doi.org/10.1037/t13084-000

Borchers, J. G. (2005). Accepting uncertainty, assessing risk: Decision quality in managing wildfire, forest resource values, and new technology. Forest Ecology and Management, 211(1-2), 36-46. doi: https://doi.org/10.1016/j.foreco.2005.01.025

Bottesi, G., Noventa, S., Freeston, M. H., \& Ghisi, M. (2019). Seeking certainty about intolerance of uncertainty: Addressing old and new issues through the Intolerance of Uncertainty Scale-Revised. PLOS ONE, 14(2), e0211929. doi:

https://doi.org/10.1371/journal.pone.0211929

Bruine de Bruin, W., Parker, A. M., \& Fischhoff, B. (2007). Individual differences in adult decision-making competence. Journal of Personality and Social Psychology, 92(5), 938956. doi: https://doi.org/10.1037/0022-3514.92.5.938

Carleton, R. N., Norton, M. A. P. J., \& Asmundson, G. J. G. (2007). Fearing the unknown: A short version of the Intolerance of Uncertainty Scale. Journal of Anxiety Disorders, 21(1), 105-117. doi: https://doi.org/10.1016/j.janxdis.2006.03.014 
Clampitt, P., Williams, M. L., \& DeKoch, R. (2007). Embracing uncertainty: The executive's challenge. Journal of Change Management, 2(3), 212-228. doi:

https://doi.org/10.1080/738552753

Ellsberg, D. (1961). Risk, ambiguity, and the Savage axioms. The Quarterly Journal of Economics, 75(4), 643-669. doi: https://doi.org/10.2307/1884324

Flores, A., López, F. J., Vervliet, B., \& Cobos, P. L. (2018). Intolerance of uncertainty as a vulnerability factor for excessive and inflexible avoidance behavior. Behaviour Research and Therapy, 104, 34-43. doi: https://doi.org/10.1016/j.brat.2018.02.008

Freeston, M. H., Rhéaume, J., Letarte, H., Dugas, M. J., \& Ladouceur, R. (1994). Why do people worry? Personality and Individual Differences, 17(6), 791-802. doi: https://doi.org/10.1016/0191-8869(94)90048-5

Gentes, E. L., \& Ruscio, A. M. (2011). A meta-analysis of the relation of intolerance of uncertainty to symptoms of generalized anxiety disorder, major depressive disorder, and obsessive-compulsive disorder. Clinical Psychology Review, 31(6), 923-933. doi: https://doi.org/10.1016/j.cpr.2011.05.001

Grenier, S., Barrette, A.-M., \& Ladouceur, R. (2005). Intolerance of uncertainty and intolerance of ambiguity: Similarities and differences. Personality and Individual Differences, 39(3), 593-600. doi: https://doi.org/10.1016/j.paid.2005.02.014

Innes, S. I., Leboeuf-Yde, C., \& Walker, B. F. (2017). The relationship between intolerance of uncertainty in chiropractic students and their treatment intervention choices. Chiropractic and Manual Therapies, 25(1), 20. doi: https://doi.org/10.1186/s12998-017-0150-2

Kamel, N. F., \& Hashish, E. A. A. (2015). The relationship between psychological need satisfaction, job affective wellbeing and work uncertainty among the academic nursing educators. Journal of Nursing Education and Practice, 5(8), 99-108. doi: https://doi.org/10.5430/jnep.v5n8p99

Kornilova, T. V., Chumakova, M. A., \& Kornilov, S. A. (2018). Tolerance and intolerance for uncertainty as predictors of decision making and risk acceptance in gaming strategies of the Iowa Gambling Task. Psychology in Russia: State of the Art, 11(3), 86-95. https://doi.org/10.11621/pir.2018.0306

Kornilova, T. V., \& Kornilov, S. A. (2010). Intelligence and tolerance/intolerance for uncertainty as predictors of creativity. Psychology in Russia: State of the Art, 3(1), 240256. doi: https://doi.org/10.11621/pir.2010.0012

Ladouceur, R., Gosselin, P., \& Dugas, M. J. (2000). Experimental manipulation of intolerance of uncertainty: a study of a theoretical model of worry. Behaviour Research and Therapy, 38(9), 933-941. doi: https://doi.org/10.1016/S0005-7967(99)00133-3

Lane, M., \& Bocarnea, M. (2011). Uncertainty management's impact on job satisfaction and innovation. Revista de Management Comparat Internațional, 12(1), 97-111.

Lauriola, M., Mosca, O., Trentini, C., Foschi, R., Tambelli, R., \& Carleton, R. N. (2018). The Intolerance of Uncertainty Inventory: Validity and comparison of scoring methods to 
assess individuals screening positive for anxiety and depression. Frontiers in Psychology, 9, 388. doi: https://doi.org/10.3389/fpsyg.2018.00388

Norwood, J. (2018). Psychological uncertainty, stress, frustration and their relationship with counterproductive workplace behavior. Walden Dissertations and Doctoral Studies. Retrieved from: https://scholarworks.waldenu.edu/dissertations/5761

O’Neill, S. C., DeMarco, T., Peshkin, B. N., Rogers, S., Rispoli, J., Brown, K., ... Schwartz, M. D. (2006). Tolerance for uncertainty and perceived risk among women receiving uninformative BRCA1/2 test results. American Journal of Medical Genetics Part C (Seminars in Medical Genetics), 5(2), 251-259. doi: https://doi.org/10.1002/ajmg.c.30104

Ouellet, C., Langlois, F., Provencher, M. D., \& Gosselin, P. (2019). Intolerance of uncertainty and difficulties in emotion regulation: Proposal for an integrative model of generalized anxiety disorder. Revue Européenne de Psychologie Appliquée, 69(1), 9-18. doi: https://doi.org/10.1016/j.erap.2019.01.001

Rosen, N. O., \& Knäuper, B. (2009). A little uncertainty goes a long way: State and trait differences in uncertainty interact to increase information seeking but also increase worry. Health Communication, 24(3), 228-238. doi: https://doi.org/10.1080/10410230902804125

Seely, A. J. E. (2013). Embracing the certainty of uncertainty: Implications for health care and research. Perspectives in Biology and Medicine, 56(1), 65-77. doi: https://doi.org/10.1353/pbm.2013.0009

Shihata, S., McEvoy, P. M., Mullan, B. A., \& Carleton, R. N. (2016). Intolerance of uncertainty in emotional disorders: What uncertainties remain? Journal of Anxiety Disorders, 41, 115-124. doi: https://doi.org/10.1016/j.janxdis.2016.05.001

Williams, M. L., \& Clampitt, P. G. (2003). How employees and organizations manage uncertainty: Norms, implications, and future research. In International Communication Association Conference.

\section{Appendix A}

Correlations of indecisiveness and decision outcomes with risk perception and risk-taking

\begin{tabular}{lcccccc}
\hline & & \multicolumn{5}{c}{ Risk perception } \\
& $\mathrm{E}$ & $\mathrm{F}$ & $\mathrm{H} / \mathrm{S}$ & $\mathrm{R}$ & $\mathrm{S}$ & $\mathrm{T}$ \\
Indecisiveness & .04 & .04 & -.04 & .10 & $.20^{*}$ & .09 \\
Decision outcomes & $.23^{*}$ & .18 & $.32^{* *}$ & $.25^{*}$ & -.08 & $.26^{* *}$ \\
\hline & $\mathrm{E}$ & $\mathrm{F}$ & $\mathrm{H} / \mathrm{S}$ & $\mathrm{R}$ & $\mathrm{S}$ & $\mathrm{T}$ \\
\multirow{2}{*}{ Indecisiveness } & $.22^{*}$ & -.17 & $.33^{* * *}$ & -.03 & $-.26^{* *}$ & .02 \\
Decision outcomes & $-.32^{* *}$ & $-.25^{*}$ & $-.46^{* * *}$ & $-.22^{*}$ & .00 & $-.38^{* * *}$ \\
\hline E- ethical. F- financial, $\mathrm{H} / \mathrm{S}-$ health/safety, $\mathrm{R}-$ recreational, S - social, T-total
\end{tabular}




\section{Corresponding author}

doc. Ing. Mgr. Jozef Bavolar, PhD.

Pavol Jozef Šafárik University in Košice, Faculty of Arts, Department of Psychology Šrobárova 2, 60200 Košice, Slovakia

jozef.bavolar@upjs.sk 


\title{
Engagement in actions beyond basic professional duties - measurement and correlates
}

Agnieszka Bożek ${ }^{1}$ Diana Malinowska ${ }^{1}$ \& Aleksandra Tokarz ${ }^{1}$

${ }^{1}$ Jagiellonian University, Institute of Psychology, Poland

\begin{abstract}
Objective. The main purpose of the paper was to present the construct of engagement in actions beyond basic professional duties (shortly: beyond-duties engagement) and its measurement with the modified version of the UWES-9 questionnaire. An additional goal was to find differences in this type of employee engagement depending on personal variables, and the relationship between it and feedback from others, organizational commitment and burnout.
\end{abstract}

Methods. A preliminary study was conducted within 61 employees (77\% of men) of a mediumsized company in the automatics-robotics industry. In the main study 137 employees (60\% of women) of private and state-owned enterprises of various industries with minimum 2 years work experience in one company took part. In the second study the Feedback scale from the Work Design Questionnaire, Organizational Commitment Scale, and Oldenburg Burnout Inventory were used.

Results. It was found that the modified UWES-9 questionnaire to measure beyond-duties engagement is a one-factor, reliable and theoretically valid measure. The higher level of engagement in actions in leadership positions was established, as well as its positive relationship with feedback from others and organizational commitment, and negative relationship with burnout.

Conclusions. Engagement in actions beyond basic professional duties is a homogenous construct, linked to positive aspects of work. Every employee may engage in additional activities, although working as a manager may be conducive to greater beyond-duties engagement.

Limitations. There was rather small, inhomogeneous group in the main study, in both studies only self-description methods were used.

Keywords. engagement in action; beyond-duties engagement; work engagement; UWES questionnaire

https://doi.org/10.5817/CZ.MUNI.P210-9488-2019-2 


\section{Introduction}

Employee engagement is one of the few constructs that arouses great interest among both scientists and practitioners of work and organizational psychology for almost three decades (Saks \& Gruman, 2014). There are many approaches and definitions of engagement and even names that define the phenomenon itself, e.g.: employee engagement, job engagement (Roberts \& Davenport, 2002) and work engagement (Schaufeli \& Bakker, 2010). Two approaches can be considered as dominant in terms of defining. Historically, Kahn (1990, p. 694) defined engagement first as "the harnessing of organization members' selves to their work roles; in engagement, people employ and express themselves physically, cognitively, and emotionally during role performances". Engagement is also associated with a psychological presence while fulfilling someone's professional role. This concept, however, was rarely used for the first 20 years, as indicated by its few quotations (Saks \& Gruman, 2014). Concepts that contrast the engagement with burnout gained greater popularity. Maslach and colleagues (2001) described engagement as characterized by energy, cooperation and effectiveness, which are the opposition to the three dimensions of burnout. Schaufeli, Salanova, González-Romá and Bakker (2002, p. 74) developed this approach, claiming that engagement is a separate construct defined as a "positive, fulfilling, work-related state of mind characterized by vigor, dedication and absorption". Vigor is characterized by high levels of energy and mental resilience while working, the willingness to invest effort in one's work, and persistence even in the face of difficulties. Dedication is understood as a sense of significance, enthusiasm, inspiration, pride, and challenge. Absorption includes being fully concentrated and deeply engrossed in one's work and having difficulties in detaching oneself from work.

Both approaches to engagement have some common points, although they differ to a large extent. Kahn's concept is more comprehensive because it includes the concept of personal action and agentic self (Cole, Walter, Bedeian \& O'Boyle, 2012), it is also more expressive and unique as it refers to the fusion of the whole person (on physical, emotional and cognitive levels) with their professional role (Saks \& Gruman, 2014). In the approach of Schaufeli and colleagues (2002), although engagement is concerned as a separate construct in relation to other, similar ones, such as job satisfaction or organizational commitment, it is too similar to the concept of burnout as its opposition (Cole et al., 2012; Crawford, LePine \& Rich, 2010), and less comprehensive compared to the Kahn concept. On the other hand, the difficulty in applying the Kahn concept in scientific research is the lack of a universally recognized and satisfactory psychometric tool for measuring such perceived employee involvement, although such attempts have already been made (see Crawford et al., 2010; Soane et al., 2012).

The interest in employees' engagement results from the observations and empirical reports indicating that it contributes to the development of employees, as well as it brings tangible benefits to employing them organizations (Schaufeli \& Salanova, 2008). As shown by Salanova, Del Libano, Llorens \& Schaufeli (2014), engaged employees are characterized by a high level of energy to work, a sense of job satisfaction and a belief that their work is an interesting challenge. They also experience a high sense of control in their work, have sufficient competence to do it well and are attached to the organization. Other authors (e.g. Bakker \& Demerouti, 2008; Schaufeli \& Salanova, 2008) show in their research that engaged employees 
are characterized by better mental health (positive emotionality) and physical health, initiative, proactive behavior and motivation to learn ; they are also more creative, effective and more willing to do things that go beyond basic duties, which is a work challenge. The meta-analysis of correlates of engagement showed that its dimensions are positively linked to job resources, such as social support, autonomy, feedback and self-efficacy; work engagement is also positively related to positive work results, such as commitment to the organization or health status, and negatively to negative work results, such as burnout or the intention to leave work (Halbesleben, 2010). In organizations with engaged employees, financial turnover is increased, staff fluctuation is reduced (especially talented employees) and expenses related to marketing and other management tools are decreased (Szabowska-Walaszczyk, 2010). It should also be pointed out that work engagement is a state much more strongly connected with the results and behaviors of employees in comparison to other similar states, such as job satisfaction or organizational commitment (see: Christian, Garza, \& Slaughter, 2011). Some studies show (e.g. Shukla, Adhikari \& Singh, 2015; Robinson, Hooker \& Hayday, 2007), that employee engagement is connected also with individual variables, like age, gender, education or job role.

The tendency of the engaged employees to undertake additional tasks on their own initiative seems particularly important from the point of view of the employer. As shown in the daily diary studies by Sonnentag (2003), the daily level of employee engagement allows predicting proactive behavior. Other studies have shown that the proactive generation of goals by employees was a strong factor predicting their innovative behaviors in individual work (Odoardi, 2015).

In connection with the above-mentioned findings, it may be important to examine the phenomenon of employee engagement in actions beyond basic professional duties (also known as beyond-duties engagement). Engagement understood in this way concerns the thoughts, emotions and behaviors related to taking action at work on the own initiative of the person and includes activities that do not result from the basic work requirements of the organization in which they are undertaken. Beyond-duties engagement is rather a long-lasting state of mind in which a person undertakes goal-oriented activities and continues them regardless of the difficulties and alternative aspirations encountered.

We were interested in how the engagement in actions beyond basic professional duties is associated with personal variables, like age, gender, education and level of position held, with work resources such as feedback from others, positive states such as organizational commitment and negative states such as burnout. Because there is no method to measure the beyond-duties engagement, it was decided to modify the instructions for the respondents and individual items in the UWES-9 questionnaire (Utrecht Work Engagement Scale) by Schaufeli, Bakker and Salanova (2006), one of the most popular tools to measure work engagement.

As a consequence, the main objective of the undertaken research was to validate the modified version of the UWES-PL-9 questionnaire to measure engagement in actions beyond basic professional duties. An additional goal was to find answers to the following research questions:

1. What are the differences in the scope of engagement in actions beyond basic professional duties of employees depending on personal variables, such as age, gender, 
education, level of position held?

2. What are the links between beyond-duties engagement and feedback from others, organizational commitment and burnout?

\section{Method}

\section{Participants and Procedure}

The research was carried out on-line in two stages. To the preliminary study all employees of one the mid-range company from the automation and robotics industry were invited, from whom 61 employees (77\% of men) aged between 25 and 50 years participated in the study $(\mathrm{M}=37.71, \mathrm{SD}=7.48)$. The majority of them had a Master's degree $(80 \%)$ and held a specialist position (69\%). The invitation along with a link to the questionnaires was sent to the company's HR director, who then sent them to all employees. The main study was conducted among employees of private and state enterprises from various industries, located mainly in southern Poland. The criterion for selection to the group was a minimum two-year work experience in a given company, which seems sufficient for a person to be able to commit to the organization that employs them. The invitation, together with a link to the questionnaires, was sent to various organizations from the researchers' database. 164 people took part in the study, but due to lack of data or failure to meet the criterion, the analysis included 137 employees ( 82 women and $55 \mathrm{men})$ between 23 and 67 years old $(\mathrm{M}=38.25, \mathrm{SD}=10.06)$. The majority of them $(60 \%)$ had a Master's degree, then post-graduate $(18 \%)$, Bachelor's degree $(11 \%)$, secondary education (6\%) and vocational education (5\%). Most of the respondents (48\%) held a specialist position, the remaining managerial (37\%) or administrative (15\%) positions. The seniority of the respondents in the current company ranged between 2 and 31 years $(\mathrm{M}=8.98$, $\mathrm{SD}=6.82)$.

\section{Measures}

In order to measure the dependent variable, a modified version of the UWES Questionnaire (Utrecht Work Engagement Scale) by Schaufeli, Bakker and Salanova (2006) was used in the Polish adaptation of Szabowska-Walaszczyk, Zawadzka and Wojtaś (2011). The scale consists of 9 statements assessed by respondents on the 7-point Likert scale (0 "never", 6 - "always"). The reliability of the Polish version of the UWES, determined by the Cronbach's alpha internal consistency indicator, was .94. In the modified version, the instruction in the manual: The following statements relate to your well-being at work has been replaced: The following statements relate to your well-being when performing activities that go beyond basic professional duties - those that do not result from the basic scope of work responsibilities in your organization. In contrast, in the content of the statements all the words "work", "I work", were replaced by the words "action", "I act." Prior to the research, the intelligibility of the contents of the instructions and items with two psychologists and two nonacademic persons were consulted.

In order to check the psychometric properties of the modified version of the UWES-PL- 
9 questionnaire, the indicators of internal consistency of the questionnaire and the discriminating power of individual items were calculated. The theoretical validity of the tool was verified by means of exploratory and confirmatory factor analysis. In order to obtain answers to the second research questions, the following tools were used:

1. The scale of feedback from others taken from the Work Design Questionnaire (WDQ) by Morgeson and Humphrey (2006) in the Polish adaptation of Malinowska and Tokarz. The scale contains three statements rated by the respondents on the 5-point Likert scale (1 - "I strongly disagree", 5 - "strongly agree"). The Cronbach's alpha internal consistency coefficient for the original scale was .88 . For the needs of the described research, the word "work" was replaced by the word "action".

2. The Organizational Commitment Scale (OCS) by Meyer and Allen (1997) in the Polish adaptation of Bańka, Basińska and Wołowska (2002). The questionnaire consists of 18 items forming three scales: affective commitment, continuance commitment and normative commitment (6 items on each scale). Items are evaluated on a 7-point Likert scale ( 1 - "strongly disagree", 7 - "strongly agree"). In the Polish adaptation of the scale, Cronbach's alpha coefficient for the affective commitment subscale was .84 , for the normative commitment subscale .78, and for the continuance commitment subscale .77 .

3. Oldenburg Burnout Inventory (OLBI) by Demerouti and Bakker (2008) in the Polish adaptation of Baka and Basińska (2016). The questionnaire consists of 16 statements and two 8-item subscales: exhaustion and distance from work. Respondents mark the answers on the 4point Likert scale (1 - "agree"; 4 - "do not agree"). In the Polish adaptation of the scale, Cronbach's alpha coefficient for the exhaustion subscale was 73 , and for the distance from work subscale 69 .

\section{Results}

\section{Factor validity analysis}

In order to verify the factor structure of the questionnaire, in the first step exploratory factor analysis (EFA) with VARIMAX rotation was performed (preliminary study). At the beginning, a scree plot was made, which showed a clearly univariate structure of the modified UWES-9 questionnaire. The 1-factor model was then tested (see Table 1). Factor loads show the dominance of one factor, despite the relatively low load of the ninth item.

In the second step, confirmatory factor analysis (CFA) was performed (main study). The calculations were performed only for the 1-factor model (see Table 2), as it was not possible to estimate data for the 2- and 3-factor model. The obtained values indicate a moderately good fit of the model to the data (RMSEA $=.109, \mathrm{CFI}=.913$, SRMR $=.054)$. Factor loadings are presented in Table 1. The structure obtained is consistent with the validation analysis of the Polish adaptation of the UWES questionnaire. 
Table 1. The loads values of exploratory and confirmatory factor analysis of the modified UWES-9

\begin{tabular}{lcc}
\hline \multicolumn{1}{c}{ UWES-9 items } & $\begin{array}{c}\text { Factor } 1 \\
(\mathrm{EFA}, \mathrm{N} \\
(61)\end{array}$ & $\begin{array}{c}\text { Factor 1 } \\
\text { (CFA, N } \\
=137)\end{array}$ \\
\hline 1. When I act, I feel bursting with energy. & .689 & .698 \\
2. While acting, I feel strong and vigorous. & .756 & .758 \\
3. I am enthusiastic about my actions at work. & .618 & .601 \\
4. My actions inspires me. & .730 & .734 \\
5. When I get up in the morning, I feel like taking & & .713 \\
those actions. & .769 & .777 \\
6. I feel happy when I am acting intensely. & .687 & .692 \\
7. I am proud of the actions that I take. & .624 & .597 \\
8. I am immersed in my actions. & .409 & .410 \\
9. I get carried away when I am acting. & & \\
\hline
\end{tabular}

Table 2. Confirmatory factor analysis coefficients of modified UWES-9

\begin{tabular}{cccccc}
\hline Coefficients & chi $^{2}$ & df & $\begin{array}{c}\text { RMSE } \\
\text { A }\end{array}$ & CFI & SRMR \\
\hline 1-factor model & 71.18 & 27 & .109 & .913 & .054 \\
\hline
\end{tabular}

Note. $N=137, \mathrm{df}$ - degrees of freedom, RMSEA - root means square error of approximation; CFI - comparative fit index; SRMR - standardized root mean square residual; $p<.001$.

\section{External validity analysis}

To assess the theoretical validity of the modified version of the UWES questionnaire, and at the same time to answer the second of the research questions posed, three criteria variables were selected: feedback from others; organizational commitment with its three components: affective commitment, continuance commitment and normative commitment; job burnout with its two components: exhaustion and distance from work. It was expected that engagement in actions beyond basic professional duties would positively correlate with feedback and affective and normative commitment and negatively correlate with continuance commitment and two components of job burnout.

Correlation analysis results confirmed almost all predictions (see Table 3). Significant positive correlations of beyond-duties engagement with feedback from others $(r=.28)$, affective commitment $(\mathrm{r}=.35)$ and normative commitment $(\mathrm{r}=.31)$ and negative correlations with exhaustion $(\mathrm{r}=-.30)$ and distance from work $(\mathrm{r}=-.42)$ were demonstrated. Only the relationship with continuance commitment turned out to be close to zero and insignificant. 
Table 3. Correlations between engagement in actions and related variables

\begin{tabular}{llllllll}
\hline & 1. & 2. & 3. & 4. & 5. & 6. & 7. \\
\hline 1. Engagement in action & - & & & & & & \\
2. Feedback & $.28^{*}$ & - & & & & \\
3. Affective commitment & $.36^{*}$ & .12 & - & & & & \\
4. Continuance commitment & -.06 & -.17 & $.35^{*}$ & - & & & \\
5. Normative commitment & $.31^{*}$ & .04 & $.70^{*}$ & $.24^{*}$ & - & & \\
6. Exhaustion & $-.30^{*}$ & -.12 & $-.23^{*}$ & $.18^{*}$ & $-.25^{*}$ & - & \\
7. Distance from work & $-.42^{*}$ & -.14 & $-.60^{*}$ & -.05 & $-.50^{*}$ & $.33^{*}$ & - \\
\hline
\end{tabular}

Note. ${ }^{*} \mathrm{p}<0.05$

\section{Reliability analysis}

The reliability of the questionnaire was estimated using the internal consistency method, using the Cronbach's alpha coefficient. Statistical analysis (see Table 4) showed that individual items correlated quite high, reaching a total correlation coefficient between .57 and .73, except for the ninth item, whose total correlation coefficient was .38. The discriminating power of individual items was between .85 and .88. Cronbach's alpha coefficient for the entire scale was $.87(\mathrm{~N}=137, \mathrm{M}=37.97, \mathrm{SD}=6.82)$, which indicates a fairly high reliability of the questionnaire.

Table 4. Descriptive statistics and reliability coefficients of UWES-9

\begin{tabular}{|c|c|c|c|c|}
\hline UWES-9 items & M & $\mathrm{S}$ & $\begin{array}{l}\text { Item-total } \\
\text { correlation }\end{array}$ & $\begin{array}{l}\text { Discriminatory } \\
\text { power of items }\end{array}$ \\
\hline 1. When I act, I feel bursting with energy. & 37.68 & 6.14 & .62 & .86 \\
\hline 2. While acting, I feel strong and vigorous. & 36.23 & 6.02 & .70 & .85 \\
\hline $\begin{array}{l}\text { 3. I am enthusiastic about my actions at } \\
\text { work. }\end{array}$ & 38.24 & 6.18 & .58 & .86 \\
\hline 4. My actions inspires me. & 35.68 & 5.97 & .69 & .85 \\
\hline $\begin{array}{l}\text { 5. When I get up in the morning, I feel like } \\
\text { taking those actions. }\end{array}$ & 36.93 & 6.08 & .65 & .85 \\
\hline 6. I feel happy when I am acting intensely. & 35.89 & 5.99 & .73 & .85 \\
\hline 7. I am proud of the actions that I take. & 36.86 & 6.07 & .63 & .85 \\
\hline 8. I am immersed in my actions. & 37.98 & 6.16 & .58 & .86 \\
\hline 9. I get carried away when I am acting. & 37.87 & 6.15 & .38 & .88 \\
\hline
\end{tabular}

In order to obtain the answer to the first research question, the following analyzes were performed: student's t-test for independent groups to determine if there are differences in the dependent variable between women and men; correlation of r-Person in order to find a relation 
between the age of employees and the dependent variable; one-way ANOVA variance analysis, to capture differences in the scope of a dependent variable in employees with different education and occupying positions at different levels.

The research results did not show differences in the level of engagement in actions beyond basic professional duties of people of different ages, different gender and education. Significant differences occurred only in terms of the type of position held $(F(2,134)=5.69, p$ $<.005)$ : managers were characterized by a higher degree of beyond-duties engagement $(\mathrm{MM}=$ 40.72) than specialists ( $\mathrm{MS}=37.0)$ and administrative employees $(\mathrm{MA}=36.5)$.

\section{Discussion}

In this study we analyzed the construct of engagement in actions beyond professional duties which was introduced to capture the employees' motivation to extra-role behaviors. We see it as a psychological gradual process that includes physical-energetic, cognitive and emotional aspects directed towards activities that do not result from the basic work requirements of the organization in which they are undertaken. Thus, our conceptualization differs from previous construct such as proactive behavior, personal initiative and contextual performance which are focused solely on behaviors. Referring to the main objective of the research, which was the validation of a modified version of the UWES-PL-9 questionnaire to measure engagement in actions beyond basic professional duties, it can be concluded that it is a reliable tool. The reliability coefficient was quite high and not much lower than the Polish adaptation of the original version.

Analysis of the factorial validity of the modified UWES-9 questionnaire confirmed its accuracy, although to a limited extent. The obtained one-factor structure is consistent with the Polish adaptation of the original version of this tool, however, it does not coincide with the Dutch version of the questionnaire (Schaufeli et al., 2006), the level of matching the one-factor model to the data is also weak. The results obtained can be explained in two ways. Firstly, a number of previous studies carried out in different countries did not confirm the three-fold structure of the UWES questionnaire: sometimes it was one factor, sometimes two (Mills, Culbertson \& Fullagar, 2012). This may be due to cultural differences reflected in a different approach to work in the Netherlands and other Western countries, and Eastern European countries where one goes to work primarily because of economic reasons, and proactivity is not necessarily a value. Secondly, the research group in the main study was very diverse. The respondents shared only a minimum of two years of professional experience, but differed in age (23-67 years), actual professional experience (between 2 and 31 years), type and size of enterprise (state or private), and industry. Considering the differences in the experience of these people, one can presume that their understanding of activities that go beyond basic professional duties may be different, consequently it can have impact on the difficulties to obtain the original factor structure. Thus, it is worth to carry out further research with a modified version of the UWES-9 questionnaire on more homogenous group.

Referring to the first research question, the research results showed that there are no significant differences in the scope of beyond-duties engagement of employees depending on 
personal variables such as age, gender and education. Differences appeared only in the type of position held; for managers this level was significantly higher. This may lead to the conclusion that rather non-personal variables are responsible for the variance of results, e.g. characteristics of the working environment. It can be also concluded that personal benefits resulting from engaging in additional activities at work are achievable at every stage of professional life, although working as a manager may be conducive to greater engagement in the undertaken activities. This issue can be explained in two ways. First, the work of the manager is associated with greater opportunities for self-fulfillment, as it requires the possession and use of more competences (Deci \& Ryan, 2000). Secondly, having responsibility and control naturally increases motivation to work (Gick \& Tarczyńska, 1999).

While answering the second research question, it turned out that beyond-duties engagement is positively related to affective and normative organizational commitment and received feedback from others and negatively with burnout dimensions. The results obtained show that people who are more engaged beyond their duties are also more emotionally and normatively committed to their organization, and vice versa, due to the correlation nature of the analyzed relationship. Considering the lack of a statistically significant correlation with continuance commitment, these results show that employees engaged in actions beyond basic professional duties are optimally committed to their organization. Employees with a high level of engagement in actions beyond basic professional duties have a positive attitude towards the organization employing them. The basis of their commitment is not the inability to find another job, but the emotional bond with the organization and its members, and the desire to work in it because of a sense of commitment. The result regarding the positive relationship between feedback from others and the analyzed construct can be interpreted in relation to the function of this resource at work. Similarly to the work engagement (Bakker, 2011), it can act as a stimulus for beyond-duties engagement. On the other hand, a positive correlation between engagement in actions beyond basic professional duties and feedback may indicate that such employees may themselves look for information on the quality of their work. Other research (see Baka \& Basińska, 2016) confirm the negative relationship of work engagement and burnout. It can therefore be assumed that this should be similar to the beyond-duties engagement. This relationship also indicates that people engaged in additional activities do not feel overloaded with their duties, and that the difficulties they encounter at work may be treated by them more as challenges than obstacles on the path of their professional development. On this basis, it is possible to conclude about better professional adaptation and personal functioning of people with a high level of engagement in actions beyond basic professional duties.

In addition to their strengths, the research also has its weaknesses. Only two crosssectional studies were performed on relatively small groups of employees, using only selfdescription methods. In the future, it would be worth repeating the research on larger, more homogeneous groups of employees, using also objective data on the effectiveness of employees engaged beyond their duties. It would also be interesting to check the relationship of engagement in actions beyond professional duties with other job demands and resources. 


\section{Literature}

Baka, Ł., \& Basińska A. K. (2016). Psychometryczne właściwości polskiej wersji Oldenburskiego Kwestionariusza Wypalenia Zawodowego (OLBI) [Psychometric features of the Polish version of the Oldenburg Burnout Inventory]. Medycyna Pracy, 67(1), 29-41. https://doi.org/10.13075/mp.5893.00353

Bakker, A. B. (2011). An evidence-based model of work engagement. Current Directions in Psychological Science, 20(4), 265-269. http://doi.org/10.1177/0963721411414534

Bakker A. B., \& Demerouti, E. (2008). Towards a model of work engagement. Career Development International, 13(3), 209-223. http://doi.org/10.1108/13620430810870476

Bańka A., Basińska R., \& Wołowska A. (2002). Polska wersja Meyera i Allen Skali Przywiązania do Organizacji [The Polish version of Meyer's and Allen's Organizational Commitment Scale]. Czasopismo Psychologiczne, 8(1), 65-74.

Christian, M., Garza, A., \& Slaughter, J. (2011). Work Engagement: A quantitative review and test of its relations with task and contextual performance. Personnel Psychology, 64(1), 89-136. http://doi.org/10.1111/j.1744-6570.2010.01203.x

Cole, M. S., Walter, F., Bedeian, A. G., \& O’Boyle, E. H. (2012). Job burnout and employee engagement: A meta-analytic examination of construct proliferation. Journal of Management, 38(5), 1550-1581. http://doi.org/10.1177/0149206311415252

Crawford, E. R., LePine, J. A. \& Rich, B. L. (2010). Linking job demands and resources to employee engagement and burnout: A theoretical extension and meta-analytic test. Journal of Applied Psychology, 95(5), 834-848. http://doi.org/10.1037/a0019364

Deci, E. L., \& Ryan, R. M. (2000). The "what" and "why" of goal pursuits: Human needs and the self-determination of behavior. Psychological Inquiry, 11, 227-268. http://doi.org/10.1207/S15327965PLI1104 01

Demerouti, E., \& Bakker, A. B. (2008). The Oldenburg Burnout Inventory: A good alternative to measure burnout and engagement. In J. Halbesleben (Eds.), Handbook of stress and burnout in health care (pp. 65-78). New York, NY: Nova Science.

Gick, A., \& Tarczyńska M. (1999). Motywowanie pracowników: systemy, techniki, praktyka [Motivating employees: systems, techniques, and practice]. Warszawa: Polskie Wydawnictwo Ekonomiczne.

Halbesleben, J. R. B. (2010). A meta-analysis of work engagement: Relationships with burnout, demands, resources and consequences. In A. B. Bakker \& M. P. Leiter (Eds.), Work engagement: The essential in theory and research (pp. 102-117). New York: Psychology Press.

Kahn W. A. (1990). Psychological condition of personal engagement and disengagement at work. Academy of Management Journal, 33(4), 692-724. http://doi.org/10.2307/256287

Maslach, C., Schaufeli, W. B., \& Leiter, M. P. (2001). Job Burnout. Annual Review of Psychology, 52, 397-422. http://doi.org/10.1146/annurev.psych.52.1.397 
Meyer, J. P., \& Allen, N. J. (1997). Commitment in the workplace: Theory, research, and application. Thousand Oaks: Sage.

Mills M. J., Culbertson S. S., \& Fullagar C. J. (2012). Conceptualizing and Measuring Engagement: An Analysis of the Utrecht Work Engagement Scale. Journal of Happiness Studies, 13(3), 519-545. http://doi.org/10.1007/s10902-011-9277-3

Morgeson, F. P. \& Humphrey, S. E. (2006). The Work Design Questionnaire (WDQ): developing and validating a comprehensive measure for assessing job design and the nature of work. Journal of Applied Psychology, 91(6), 1321-1339. 10.1037/00219010.91.6.1321.

Odoardi, C. (2015). The relationship between proactive goal generation and innovative behaviour at work. Journal of Management Development, 34(5), 553-565. http://doi.org/10.1108/JMD-04-2014-0037

Roberts, D. R. \& Davenport, T. O. (2002). Job engagement: Why it's important and how to improve it. Employment Relations Today, 29, 1-29. http://doi.org/10.1002/ert.10048

Robinson, D., Hooker, H., \& Hayday, S. (2007). Engagement: The continuing story. Institute for Employment Studies. Retrieved from: https://www.employmentstudies.co.uk/system/files/resources/files/447.pdf

Saks A. M. \& Gruman J. A. (2014). What do we really know about employee engagement? Human Resources Development Quarterly, 25(2), 155-182. http://doi.org/10.1002/hrdq.21187

Salanova M., Del Libano M., Llorens S., \& Schaufeli W. B. (2014). Engaged, workaholic, burned-out or just 9-to-5? Toward a typology of employee well-being. Stress \& Health, 30(1), 71-81. http://doi.org/10.1002/smi.2499

Schaufeli, W. B. \& Bakker, A. B. (2010). Defining and measurement of work engagement. In A. B. Bakker \& M. P. Leiter (Eds.) Work engagement: A handbook of essential theory and research (pp. 10-23). New York: Psychology Press.

Schaufeli W. B., Bakker A. B., \& Salanova M. (2006). The measurement of work engagement with a short questionnaire: A cross-national study. Educational and Psychological Measurement, 66(4), 701-716. http://doi.org/10.1177/0013164405282471

Schaufeli, W. B. \& Salanova, M. (2008). Enhancing work engagement through the management of human resources. In K. Näswall, M. Sverke \& J. Hellgren (Eds.) The individual in the changing working life (pp. 380-402). Cambridge: Cambrigde University Press.

Schaufeli, W. B., Salanova, M., González-Romá, V., \& Bakker, A. B. (2002). The measurement of engagement and burnout: A confirmative analytic approach. Journal of Happiness Studies, 3, 71-92. http://doi.org/10.1023/A:1015630930326

Shukla, S., Adhikari, B., \& Singh, V. (2015). Employee Engagement-Role of Demographic Variables and Personality Factors. Amity Global HRM Review, 5, 65-73. 
Soane, E., Truss, C., Alfes, K., Shantz, A., Rees, C., \& Gatenby, M. (2012). Development and application of a new measure of employee engagement: The ISA Engagement Scale.

Human Resources Development International, 15(5), 529-547.

http://doi.org/10.1080/13678868.2012.726542

Sonnentag S. (2003). Recovery, work engagement, and proactive behavior: A new look at the interface between nonwork and work. Journal of Applied Psychology, 88(3), 518-528.

http://doi.org/10.1037/0021-9010.88.3.518

Szabowska-Walaszczyk A. (2010). Zaangażowanie w pracy i organizacji - przegląd problematyki i narzędzi pomiaru [Engagement in work and organization - an overview of problems and measurement tools]. In A. M. Zawadzka (Eds.). Psychologia zarzadzania w organizacji, (pp. 143-169). Warszawa: Wydawnictwo Naukowe PWN.

Szabowska-Wlaszczyk A., Zawadzka A. M., \& Wojtaś M. (2011). Zaangażowanie w pracę i jego korelaty: adaptacja skali UWES autorstwa Schaufeliego i Bakkera [Work engagement and its correlates: adaptation of the UWES scale by Schaufeli and Bakker]. Psychologia Jakości Życia, 10(1), 57-74.

\section{Corresponding author}

Mgr. Agnieszka Bożek

Jagiellonian University, Institute of Psychology

Ingardena 6, 30-060 Krakow, Poland

agnieszka.bozek@doctoral.uj.edu.pl 


\title{
Starting an entrepreneurial career: Young entrepreneurs' profiles.
}

Denisa Fedákovál \& Zuzana Kožárová ${ }^{2}$

${ }^{1}$ Centre of Social and Psychological Sciences, Slovak Academy of Sciences, Slovakia

${ }^{2}$ University Councelling Center, Pavol Jozef Šafarik University, Slovakia

\begin{abstract}
Objective. The first aim of this paper is to identify the important features of five entrepreneurial career categories: reasons for pursuing entrepreneurship, preparing for entrepreneurship, launch of entrepreneurship, risks and family background. The second aim of the paper is to describe the profiles of young entrepreneurs using the five entrepreneurial career categories.

Method. An 80-minute focus group session with 7 young entrepreneurs aged 26 to 30 years led by 2 moderators. The discussion focused on launching the business and its subsequent development. The discussion was audio recorded and transcribed. The transcripts were processed using Atlas.ti software.
\end{abstract}

Results. The qualitative content analysis of the transcriptions revealed the building blocks of the five entrepreneurial career categories. Seven entrepreneur profiles were created. The findings show various elements and factors affect decisions about entrepreneurial careers.

Conclusions. The paper contributes to knowledge relating to the content of the five categories, and specifically to beginning an entrepreneurial career. The individual profiles of the young entrepreneurs reveal the diversity, peculiarities and similarities of the beginnings of an entrepreneurial career. The aim behind the young entrepreneur profiles is to provide effective stimuli for university students attending career planning courses.

Limitations. The findings presented here are based on a single focus group discussion, and so cannot be generalized. The size and composition of the focus group (age, gender and region) could be considered a limitation, or conversely as a strength.

Keywords. Young entrepreneurs; career beginnings; individual career profiles; focus group.

https://doi.org/10.5817/CZ.MUNI.P210-9488-2019-3 


\section{Introduction}

In our paper, consistent with many authors, we study and describe the career path using a developmental-contextual approach: this approach involves investigating a certain developmental period (young adulthood) and graduation and how these interact with many different factors and impacts (socio-demographic, personal, interpersonal, external etc.) (Akosah-Twumasi et al., 2018; Schoon \& Duckworth, 2012; Aldrich \& Kim, 2007).

The results of a British study indicate that young people are influenced by personal experiences from their youth when making future career decisions, such as experience of a family business (Schoon \& Duckworth, 2012). In Slovakia this factor is much less common since the parents of today's young entrepreneurs are more likely to have been employees than entrepreneurs.

There are various reasons for embarking upon an entrepreneurial career. The entrepreneurs in a study by Carter et al. (2003) gave six reasons for setting up their own business: innovation, independence, financial success, a task/role model, self-fulfilment and recognition Pilková et al. (2017) listed other factors shaping decision-making about entrepreneurial pathways: demographic characteristics, individual characteristics (perceived business opportunities and fear of failure), resources (human, social and financial capital) and environmental factors. In our study, we were interested not just in the reasons for embarking on entrepreneurship, but also in the beginnings and subsequent progress of the business, the associated risks and family background. The focus groups were crucial to obtaining a picture of the young entrepreneurs' experiences of launching a business. We were specifically interested in young entrepreneurs in eastern Slovakia, where the labour market and conditions for starting a business differ from in western Slovakia (Report on the Business Environment in the Slovak Republic, 2018). In the east, entrepreneurship represents an alternative to selfemployment as there is a shortage of high-qualified jobs. The aim of the paper is twofold:

1. To identify the typical features of the beginnings of the entrepreneurial path

2. To outline the career profiles of young entrepreneurs

\section{Method}

The sample consisted of seven young entrepreneurs (men aged 26 to 30) engaged in different types of businesses. Two had completed secondary school education and five had a master's degree. The entrepreneurs were contacted personally or online, and selected in accordance with their availability and willingness to participate in the research. They participated in an 80-minute focus group led by two moderators. The focus group centred around the topic of entrepreneurship. It began with the participants being informed about the aims of the research, and the duration and discussion themes to be covered in the focus group. They were also told about opportunities to learn more about the research results and our findings. In order to achieve the first aim, we conducted a literature study to identify the five categories of factors that play a role at the beginning of an entrepreneurial career: reason for embarking on entrepreneurship, preparing for entrepreneurship, entrepreneurial beginnings, risks and family background. Firstly, we were interested in why they had decided to start their 
own business. We investigated this by asking an introductory question: "Why (did you) decide to pursue an entrepreneurial career?" The remaining questions were based on the factors presented by Pilková et al. (2017) (Table 1).

Table 1. Process of formulating the questions relating to the pre-defined factors and categories

\begin{tabular}{|c|c|c|}
\hline $\begin{array}{l}\text { Factors playing a role at } \\
\text { beginning } \\
\text { entrepreneurship }\end{array}$ & Category & Question \\
\hline \multirow{2}{*}{$\begin{array}{l}\text { Individual characteristics } \\
\text { (perceived entrepreneurial } \\
\text { opportunities and fear of } \\
\text { failure) }\end{array}$} & Preparing for entrepreneurship & $\begin{array}{l}\text { How did you come up with the } \\
\text { business idea/opportunity? }\end{array}$ \\
\hline & Risks & Do entrepreneurs take risks? \\
\hline $\begin{array}{l}\text { Resources } \\
\text { financial capital) }\end{array}$ & Entrepreneurial beginnings & $\begin{array}{l}\text { How did you get from idea to } \\
\text { activity? }\end{array}$ \\
\hline Environmental factors & Family background & $\begin{array}{c}\text { Family and entrepreneurship? } \\
\text { Family support? Parents' } \\
\text { attitudes? }\end{array}$ \\
\hline
\end{tabular}

Having obtained the participants' consent, the focus group discussion was recorded, transcribed and processed using Atlas.ti software. To improve the objectivity of the results, the text material was subjected to two independent analyses. The theoretical approach used in the qualitative analysis was analytical deduction. The categories were derived from the theoretical background (Plichtová, 1996). We began with five pre-defined and theory-driven categories (reasons for entrepreneurship, preparing for entrepreneurship, entrepreneurial beginnings, risks and family environment) that come up repeatedly in the literature describing entrepreneurial beginnings. We then examined the two independent analyses in order to identify the most relevant content pertaining to the categories. The content was then categorized to reflect agreement between the analyses of the two assessors (authors).

\section{Results}

To achieve the first aim of the study, we defined five theory-driven categories based on the literature study. Those categories are: the reason for entrepreneurship, preparation for the business, start of the career, risks and the family background. The findings indicated that the categories were filled/saturated with the mutual interaction of many factors and impacts. The content of the individual categories is presented in Table 2, including selected quotes.

The second aim of the study was to outline the career profiles of the young entrepreneurs. Seven profiles of young entrepreneurs are presented below. They cover the five categories (reasons for entrepreneurship, preparing for entrepreneurship, career launch, risks and family background). The names of the profiles reflect specific features of the young entrepreneurs. 
Table 2. Features of the beginnings of young people's entrepreneurial pathways in five predefined categories

Category 1: Reasons for embarking on entrepreneurship

Building the foundations

Opportunity to stay in Slovakia

Parents had their own business

Not being an employee

Self-development/Self realization

To create values

Pleasure

No restrictions

The need for autonomy and flexibility

Seizing the opportunity

Solving situations

Finance
"Get ready for bigger things."

"Create space for better things that I will enjoy."

"My own business was a way I could stay in Slovakia."

"I have never seen anything else at home."

"I didn't want to be an employee."

"...anything but sitting in an office"

"...to progress, to develop in some way, for me and the company."

"I want to hand over values to people."

"I enjoy it!"

"I can see no limits."

"There are no limits, that's why I have my own business."

"It was the only way I could devote my time to the sports club I'm in charge of."

"I wanted to be in control of my time."

"There was an opportunity and I wanted to seize it. That's it. I didn't have any other reasons."

“...the person is looking for something they can't find, that's why they go into business."

"I needed to pay my bills."

\footnotetext{
Category 2: Preparing for entrepreneurship

In the family

Looking for the opportunity

Inspiring stories

Studying the theory

With a coach

Getting the contacts

"I have the know-how from my father..."

“...what's the gap in this particular field in Slovakia ..."

“...in my case, reading a book, a business story of a similar person or a similar company or the field I'm working in worked very well. There's much more."

"There are courses on the theory. I did course XXX. They teach you all the different aspects in a general sense. You can learn it."

"I found a coach who's had his own business all his life. He taught me the drive and the skills and I started gaining lots of abilities."

"...most of the contacts I have, are from my family."; “..I met new people..."
} 
During my studies

Getting to know oneself

Keeping your eyes open

Getting the starting capital
"...I studied machinery and $3 D$ design and I discovered it could be used in the family production."

"...first I told myself what I could do, what I was good at or even better at than other people..."

"I got the idea abroad, as I travelled a lot and saw new cultures, met new people, I observed my surroundings so I had what's known as an open mind-set."

"It's a reasonable amount of money which I'll be able to pay back doing an ordinary job."

\begin{tabular}{|c|c|}
\hline \multicolumn{2}{|c|}{ Category 3: Starting the business } \\
\hline Take action & "To target the first customers and tell them what I can do." \\
\hline I do what I like & “... I want to do this." \\
\hline Listening to (the customers) & $\begin{array}{l}\text { "You have to listen to the customers, to the other side. } \\
\text { Because this is something not everybody is willing to do." }\end{array}$ \\
\hline Being aware of the environment & $\begin{array}{l}\text { "To see the market, to see the market situation, to see more } \\
\text { than the others." }\end{array}$ \\
\hline Perspective & "...this is not the only thing." \\
\hline With someone & $\begin{array}{l}\text { “...with my brother..”; “..with a good friend”; “...with my } \\
\text { parents/father...” }\end{array}$ \\
\hline \multicolumn{2}{|r|}{ Category 4: Risks } \\
\hline Financial loss & $\begin{array}{l}\text { "It's common. I mean the financial risks, especially with the } \\
\text { initial investment." }\end{array}$ \\
\hline Loss of motivation & $\begin{array}{l}\text { "I'm lacking the motivation to try it again and again and } \\
\text { again ..." }\end{array}$ \\
\hline Always present & “...the risks are daily." \\
\hline Innovative & $\begin{array}{l}\text { "When someone stops coming up with new ideas and has } \\
\text { been doing one thing for a long time, in a few years' time } \\
\text { they may not be in business anymore." }\end{array}$ \\
\hline Unpredictable situations & "Someone may decide to ruin you." \\
\hline Minimizing the risks & $\begin{array}{l}\text { "A businessman tries to manage the risks, to make them } \\
\text { smaller, have a smaller impact." }\end{array}$ \\
\hline Other losses & "You could lose the client." \\
\hline
\end{tabular}

\section{Category 5: Parents - Family background}

Business experience

"My parents have their own business"; "I've seen it since I was a child."

No business experience

"No one in our family has business experience."

Supporting

"Every parent wants to support their child."

Ironic

“... so I was told: I knew you wouldn't work it out." 
Initial scepticism

Discouraging, careful, protective

Different generation

Good upbringing/responsibility
"My mum asked me: When are you going to get a normal job?"

"I was discouraged from going into it full on..."; "At first, my parents didn't want either me or my brother to set up a business."

"Our parents grew up in an era when having your own business was forbidden."

"To me, this is the basic principle of having your own business. I'm very responsible when it comes to paying invoices. I see the person, the other entrepreneur on the other side who needs money to pay for his business, too."

PROFILE 1 (ADAPTIVE CREATOR) (aged 28, university degree, jewellery making)

This young entrepreneur's reasons for going into business were quite clear from childhood as his family ran their own business. Life and business were just obviously connected "I'd never seen anything else at home. I took it as being quite natural." He wanted to bring something of his own into the family business so he introduced the technological knowledge he had gained at university into the business. He is continuing the family business using innovative methods that link his studies with the business opportunity. He started his career using his creative approach "Business ideas are everywhere". He feels confident and established and so is not worried about the risks "You get over them more easily when you start a business at a young age". When discussing the family business he said he would prefer a non-family business "If I could choose, I would never go into business with my parents or with other family members".

PROFILE 2 (DISSATISFIED DAREDEVIL) (aged 30, university degree, food imports)

This entrepreneur did not come from an entrepreneurial background. He decided to go into business having experienced working for companies. His reasons were clear. He disliked being employed in companies and wanted to achieve something for himself. "I was dissatisfied with my career and was looking for opportunities to change". He identified these when travelling abroad. The idea came to him and he started making preparations to go into business. He and a friend had a plan so they did some market research, identified a gap in the market and seized the opportunity.

When he and his friend began their entrepreneurial career, they had no experience, "we made a rough calculation" never to be entirely happy with anything on principle.

"We said to ourselves, let's go for it! We had a specific goal we wanted to achieve and we set out the timeframe within which we wanted to achieve it." He had no idea what the potential risks might be: "it was difficult to estimate. You sometimes do things without thinking and take the bull by the horns but that's what you have to do when running a business." As there were no entrepreneurial roots in his family, DD's parents were sceptical but he thought that was a good thing “... we always listen to our parents, as they look at it all from another 
perspective."

PROFILE 3 (UNLIMITED OPTIMIZER) (aged 28, secondary education, runs a clothing shop)

The reason this entrepreneur went into business was that he couldn't make decisions in the jobs he did. He tried a number of jobs but was unhappy and terribly bored, "I could only do what I was told, it was holding me back and I couldn't make any progress". He decided to run his own business because "...there are no limits”. When preparing to go into business he was guided by two things: 1) his own strengths (what I'm good at) and 2) what was lacking in Slovakia. Despite launching a successful career, he sees it as temporary solution "... to me, it's not what I want to do forever." He is a risk optimizer, "I didn't invest much money into the business". He is cautious about risks: "There are always risks, you never know what might happen...". Nobody in his family had run a business so his family held negative views about his entrepreneurial decisions, "... they held me back, told me not to go the whole way, as it would end in bankruptcy for sure and I would be left with nothing...", they had no confidence in the idea, "If I had done it as I wanted, it would be 30-40\% better now."

PROFILE 4 (PERSUASIVE VALUE CREATOR) (aged 30, university degree, training and education)

This young man opted for an entrepreneurial career because he lacked flexibility in his former job. He did not want to be limited by rigid working hours: "I didn't like the eight to four routine." When preparing to launch his own business, he looked for a gap in the market that would enable him to make full use of his potential and experience "the things that worked for me, I started to sell on". He went from idea to activity. "I targeted my first customers and told them what I could do". At the start of his career, his aim was to create values for customers. So he listened carefully to his customers explanations of their requirements and then thought about how he could improve their training, "I literally tried to read between lines when talking with customers". He is aware of the risks and so he advises them to keep their eyes open, "financial risks can appear very quickly". His father had run a business for a short time but it was unsuccessful and this negative experience remained with the family. His mother pushed him to get a "normal job": "she saw that I had created and written something, I was in a hurry to achieve something she didn't understand and so she tried to stop me. But I felt it was because she was trying to protect me."

PROFILE 5 (ADAPTIVE IMPLEMENTER) (aged 30, university degree, construction project manager)

The reasons this young man became an entrepreneur were obvious: he wanted to be in control of his own time and to escape from a corporate way of working that he strongly disliked. When preparing to go into business, he looked at his father's career and the opportunities in the family business, "I capitalized on the know-how around me". He reassessed the possibilities 
and joined his father, "my father clearly supported me, he shares his experience and contacts with me. My mother keeps asking me when will I get a normal job." While launching his entrepreneurial career, he was wondering how he could bring innovation into his father's wellestablished business. He is well aware the risks are always there, the financial ones especially, but other risks too: "you can lose your name, status and even your health when you fail."

PROFILE 6 (RESILIENT PREDICTOR) (aged 26, university degree, drinks manufacturer)

This young man's pathway into entrepreneurship opened up once he had identified the opportunity: "there was an opportunity and I wanted to seize it." My studies and time spent abroad had enhanced my entrepreneurial activities: "I started my business while I was a university student, six months before graduating". He emphasized his "open-minded" approach to everyday life. He thinks there are many opportunities around; you just have to spot them. He patiently followed his dream and did not allow other people to distract him from it. He and his brother shared the work on the final stage of the preparations for launching the business: "I am in charge of the marketing and my brother is responsible for production. We help each other; he does one part and I do the other." Risks present themselves everyday: "an entrepreneur is a kind of psychopath, as he is willingly to risk his own money, time and part of his personal life. Something could happen at any time." He talks of "acceptable risk": "The price wasn't that high, so if it hadn't worked, I wouldn't have had huge regrets." Nobody in the family had been in business. His parents did not want their sons to run their own business at the beginning, but... "... when they realized they couldn't talk us out of going into business, they began supporting us and they still do". All in all, the business made us join forces as a family: "I run the business together with my brother."

PROFILE 7 (GOAL ORIENTED SELLER OF IDEAS) (aged 27, secondary education/university studies not completed, soft skills trainer)

This young man decided to become an entrepreneur because he sought financial independence and personal autonomy. He began preparing to go into business when at university. He discovered he had the drive to create his own career trajectory: "I was developing more skills and competences and I immediately put these into practice". At the start of his career, he was very active in contacting potential clients and offering his services: "selling the idea was my main activity." He was prepared to accept risks. He mentions innovative risk as a serious threat: "When an entrepreneur stops coming up with new ideas, he/she may go bankrupt sooner or later." His family has no business background and his parents were sceptical about his career at the beginning but are now supportive: "... I was told: Oh, I didn't think you would succeed, and of course it was a challenge for me and strong motivation for me to achieve."

\section{Discussion}

This study and the findings presented here contribute to what we know about the processes and background to the entrepreneurial beginnings of young people. The analyses of 
the material show that young people's decisions about entrepreneurship are influenced by many factors. In addition to well-known factors such as the potential for self-realization, autonomy and family influence (Pilková et al., 2017), our findings suggest that entrepreneurship presented young, competent people with a means of staying in Slovakia, and in their home region. The local market in Slovakia is not saturated, and so it is easier to find business opportunities (gaps in the market) and there is less competition among SMEs. The responses of the young entrepreneurs suggest that travelling and seeking inspiration abroad are one way of discovering business opportunities. Environmental factors and the influence of the family are often discussed in the literature (Schoon \& Duckworth, 2012). Entrepreneurial parents usually play an influential role, but supportive parents with no business experience can act as good models by displaying useful competencies through good attitudes to work. Moreover, our findings show that entrepreneurship strengthens communication and family relationships.

The participants of our focus group demonstrated that they had the courage to take the first step and set up their own business and the willingness to share their experiences. The research findings provide valuable insights that we were subsequently able to draw on when creating a training programme for university students called "Do something!", on developing entrepreneurial skills (Kožárová, 2018; Kožárová \& Fedáková, 2018). We expect that these real-life profiles of young entrepreneurs who launched their careers while still at university will encourage other students embarking on their career path. There is potential for business universities to focus on developing competencies and to provide a "contact environment" in which students can gain their first business experience (Salem, 2014). More than $50 \%$ of graduates do not work in the field they studied (Trexima, 2019). Entrepreneurship could therefore present an alternative means of self-assertion while preventing brain drain.

The limitations of our study are the small research sample, the fact that all the participants were men within a single age category from one region in Slovakia. However, group homogeneity can also be considered a strength in qualitative analysis. In the future, we are planning to carry out a study with female entrepreneurs. Comparing different age categories when investigating the start of the career path could also enrich the research. The outputs of the content analysis may serve as a basis for measuring the entrepreneurial start.

\section{Literature}

Aldrich, H.E., \& Kim, P.H. (2007). Small worlds, infinite possibilities? How social networks affect entrepreneurial team formation and search. Strategic Entrepreneurship Journal, 1, 147-165. http://doi.org/10.1002/sej.8

Akosah-Twumasi, P., Emeto, T. I., Lindsay, D., Tsey, K., \& Malau-Aduli, B. S. (2018). A Systematic Review of Factors That Influence Youths Career Choices - the Role of Culture. Frontiers in education, 3, 1-15. http://doi.org/10.3389/feduc.2018.00058

Carter, N. M., Gartner, W. B., Shaver, K. G., \& Gatewood, E. J. (2003). The career reasons of nascent entrepreneurs. Journal of Business Venturing, 18(1), 13-39. http://doi.org/10.1016/S0883-9026(02)00078-2 
Kožárová, Z., \& Fedáková, D. (2018). Študenti a podnikatelia. Ich pohl'ady na podnikanie. In P. Kačmár, J. Bavol'ár, \& L.Lovaš (Eds.) Proceedings from the $17^{\text {th }}$ Conference Psychológia práce a organizácie 2018 (pp. 252-265). Košice, Filozofická fakulta UPJŠ.

Gielnik, M. M., Zacher, H., \& Wang, M. (2018). Age in the entrepreneurial process: The role of future time perspective and prior entrepreneurial experience. Journal of Applied Psychology, 103(10), 1067-1085. http://doi.org/10.1037/apl0000322

Kožárová, Z. (2018). PODNIKNI NIEČO! (Popis tréningového programu na rozvoj podnikavosti a kariérovej adaptability). Kariérové poradenstvo v teórii a praxi, 14, 43-49.

Pilková, A., Holienka, M., Rehák, J., Kovačičová, Z., Komorník, J., Mitková, L., Mikuš, J., Letovanec, M., Smoroňová, T., \& Klimáček, P. (2017). Inkluzivita podnikania na Slovensku: stav a vývojové tendencie. Univerzita Komenského v Bratislave: KARTPRINT.

Plichtová, J. (1996). Obsahová analýza a jej možnosti využitia v psychológii. Československá psychologie, 40(4), 304-314.

Report on the Business Environment in the Slovak Republic. Správa o stave podnikatel'ského prostredia v Slovenskej republike. (2018). Dostupné z: https://www.mhsr.sk/uploads/files/tj29ai10.pdf

Salem, M. I. (2014). Higher education as a pathway to entrepreneurship. The International Business \& Economics Research Journal, 13(2), 289-294. http://doi.org/10.19030/iber.v13i2.8443

Schoon, I., \& Duckworth, K. (2012). Who becomes an entrepreneur? Early life experiences as predictors of entrepreneurship. Developmental psychology, 48(6), 1719-1726. http://doi.org/10.1037/a0029168

TREXIMA. (2019). Trendy práce. Accessible online:

Nezamestnanost'absolventov: https://rendyprace.sk/uploads/absolventi/PDF sktrendy nez amestnanost.pdf

\section{Corresponding author}

Mgr. Denisa Fedáková, Ph.D.

Centrum spoločenských a psychologických vied SAV

Karpatská 5, 04001 Košice, Slovakia

dfedak@saske.sk

Grantová podpora: Paper was supported by scientific grant agency VEGA 2/0118/17. 


\title{
The effect of manager's frequency and quality of communication on team's performance
}

\author{
Michal Franc ${ }^{l}$, Radvan Bahbouh ${ }^{1,2} \&$ Rudolf Kubik ${ }^{1}$ \\ ${ }^{1}$ QED GROUP a.s. \\ ${ }^{2}$ Charles University, Faculty of Arts, Department of Psychology, Czech Republic
}

\begin{abstract}
Objective. This paper wants to empirically test hypothesis that team leader's (who is the strongest determinant of communication climate and shared mental models within the team) higher frequency and quality of communication leads to higher performance.

Method. Hypothesis was tested on a sample of 237 leaders of sales teams from a large financial institution. The team leaders were rated based on quality and frequency of their communication by their subordinates. Team leaders had to be in their positions at least for 1 year. Standard sociomapping items with previously demonstrated reliability and validity were used to measure communication. Team performance was measured by average team member's annual revenue.

Results. Regression analysis showed positive effect of quality and frequency of team leader's communication on team performance.

Conclusions. From theoretical perspective, the paper follows up on studies investigating relationship between communication satisfaction and team performance. Practical implications lie mainly in s interventions and other efforts to improve communication within organizations. Further, it highlights the necessity to consider managers' communicationrelated competencies during their selection and consecutive development.
\end{abstract}

Limitations. The main limitations of this study are its cross-sectional character and specificity of the sample (effect of intervening variables such as company culture cannot be excluded).

Keywords. team leader; quality of communication; frequency of communication; team performance; sociomapping

https://doi.org/10.5817/CZ.MUNI.P210-9488-2019-4 


\section{Introduction}

Work teams are a group of people striving to achieve a shared goal. In order to act collectively, team members have to coordinate their actions. This coordination necessitates mutual communication of individual team members (Marks, Mathieu, \& Zaccaro, 2001). This highlights that the team's ability to achieve shared goals should be dependent on frequency and quality of mutual communication between individual team members (Marlow, Lacerenza, Paoletti, Burke, \& Salas, 2018) where particularly the team leader's communication should play a crucial role (Marks, Mathieu, et al., 2001). However, scientific investigation of this topic provided mixed results (Bahbouh, 2012; Leenders, Engelen, \& Kratzer, 2003).

The first reason for these mixed findings could be that not all communication between the team members has to be instrumental toward accomplishing the shared team task. In fact, even though communication about personal topics can promote trust within the team, it can also serve as a distraction from working on the shared team task (De Dreu, 2008).

Second, the stage of development of the team or the stability of its environment may come into play. As we described earlier, communication is crucial when individual team members need to coordinate in their shared goal pursuit. However, after certain experience with the task, all team members develop a good cognitive representation of how to coordinate; i.e., good shared mental models and transactive memory systems are present, and high frequency of communication can be redundant or even a hindrance while working on the team task (Edwards, Day, Arthur Jr., \& Bell, 2006; Lewis, 2004; Marks, Sabella, Burke, \& Zaccaro, 2002).

In addition to these concerns, there are also frequent caveats to team performance measures. Researchers have either been working with team's performance in some artificial tasks in lab settings, which leads to questions about generalizability of such findings (e.g., Marks, Mathieu, et al., 2001), or actual field data about performance are used, where there could be any number of intervening variables between the effect of frequency and quality of communication on team's performance, such as business cycle or dependency on other external factors (Kendall \& Salas, 2004).

\section{Sociomapping and communication research}

Sociomapping is a process that allows for an analysis and depiction of team communication. It uses a set of standard relational scales whose outputs are visualized in the form of sociomap, which is a graph depicting communication patterns within the team using landscape metaphor for more intuitive reading (Bahbouh, 2012). Sociomapping has been used for investigation of team communication since HUBES (Human Behavior in Extended Spaceflight) high fidelity spaceflight simulation experiment in 1994 and consecutively in EKOPSY (1995-1996), Mars 105 (2009), Mars 500 (2010-2011) and Sirius 2017 (Bahbouh, 2012).

The importance of communication has been emphasized by cosmonauts themselves. Especially a conflict between two crew members, which led to premature termination of space mission or the first recorded space strike leading to cutting off of the control center from the 
space crew. In addition, even SPHINX 1999 high fidelity space flight simulation had to be terminated due to conflicts within crew. Nowadays, the relationship between communication and team performance (or its failure) of space crew a well-established fact (Kanas \& Manzey, 2008; Landon, Vessey, \& Barrett, 2016).

Similar picture can be drawn from aircraft crew setting, where communication failures presented the most frequent reason for air crashes in the 90es, with estimates from 70 to $80 \%$ (Lauber, 1987; Tajima, 2004).

Nevertheless, aircraft accidents are an extreme example of team failures. It is much harder to estimate failures in common work teams. Some sources estimate that $50 \%$ of work team failures are due to suboptimal communication (Brent \& Dent, 2017). In common work teams, we can expect similar relationship between communication and performance, which nevertheless presents some difficulties with operationalization of team performance. Extensive meta-analysis of 72 studies compiling information about almost 5000 teams showed relationship between communication, information sharing, and performance (Mesmer-Magnus \& Dechurch, 2009). This relationship is collaborated by other studies (Becerra \& Gupta, 2003; Hirokawa, 1980). Nevertheless, some other studies identified inversed "U" relationship between communication and performance, where too much communication can hinder team performance (Leenders et al., 2003; Smith, Olian, Sims, \& O’Bannon, 1994).

\section{Role of team leader's communication}

Previous research has shown that among all team members, team leader's communication is critical in all stages of team's task work. Team leader is frequently the source of information about the task, especially in organizational setting, where leader represents and disseminates information from the organization to the team as well as communicates on team's behalf with the organization (Fleishman et al., 1991). Indeed, previous research has shown that team leaders' communication is crucial for team members shared mental models and transactive memory systems (Marks, Zaccaro, \& Mathieu, 2001) and that team leaders' communication is perceived as more important and team members communicate with them more frequently as compared to other team members (Bahbouh, 2014). Team leaders also play key role in creating team climate. (Dragoni \& Kuenzi, 2012). As such, we expect that quality and frequency of team leaders' communication will be positively related to team performance, where quality of team leader's communication is defined as an extent to which it is clear, complete and timely (González-Romá \& Hernández, 2014; Rozehnalová, 2013).

\section{Method}

\section{Sample}

Data about frequency and quality of communication from 237 managers of sales teams from a large financial institution was collected. The data collection was a part of more complex development center program. The inclusion criteria were that the managers had to be in their position for at least one year. After consenting to participate on the development center 
program, subordinates of each manager were contacted to fill in measures of frequency and quality of their communication with the particular team members. The average size of the team was 9.679 (median $=9, S D=4.245$ ), team size ranging from 3 to 26 with average response rate $67.7 \%$.

\section{Measures}

Communication measures. Standard sociomapping questions for measuring frequency and quality of communication were used (Bahbouh, 2012; Rozehnalová, 2013). Frequency of communication was measured by "How often does your superior communicate with you about work-related matters?" statement, which was rated on 5-point scale (1 - almost never, 5 almost all the time). Similarly, quality of communication was measured by "Rate your superior's quality of communication in terms of its content and timeliness" statement, which was rated on 5-point scale ( 1 - could often be higher, 5 - often above average). These scales showed to have high test-retest reliability (mean $r=.798$ ) and validity (e.g., correlation between current frequency of communication and estimation of time spent together was $r=.781$; for more information see Bahbouh, Rozehnalová, \& Děchtěrenko, 2013; Rozehnalová, 2013).

Table 1. Descriptive statistics for variables of interest

\begin{tabular}{lccccc}
\hline & $N$ & Minimum & Maximum & $M$ & $S D$ \\
\hline Communication frequency & 237 & 2.267 & 5 & 4.247 & 0.502 \\
Quality of communication & 237 & 1.8 & 5 & 3.844 & 0.583 \\
$\begin{array}{l}\text { Team size } \\
\begin{array}{l}\text { Average team member's } \\
\text { annual revenue }\end{array}\end{array}$ & 237 & 3 & 26 & 9.679 & 4.245 \\
\end{tabular}

Note. * Approximately 1800 EUR.

Ratings of manager's frequency ( $\mathrm{r}_{\mathrm{WG}}$ mean $=0.8, S D=0.17$, median $=0.85$ ) and quality $\left(\mathrm{r}_{\mathrm{WG}}\right.$ mean $=0.75, S D=0.13$, median $\left.=0.77\right)$ of communication showed sufficient withingroup agreement (cf. LeBreton \& Senter, 2008) to justify their aggregation to team-level means, consistent with direct-consensus model (Chan, 1998; Kozlowski \& Klein, 2000). For descriptive statistics, refer to Table 1.

Team performance. Team performance was measured by average team member's annual revenue in CZK. Due to the sensitive nature of this information this variable was meancentered for the purposes of this paper $(S D=45610.831)$, see Table 1. for details. 
Table 2. Correlations of variables of interest

\begin{tabular}{|c|c|c|c|c|c|}
\hline & & $\begin{array}{l}\text { Frequency of } \\
\text { communication }\end{array}$ & $\begin{array}{l}\text { Quality of } \\
\text { communication }\end{array}$ & $\begin{array}{l}\text { Team } \\
\text { size }\end{array}$ & $\begin{array}{l}\text { Average team } \\
\text { member's annual } \\
\text { revenue }\end{array}$ \\
\hline $\begin{array}{l}\text { Frequency } \\
\text { communication }\end{array}$ & of & 1 & $0.625^{* *}$ & $-0.287 * *$ & $0.185 * *$ \\
\hline $\begin{array}{l}\text { Quality } \\
\text { communication }\end{array}$ & of & $0.625^{* *}$ & 1 & -0.105 & $0.196^{* *}$ \\
\hline Team size & & $-0.287 * *$ & -0.105 & 1 & -0.011 \\
\hline $\begin{array}{l}\text { Average } \\
\text { member's } \\
\text { revenue }\end{array}$ & $\begin{array}{r}\text { team } \\
\text { annual }\end{array}$ & $0.185^{* *}$ & $0.196^{* *}$ & -0.011 & 1 \\
\hline
\end{tabular}

\section{Results}

To test our predictions about the relationship between manager's communication and team's performance, we conducted linear regression analysis. Previous research showed that frequency of communication is affected by team size (Vraný \& Bahbouh, 2014) and indeed, even in our sample there was a significant correlation between team size and frequency of communication, refer to Table 2. Therefore, we always first entered team size as a control variable into the model. In the first tested regression model, entering Frequency of manager's communication explained $3.6 \%$ in average team member's annual revenue and this change in $\mathrm{R}^{2}$ was significant, $F(1,234)=8.774, p=0.003^{1}$. The relationship between manager's frequency of communication and team performance was positive $(b=18027.777, p=0.003)$, refer to Table 3.

Table 3. Regression of communication on team performance.

\begin{tabular}{llccccc}
\hline \multicolumn{1}{c}{ Model } & $\beta$ & $b$ & $S E$ & $t$ & $p$ \\
\hline $1 \quad$ (Constant) & & 1120.330 & 7404.392 & 0.151 & 0.880 \\
& Team size & -0.011 & -115.745 & 700.785 & -0.165 & 0.869 \\
\hline & (Constant) & & -81370.080 & 28785.285 & -2.827 & 0.005 \\
2 & $\begin{array}{l}\text { Team size } \\
\text { Frequency }\end{array}$ & 0.046 & 496.997 & 719.836 & 0.690 & 0.491 \\
& communication & & 18027.777 & 6086.058 & 2.962 & 0.003 \\
\hline & (Constant) & 0.198 & & & & \\
3 & Team size & & -60404.236 & 21351.011 & -2.829 & 0.005 \\
& Quality of communication & 0.198 & 15445.814 & 5039.389 & 3.065 & 0.002 \\
\hline
\end{tabular}

Note. Dependent Variable: Average team member's annual revenue

\footnotetext{
${ }^{1} \mathrm{R}^{2}$ of the whole model was $.036, F(2,234)=4.401, p=.013$.
} 
In the second tested model, entering Quality of manager's communication explained $3.9 \%$ in average team member's annual revenue and this change in $\mathrm{R}^{2}$ was significant, $F(1$, $234)=9.394, p=0.003^{2}$. Quality of manager's communication was also positively related to team performance $(b=15445.814, p=0.002)$.

\section{Discussion}

Our findings about the positive effect of manager's frequency and quality of communication on team performance have several important implications. First, this study replicates previous findings from lab setting, where team leader's briefs improved team's performance, especially in novel environments (Marks, Zaccaro, et al., 2001). It does so in field setting using long-term teams with real-life team performance measures (Kendall \& Salas, 2004). On the first glance, the effect size of standardized regression coefficients seems relatively small. However, considering the number of potential intervening variables that can influence the processes that lead from team leader's communication characteristics to his or her team's objective performance in terms of its sales (i.e., the sources of error, see MesmerMagnus \& Dechurch, 2009 for more information) and the practical real-world effect as described by unstandardized regression coefficients (i.e., the actual change in team's sales based on changes in team leader's communication characteristics), the effect size seems to be relatively strong (cf. Kelley \& Preacher, 2012). Manager's ability to communicate effectively and to be in touch with his or her team showed to be a significant predictor of team performance and as such it should be the focus of training interventions for emerging leaders and communication-related competences should be considered during team-leader selection process.

However - and perhaps more importantly - the current study presents evidence for validity of established communication measurement scales used in sociomapping (Bahbouh, 2012; Rozehnalová, 2013). These seem to be able to capture managers' key behaviors that are necessary for effective regulation of team processes that are essential for team performance.

This study has certain limitations. For example, its cross-sectional character should reflect in certain caution when making claims about causality between our variables of interest. Future studies should map the relationship between trends in manager's communication and team performance over time. In addition, data from one organization were collected, which means that we cannot exclude the potential effect of intervening variables, such as organizational culture. As such, it would be desirable to replicate current finding on a more varied sample. Similarly, information about the size of a branch and size of settlement where the team resided was not available. Future studies account for these intervening variables in order to make the team performance more comparable.

Future studies should also investigate the factors that influence perceived quality of

\footnotetext{
${ }^{2} \mathrm{R}^{2}$ of the whole model was $.039, \mathrm{~F}(2,234)=4.711, p=.010$.
} 
manager's communication. Our sociomapping scale serves as a starting point for interventions and as such it is designed to capture as wide scope of problems as possible so it can start the corrective process. Future studies should use more nuanced models of manager's communication so the effect of different aspects of communication behavior can be compared in their effect on team functioning and performance. In addition, it should be investigated, how quality of team leader's communication influences quality of communication within the whole team. Previous research on similar population showed that communication quality as a team level concept is a good predictor of team-level performance (González-Romá \& Hernández, 2014) and there is a growing body of evidence suggesting that team leaders are strong determinants of team climate and other team level concepts (Dragoni \& Kuenzi, 2012). Sociomapping tool can be a great source of insight into these processes.

\section{Literature}

Bahbouh, R. (2012). Sociomapping of Teams. Praha: Dar Ibn Rushd \& QED GROUP.

Bahbouh, R. (2014). Proof of sociomapping validity based on team position. In R. Bahbouh \& G. Lasker (Eds.), Sociodiagnostics and sociomapping (Vol. 3, pp. 24-28). Canada: The International Institute for Advanced Studies in Systems Research and Cybernetics.

Bahbouh, R., Rozehnalová, E., \& Děchtěrenko, F. (2013). Dependability of group communication sociomapping. In R. Bahbouh \& G. Lasker (Eds.), Sociodiagnostics and sociomapping (Vol. 2, pp. 29-33). Canada: The International Institute for Advanced Studies in Systems Research and Cybernetics.

Becerra, M., \& Gupta, A. (2003). Perceived Trustworthiness Within the Organization: The Moderating Impact of Communication Frequency on Trustor and Trustee Effects. Organization Science, 14, 32-44. https://doi.org/10.1287/orsc.14.1.32.12815

Brent, M., \& Dent, F. E. (2017). The Leadership of Teams: How to Develop and Inspire High-performance Teamwork (UK ed. edition). London; New York: Bloomsbury Business.

Chan, D. (1998). Functional relations among constructs in the same content domain at different levels of analysis: A typology of composition models. Journal of Applied Psychology, 83, 234-246. https://doi.org/10.1037/0021-9010.83.2.234

De Dreu, C. K. W. (2008). The virtue and vice of workplace conflict: Food for (pessimistic) thought. Journal of Organizational Behavior, 29(1), 5-18. https://doi.org/10.1002/job.474

Dragoni, L., \& Kuenzi, M. (2012). Better understanding work unit goal orientation: Its emergence and impact under different types of work unit structure. Journal of Applied Psychology, 97(5), 1032-1048. https://doi.org/10.1037/a0028405

Edwards, B. D., Day, E. A., Arthur Jr., W., \& Bell, S. T. (2006). Relationships among team ability composition, team mental models, and team performance. Journal of Applied Psychology, 91(3), 727-736. https://doi.org/10.1037/0021-9010.91.3.727 
Fleishman, E. A., Mumford, M. D., Zaccaro, S. J., Levin, K. Y., Korotkin, A. L., \& Hein, M. B. (1991). Taxonomic efforts in the description of leader behavior: A synthesis and functional interpretation. The Leadership Quarterly, 2(4), 245-287. https://doi.org/10.1016/1048-9843(91)90016-U

González-Romá, V., \& Hernández, A. (2014). Climate uniformity: Its influence on team communication quality, task conflict, and team performance. Journal of Applied Psychology, 99(6), 1042-1058. https://doi.org/10.1037/a0037868

Hirokawa, R. Y. (1980). A comparative analysis of communication patterns within effective and ineffective decision-making groups. Communications Monographs, 47(4), 312-321. https://doi.org/10.1080/03637758009376040

Kanas, N., \& Manzey, D. (2008). Basic issues of human adaptation to space flight. In Space psychology and psychiatry (pp. 15-48). Springer. https://doi.org/10.1007/978-1-4020$\underline{6770-9} 2$

Kelley, K., \& Preacher, K. J. (2012). On effect size. Psychological Methods, 17(2), 137-152. https://doi.org/10.1037/a0028086

Kendall, D. L., \& Salas, E. (2004). Measuring team performance: Review of current methods and con-sideration of future needs. In J. W. Ness, V. Tepe, \& D. R. Ritzer (Eds.), The Science and Simulation of Human Performance (pp. 307-326). https://doi.org/10.1016/S1479-3601(04)05006-4

Kozlowski, S. W. J., \& Klein, K. J. (2000). A multilevel approach to theory and research in organizations: Contextual, temporal, and emergent processes. In K. J. Klein \& S. W. J. Kozlowski (Eds.), Multilevel theory, research, and methods in organizations: Foundations, extensions, and new directions (pp. 3-90). San Francisco, CA: Jossey-Bass.

Landon, L. B., Vessey, W. B., \& Barrett, J. D. (2016). Evidence report: Risk of performance and behavioral health decrements due to inadequate cooperation, coordination, communication, and psychosocial adaptation within a team.

Lauber, J. K. (1987). Human factors and aircraft accidents. 1987 Australian Aviation Symposium: 'Innovate or Enervate'; The Preprints of Papers, 245. Institution of Engineers, Australia.

LeBreton, J. M., \& Senter, J. L. (2008). Answers to 20 questions about interrater reliability and interrater agreement. Organizational Research Methods, 11(4), 815-852. https://doi.org/10.1177/1094428106296642

Leenders, R., Engelen, J., \& Kratzer, J. (2003). Virtuality, communication, and new product team creativity: A social network perspective. Journal of Engineering and Technology Management, 20, 69-92. https://doi.org/10.1016/S0923-4748(03)00005-5

Lewis, K. (2004). Knowledge and performance in knowledge-worker teams: A longitudinal study of transactive memory systems. Management Science, 50, 1519-1533.

https://doi.org/10.1287/mnsc.1040.0257 
Marks, M. A., Mathieu, J. E., \& Zaccaro, S. J. (2001). A temporally based framework and taxonomy of team processes. Academy of Management Review, 26(3), 356-376. https://doi.org/10.5465/AMR.2001.4845785

Marks, M. A., Sabella, M., Burke, S., \& Zaccaro, S. (2002). The impact of cross-training on team effectiveness. The Journal of Applied Psychology, 87, 3-13. https://doi.org/10.1037//0021-9010.87.1.3

Marks, M. A., Zaccaro, S., \& Mathieu, J. (2001). Performance implications of leader briefings and team-interaction training for team adaptation to novel environments. The Journal of Applied Psychology, 85, 971-986. https://doi.org/10.1037/0021-9010.85.6.971

Marlow, S. L., Lacerenza, C. N., Paoletti, J., Burke, C. S., \& Salas, E. (2018). Does team communication represent a one-size-fits-all approach? A meta-analysis of team communication and performance. Organizational Behavior and Human Decision Processes, 144, 145-170. https://doi.org/10.1016/j.obhdp.2017.08.001

Mesmer-Magnus, J., \& Dechurch, L. (2009). Information sharing and team performance: A meta-analysis. The Journal of Applied Psychology, 94, 535-546. https://doi.org/10.1037/a0013773

Rozehnalová, E. (2013). Reliability and validity of communication sociomapping (Doctoral dissertation). Charles University, Prague, Czech Republic.

Smith, K., Olian, J., Sims, H., \& O’Bannon, D. (1994). Top management team demography and process: The role of social integration and communication. Administrative Science Quarterly, 39. https://doi.org/10.2307/2393297

Tajima, A. (2004). Fatal miscommunication: English in aviation safety. World Englishes, 23(3), 451-470. https://doi.org/10.1111/j.0883-2919.2004.00368.x

Vraný, M., \& Bahbouh, R. (2014). Relating team size and communication patterns in work teams. In R. Bahbouh \& G. Lasker (Eds.), Sociodiagnostics and sociomapping (Vol. 3, pp. 29-33). Canada: The International Institute for Advanced Studies in Systems Research and Cybernetics.

\section{Corresponding author}

Michal Franc

QED GROUP a.s.

Štěpánská 20, Praha 1, Czech Republic

michal.franc@qedgroup.cz 


\title{
Replication of psychometric analysis of the 4Elements Inventory (4EI) in the general population
}

Eva Höschlová ${ }^{1,2}$, Radvan Bahbouh ${ }^{1,2}$

${ }^{1}$ Charles University, Faculty of Arts, Department of Psychology, Czech Republic

${ }^{2}$ QED GROUP, a.s., Czech Republic

\begin{abstract}
Objective. The 4EI questionnaire, based on a four-factor personality model derived from the metaphor of the four elements, was standardized in 2008 in the form of a 100-item version on a quota representative Czech sample (N=493), after ten years of prior development. Following that, it was also standardized based on quota representative samples in the US and Spain. In 2018, the psychometric analysis of 4EI was replicated on a sample of the general population (GP).
\end{abstract}

Method. The GP sample was comprised of all those who filled out the questionnaire since the aforementioned standardization ( $N=13$ 298, 58.5\% females, average age 36.7, SD=9.7). A basic descriptive statistics item analysis, correlational analysis of the four elements (dimensions), as well as reliability measures and exploratory factor analysis were all repeated on this sample and compared with the previous analyses' results.

Results. In both samples, the difficulty of all items ranged between .1 and .9 and all items correlated with corresponding scales at least 2 or stronger. All four elements (dimensions) reached a high reliability, comparable with the previous estimations. The EFA of a priori fourfactor structure showed results comparable to those of the analysis performed ten years ago. Factor scores as outputs from EFA highly correlate with raw scores of four measured elements (from 96 to .71).

Conclusions. Our study provides support for the psychometric qualities of the 4EI questionnaire, even using the new, extended GP sample.

Limitations. The EFA as an exploratory tool provides sufficient evidence neither for the stability of factor structure in time nor for the factor validity. Therefore, there is a new article about 4EI in progress, where the results of CFA and ESEM will be provided.

Keywords. Personality; 4 elements inventory; reliability; validity

https://doi.org/10.5817/CZ.MUNI.P210-9488-2019-5 


\section{Introduction}

The search for the basic elements that are latent in the background of diversity and variety, started the philosophy itself in the 6th century BC. For more than two thousand years it has been widely accepted that these are four basic elements - water, fire, air, and earth (Ball, 2004; Rupp, 2005). Aristotle combined four elements with the four basic polarity characteristics wet-dry and hot-cold (Ball, 2004), continuing the Hippocratic tradition, which, by changing the ratio of elements (and their properties), explained differences in human behavior and disease incidence (Hippocrates, 1881). This way of thinking has for long predetermined not only the perception of the outside world, but also the linguistic and thought metaphors in which people considered the inner world, that is, personality differences. This can be seen in the long-term use and extension of the speculative conceptions of the four basic temperaments that many philosophers, psychologists, and physiologists have returned over the centuries (Matthews, Deary, \& Whiteman, 2003; Chamoro-Premuzic, 2014). Given that factor analysis offers multiple factor models of personality, we wondered whether the two-and-a-half thousand-yearold speculative metaphor of the four elements was psychometrically supported. In the affirmative, we were interested in the relationship of a four-factor personality model to the fivefactor Big Five model, which can be understood as an integrative and generally accepted personality model that has dominated the number of publications over the past decades (De Raad, 2009; John, Naumann, \& Soto, 2008). Moreover, we also wanted to explore relations of the four-element personality model to the psychobiological concept of the four-factor temperament described as a part of TCI-R by Cloninger (1999), as this model of personality has had considerable influence within psychiatry and psychology during the last 20 years (Farmer \& Goldberg, 2008).

The first step in addressing this issue was to determine whether people were considering similar characteristics with the individual elements. We first addressed this question through in-depth interviews, in which we tried to inquire in detail about the behavior and characteristics of people that the interviewees would select as typical representatives of a particular element (Bahbouh et al., 2006). For the lexical characteristics that we obtained through this qualitative research, we then found on another sample whether people tend to associate them with one element more strongly than with another. These quantitative data were supplemented by the results of the semantic differential of the individual elements (Abramčuk, 2009). This material was used to create a pool of items that were repeatedly tested in different assemblies.

4EI has been in development since 2003 and underwent several standardizations and psychometric analyses in the following five years (Bahbouh et al., 2006, Fajmonová \& Bahbouh, 2008; Rozehnalova \& Bahbouh, 2010, Bahbouh et al., 2012), throughout which the current 100 items were consecutively selected from originally over 400 items. The 5 th version of 4EI questionnaire was standardized on a quota representative Czech sample $(\mathrm{N}=493)$ in 2008 in the form of a 100-item version (Rozehnalova \& Bahbouh 2010). Considering the number of respondents, exploratory factor analysis was carried out to reveal the latent structure of the questionnaire. Since the highest factor saturation found for individual items was in line with the assumption of their elemental assignment, four factors were named by elements. The questionnaire also showed very satisfactory psychometric characteristics (Bahbouh et al, 2012). 
The test has been used most frequently in workshops and self-development programs. The main reason for this application area was the fact that the metaphor of the four elements unlike many other technical terms - is well (and similarly) understandable. The agreement of people on the elements' attributes is due not only to the fact that the elements have generally known physical characteristics but also to the fact that they are used extensively in metaphors describing human behavior. For instance, we say that someone is "down to earth", "having a heated argument", "has their head in the clouds", "is drowning in emotion" and so on. The advantage of the 4EI is that it does not consider the elements as categories or types to which people are assigned, but as four dimensions that we all have developed to a certain extent. None of the elementary dimensions is perceived as clearly positive or negative. We consider it advantageous that the concept of personality description, which has been part of the linguistic and cultural tradition of many nations for more than 2,500 years, can be easily and psychometrically soundly operationalized in a simple and psychometrically healthy manner without a significant shift from the common understanding of the elements.

During the ten years, it was possible to gather various proofs of validity. The construct validity of the 4EI was subsequently analyzed in a series of studies focused on convergent and discriminant validity. For example, the correlation with EPQ-R or NEO-FF-I (Abramčuk, 2011), NEO-PI-R (Hochel, Fajmonová, Rozehnalová, \& Bahbouh, 2011; Bahbouh et al., 2012), MBTI and HPI (Rozehnalova \& Bahbouh, 2010) and Cloninger's TCI-R (Řežábková, 2018). Table 1 and Table 2 show some of the results, more can be found in the original literature and in the manual of the 5th version of 4EI which is currently in print (Bahbouh \& Höschlová, in print).

Table 1. Correlations of NEO-PI-R scales and 4EI scales, N=342 (Bahbouh, Rozehnalová, Fajmonová, \& Sněhotová, 2012, p. 24)

\begin{tabular}{lccccc}
\hline & $\mathrm{N}$ & $\mathrm{E}$ & $\mathrm{O}$ & $\mathrm{A}$ & $\mathrm{C}$ \\
\hline Air & .10 & .45 & .29 & -.19 & -.30 \\
Earth & -.02 & -.12 & -.35 & -.05 & .69 \\
Fire & -.15 & .56 & .14 & -.28 & .08 \\
Water & .62 & -.40 & .04 & -.01 & .26 \\
\hline
\end{tabular}


Table 2. Correlations of TCI-R scales and 4EI scales, $N=51$ (Řežábková, 2018, p. 77)

\begin{tabular}{lcccc}
\hline & HA & NS & RD & PS \\
\hline Air & -.55 & .73 & .22 & .03 \\
Earth & .11 & -.64 & -.31 & .50 \\
Fire & -.74 & .51 & -.08 & .45 \\
Water & .69 & -.33 & .32 & -.47 \\
\hline
\end{tabular}

$\mathrm{HA}=$ harm avoidance, $\mathrm{NS}=$ novelty seeking, $\mathrm{RD}=$ reward dependence, $\mathrm{PS}=$ persistence

As a part of contrast validity research, several authors studied the differences in the representation of individual element scores among various types of professions (Fajmonová, Bahbouh, Rozehnalová, \& Hochel, 2011), or specific professions such as athletes (Frainšicová, 2013), managers (Koldová, 2014), or professional soldiers (Břeň \& Heřman, 2019).

More than 13000 respondents have been tested by the Czech version of the questionnaire over the last ten years. This scope allowed us to perform a confirmatory factor analysis and compare it with the results of a CFA of other personality tests (to be published as part of another study being prepared). At the same time, it offered us an interesting opportunity to repeat after ten years the same exploratory analysis procedure used in 2008 , thereby obtaining and comparing all psychometric data in a replication study, the procedure and results of which are now summarized here.

\section{Method}

\section{Sample description}

The general population sample (referred to under the acronym GP) includes all those who filled out the 4EI questionnaire between 2011 and 2018; in total 13298 respondents $(58.5 \%$ female, $41.5 \%$ male, average age $36.7, S D=9.7)$. The majority of the sample is formed by employees of medium to large companies in a productive age between 25 and 45 who took part in talent programs, leadership programs or other personal development programs whose part was the 4EI diagnostic. Other respondents in the sample wanted to fill out the 4EI questionnaire out of personal interest and self-development reasons.

This GP sample will further be compared to the Czech standardization sample, which was collected in 2008 based on quota criteria (age, gender and education), such that it would be quota representative of the Czech population. This sample (referred to under the acronym CZ) included 493 people ( $49.1 \%$ female, $50.9 \%$ male). 


\section{EI Description}

The $5^{\text {th }}$ version of 4EI consists of 100 items, and the score of each element trait is always comprised of a sum of 25 items. The 100 statements are all rated on the same three-point scale: I agree, I cannot decide, I disagree.

The inventory was constructed exclusively as a development instrument for the adult working population. Most frequently, it is used by members of top management, higher and middle management, lower management and team leaders, specialists, administrative workers and university students.

The study of test-retest reliability from 2013 on the sample of 123 people showed reasonably stable results even after longer period of time. The average correlation of two measures after three months was .83 (Air: $r=.85$; Earth $r=.82$; Fire: $r=.89$; Water $r=.77$ ) and after 9 months .79 (Air: $r=.81$; Earth $r=.84$; Fire: $r=.82$; Water $r=.68$ ). A thorough description of the study and its detailed results are available in the 4EI manual (Bahbouh \& Höschlová, in print).

Internal consistency of individual element scales measured by McDonald's Omega $(\mathrm{N}=13$ 298) shows convincing results for all elements: Air: $\omega=.78$; Earth: $\omega=.81$, Fire: $\omega=$ .88 , Water: $\omega=.82$. Cronbach's $\alpha$ coefficients and Guttman's split-half coefficients are reported in this paper's results below, nevertheless they show very similar values as Omega.

The available language versions are Czech, English and Spanish. For the English version, norms are available from 2010, and a new data collection is presently ongoing based on a quota representative sample of the US population. Norms from 2010 are also available for the Spanish version, obtained from a quota representative sample of the Spanish population.

\section{Data analysis}

To describe the raw scores (RSs) of the four elements, standard descriptive statistics were calculated. A comparison of the means of the RSs of elements between the GP and CZ samples was performed using a t-test, to calculate the correlation coefficient among the RSs of the elements, the Pearson correlation coefficient was used. Considering the high number of cases in both samples and no extreme deviations from the normal distribution (skewness, kurtosis), parametric methods seemed to be appropriate.

In order to confirm the reliability, both samples' internal consistency was analyzed using Cronbach's $\alpha$ coefficient, and the split-half reliability was verified using the Guttman's coefficient for unequal length, given that each of the 4 element scores is comprised of 25 items.

The construct validity study, namely the examining of the four-factor structure of the 4EI questionnaire, was performed using exploratory factor analysis; for the extraction method, the principal axis factoring method was used with the Varimax rotation. We decided on the exploratory approach for two reasons. Firstly, we wanted to understand whether the search for four mutually non-correlated factors in the 100-item 4EI data would lead to a solution whose derived factor scores would correspond to the RSs of the element scales. Besides, given the sample size, the number of items and the resulting scales of the questionnaire using a 
confirmatory factor analysis would not have been suitable for the $\mathrm{CZ}$ sample. In this replication study, we thus focused on comparing the results while maintaining the same exploratory approach and FA methods as used in 2008 for the standardization sample CZ.

All analyses were conducted using the statistical software SPSS 25.0.

\section{Results}

\section{Description of the raw scores (RSs) of the main scales and their comparison}

The basic descriptive characteristics of the four RSs corresponding to the four main scales of 4EI are shown in Table 3. The mean of the Air scale did not differ in a statistically significant way in the observed samples, despite the large size of sample GP, $t(13789)=0.51$, $p=.614)$. In the subsequent two scales, we observed statistically significant differences, which, however, had a very low effect size value: Earth, $t(13789)=3.04, p=.002, d=0.14$; Fire, $t(13789)=3.28, p=.001 ; d=0.15$. In both cases, the average value of the Earth and Fire scales was larger for the GP sample than it was for the CZ sample. A different result was found for the Water scale, where the average value was significantly lower in the GP sample compared to the $\mathrm{CZ}$ population, $t(13789)=9.50, p<.0001, d=0.44$. Nevertheless, the observed difference did not even reach the medium effect size value $(0.5)$.

Table 3. Descriptive characteristics of the raw scores of the four main 4EI scales for both samples

\begin{tabular}{lccccccccc}
\hline & \multicolumn{3}{c}{ Sample GP $(\mathrm{N}=13298)$} & & & \multicolumn{3}{c}{ Sample CZ (N=493) } \\
& Air & Earth & Fire & Water & & Air & Earth & Fire & Water \\
\hline Mean & 14.42 & 17.51 & 13.06 & 12.24 & & 14.52 & 16.89 & 12.19 & 14.35 \\
Median & 14.5 & 18 & 13 & 12 & & 15 & 17.5 & 12 & 14.5 \\
Mode & 14 & 21 & 15 & 11 & & 13 & 20 & 10 & 16 \\
Std. Dev. & 4.31 & 4.44 & 5.79 & 4.85 & & 4.52 & 4.82 & 5.83 & 4.70 \\
Variance & 18.61 & 19.71 & 33.53 & 23.57 & & 20.46 & 23.19 & 33.94 & 22.10 \\
Skewness & -.18 & -.77 & -.10 & .12 & & -.21 & -.57 & .11 & -.12 \\
Kurtosis & -.27 & .20 & -.79 & -.53 & & -.35 & -.32 & -.88 & -.50 \\
\hline
\end{tabular}

\section{Item analysis}

All items were validated for their difficulty and correlation with the RS; for both samples (GP and CZ), no item had a lower difficulty than .1 or higher difficulty than .9 , and all items correlate with the corresponding HS element on a .2 level or higher, where the average correlation of the items with the RS they form was in the range of .39 (Air), through .42 (Earth), .43 (Water), to .51 (Fire). 


\section{Correlation between the RSs of individual elements}

Both correlational studies for the GP sample (Table 4) and CZ sample (Table 5) suggest negative correlations between the Fire and Water elements, as well as between the Air and Earth elements. These correlations do not exceed .45; due to the low resulting coefficient of determination (approx. 20\% mutual variance), we consider these pairs to be individual dimensions, rather than two poles of a single dimension. Aside from the aforementioned pairs, we repeatedly found an even stronger positive correlation between the Fire and Air element pairs, which is probably related to extroversion and orientation towards contact with other people, which is very typical for both of these elements.

Table 4. Correlation between the RS of individual elements in the GP sample $(N=13298)$

\begin{tabular}{lccc}
\hline & Air & Earth & Fire \\
\hline Air & - & - & - \\
Earth & -.36 & - & - \\
Fire & .49 & -.07 & - \\
Water & -.07 & -.03 & -.41 \\
\hline
\end{tabular}

Table 5. Correlation between the RS of individual elements in the CZ sample $(N=493)$

\begin{tabular}{lccc}
\hline & Air & Earth & Fire \\
\hline Air & - & - & - \\
Earth & -.45 & - & - \\
Fire & .47 & -.18 & - \\
Water & -.08 & .06 & -.44 \\
\hline
\end{tabular}

\section{Reliability}

For both samples, a high reliability level was found, as measured both by the Guttman coefficient, as well as by Cronbach's $\alpha$ (see Table 6), for all element scales, where the Fire element scored the highest for both samples, followed by Earth and Water with comparable values, and the lowest values was found for the Air element in both standardization samples. Nonetheless, the reliability values still correspond to an expected level for personality test scales (above .7).

\section{Factor structure}

For the exploration of the factor structure of the 4EI questionnaire, we used EFA with the principal axis factoring method of extraction (Varimax rotation), where we chose the apriori number of 4 factors. The model found explains $20.9 \%$ of the overall variance of the 100 -item questionnaire, factor 1 (Fire) $6.9 \%$, factor 2 (Earth) $5.4 \%$, factor 3 (Water) $5.0 \%$, factor 4 (Air) 3.7\%. Table 7 shows the correlations between individual element scores 
and factor scores derived from the aforementioned exploratory factor analysis. In table 8, as a comparison, we indicate the results of the correlations between the raw 4EI scores and factor scores from the $\mathrm{CZ}$ study conducted during the standardization in 2008 and GP study from 2018.

Table 6. Reliability of the 4EI questionnaire for both standardization samples

\begin{tabular}{llllll}
\hline & \multicolumn{2}{l}{ Cronbach's $\alpha$} & & Split-half \\
\cline { 2 - 3 } \cline { 5 - 6 } & GP & CZ & & GP & \\
& $(2018 ; \mathrm{N}=13298)$ & $(2008 ; \mathrm{N}=493)$ & & $(2018 ; \mathrm{N}=13298)$ & $(2008 ; \mathrm{N}=493)$ \\
\hline Air & .77 & .79 & .77 & .81 & .77 \\
Earth & .81 & .84 & .89 & .88 & .91 \\
Fire & .88 & .81 & .81 & .83 \\
Water & .82 & & &
\end{tabular}

Table 7. Correlation between the elements' RSs and factor scores for the GP sample $(N=13292)$

\begin{tabular}{lcccc}
\hline & Factor score 1 & Factor score 2 & Factor score 3 & Factor score 4 \\
\hline RS Fire & $\mathbf{. 9 5}$ & - & - & - \\
RS Earth & -.03 & $\mathbf{. 9 6}$ & - & - \\
RS Water & -.33 & -.01 & $\mathbf{. 9 0}$ & - \\
RS Air & .43 & -.41 & .22 & $\mathbf{. 7 1}$
\end{tabular}

Table 8. Correlation between the elements' $R S$ s and factor scores for the CZ sample (N=493)

\begin{tabular}{lcccc}
\hline & Factor score 1 & Factor score 2 & Factor score 3 & Factor score 4 \\
\hline RS Fire & $\mathbf{. 9 1}$ & - & - & - \\
RS Earth & -.05 & .95 & - & - \\
RS Water & -.28 & -.02 & $\mathbf{. 8 2}$ & - \\
RS Air & .36 & -.39 & .30 & $\mathbf{. 7 1}$ \\
\hline
\end{tabular}

Again, the results from the new sample (GP) replicate the results obtained earlier from the representational population sample $(\mathrm{CZ})$. The strongest relationship exists between the factor score of the second factor and RS Earth, followed by a very strong relationship between the first factor and Fire RS. The correlations are strong enough to consider them virtually identical. The third factor also correlates strongly with the RS of the Water element; in the GP sample, the correlation is close to .9, and in the CZ sample it was closer to .8. The fourth factor score is most closely related to RS of the Air element, where it exceeded .7 correlation coefficient for both samples. 


\section{Discussion}

This replication study aimed to compare the results of the psychometric analysis of 4EI on the two different samples: the general population (GP) and the Czech standardization sample (CZ).

Firstly, the paper introduced the basic descriptive characteristics of the 4EI scales for the general population (GP) and compared them to the results obtained from the standardization sample of the Czech population from 2008 (CZ). The differences between the raw scores for both samples were observed; the Air scale did not show a statistically significant difference, for the Earth and Fire scales, the difference was significant, albeit with a low effect size not exceeding the .2 value. In the Water scale, a statistically significant difference was also found, but again with a low/middle effect size not exceeding the value of .5. Therefore, the distribution of RS in the Czech population can be considered stable and the GP sample could be potentially used as a standardization sample for the working population.

The item analysis pointed to stable characteristics of the items fulfilling the quality criteria both from a difficulty point of view, as well as from the perspective of expected correlations with individual RSs. The reliability measured by the internal consistency and split-half proved to be high for all scales (from .77 to .91); for both samples, the highest reliability was found for the Fire scale and the lowest for the Air scale. Currently, we are working on IRT analysis including the DIFs for all items, so we would be able to provide even more detailed descriptions of item functioning.

Using the EFA, we decided to study the latent structure of the data on both samples (GP and $\mathrm{CZ}$ ) separately and compare the correlations of RSs of elements with the derived factor scores. We consider the fact that EFA shows the appropriate categorization of items without our intervention or help as a non-trivial finding that can enrich item analysis in an interesting way (especially for small samples). In both samples, we found very strong correlations between factor scores and raw scores (RSs) of individual scales (in the range of .96 to .77), which shows the strong relation of RSs with factors in the background of the latent structure of the questionnaire. For both $\mathrm{CZ}$ and GP sample, the two elements with the strongest relation to the factor scores (Fire and Earth) were also the elements for which people exhibited the highest degree of agreement in terms of the attributed characteristics as part of the study examining the usage of the element metaphors to describe personality traits (Abramčuk, 2009).

We are currently preparing an article on the construct validity of 4EI. We focus on convergent and discriminatory validity in the form of correlations with other personality and temperament questionnaires, and also on confirming the latent structure of 4EI. A large sample (GP) allowed us to process data using CFA. We compare its results not only with the CFA results of other personality and temperament questionnaires, but also with the results of ESEM - exploratory structural modeling (Asparouhov \& Muthén, 2009). This approach has recently proved to be useful in investigating the latent structure of the complex personality questionnaires for which the restrictive CFA does not appear to be the most appropriate statistical tool (Hopwood \& Donnelland, 2010; Marsh et al., 2010; Toth-Király, Bõthe, Rigó, \& Orosz, 2017). 
Regarding other language versions, we are collecting a new large quota representative sample from the USA, so that we could perform CFA and ESEM for the English version as well and compare its latent structure with the Czech version of 4EI.

\section{Literature}

Testcentrum (2001). Standards for Educational and Psychological Testing of American Psychological Association. Prague, Czech Republic: Author.

Abramčuk, F. (2009). Elements as a metaphor of personality. Doctoral thesis, Charles University, Prague, Czech Republic. Retrieved from: https://is.cuni.cz/webapps/zzp/detail/80105

Abramčuk, F. (2011). Test Four Elements and its relation to some other tests of personality. E-psychologie 5(4), 1-10. Retreived from: https://e-psycholog.eu/pdf/abramcuk.pdf

Asparouhov, T., \& Muthén, B. (2009). Exploratory structural equation modeling. Structural Equation Modeling, 16(3), 397-438. http://doi.org/10.1080/10705510903008204

Bahbouh, R., Fajmonová, D., Lukavský, J., Barešová, A., Abramčuk, F., Rozehnalová E., et al. (2006). Jak živly psychometricky ožívají. Psychologie dnes, 12(5), 34-37.

Bahbouh, R., Rozehnalová, E., Fajmonová, D., \& Sněhotová, J. (2012). 4Elements Inventory ${ }^{\circledR}$ : Elements as an approach to understanding the personality. In R. Bahbouh, E. Rozehnalová, \& V. Sailerová (Eds.), New perspectives of psychodiagnostics (pp.17-32). Prague, Czech Republic: QED GROUP.

Bahbouh, R., Höschlová, E., \& Tefelnerová, P. (in press). 4Elements Inventory ( $5^{\text {th }}$ version): Manual. Prague, Czech Republic: QED GROUP.

Ball, P. (2004). The elements: a very short introduction. Oxford: Oxford University Press.

Břeň, D., \& Heřman, O. (2019). Temperament and achievement motivation of professional soldiers. In P. Kačmár, J. Bavol'ár, L. Lovaš (Eds.), Psychology of work and organization 2018 - Past, present, and challenges to the future: International Conference - Proceedings (pp. 79-91). Univerzita Pavla Jozefa Šafárika v Košiciach.

Chamoro-Premuzic, T. (2014). Personality and individual differences. London, UK: John Wiley and sons (3rd edition).

Cloninger, C. R. (1999). The Temperament and Character Inventory-Revised. St. Louis, MO: Center for Psychobiology of Personality, Washington University.

De Raad, B. (2009). Structural models of personality. In P. J. Corr, \& G. Matthews (Eds.), The Cambridge handbook of personality psychology (pp. 127-147). New York, NY: Cambridge University Press. http://doi.org/10.1017/CBO9780511596544.011

Hippokrates (1881). On airs, waters, and places. London: Messrs. Wyman and sons. Retrieved from https://archive.org/details/b23983139/page/n3 
Hochel, M., Fajmonova, D., Rozehnalova, E., \& Bahbouh, R. (2011). 4Elements Personality Inventory: a new approach to personality assessment in organization. Paper presented at the 5th International Conference on Psychology, Athens, Greece.

Hopwood, C., \& Donnellan, M. (2010). How should the internal structure of personality inventories be evaluated? Personality and Social Psychology Review: An Official Journal of the Society for Personality and Social Psychology, 14, 332-46.

http://doi.org/10.1177/1088868310361240

Fajmonova, D., \& Bahbouh, R. (2008). The four-factor personality test based on 4 elements [Abstract]. International Journal of Psychology (Special Issue: Abstracts of the XXIX International Congress of Psychology), 3-4, 137.

Fajmonová, D., Bahbouh, R., Rozehnalová, E., \& Hochel, M. (2011). 4Elements Personality Inventory: Relationship between dominant element and professional occupation. Paper presented at the 12th European Congress of Psychology, Istanbul, Turkey.

Farmer, R. F., \& Goldberg, L. R. (2008). A psychometric evaluation of the revised Temperament and Character Inventory (TCI-R) and the TCI-140. Psychological Assessment, 20(3), 281-291. http://doi.org/10.1037/a0012934

Frainšicová, K. (2013). Coherence between personal characteristics and practicing sports activities [Master's thesis]. Charles University, Prague, Czech Republic.

John, O. P., Naumann, L. P., \& Soto, C. J. (2008). Paradigm shift to the integrative Big-five trait taxonomy: History, measurement, and conceptual issues. In O. P. John, R. W. Robins, \& L. A. Pervin (Eds.), Handbook of personality: Theory and research (pp. 114-158). New York, NY: Guilford Press.

Koldová, B. (2014). Manager personality typology according to the 4Elements Inventory test. Master's thesis, Prague College of Psychosocial Studies, Prague, Czech Republic. Retrieved from http://www.pvsps.cz/data/2017/04/10/15/koldova_barbora.pdf

Marsh, H. W., Lüdtke, O., Muthén, B., Asparouhov, T., Morin, A. J. S., Trautwein, U., \& Nagengast, B. (2010). A new look at the big five factor structure through exploratory structural equation modeling. Psychological Assessment, 22, 471-491. http://doi.org/10.1037/a0019227

Matthews, G., Deary, I. J., \& Whiteman, M. C. (2003). Personality traits. Cambridge: Cambridge university Press (2nd edition). http://doi.org/10.1017/CBO9780511812736

Rozehnalova, E., \& Bahbouh, R. (2010). Development and psychometric properties of the 4Elements personality test (5th version). Poster session presented at the 15 th European Conference on Personality, Brno, Czech Republic.

Řežábková, M. (2018). Biological theories of temperament [Master's thesis]. Charles University, Prague, Czech Republic.

Rupp, R. (2005). Four Elements. London, UK: Profile books. 
Tóth-Király, I., Bõthe, B., Rigó, A., \& Orosz, G. (2017). An illustration of the Exploratory Structural Equation Modeling (ESEM) framework on the Passion Scale. Frontiers in Psychology, 8, 19-68, http://doi.org/10.3389/fpsyg.2017.01968

\section{Corresponding author}

PhDr. Eva Höschlová, Ph.D.

Charles University, Faculty of Arts, Department of Psychology

Celetná 20, 11000 Prague, Czech Republic

eva.hoschlova@ff.cuni.cz 


\title{
Validation of the Emotion Recognition Test
}

\author{
Radvan Bahbouh ${ }^{1}$, Ivana Fabianová ${ }^{1}$, Alžběta Knorková ${ }^{1}$, Eva Chroustovál \\ ${ }^{1}$ Charles University, Czech Republic
}

\begin{abstract}
Objectives. The Emotion Recognition Test (ERT) was introduced last year as a new tool to measure the ability to recognize emotions (Bahbouh \& Fabianová, 2019). This paper adds the support for convergent validity as well as a support for validity based on the way in which the test items were answered.
\end{abstract}

Method. The ERT consists of recognizing the seven emotions (anger, contempt, surprise, happiness, sadness, fear and disgust) presented on 44 photographs that appear in a random order for a period of three seconds at a time. The test is standardized based on a Czech sample of 334 respondents $(C r o n b a c h$ 's alpha $=0.77$ ). For the purposes of construct validation, the MSCEIT test was used based on a sample of 65 quota-selected volunteers, and for the overall score as well as for the partial dimensions of the MSCEIT, the correlation significances were tested as part of the convergence validity. For the support of validity based on the way in which the items were answered, two workshops focused on recognizing emotions for students were used, wherein one group $(N=19)$ was tested at the beginning of the workshop and the second $(N=18)$ was tested at the end.

Results. The Pearson correlation of the ERT and the overall score of emotional intelligence measured by the MSCEIT was significant $(r=0.294, p=0.009)$. In terms of the individual dimensions of emotional intelligence, the correlations with Using emotion $(r=0.383, p=$ $0.001)$ and Understanding emotion $(r=0.232, p=0.032)$ were significant. In the study focused on the validity given by the way in which test items were answered, the students in both groups used their understanding of the manifestation of emotions when responding to the questions. The previously instructed group achieved statistically significantly better results in the ERT ( $t$ $=3.396, d=1.117)$.

Conclusions. Results of both studies support the validity of the ERT, whose main advantage is a low time intensity. Additionally, the utilization of the test as part of training in the given competence was investigated.

Limitations. A limitation of both studies is the relatively small sample in the Czech Republic.

Keywords. Emotional recognition; emotional intelligence; basic emotions; ERT; MSCEIT

https://doi.org/10.5817/CZ.MUNI.P210-9488-2019-6 


\section{Introduction}

The Emotion Recognition Test (ERT) (Bahbouh \& Fabianová, 2019) is a performance diagnostic method focusing on one of the elements of emotional intelligence - recognizing emotions of other people (Mayer, Salovey, \& Caruso, 2000). The test consists in estimating the seven basic emotions (anger, contempt, surprise, happiness, sadness, fear and disgust) according to the concept of Ekman (1999), presented on 44 photographs appearing in a random order for periods of 3 seconds at a time. The test is standardized based on a Czech sample of 334 respondents. Its main advantage (Bahbouh \& Fabianová, 2019) is its simplicity and speed (the average completion takes 6 minutes on average), as well as a high reliability (Cronbach's alpha and the split half reliability estimation both resulted equally in 0.77 for the given sample).

Up to now, the support of validity based on the test's content were maintained by a comparison of the vocational subgroup "Psychology and Sociology" $(n=95)$ with the rest of the population $(p<0.001, d=0.67)$ (Bahbouh \& Fabianová, 2019), in accordance with the APA Standards of Educational Psychological Testing (American Educational Research Association, American Psychological Association, \& National Council on Measurement in Education, 2001). The objective of this article is to introduce two further studies supporting the validity of the test according to the APA Standards of Educational Psychological Testing (American Educational Research Association, American Psychological Association, \& National Council on Measurement in Education, 2001). The first of these supports the convergent validity by the correlation of the ERT results with the overall score of emotional intelligence as well as with the individual MSCEIT dimensions (Mayer, Salovey, \& Caruso, 2012), which are perceiving, understanding, using and managing emotions.

The second supports validity by examining the way in which the ERT items are answered. In prior analyses, it had been shown that the higher the presented item was in the order of the items' succession, the higher the likelihood of answering correctly $(r=0.66, p<$ 0.001). Given the random order of the individual photographs, we considered this a manifestation of the learning that occurred throughout the completion of the test, even without feedback. The goal of a validation by the way in which items were answered is to confirm whether the ERT is able to capture a shift in one's ability to recognize emotion following the program that introduces the students to the principles of recognizing emotion.

\section{Methods}

\section{Reaserch sample}

The data collection for the convergent validation was performed between May-June of 2017 in cooperation with Psychology students of the Charles University Faculty of Arts as part of Alžběta Knorková's diploma thesis (2018). Each student selected 6 people using a quota strategy - a man and a woman in three age categories $(20-35,36-50,51+)$. Education and profession were also being observed. The research sample for the validation by the way items were being answered was obtained as part of high school coursework, where students were divided via self-selection into two instances of workshops dedicated to recognizing emotions, each limited to a capacity of 20 people. 


\section{Research process}

The respondents confirmed their interest in participating in the correlation validation study by filling out a form, where they agreed with the processing of their anonymized data and shared their e-mail to which their access to the ERT and MSCEIT was sent. They were also informed of the ethical principles and the possibility to quit the experiment at any time without finishing the testing. Upon a completion of the test, they received an interpretation of their results, as well as the contact information of a psychologist whom they could turn to for further consultation if interested. The students' agreement with their participation in the workshop aimed at recognizing emotions was given using an informed choice of this voluntary workshop lead by the school psychologist.

To compare the effect of the provided information on the test's performance, an inbetween design comparison of the two groups was used. While one group first completed the test and only then were they instructed on how emotions are manifested in one's face (the workshop's content was the theory of recognizing the basic emotions according to Ekman's concept), the second group was first introduced to the manifestation of emotions in one's face (the same presentation) and subsequently took the test. The test was completed during the workshop using an online platform, where the test is available and accessible through a uniquely generated login, specific to each individual student. The test was also evaluated automatically, the instructor did not have access to the data, and the students were informed of the results attributed to their proprietary login credentials. The testing instructions were also presented on the first page before the actual testing commenced.

A part of the validation by the way items were answered was a discussion on the recognition of emotions, the difficulty of the test's items, and on whether the students felt that they utilized their knowledge and experience concerning emotions. One of the objectives of this qualitative part was to capture any potential misunderstanding regarding the test, as well as various strategies of answering the items that do not correspond to the authors' original intentions.

\section{Tools used}

Besides the aforementioned ERT test, the MSCEIT test was also used for the construct validation; this test is designed to measure emotional intelligence (seeing as it does not have norms for the Czech population, the German-Austrian comparison sample of 3653 probands is used). The test's internal consistency is 0.91 and the test-retest reliability estimate of the overall score is 0.86 . The individual subtests have a lower reliability, which is why it is recommended to use aggregate scores for the interpretation rather than those of the subtests (Mayer, Salovey, $\&$ Caruso, 2012). Moreover, the test also indicates the global scores of strategic emotional intelligence and emotional intelligence given by experience (Mayer, Salovey, \& Caruso, 2004). The test administration normally takes 30-45 minutes. 


\section{Results}

In the study of convergent validity, 72 subjects were asked to participate. After removing those that did not finish one or both questionnaires, the resulting sample size was 65 (33 males, 32 females) with an average age of 40 years $(M=40.15, S D=13.23)$. The sample included 33 people $(51 \%)$ with a highest achieved education of secondary school or vocational college, 11 people (17\%) with a Bachelor education and 21 people (32\%) with a Master's education. The research sample also included various professions. The most frequent one was formed by people from the construction and manufacturing industry $(N=7)$, followed by people from IT fields. In the second research, the final group sizes were 19 and 18, comprised of students of comparable ages.

The main research hypothesis for the convergent validation was a positive correlation of individual subtests with the overall MSCEIT and ERT score. Given this assumption, the significance was calculated using one-tailed testing.

Table 1. Pearson Correlation of MSCEIT a ERT results (N=65) (adopted from Knorková, 2018)

\begin{tabular}{|c|c|c|c|c|c|c|c|c|}
\hline & & $\begin{array}{l}\text { Perceiving } \\
\text { emotion }\end{array}$ & $\begin{array}{l}\text { Using } \\
\text { emotion }\end{array}$ & $\begin{array}{l}\text { Understanding } \\
\text { emotion }\end{array}$ & $\begin{array}{l}\text { Managing } \\
\text { emotion }\end{array}$ & $\begin{array}{l}\text { EI based on } \\
\text { experience }\end{array}$ & $\begin{array}{l}\text { Strategic } \\
\text { EI }\end{array}$ & $\begin{array}{l}\text { Overall } \\
\text { EI }\end{array}$ \\
\hline $\begin{array}{l}\text { ERT } \\
\text { result }\end{array}$ & $\begin{array}{l}\text { Pearson's } \\
\mathrm{r}\end{array}$ & .098 & $.383^{*}$ & $.232 *$ & .107 & $.265^{*}$ & $.250 *$ & $.294 * *$ \\
\hline
\end{tabular}

* Correlation is significant on a 0.05 significance level (one-tailed testing)

** Correlation is significant on a 0.01 significance level (one-tailed testing)

The correlation between the test of recognizing emotion and the overall score of emotional intelligence measured by the MSCEIT is statistically significant $(r=0.294, p=$ 0.009). Both global scores of emotional intelligence yielded a significant level - emotional intelligence based on experience $(\mathrm{r}=0.265, \mathrm{p}=0.016)$, as well as strategic emotional intelligence $(r=0.250, p=0.022)$. From the individual parts of the MSCEIT dimensions, the correlation between the ERT and Using emotions was significant $(r=0.383, p=0.001)$, as well as the correlation with Understanding emotion $(r=0.232, p=0.032)$. On the other hand, the correlations of the ERT and Managing emotion $(r=0.107, p=0.198)$, as well as Perceiving emotion ( $r=0.098, p=0.219)$ were not significant.

In the validation by the way items were answered, it was also researched whether people who were familiar with the theory of recognizing emotions were more capable of correctly categorizing emotions found on previously unseen photographs. The first group $(\mathrm{N}=19)$, which took the ERT prior to the presentation (interpretation), should have a disadvantage compared to the second group $(\mathrm{N}=18)$, which listened to the interpretation before the testing; this should be reflected in a lower success rate of the former group in the test. Seeing as the Shapiro-Wilk test indicated a normal distribution of the collected data $(\mathrm{W}(37)=0.962, \mathrm{p}=0.235)$, a twotailed t-test was used, based on which it was confirmed that the first $(\mathrm{M}=51.79, \mathrm{SD}=13.164)$ and second $(\mathrm{M}=66.83, \mathrm{SD}=13.785)$ groups significantly differed in their ERT results $(\mathrm{t}(35)$ 
$=-3.396, p=0.002 ; \mathrm{d}=1.117)$. There was only one major outlier in the first group with a score of 11 (however, even after its removal the resulting differences between the groups remain significant).

Figure 1. Distribution of ERT results in both groups

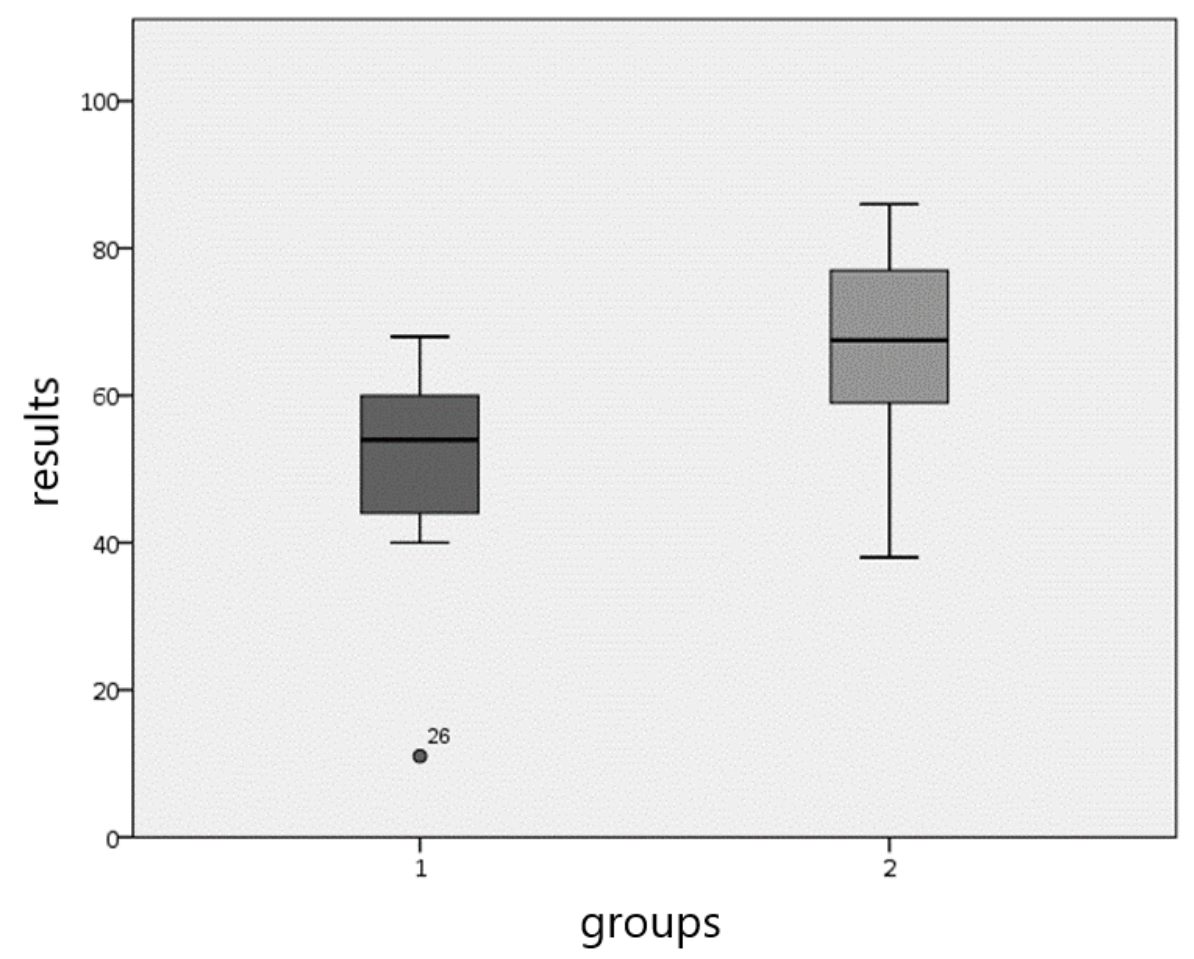

Discussion

The significant correlation between the result of the ERT and the overall score of the MSCEIT $(r=0.294)$ was an expected finding, given that the ERT was constructed such that it measures one of the dimensions of emotional intelligence - recognizing the emotions of other people. The MSCEIT can be considered the golden standard of emotional intelligence performance testing (Wilhelm, 2007), certainly also because those that originally came up with this concept participated in its construction (Salovey \& Mayer, 1990; Mayer, Salovey, Caruso, $\&$ Sitarenios, 2001; Mayer, Salovey \& Caruso, 2006, 2012). In terms of the ERT's construction, the most similar subtest of the MSCEIT is a test of the recognition of emotions from the photographs of four (subsequent) faces. Unlike Ekman's list of emotions used in his METT and SETT tests (Ekman, 2003), there is a slightly different use of basic emotions. ERT is using contempt and disgust and MSCEIT is using preoccupation and revulsion.

The probands are further instructed to rate the emotion's intensity. This subtest is a part of the Perceiving emotion dimension, for which, however, a significant correlation was not found $(r=0.098, p=0.219)$. This result could also be given by the fact that Perceiving emotion is also observed by another subtest. The items of this subtest consist of six photographs of nature and pictures of abstract patterns, to which the aforementioned emotions are assigned. This subtest strays further from the diagnostic objective, and consequently also from the construction 
of the ERT, which is also apparent from the actual definition of Perceiving emotion, which the authors (Mayer, Salovey, 2012) believe to be "the ability to perceive emotion in yourself and others, but also in objects, art, stories, music and other stimuli". The result could be also given by the difference between ERT and MSCEIT Perceiving emotion as each method measures emotional intelligence in a different way. For example, in MSCEIT there is unlimited time to view the photos and evaluate the emotion. In ERT there is limited time to view the picture and base on that short time period the proband is supposed to choose one of the emotions. So in MSCEIT, the pictures could express a mix of emotions but in ERT the photos expresses only one emotion. The reason of this result could be also because each method uses different emotions. The correlation between the ERT and Managing emotion also turned out not to be significant ( $r=0.107,0.198$ ), defined by the authors as "the ability to be open to feelings and to modulate them in oneself and others so as to promote personal understanding and growth". This dimension, too, is further removed from the original construction of the ERT. The highest correlation was found between the ERT and Using emotion $(r=0.383)$, i.e. the part of emotional intelligence based on experience, which is defined as "the ability to generate, use, and to feel emotion as necessary to communicate feelings, or employ them in other cognitive processes." The authors suppose this result is caused by the similarity of those two concepts. They both based on the practical experience. The next highest significance was found in the dimension of emotional intelligence falling under the category of strategic emotional intelligence, called Understanding emotion (0.232), defined as "the ability to understand emotional information, how emotions combine and progress through relationship transitions, and to appreciate such emotional meanings." It thus seems that the ERT better estimates the cognitive components of emotional intelligence. We would like to explore this area further in the future through factor analysis on a level of individual subtests of the MSCEIT. In addition, we would like to extend our investigation to a larger sample of not only Czech probands, which we consider one of the limitations of our study.

In terms of the second study, we wanted to use the workshop on recognizing emotions as a venue to discuss with those that were taking the test how well they understood the test instructions and how they approached its completion. The discussion suggested that the test can also be utilized for a group of high school students. Even though the students were taking the test in the classroom, there should not have been any mutual influencing, as they were filling out the answers on a computer and the test items had been randomly generated and only exposed for three seconds. The presentation on recognizing emotions did not include any items in the test, in order to prevent their memorization.

A certain limitation of our experiment is the in-between design combined with the fact that the students were not assigned into their groups at random, but rather registered for a time slot that suited them. These circumstances could have theoretically led to a different principle of randomization, as well as a potential influence of the time of the day. Better results for the intervention group could also have been achieved by an increased effort while taking the test, based on the belief that the workshop could have helped them (see Foroughi, Monfort, Paczynski, McKnight, \& Greenwood, 2016). Since this was a performance test, in which (according to the school psychologist's assumption) the students wanted to do well in both groups (they were not informed of the different assignment times of both groups), we assume 
this effect did not play any significant role in our research.

The fact that it is possible to develop one's ability to recognize emotions through more detailed information about emotions and their manifestations in people's face, as well as through a subsequent training of this capability, is not only a further support of validity based on the approach taken when answering the items, but also an interesting contribution to the discussion about the possibilities of emotional intelligence and how to develop its dimensions. The study dealing with the development of emotional intelligence is divided, according to the research of Dulewicz and Higgs (2004), into two larger parts. Those that view emotional intelligence as a trait or competence agree that it is possible to develop it (e.g. Goleman, 1996; Höpfl and Linstead, 1997). Studies that consider emotional intelligence to be a specific capability (Mayer et al., 2000) do not agree with these conclusions. The published research indicates a number of programs designed with the goal of increasing emotional intelligence (e.g. Farnham, 1996; Harrison, 1997; Cooper, 1997), whose design corresponds to a pre-test post-test model. A more detailed view on the development of emotional intelligence is provided by Dulewicz and Higgs (2004), who divided the elements of emotional intelligence into drivers, constrainers and enablers. According to their definition, they assume that enablers (exhibiting self-consciousness, sensitivity toward others and influence) are more likely to develop their emotional intelligence after participating in the course, as opposed to constrainers (high degree of conscientiousness and emotional resilience) or drivers (motivation and intuition).

A practical result of this study could be a utilization of the ERT to measure the effect of a targeted development of a given competence. For the future, we assume that the pilot sample of this study will be further enhanced by other designs, both between group and within group, allowing us to overcome the limitations given by the small sample size.

\section{Literature}

American Educational Research Association, American Psychological Association, \& National Council on Measurement in Education. (2001). Standardy pro pedagogické a psychologické testování. Praha: Testcentrum.

Bahbouh, R., \& Fabianová, I. (2019). Emotion recognition test. In A. Gregar \& M. Horák (Eds.), The International Conference of Work and Organisational Psychology 2018 (pp. 117-129). Kosice, SK: Univesity of Pavel Josef Safarik.

Cooper, R. K. (1997). Applying emotional intelligence in the workplace. Training \& development, 51(12), 31-39.

Ekman, P. (1999). Basic emotions. In V T. Dalgleish, \& M. J. Power (Eds.), Handbook of Cognition and Emotion (pp. 45-60). New York: John Wiley. http://doi.org/10.1002/0470013494.ch3

Ekman, P. (2003). Micro Expressions Training Tool and The Subtle Expressions Training Tool (METT AND SETT). MOZGO Media, Venice, CA.

Ekman, P. (2015). Odhalené emoce: naučte se rozpoznávat výrazy tváře a pocity druhých. Př́bram: Jan Melvil Publishing. 
Farnham, A. (1996). Are You Smart Enough to Keep Your Job?. Fortune, 133(1), 34.

Foroughi, C. K., Monfort, S. S., Paczynski, M., McKnight, P. E., \& Greenwood, P. M. (2016). Placebo effects in cognitive training. Proceedings of the National Academy of Sciences, 113(27), 7470-7474. http://doi.org/10.1073/pnas.1601243113

Goleman, D. (1995). Emotional intelligence: Why it can matter more than IQ. New York: Bantam Books.

Goleman, D. (1996). Emotional intelligence. Why it can matter more than IQ. Learning, 24(6), 49-50.

Harrison, R. (1997). Why your firm needs emotional intelligence. People Management, 3(1), 41.

Higgs, M., \& Dulewicz, V. (2016). Can Emotional Intelligence be Developed? In M. Higgs \& V. Dulewicz (Eds.), Leading with Emotional Intelligence (pp. 51-73). http://doi.org/10.1007/978-3-319-32637-5_5

Höpfl, H., \& Linstead, S. (1997). Introduction: Learning to Feel and Feeling to learn: Emotion and learning in organizations. Management Learning, 28(1), 5-12. http://doi.org/10.1177/1350507697281001

Knorková, A. (2018). Validizace Testu rozpoznávání emocí [Unpublished Master’s thesis]. Univerzita Karlova, Praha.

Mayer, J. D., \& Salovey, P. (1997). What is emotional intelligence. In P. Salovey, \& D. J. Sluyter (Eds.), Emotional development and emotional intelligence: Educational emplications (pp. 3-31). New York: Harper Collins.

Mayer, J. D., Salovey, P., Caruso, D. R., \& Sitarenios, G. (2001). Emotional intelligence as a standard intelligence. Emotion, 1(3), 232-242. .10.1037/1528-3542.1.3.23

Mayer, J. D., Salovey, P., \& Caruso, D. R. (2012). MSCEIT - Test emoční inteligence, Př́ručka. (P. Humpolíček, \& A. Slezáčková, Transl.) Praha: Hogrefe - Testcentrum. http://doi.org/10.1037/1528-3542.1.3.232

Salovey, P., \& Mayer, J. D. (1990). Emotional intelligence. Imagination, cognition and personality, 9(3), 185-211. http://doi.org/10.2190/dugg-p24e-52wk-6cdg

Wilhelm, O. (2007). Měření emoční inteligence: Praxe a standardy. In R. Schulze, \& R. D. Roberts (Eds.), Emoční inteligence: Přehled základních př́stupů a aplikací (pp. 151-174). Praha: Portál.

\section{Corresponding author}

Mgr. Ivana Fabianová

Charles University, Faculty of Arts, Department of Psychology

Celetná 20, 11000 Praha 1, Czech Republic

ivana.fabianova@ff.cuni.cz 


\title{
CONTRIBUTIONS IN CZECH OR SLOVAK P̌̌́SPĚVKY V ČEŠTINĚ ČI SLOVENŠTINĚ
}

\author{
Think of your financial future
}

Mysliet' na svoju finančnú budúcnost'

Viera Bačová ${ }^{1}$, Lenka Valuš²

${ }^{1,2}$ Ústav experimentálnej psychológie CSPV SAV, Slovensko

\begin{abstract}
Objective. Financial competence of an individual is not only about financial knowledge, but also about attitudes and beliefs. We regard consideration of future consequences of own financial behavior (CFC-F) as the key variable in personal finance management. That is why we focused our research on the predictors of this tendency.

Method. 50 financial professionals and 50 non-professionals with equal representation of men and women in each group, average age 37, with university (72\%) and secondary education (28\%), participated in the study. The questionnaire was administered with subscales of knowledge, attitudes, beliefs and consideration of future consequences in the personal finance domain.

Results. Linear regression analysis has shown that important positive predictors for $C F C$ - $F$ are professional experience, positive attitudes towards personal finance management, and debt rejection. Financial literacy, surprisingly, predicted CFC-F negatively.

Conclusions. Research results point to the importance of attitudes towards personal finance and suggest that financial knowledge may not contribute to considering the consequences of financial behavior. Findings can be useful in drawing up financial education programs.

Limitations. Study limits include a small sample of participants and online administration of questionnaires.
\end{abstract}

Keywords. consideration of future consequences; financial competence; financial knowledge

https://doi.org/10.5817/CZ.MUNI.P210-9488-2019-7 


\begin{abstract}
Abstrakt
Ciele. Finančná kompetencia jednotlivca zahrňuje nielen vedomosti o financiách, ale aj postoje a presvedčenia. Za klúčovú premennú považujeme tendenciu zvažovat' budúce dôsledky svojho finančného správania (ZBD-F). Preto sme sa vo výskume zamerali na prediktory tejto tendencie.

Metoda. Výskumu sa zúčastnilo 50 finančných profesionálov a 50 neprofesionálov s rovnakým zastúpením mužov a žien, priemerný vek 37 rokov, s vysokoškolským (72\%) a stredoškolským vzdelaním (28\%). Administrovaný bol dotazník s testom vedomostí a škálami postojov, presvedčení a zvažovani dôsledkov v doméne osobných financií.
\end{abstract}

Výsledky. Lineárna regresná analýza ukázala, že významnými pozitívnymi prediktormi ZBD-F sú profesionálna skúsenost', pozitívne postoje k manažovaniu osobných financií a odmietanie dlhu. Finančná gramotnost', prekvapivo, predikovala zvažovanie budúcich dôsledkov finančného správania negatívne.

Závery. Výsledky výskumu poukazujú na dôležitost' postojov k osobným financiám a naznačujú, že finančné vedomosti nemusia prispievat’ $k$ zvažovaniu dôsledkov finančného správania. Zistenia môžu byt’užitočné pri zostavovaní programov finančného vzdelávania.

Limity. K limitom štúdie patrí malá vzorka participantov a on-line administrácia dotazníkov.

Kl'účové slová. zvažovanie budúcich dôsledkov; finančná spôsobilost'; finančná gramotnost'

\title{
Úvod
}

\section{Efektívne finančné správanie a finančná pohoda}

Efektívne finančné správanie obsahuje stanovenie ciel'ov, manažovanie k splneniu ciel'ov, sporenie, investovanie (Ntalianis \& Wise, 2010), všetko činnosti, ktoré sú zamerané do budúcnosti. Správat' sa finančne efektívne znamená konat's ohl'adom na budúcnost'.

Pre efektívne finančné konanie sú nutné faktické vedomosti (Hershey, Austin, \& Gutierrez, 2015), ich nedostatok má negatívne dôsledky (Lusardi \& Mitchell, 2014; Allgood \& Walstad, 2016). Finančné správanie je však podmienené aj postojmi a presvedčeniami o finančnom svete. Skreslené presvedčenia o peniazoch môžu viest' až k patologickému správaniu (Klontz, Britt, Mentzer, \& Klontz, 2011). Finančné správanie je tiež prepojené s vlastnost’ami ako sebakontrola, tolerancia voči riziku, sebadôvera, perspektíva budúcnosti (Hershey et al., 2015). Možno ich chápat' ako antecedenty finančnej pohody. Netemeyer, Warmath, Fernandes a Lynch (2018) vymedzujú finančnú pohodu ako istotu ohl'adne svojej finančnej budúcnosti a schopnost' blokovat' neefektívne finančné správanie v prítomnosti, čo privádza ku konštruktu zvažovania prítomných verzus budúcich dôsledkov svojho správania.

\section{Zvažovanie budúcich dôsledkov (ZBD)}

Strathman, Gleicher, Boninger a Edwards (1994) uviedli Zvažovanie Budúcich Dôsledkov (d’alej ZBD) ako preferenciu časovo blízkych alebo časovo vzdialených dôsledkov 
svojho správania. Jednotlivci s nízkym ZBD sa sústred'ujú na okamžité dôsledky a budúcnost' nezvažujú vôbec alebo minimálne. Na druhej strane sú jednotlivci, ktorí zohl'adňujú budúce dôsledky a to určuje ich aktuálne rozhodnutia. Strathman et al. usilovali vysvetlit', prečo niektorí l'udia triedia odpad, dbajú o svoje zdravie, sporia na horšie časy, kým iní to nerobia. Vytvorili škálu „Zvažovanie budúcich dôsledkov“(CFC), ktorá je intenzívne využívaná.

\section{ZBD ako univerzálna vs doménovo-špecifická vlastnost'}

Strathman et al. chápali ZBD ako univerzálnu vlastnost': má ju každý jedinec na istej úrovni, ktorá je rovnaká vo všetkých oblastiach života. Paradoxne výskumy overovali škálu ZBD hladaním vzt’ahov medzi univerzálnou škálou ZBD a špecifickým správaním (napr. zdravým stravovaním; Joireman, Shaffer, Balliet, Strathman, 2012). Preto je málo známe, či a ako jednotlivec zvažuje budúce dôsledky naprieč rôznymi oblast'ami. McKay, Perry, Cole a Magee (2017) skonštruovali pre adolescentov škálu ZBD so šiestimi doménami a extrahovali štyri faktory: zdravie, globálne otepl'ovanie, vzdelanie a financie. Overili doménovú špecifickost' ZBD: adolescenti zvažovali budúce dôsledky v rôznej miere v rôznej doméne. Howlett, Kees a Kemp (2008) v skúmaní vzt'ahu medzi sporením a orientáciou na budúcnost' s použitím škály CFC potvrdili pozitívny vzt’ah medzi záujmom o sporenie na dôchodok a ZBD.

\section{Prezentovaný výskum}

Ciel'om bolo zistit' ako sa niektoré štrukturálne a osobnostné premenné podiel'ajú na ZBD svojho finančného správania (ZBD-F). Vychádzajúc z doterajších empirických zistení a z obsahu konštruktu zvažovania finančnej budúcnosti (ktoré je u zdravej populácie v nekrízovej situácii orientované pozitívne) sme predpokladali, že vyššie finančné vedomosti, pozitívny postoj $\mathrm{k}$ manažovaniu osobných financií, negatívny postoj k dlhom (ktoré znamenajú budúce náklady) a pozitívny postoj k peniazom ( $\mathrm{v}$ zmysle neodmietania peňazí ako zla) budú predikovat' vyššie skóre v ZBD-F. Zist'ovali sme aj predikčnú silu vzdelania, rodu a vykonávania finančnej profesie na ZBD-F.

\section{Metóda}

\section{Participanti}

Pre získanie finančných profesionálov s vyššou expertízou sme osobne, e-mailom a na sieti LinkedIn oslovovali možných participantov $\mathrm{s}$ informáciou o dobrovol'nej účasti a zachovaní anonymity. Po ich súhlase a vyplnení dotazníkov on-line sme podobným spôsobom vyhl'adávali finančných neprofesionálov tak, že k jednotlivým profesionálom sme párovali neprofesionálov rovnakého veku, rodu, vzdelania a vykonávania vedúcej pozície. Odlišovali sa len príjmom (priem. mesačný príjem profesionálov $1501 €$ a viac, neprofesionálov 801 až 1100 $€)$. Priemerný vek u všetkých participantov bol 37 rokov (21 až 66 rokov), $52 \%$ mužov, 72 \% VŠ a 28 \% SŠ vzdelanie. Po kontrole a splnení kritérií sme analyzovali údaje od 50 finančných profesionálov a 50 finančných neprofesionálov. 


\section{Metodiky}

Finančné vedomosti. Šest' otázok, ktoré patria k štandardnému zist'ovaniu finančnej gramotnosti v medzinárodných výskumoch (napr. Van Rooij, Lusardi, \& Alessie, 2012), obsahovali poznanie jednoduchých (inflácia, úroky, diverzifikácia rizík) a sofistikovanejších (zložený úrok, výber finančných produktov) finančných pojmov s vol’bou správnej odpovede z alternatív. Príklad otázky: Uloženie peňazi do jednej investície zvyčajne prináša bezpečnejší výnos ako uloženie peňazi do viacerých investícií. Je tento výrok, podl'a vás, nesprávny alebo správny? Za správnu odpoved' získal participant 1 bod (maximum 6 bodov).

Postoje k manažovaniu osobných financií. Podl'a dotazníka Burchela (2002) sme zostavili: 1. Škálu postojov k manažovaniu osobných financií (10 položiek; $\alpha=0,84)$, príklad položky: Aby som sa citilla bezpečne, je pre mňa dôležité venovat' dostatok času manažovaniu svojich osobných financií. 2. Škálu postojov k dlhu (10 položiek; $\alpha=0,77)$, príklad položky: Kreditná karta mi vyhovuje, pretože môžem ist' do mínusu. Participanti v týchto ako aj všetkých nasledujúcich škálach odpovedali na 4 bodovej Likertovej škále od silne súhlasím po silne nesúhlasím.

Presvedčenia o vplyve peňazí. Z dotazníka Klontza a kol. (2011; Money Script Inventory) sme použili subškály Vyhýbanie sa peniazom (Money avoidance) a Uctievanie peňazí (Money worship). Vzhl'adom na nízke hodnoty $\alpha$ sme do výpočtov zahrnuli len jednu upravenú škálu, ktorú sme nazvali „Presvedčenia o negatívnom vplyve peňazi““ (6 položiek; $\alpha$ =0,87). Príklad položky: Je t’ažké byt' bohatou a zároveñ dobrou osobou.

ZBD finančného správania. Použili sme novú, doménovo-špecifickú škálu ZBD-F (Bačová \& Kostovičová, 2018), ktorá obsahovala 6 dvojíc výrokov. Jeden pól dvojice prezentoval prítomné dôsledky, druhý budúce dôsledky finančného správania. Príklad položky: Bez ohl'adu na príjem, človek by vždy mal mat' finančnú rezervu na nepredvídané výdavky. -Netreba sa nechat' znepokojovat' finančnými problémami, ktoré možno prídu v budúcnosti. Participanti zaznamenávali svoj príklon k jednému pólu z výrokov na 7 bodovej Likertovej škále. Koeficient $\alpha$ škály ZBD-F v našej vzorke bol 0,76.

\section{Výsledky}

Aby sme overili výber participantov - finančných profesionálov a neprofesionálov a tým aj silu vplyvu vykonávania finančnej profesie na ZBD-F, porovnali sme ich výsledky v skúmaných premenných (tab. 1). Finanční profesionáli preukázali významne vyššiu úroveň finančných vedomostí, pozitívnejšie postoje k manažovaniu osobných financií a vyššie ZBD-F $\mathrm{v}$ porovnaní s finančnými neprofesionálmi. $\mathrm{V}$ negatívnom postoji $\mathrm{k}$ dlhu a presvedčeniach o peniazoch sa skupiny nelíšili. Obe skupiny mali skôr pozitívny postoj k manažovaniu, odmietali dlh a negatívne pôsobenie peňazí a prikláňali sa skôr k ZBD než k nezvažovaniu. 
Tabul'ka 1. Charakteristiky premenných u finančných profesionálov $(n=50) a$ finančných neprofesionálov $(n=50)$ a rozdiely medzi dvomi skupinami

\begin{tabular}{|c|c|c|c|c|c|}
\hline & \multicolumn{2}{|c|}{$\begin{array}{l}\text { Finanční } \\
\text { profesionáli }\end{array}$} & \multicolumn{2}{|c|}{$\begin{array}{c}\text { Finanční } \\
\text { neprofesionáli }\end{array}$} & \multirow[t]{2}{*}{ Porovnanie } \\
\hline & $M$ & $S D$ & $M$ & $S D$ & \\
\hline Finančné vedomosti & 5,88 & 1,04 & 5,26 & 1,32 & $\begin{array}{l}t(98)=2,60 ; p=0,011 \\
d=0,52\end{array}$ \\
\hline $\begin{array}{l}\text { Pozitívny postoj k } \\
\text { manažovaniu osob.financií }\end{array}$ & 3,56 & 0,38 & 3,23 & 0,48 & $\begin{array}{l}t(98)=3,75 ; p<0,001 \\
d=0,75\end{array}$ \\
\hline Negatívny postoj k dlhu & 3,22 & 0,53 & 3,31 & 0,43 & $\begin{array}{l}t(94,2)=0,89 ; \mathrm{p}=0,18 \\
d=-0,18\end{array}$ \\
\hline Negatívny vplyv peňazí & 2,31 & 0,46 & 2,37 & 0,46 & $\begin{array}{l}t(98)=0,84 ; \mathrm{p}=0,17 ; \\
d=-0,12\end{array}$ \\
\hline $\begin{array}{l}\text { Zvažovanie budúcich } \\
\text { dôsledkov finančného } \\
\text { správania }\end{array}$ & 6,27 & 0,72 & 5,86 & 0,92 & $\begin{array}{l}t(92,9)=2,47 ; p=0,015 \\
d=0,49\end{array}$ \\
\hline
\end{tabular}

\section{Prediktory ZBD-F}

Po kontrole údajov z hl'adiska korelácie prediktorov, heteroskedasticity, multikolinearity, outlierov a tzv. ,influential cases“, ako aj autokorelácie reziduálov sme pre nesplnenie kritérií vylúčili 4 participantov. Uskutočnili sme jednoduchú lineárnu regresnú analýzu so ZBD-F ako závislou premennou. Do regresnej analýzy sme zaradili údaje od všetkých participantov, aby sme zistili jednotlivé nezávislé vplyvy týchto siedmych premenných: vykonávanie finančnej profesie, finančné vedomosti, pozitívne postoje k manažovaniu osobných financií, odmietanie dlhu, presvedčenie o negatívnom vplyve peňazí na charakter človeka, rod a vzdelanie.

Ako ukázali výsledky, významnými pozitívnymi prediktormi ZBD-F sú vykonávanie finančnej profesie, pozitívne postoje k manažovaniu osobných financií a odmietanie dlhu. Významným negatívnym prediktorom ZBD-F sú finančné vedomosti. Model vysvetl'uje 32,8 $\%$ variancie premennej ZBD-F, $F(7 ; 88)=6,13 ; p<0,001$ (tab. 2 ).

Tabul'ka 2. Výsledky lineárnej regresnej analýzy

\begin{tabular}{|c|c|c|c|c|c|}
\hline \multirow[t]{2}{*}{ Model } & \multicolumn{2}{|c|}{$\begin{array}{l}\text { Neštandardizované } \\
\text { koeficienty }\end{array}$} & \multirow{2}{*}{$\begin{array}{c}\begin{array}{c}\text { Štandardizované } \\
\text { koeficienty }\end{array} \\
\beta\end{array}$} & \multirow[t]{2}{*}{$t$} & \multirow{2}{*}{$p$} \\
\hline & $B$ & $S E$ & & & \\
\hline Konštanta & 3,76 & 0,88 & & 4,27 & $<0,001$ \\
\hline Finančná profesia [nie/áno] & 0,39 & 0,15 & 0,25 & 2,65 & 0,009 \\
\hline Finančné vedomosti [0-7] & $-0,23$ & 0,07 & $-0,34$ & $-3,25$ & $\mathbf{0 , 0 0 2}$ \\
\hline $\begin{array}{l}\text { Pozitívny postoj k manažovaniu } \\
\text { osobných financií }[1-4]\end{array}$ & 0,47 & 0,19 & 0,27 & 2,52 & 0,013 \\
\hline Negatívny postoj k dlhu [1-4] & 0,60 & 0,15 & 0,36 & 3,90 & $<0,001$ \\
\hline Negatívny vplyv peňazí [1-4] & 0,22 & 0,20 & 0,11 & 1,12 & 0,268 \\
\hline Rod [muž/žena] & $-0,18$ & 0,15 & $-0,12$ & $-1,21$ & 0,230 \\
\hline Vzdelanie [S & $-0,06$ & 0,15 & $-0,03$ & $-0,38$ & 0,708 \\
\hline
\end{tabular}

\section{Diskusia}


Výsledky ukázali, že pozitívny postoj k manažovaniu osobných financií a negatívny postoj k dlhom predikuje ZBD-F. Tieto dve premenné predikujú, že participanti preferujú vo finančnom správaní budúce dôsledky pred prítomnými dôsledkami. ZBD-F pozitívne predikuje aj vykonávanie finančnej profesie. Ako prediktory ZBD-F sa nepotvrdili presvedčenie o negatívnom vplyve peňazí, rod a vzdelanie (stredoškolské vs vysokoškolské).

Prekvapivým výsledkom je, že finančné vedomosti negatívne predikujú ZBD-F: participant $\mathrm{s}$ vyššími finančnými vedomost’ami preferuje okamžité dôsledky pred budúcimi viac než participant s menšími finančnými vedomost’ami. Možným vysvetlením je vyššia sebaistota participantov s vyššími finančnými vedomost’ami a tým aj ich vyššia dôvera vo svoju schopnost' zvrátit' prípadné budúce negatívne dôsledky svojho finančného správania. Ponúka sa tiež úvaha o finančných vedomostiach, resp. finančnej gramotnosti. Nástroje na ich meranie sa často obmedzujú len na deklaratívne poznanie finančných termínov. Novší konštrukt „finančná spôsobilost"“ (financial capability) je vymedzovaný širšie, zahŕňa finančnú gramotnost', finančné správanie a vlastnú finančnú efektívnost' (Taylor, 2011; Xiao \& O'Neill, 2016). Je to schopnost' primerane aplikovat' finančné vedomosti a finančne konat' tak, aby výsledkom bola finančná pohoda (Xiao, Chen, \& Chen, 2014). V tomto zmysle finančná spôsobilost' znamená efektívne finančné správanie. Možno, ak by sme robustnejšie merali finančnú spôsobilost', preukázal by sa jej pozitívny vzt'ah so ZBD-F. On-line administrácia nášho dotazníka tiež neumožnila kontrolu, či participanti odpovedali na všetky otázky v teste finančných vedomostí samostatne.

\section{Limity výskumu}

Participantami boli zamestnaní l'udia strednej a staršej dospelosti, odlišujúci sa vykonávaním finančnej profesie. Neboli však vyberaní náhodne, čo neumožňuje širšie zovšeobecnenie výsledkov. Limitom môže byt' aj použitie neštandardizovaných metodík postojov a presvedčení o financiách. Tieto premenné zatial' neboli na Slovensku skúmané, metodiky na ich meranie v slovenskej populácii neexistujú, bolo potrebné zostavit' vlastnú metodiku ZBD-F a upravit' existujúce postojové miery.

Naše zistenia viac-menej naznačujú, že efektívne finančné správanie zohl'adňujúce finančnú budúcnost' silne súvisí s pozitívnym postojom $\mathrm{k}$ manažovaniu osobných financií a odmietavým postojom $\mathrm{k}$ dlhu, preto výsledky môžu byt' podnetné pre tvorbu vzdelávacích programov finančnej spôsobilosti.

\section{Literatúra}

Allgood, S., \& Walstad, W. B. (2016). The effects of perceived and actual financial literacy on financial behaviors. Economic Inquiry, 54(1), 675-697. https://doi.org/10.1111/ecin.12255

Bačová, V., \& Kostovičová, L. (2018). Thinking about future consequences of the present behaviour. In Č. Šašinka, A. Strnadová, Z. Šmideková, \& V. Juř́ik (Eds.), Kognice a umělý život 2018 (pp. 5-6). Brno: Flow. 
Burchel, B. (2002). Result of 300 Telephone Interviews: Attitudes, knowledge and emotions concerning personal finance. Vyhl'adané 15. 10. 2017. Dostupné na http://people.ds.cam.ac.uk/bb101/SummaryofResultsof300TelephoneInterviews.pdf

Hershey, D. A., Austin, J. T., \& Gutierrez, H. C. (2015). Financial decision making across the adult life span: Dynamic cognitive capacities and real-world competence. In T. M. Hess, J. Strough, \& C. E. Lockenhoff (Eds.), Aging and Decision Making: Empirical and Applied Perspectives (pp. 329-349). New York: Academic Press. https://doi.org/10.1016/B978-0$\underline{12-417148-0.00016-9}$

Howlett, E., Kees, J., \& Kemp, E. (2008). The role of self-regulation, future orientation, and financial knowledge in long-term financial decisions. The Journal of Consumer Affairs, 42(2), 223-242. https://doi.org/10.1111/j.1745-6606.2008.00106.x

Joireman, J., Shaffer, M. J., Balliet, D., \& Strathman, A. (2012). Promotion orientation explains why future-oriented people exercise and eat healthy: evidence from the two-factor consideration of future consequences-14 Scale. Personality and Social Psychology Bulletin, 38(10), 1272-1287. https://doi.org/10.1177/0146167212449362

Klontz, B., Britt, I. S., Mentzer, J., \& Klontz, T. (2011). Money beliefs and financial behaviors: development of the Klontz Money Script Inventory. The Journal of Financial Therapy, 2(1), http://dx.doi.org/10.4148/jft.v2i1.451

Lusardi, A., \& Mitchell, O. S. (2014). The economic importance of financial literacy: theory and evidence. Journal of Economic Literature, 52(1), 5-44. https://doi.org/10.1257/jel.52.1.5

McKay, M. T., Perry, J. L., Cole, J. C., \& Magee, J. (2017). Adolescents consider the future differently depending on the domain in question: Results of an exploratory study in the United Kingdom. Personality and Individual Differences, 104(C), 448-452. https://doi.org/10.1016/j.paid.2016.09.002

Ntalianis, M., \& Wise, V. (2010). The relevance of financial education for retirement savings behavior. International Review of Business Research, 6(1), 631-645.

Netemeyer, R. G., Warmath, D., Fernandes, D., \& Lynch, J., Jr. (2018). How am I doing? Perceived financial well-being, its potential antecedents, and its relation to overall wellbeing. Journal of Consumer Research, 45(1), 68-89. https://doi.org/10.1093/jcr/ucx109

Strathman, A., Gleicher, F., Boninger, D. S., \& Edwards, C. S. (1994). The consideration of future consequences: weighing immediate and distant outcomes of behavior. Journal of Personality and Social Psychology, 66(4), 742-752. https://doi.org/10.1037/0022$\underline{3514.66 .4 .742}$

Taylor, M. (2011). Measuring financial capability and its determinants using survey data. Social Indicators Research, 102(2), 297-314. https://doi.org/10.1007/s11205-010-9681-9 
Van Rooij, M. C., Lusardi, A., Alessie, R. J. (2012). Financial literacy, retirement planningand household wealth. The Economic Journal, 122(560), 449-478. https://doi.org/10.1111/j.1468-0297.2012.02501.x

Xiao, J. J., Chen, C., \& Chen, F. (2014). Consumer financial capability and financial satisfaction. Social Indicators Research, 118(1), 415-432. https://doi.org/10.1007/s11205013-0414-8

Xiao, J. J., \& O'Neill, B. (2016). Consumer financial education and financial capability. International Journal of Consumer Studies, 40(6), 712-721. https://doi.org/10.1111/ijcs.12285

\section{Korespondující autor}

prof. PhDr. Viera Bačová, DrSc.

Ústav experimentálnej psychológie CSPV, SAV

Dúbravská cesta 9, 84104 Bratislava, SR

viera.bacova@savba.sk

Grantová podpora: Výskum podporila VEGA MŠ SR a SAV, projekt 2/0118/17. 


\title{
New creativity and innovativeness inventory Creatixo (CIQ-CXO) - its formation and pilot verification
}

\section{Tvorba a pilotní ověření nového inventáře kreativity a inovativnosti Creatixo (DKI-CXO)}

\author{
Milan Bobek ${ }^{1}$ \\ ${ }^{1}$ Univerzita Karlova, Filozofická fakulta, Katedra psychologie, Česká republika
}

\begin{abstract}
Objectives. In this study we try to verify the reliability and validity of a new questionnaire (precisely speaking inventory) of creativity and innovativeness, based on review of existing research, tests and literature on creativity.

Method. Review identified 80 skills and personality attitudes related to a complex creativity construct according to Urban's (2002) definition. We preliminarily grouped them into 9 areas: 1. courage, 2. endurance, 3. openness, 4. imagination, 5. empathy, 6. enthusiasm, 7. assertiveness, 8. analytical and systematic thinking and 9. ability of self-development. Data collection was done on a public server with 90 respondents of a wide age, educational and professional range and further on with 35 members of company teams.

Results. 3 items were excluded by correlation analysis. The split-half method verified the reliability of the questionnaire (0.90) and its internal consistency (Cronbach's alpha of 0.91). Validisation studies have just begun, only validating the results by respondents themselves and their surroundings have been done till now and exploratory factor analysis.

Conclusions. The questionnaire proved itself to be reliable, but now it needs adjustment of some of its items according to the factor analysis, collection of new data from a representative sample, confirmatory factor analysis and a proper validation.

Limits. Testing of creativity and innovativeness just by a questionnaire. Proper validity assessment has not yet been done. We plan reduction and readjustment of items based on exploratory factor analysis that propose just 6 factors, collecting new data from a representative sample, confirmatory factor analysis and contrast validation with individuals who are known for their high creativity and innovativeness.
\end{abstract}

Keywords. creativity; innovativeness; questionnaire; test; competence development https://doi.org/10.5817/CZ.MUNI.P210-9488-2019-8 


\section{Abstrakt}

Cíle. V této studii se pokoušíme ověřit reliabilitu a validitu nového dotazníku (přesněji řečeno inventáre) kreativity a inovativnosti, který byl vytvořen na základě rešerše dosavadních výzkumů, testi̊ a odborné literatury.

Metoda. Rešerši jsme identifikovali 80 dovedností a osobnostnich rysů, které souviseji s komplexním konstruktem kreativity dle Urbanovy definice (2002). Ty jsme predběžně rozčlenili do 9 oblastí: 1. odvaha, 2. vytrvalost, 3. otevřenost, 4. predstavivost, 5. empatie, 6. nadšení, 7. asertivita, 8. analytické a systematické myšlení a 9. schopnost se rozvíjet. Sběr dat proběhl na verejném serveru s 90 respondenty v širokém věkovém, vzdělanostním i profesním rozpětí a následně na 35 členech firemních týmů.

Výsledky. Korelační analýzou byly vyloučeny tři položky. Metodou split-half byla ověřena reliabilita dotazníku (0,90) a jeho vnitřni konzistence (Cronbachovo alfa 0,91). Validizační studie byly teprve započaty. Zatím proběhlo pouze posouzení výsledkủ samotnými respondenty a jejich okolím a exploratorni faktorová analýza.

Závěry. Dotazník byl ověren jako dostatečně reliabilní, nicméně nyni bude potřeba upravit jeho položky na základě faktorové analýzy, realizovat nový sběr dat na reprezentativním vzorku a provést náležitou validizaci.

Limity. Limitem aktuálni podoby testu je zjištování kreativity a inovativnosti pouhým dotaznikem. Dosud nebylo provedeno dostatečné posouzení jeho validity. Na základě výsledkü exploratorni faktorové analýzy, která ukazuje na existenci pouze 6 faktorü, je třeba provést redukci a přeskupeni položek, posbirat nová data na reprezentativním vzorku, provést konfirmatorni faktorovou analýzu a kontrastni validizaci porovnáním výsledků jedinců známých svou vysokou kreativitou a inovativností se zbylou populací.

Klíčová slova. kreativita; inovativnost; dotazník; test; rozvoj kompetencí.

\section{Úvod}

V tomto článku seznamujeme čtenáře s postupem tvorby nového dotazníku (přesněji řečeno inventáře) kreativity a inovativnosti a s výsledky jeho ověřování na pilotní skupině 125 respondentů. Dosavadní provedené práce zahrnují rešerši odborných zdrojů, tvorbu inventáře, sběr dat na pilotním nereprezentativním vzorku, analýzu jednotlivých položek, korelační analýzu, ověřování reliability, kalkulaci prvních předběžných norem, exploratorní faktorovou analýzu a první zjišt'ování face validity. Nyní nás čeká redukce a úprava položek, nové seskupení položek do odpovídajícího počtu faktorů, sběr nových dat již na reprezentativním vzorku, konfirmatorní faktorová analýza, provedení náležitých validizačních studií a tvorba finálních norem.

Pro posouzení kreativity se u nás nejčastěji používá Torranceho figurální (případně i verbální) test tvořivého myšlení (Jurčová, 1984), dále Urbanův (2002) figurální test tvořivého myšlení, Schürerův (1977) KREATOS, což je modifikovaný Warteggův test kreativity a v poslední době i Schulerův a Hellův (2014) ASK - Test deduktivního a kreativního myšlení. 
Jejich slabinou je, že jsou až na poslední z nich jen kresebné, ale hlavně posuzují pouze část komplexního konstruktu kreativity, jak jej popisuje odborná literatura, a sice jen nápaditost, originalitu, flexibilitu a fluenci. Přitom opomíjejí ostatní složky inovativnosti nutné k dotažení nápadu až do konce a $\mathrm{k}$ jeho prosazení do praxe, jako je např. odvaha, nadšení, analytické a kritické myšlení, vytrvalost, empatie či asertivita.

Rešerší dosud provedených výzkumů, existujících testů a odborných monografií o kreativitě - z nichž za nejkomplexnější díla lze označit práce Frankové (2011), Pritzkera a Runca (2011) nebo Kaufmana se Sternbergem (2010) - jsme identifikovali 80 hlavních nejčastěji se opakujících dovedností a osobnostních a postojových rysů, které odpovídají Urbanově (2002) rozšířené definici, že u kreativity se jedná nejen o samotnou schopnost vytvářet nápady, ale také je testovat, prosazovat a finalizovat až do konkrétního produktu či služby, která bude společností přijata jako užitečná.

K tomuto seznamu kreativních rysů již od Guilforda (1950) patří především divergentní myšlení (Jurčová, 1984) měřené až podnes pomocí fluence (počtu relevantních odpovědí), flexibility (množství různých př́stupů), originality a elaborace (množství detailů).

Ale např. Kaufman se Sternbergem (2010) správně namítají, že tyto prvky vůbec nepokrývají všechny aspekty kreativity. Kromě generativní fáze tvưrčího procesu, kdy vznikají nové myšlenky (které vyžadují divergentní myšlení), rozlišují také fázi explorativní, ve které je potřeba mnoha dalších dovedností, jako je logika, analýza, syntéza nebo kritické myšlení.

Petrowski (2000) k tomu přidává intuici a vhled, schopnost udržet stabilitu a nízkou úroveň vzrušení (to znamená překonat stres a být odolní), ale zároveň jako předpoklad tvořivosti i nutnost být vystavováni určité úrovni vzrušení, novým zážitkům a podnětům.

Kaufman a Sternberg (2010) dále zdůrazňují osobnostní rysy kreativních lidí, jako je statečnost, odvaha, spontánnost a sebevědomí. MacKinnon (1975) k nim přidává sebevědomí, sebekontrolu, citlivost, emotivitu, otevřenost ke složitým podnětům a preferenci komplexnosti. Oba hovoří také o vnitřní motivaci k dosažení výsledků, překonávání překážek a dokončování věcí.

Csikszentmihalyi (1997) pak doplňuje i sociokulturní aspekty, jako je ochota vzdát se veřejného hodnocení, ale zároveň schopnost nakonec dosáhnout nezbytného souhlasu společnosti, což vyžaduje komunikační dovednosti jako je empatie, vyjednávání a asertivita.

Protože tedy na trhu aktuálně chybí nástroj, který by dokázal měřit takto komplexněji pojatou kreativitu a inovativnost, rozhodli jsme se pokusit se vytvořit vlastní dotazník a ověřit jeho reliabilitu a validitu. Samozřejmě lze může namítnout, že takto definovaný konstrukt je př́liš široký a přesahuje standardní definice kreativity.

Nelze než souhlasit, nicméně jsme přesvědčeni, že právě takovýto konstrukt je organizacemi žádán v praxi. To, že ověřování jeho validity porovnáváním s jinými nástroji měřícími jednotlivé srovnatelné složky kreativity a inovativnosti bude náročnější, je zřejmé. Nicméně není to nemožný úkol - na některé kompetence použijeme srovnání s výsledky klasických testů kreativity, na jiné s jednotlivými kategoriemi vybraných osobnostních dotazníků a u některých pak srovnání s vybranými relevantními testy sociálních dovedností. 
Pro námi vytvářený konstrukt tedy použijeme následující definici kreativity dle Urbanova (2002, s.8) vymezení, které je plně v souladu s výše uvedenými výzkumy, takže je můžeme převzít. Zní:

Tvořivost se projevuje v novém, překvapujícím produktu, je to tedy schopnost:

1. vytvořit nový, neobvyklý a překvapující produkt jako řešení citlivě vnímaného nebo zadaného problému,

2. a to na základě citlivého vnímání nejširších souvislostí předložených a dalších „vypátraných“ informací,

3. prostřednictvím analýzy a flexibilního zpracování zaměřeného na řešení, prostřednictvím neobvyklých asociací, restrukturováním nebo kombinací uvedených informací s údaji z vlastní zkušenosti a imaginace,

4. syntézou, strukturováním a skládáním těchto údajů, prvků a struktur elaborovat nová řešení (hmotná i nehmotná),

5. vyjádřená jako produkt, resp. v produktu v jakékoliv formě,

6. který je nakonec prostřednictvím komunikace s jinými chápán jako smysluplný.

Doposud bylo nutno takto šíreji chápanou inovativnost posuzovat pomocí celé baterie testů, která tím postrádala ucelenost a konzistentnost, proto jsme se rozhodli pokusit se vytvořit vlastní komplexní integrovaný nástroj.

Vzniklý inventáŕ kreativity a inovativnosti Creatixo (DKI-CXO) má sloužit k testování a rozvoji zaměstnanců firem. Jím měřený konstrukt je v souladu s Urbanovou (2002) definicí kreativity popsán tak, že díky dané kompetenci je člověk schopen vytvořit, systematicky analyzovat, kriticky a strategicky zhodnotit, prosadit a dotáhnout až do praktické realizace nový originální nápad, který se projeví v novém produktu nebo službě, bude k užitku firmě nebo společnosti a bude přijat relevantním sociálním okolím.

\section{Metoda}

Rešerší odborné literatury, existujících testů a dosavadních výzkumů jsme tedy nalezli 80 nejčastěji se vyskytujících schopností, dovedností, osobnostních rysů a postojů, které jsme podle jejich logické podobnosti rozčlenili do devíti dílčích předběžně formulovaných kategorií - základních kompetencí. Samotný dotazník DKI-CXO má po vyloučení třech dovedností na základě korelační analýzy nakonec 77 položek hodnocených 4stupňovou škálou vyjadřující míru souhlasu s uvedeným výrokem, šest demografických položek a sedm otevřených otázek.

Námi vybraných původních 80 položek, vyskytujících se v rešerších s nejvyšší frekvencí, jsme podle jejich obsahové podobnosti zatím předběžně zařadili do devíti kompetenčních oblastí. Jedná se o 1. ODVAHU A BOJOVNOST (označena kódem B), 2. VYTRVALOST (V), 3. PřEDSTAVIVOST, NÁPADITOST A UMĚLECKOST (P), 4. OTEVŘENOST (O), 5. ANALYTICKÉ A SYNTETICKÉ MYŠLENÍ, SYSTEMATIČNOST, 
KONCEPČNOST A NADHLED (S), 6. NADŠENÍ A ZVĚDAVOST (N), 7. EMPATII (E), 8. ASERTIVITU (A) a nakonec 9. SCHOPNOST SE ROZVÍJET (R).

Např́klad kompetence B ODVAHA A BOJOVNOST sestává z položek B1 - Odvaha jít do neznáma, B2 - Odvaha jít do rizika, B3 - Odvaha připustit omyly a selhání před druhými, B4 - Schopnost překonávat odmítnutí, B5 - Odvaha dělat rozhodnutí, B6 - Schopnost iniciovat změny, B7 - Bojovnost a nevzdávání se a B8 - Odvaha opouštět slepé uličky.

Každou z 80 dílčích dovedností jsme pak vyjádřili jednou sebepopisnou oznamovací větou a ty se staly jednotlivými položkami inventáře.

Např. položka B7 - Bojovnost a nevzdávání se jako součást kompetence ODVAHA, BOJOVNOST zní: „I když se někdy zdá, že je věc zcela ztracená, nikdy se nevzdávám a bojuji až do úplného konce.“ Nebo položka P2 - Plynulý tok nápadů, která je součástí kompetence PŘEDSTAVIVOST, NÁPADITOST A UMĚLECKOST zní: „Přri vymýšlení něčeho nového jsem studnicí nápadů“ či položka P3 - Originalita má podobu: „Moje nápady bývají jedinečné a originální.“

Míru souhlasu s těmito tvrzeními respondenti vyjadřují volbou ze čtyř možností (1. Rozhodně souhlasím, skoro vždy, 2. Spíše souhlasím, často, 3. Spíše nesouhlasím, zřídka a 4. Nesouhlasím, téměř nikdy.

K hodnocení dostávají instrukci, aby posuzovali své chování za dobu posledního roku, a to v pracovním, a nikoliv v osobním kontextu. A dále že u tvrzení, která mohou v jejich chápání obsahovat dvě různé části, tak aby označili volbu 1, pokud plně souhlasí s oběma částmi formulace a 2 či 3, pokud u nich přece jen převažuje př́íklon $\mathrm{k}$ jednomu $\mathrm{z}$ obou tvrzení (např́iklad ve výše uvedené položce B7 se sice obvykle nevzdávám, ale někdy věc až do úplného konce nedotáhnu). Možnost středových odpovědí je použitím nucené čtyřstupňové volby vyloučena. Pro platnost výsledků musí být zodpovězena každá ze 77 škálovaných položek inventáře. Otevřené otázky a některé demografické údaje mohou zůstat nezodpovězeny.

Výběr prvního vzorku respondentů byl příležitostný a proběhl prostřednictvím zveřejnění dotazníku na serveru www.vyplnto.cz. Pilotní testovací vzorek tak byl sestavený z osob, které si dotazník na serveru samy našly, informace o dotazníku byly dále umístěny na sociálních sítích Facebook a LinkedIn a též o něm byli informováni VŠ studenti autorů.

V pilotní ověřovací fázi položek dotazníku tak byla během čtyř týdnů shromážděna data od 90 respondentů ( $68 \%$ žen a $32 \%$ mužů ve věkovém rozpětí od studentů 2 . stupně ZŠ až po důchodce s tím, že 39 \% bylo ve věku 25-35 let a 28 \% mezi 16-24 lety, 62 \% respondentů právě studuje VŠ nebo má ukončené VŠ vzdělání. Profesní struktura byla vyvážená a pestrá od nepracujících studentů (19 \%), přes administrativní profese (13\%), manažery (12\%), pomáhající profese $(11 \%)$, podnikatele $(9 \%)$, až po důchodce $(3 \%)$ a manuální pracovníky (2 $\%$ ). Návratnost daná poměrem zobrazených a do konce vyplněných dotazníků činila $23.5 \%$ (čili dotazník si alespoň otevřelo 383 návštěvníků serveru). Mnozí se tedy nechali odradit jeho poněkud větší rozsáhlostí, než je na daném serveru běžné - vyplňování zabralo v průměru 25 minut. 
Tento vzorek samozřejmě není reprezentativní k tvorbě finálních norem, nicméně k ověření jednotlivých položek a jako základ pro další analýzy a vylepšování inventáře je podle nás dostačující, i když tento samovýběr obecnou platnost výsledků samozřejmě snižuje. To se projevilo i tím, že celkový průměrný výsledek odpovědí všech respondentů dosáhl hodnoty 59.7 \%., tedy více, než by odpovídalo ideální průměrné položce s obtížností 0.50 .

To může naznačovat, jak menší obtížnost položek, než by bylo vhodné, přeceňování se účastníků, tak i to, že zúčastnit se pilotního šetření měli větší motivaci lidé, kteří se o kreativitu zajímají více a je u nich tudíž pravděpodobný nadprůměrný výsledek.

Otevřené otázky dotazníku se ptají na aktuální a žádoucí profesi, klíčové dovednosti $\mathrm{v}$ nich potřebné, jak se v nich projevuje jejich kreativita a inovativnost a jaký zajímavý pracovní inovativní projekt by rádi realizovali. Demografické položky na úvod dotazníku jsou standardní a kromě věku, pohlaví a vzdělání umožňují i výběr z katalogu typických profesí.

V další fázi prací s daty proběhla položková a korelační analýza, ověření split-half reliability a vnitřní konzistence testu, posouzení face validity, sestavení prvních předběžných norem k porovnání ostatních respondentů s úvodním pilotním vzorkem a exploratorní faktorová analýza.

\section{Výsledky}

Po sběru výsledků od 90 prvních účastníků výzkumu jsme provedli analýzu jednotlivých položek co se týká jejich obtížnosti. Žádné prŕiliš těžké (pod 0.1) ani př́liš lehké (nad 0.9) položky nebylo nutné vyloučit. Průměrná obtížnost položek byla na úrovni 0.59 a celkově se pohybovala v rozmezí 0.37 až 0.79 .

Na základě korelační analýzy nebyly zjištěny duplicity položek, ale bylo nutné vyřadit tři položky, které měly korelaci s hrubým skórem dané oblasti pod 0.3 a tudíž se ukázalo, že s námi sledovaným konstruktem kreativity př́liš nesouvisejí. Jednalo se o pamět' (korelace s HS oblasti Analytické a systematické myšlení byla 0.28 a korelace s celkovým HS dokonce jen 0.02), umění se zklidnit (0.16 korelace s HS oblasti Představivost, nápaditost a uměleckost a 0.32 s celkovým HS) a schopnost vnímat detaily ( 0.28 korelace s HS oblasti Analytické a systematické myšlení a 0.02 s celkovým hrubým skórem).

Tabulku všech zjištěných korelačních vztahů zde neuvádíme pro její rozsáhlost. Pouze můžeme shrnout, že korelace jednotlivých položek s celkovým hrubým skórem se pohybovala v rozpětí 0.02 u již zmíněné položky Pamět' až po 0.63 a korelace jednotlivých položek $\mathrm{s}$ hrubými skóry oblastí, do kterých byly zařazeny, se pohybovala od zmíněných $0.16 \mathrm{u}$ Zklidnění až po 0.76 .

Korelace hrubých skórů jednotlivých 9 kompetenčních oblastí s celkovým hrubým skórem se pak pohybovala $\mathrm{v}$ rozmezí od 0.56 do 0.79 .

Metodou split-half byla ověřena reliabilita celého dotazníku na úrovni 0.90 a vnitřní konzistence celého testu vyjádřená Cronbachovým alfa dosáhla hodnoty 0.91 , což jsou solidní hodnoty. 
Hodnoty vnitřní konzistence u jednotlivých kompetencí nám vyšly: $\mathrm{B}-0.78 ; \mathrm{V}-0.71 ; \mathrm{P}$ - 0.77; O - 0.55; S - 0.69; N - 0.72; E - 0.79; A - 0.80 a R - 0.57. U osobnostního dotazníku považujeme hodnoty nad 0.60 za dostatečné, nad 0.70 za vysoké. $Z$ hlediska tohoto kritéria se tudíž neprokázaly jako dostatečně konzistentní soubory položek zařazených pod Otevřenost $(\mathrm{O}$ - 0.55) a Schopnost se rozvíjet $(\mathrm{R}-0.57)$. To ukazuje na potřebu ještě jisté úpravy, případně vypuštění a přeuspořádání položek minimálně v těchto dvou oblastech.

Výstupem této části prací bylo sestavení prvních předběžných norem umožňujících porovnávání dalších účastníků s pilotními respondenty. Následně jsme do této chvíle sesbírali data ještě od dalších 35 osob, povětšinou členů pracovních a manažerských týmů z některých oslovených firem.

Výsledky účastníků v samotném dotazníku jsme vyjádřili v procentech jako kreativní kvocient (označený malými písmeny - cq), a to jak celkový, tak i dílčí týkající se devíti předběžně formulovaných kompetencí. Celkový výsledek testu jsme pak u jednotlivých respondentů ještě na základě předběžných populačních norem sestavených z odpovědí prvních 90 respondenti̊ vyjádřili v podobě tzv. kreativního kvocientu (označeného velkými písmeny CQ) ve formátu IQ.

Celkový výsledný kreativní kvocient se u jednotlivých účastníků pohyboval od 29 do 87 \% (což odpovídá rozpětí 62-142 CQ) a výsledky odpovídaly normálnímu rozložení.

Nakonec jsme provedli exploratorní faktorovou analýzu v programu SPSS, která ukázala existenci jednoho, tř́, šesti nebo deseti faktorů (viz Obrázek 1).

Ze zobrazení scree plotu je vidět, že jeden faktor je zdaleka nejvýraznější, což naznačuje, že dotazník skutečně měří tvořivost jako jednu výraznější vlastnost odpovídající standardním testům kreativity (což opravňuje pokusit se jeho výsledek vyjádřit kvocientem kreativity CQ) a pak další doplňující kvality, které odpovídají Urbanově (2002) rozšířené definici aplikované kreativity a inovativnosti.

10faktorový model vysvětloval téměř $50 \%$ variability všech položek. Složení jednotlivých faktorů se mírně lišilo od námi původně navržených devíti shluků dovedností (jak naznačila analýza konzistence jednotlivých kategorií) a některé položky také sytily na podobné úrovni více faktorů.

Bylo proto nutné postupné odstraňování těchto položek a několik opakování exploratorní faktorové analýzy, dokud sycení jednotlivých faktorů položkami nebylo dostatečně jednoznačné a konzistentní. Nakonec jsme takto dospěli k modelu se 6 faktory a 47 nově př̀euspořádanými položkami.

Nově objevené faktorové kategorie jsme prozatím pracovně nazvali PROSAZENÍ SE, SAMOSTATNOST (označeno kódem A), EMPATIE, OHLED NA DRUHÉ A SOCIÁLNÍ INTERAKCE (kód E), NÁPADITOST A INOVATIVNOST (kód N), ODVAHA, ROZHODNOST, NEVZDÁVÁNÍ SE A ODOLNOST (kód O), OTEVŘENOST KRITICE A POKORA (kód P) a nakonec SYSTEMATIČNOST, DŮKLADNOST, RACIONÁLNÍ A KRITICKÉ MYŠLENÍ (kód R). Podrobnější ukázka výsledků exploratorní faktorové analýzy je již nad rámec rozsahu tohoto textu. 
Obr. 1. Faktorová analýza (šikmá rotace) naznačuje existenci jednoho, tří, šesti nebo deseti faktori

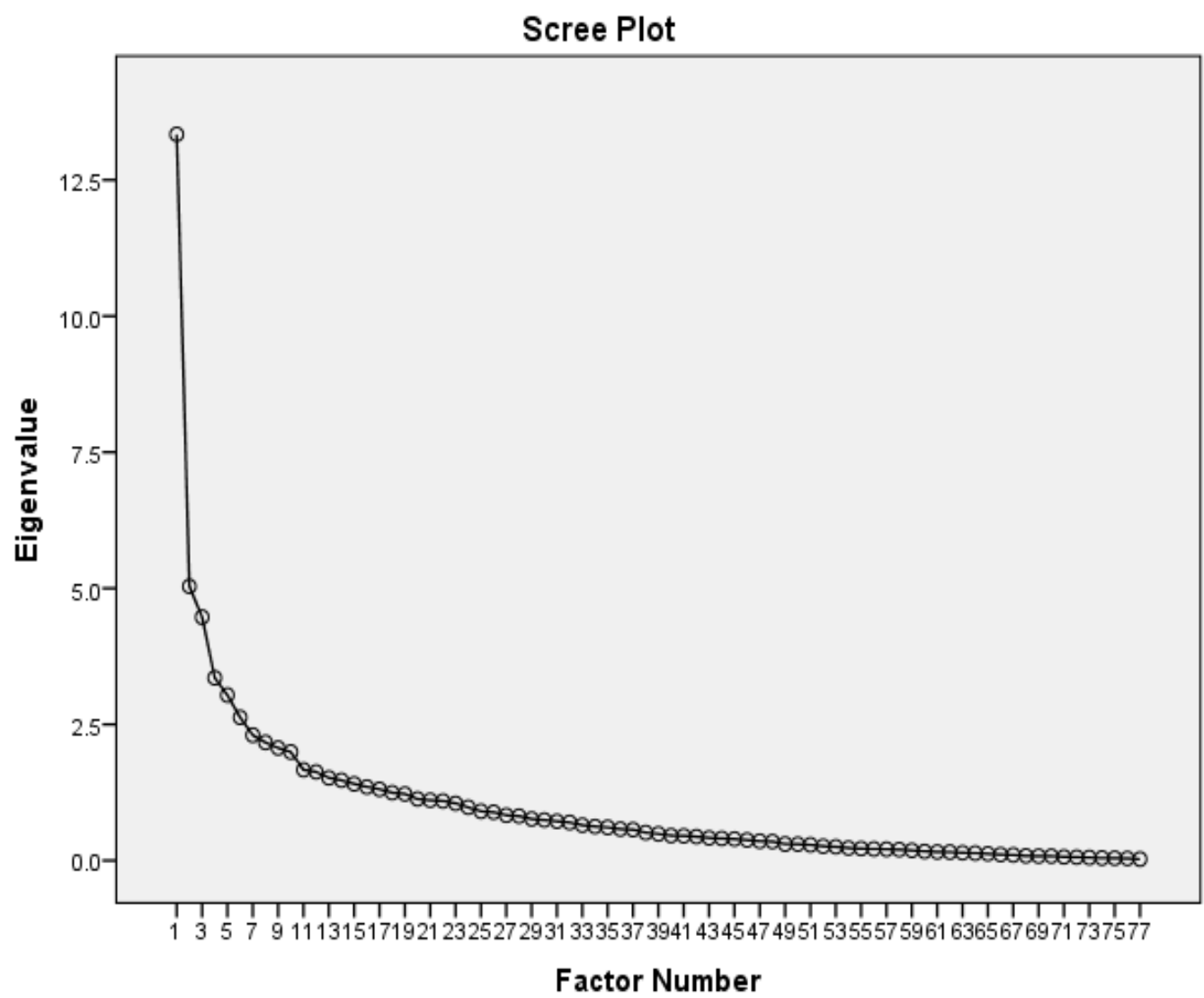

Nyní nám tedy zbývá provést nový sběr dat na reprezentativním vzorku a náš 6 faktorový model ověřit konfirmatorní faktorovou analýzou a poté provést náležitou validizaci dotazníku.

Při neexistenci vhodného uceleného ověřeného testu odpovídajícího námi definovanému konstruktu nebylo možné jej rovnou předložit respondentům spolu s naším inventářem a porovnávat jejich výsledky v našem dotazníku i s tímto standardem. $Z$ hlediska validity tedy zatím proběhlo pouze posouzení face validity samotnými respondenty, že jejich výsledky odpovídají jejich sebepoznání a sebehodnocení, dále posouzení výsledků některých respondentů lidmi, kteři je znají a též porovnání sebehodnocení vybraných respondentů s hodnocením pomocí stejného dotazníku druhým člověkem, který respondenta dobře zná.

\section{Diskuse}

\section{Závěry}

Na základě rešerší uvedené odborné literatury vznikl inventář šířeji pojaté kompetence kreativity a inovativnosti s důrazem nejenom na nápaditost, ale i na kritické zhodnocení nápadu a jeho prosazení do praxe. Jeho první představení ve firemním prostředí se setkalo s oceněním jeho komplexnosti a relevantnosti pro praktické firemní využití. 
Popsanými dosavadními kroky byla potvrzena reliabilita dotazníku, ale také potřeba vypuštění některých položek a přeuspořádání zbylých do nových faktorů. Tyto práce spočívající v několika iteracích exploratorní faktorové analýzy a v postupném vypouštění položek nekorespondujících s jednotlivými jasně odlišenými faktory vedly $\mathrm{k}$ 6faktorovému modelu a redukci dotazníku na 47 položek. Tak byla vytvořena nová verze dotazníku, která bude nyní distribuována reprezentativnímu vzorku respondentů.

Jakmile nové testování podstoupí cca 235 osob (což je 2.5násobek dvojnásobku současného počtu položek dotazníku) pak přistoupíme ke konfirmatorní faktorové analýze.

Dalším plánovaným krokem je realizace kontrastní validizace na firemních účastnících, kde chceme posuzovat, zda pracovníci, kteří jsou svým okolím vnímáni jako zvlášt' kreativní a inovativní, př́padně kteří vykonávají kreativní profese, skutečně budou v odpovídajících položkách dotazníku skórovat výše než jejich kolegové ze zbytku populace.

Dále budou probíhat další validizační studie porovnávající výsledky respondentů v našem dotazníku s jinými standardizovanými metodami (kresebnými testy kreativity, s relevantními položkami vybraných osobnostních dotazníků a testů sociálních kompetencí).

\section{Limity}

Nejvýraznějším limitem naší metody v aktuální podobě je zjišt'ování kreativity a inovativnosti pouhým dotazníkem/inventářem. I když Kaufman (2019) k tomu uvádí své pozorování, že sebehodnotící dotazníky nejsou sice ideální, ale dávají lepší výsledky, než bychom si mysleli.

Na základě faktorové analýzy bylo nutné odstranit některé nejednoznačné položky, které sytily více faktorů zároveň a zbylé přeuspořádat do nových 6 clusterů. Nyní nás čeká nový sběr dat na reprezentativním vzorku a řádné posouzení kontrastní validity porovnáním obecné populace s jedinci, kteří jsou známi svou vysokou kreativitou a inovativností a další relevantní validizační studie.

\section{Otázky}

V dalších studiích budeme muset důkladněji prokázat správnost našeho šestifaktorového modelu a oprávněnost odvozovat existenci jednoho kvocientu kreativity a inovativnosti reprezentovaného našimi šesti kompetencemi. Také je otázkou vhodnost používání sebehodnocení při testování kreativity a postupně bude zřejmě třeba hledat objektivnější metodu.

Nicméně předpokládáme, že po ověření konfirmatorní faktorovou analýzou a po náležitých validizačních studiích budeme moci začít dotazník používat ve firemních rozvojových programech a ověřit jeho schopnost měřit posuny jejich účastníků v kreativitě a inovativnosti dosažené během rozvojového programu. 


\section{Literatura}

Csikszentmihalyi, M. (1997). Creativity: Flow and the psychology of Discovery and invention. New York: Harper Perennial.

Franková, E. (2011). Kreativita a inovace v organizaci. Praha: Grada Publishing.

Guilford, J. P. (1950). Creativity. American Psychologist, 5, 444-454. https://doi.org/10.1037/h0063487

Jurčová, M. (1984). Torranceho figurálny test tvorivého myslenia - Príručka: Všeobecná čast'; Praktická čast’. Bratislava: Psychodiagnostické a didaktické testy.

Kaufman, J. C. (2019). Self-assessment of creativity: Not ideal, but better than you think. Psychology of Aesthetics, Creativity, and the Arts, 13(2), 187-192. https://doi.org/10.1037/aca0000217

Kaufman, J. C. \& Sternberg, R. J. (2010). The Cambridge Handbook of Creativity. Cambridge, New York: Cambridge university Press. https://doi.org/10.1017/CBO9780511763205

MacKinnon, D. W. (1975). The Nature and Nurture of Creative Talent. In: Barbre. W. B. \& Renzuli, J. S. (Eds.). Psychology and Education of the Gifted (pp. 151-167). New York: Irvington Publishers.

Petrowski, M. J. (2000). Creativity research: implications for teaching, learning and thinking. Reference Services Review, 28(4), 304-312. https://doi.org/10.1108/00907320010359623

Pritzker, S. R. \& Runco, M. A. (Eds.) (2011). Encyclopedia of Creativity. San Diego: Academic Press.

Schuler, H.\& Hell, B. (2014). ASK: Test deduktivního a kreativního myšlení-Přiručka. Praha: Hogrefe - Testcentrum.

Schürer, M. (1977). KREATOS: Projekčni kresebni test creativity a osobnosti-př́ručka pro administraci, vyhodnocení a interpretaci. Praha: Psychodiagnostické a didaktické testy.

Urban, K. K.\& Jellen, H. G.\& Kováč, T. (2002). Urbanův figurální test tvořivého myšlení. Brno: Psychodiagnostika.

\section{Korespondující autor}

Mgr. Ing. Milan Bobek, MSc.

Univerzita Karlova, Filozofická fakulta, Katedra psychologie

Celetná 20, 11642 Praha 1, Česká republika

milan.bobek@fbe.cz 


\title{
Attitudes towards migrants in the Slovak population based on Eurobarometerdata (2017)
}

\section{Postoje k migrantom v slovenskej populácií na základe údajov Eurobarometra (2017)}

Miroslava Bozogáňovál, \& Tatiana Lorincová ${ }^{2}$

${ }^{1}$ Spoločenskovedný ústav CSPV Slovenskej akadémie vied, Košice, Slovensko

${ }^{2}$ Prešovská univerzita v Prě̌ove, Fakulta manažmentu, Katedra manažérskej psychológie, Slovensko

\begin{abstract}
The opinion of the Slovak population is based on the assumption that there are hundreds of refugees in our country. In 2018, 37 persons were granted international protection (MÚ MV $S R, 2019)$.
\end{abstract}

Objectives. The goal of this study is to analyze attitudes towards migrants by gender, employment and perceived social class.

Method. The research sample consisted of 1080 respondents in the SR - 43.1\% men and 56.9\% women of the age of 15 - 93 years $(M=49.45$, SD=16.83).). Data collection was carried out in a face-to-face interview in the (2017) form of multi-stage probabilistic selection in Eurobarometer 88.2 (2017). Attitudes toward migrants were measured by a 7-item scale $($ Cronbach $=0.861)$. We used descriptive analysis, Student t-test for two independent samples, Mann-Whitney U-test and one-way analysis of variance.

Results. It was found that women do not differ from men in attitudes towards migrants, employed do not differ from unemployed and respondents from working social class have more negative attitudes towards migrants than respondents in higher classes.

Conclusion. The paper provides insight into attitudes towards migrants in the Slovak population. We used the data which are currently the most up-to-date source of this information (April 2018) and provide opportunities for further research.

Limits. The nature of the data does not allow us to examine the psychological characteristics of respondents in more detail.

Keywords. migrants; attitudes; Eurobarometer; social class

https://doi.org/10.5817/CZ.MUNI.P210-9488-2019-9 


\begin{abstract}
Abstrakt
Názor obyvatel'ov SR je založený na predpoklade, že sa u nás nachádzajú stovky utečencov. V roku 2018 bola medzinárodná ochrana poskytnutá 37 osobám (MÚ MV SR, 2019).
\end{abstract}

Ciel': Ciel'om príspevku je analyzovat' postoje k migrantom na základe rodu, zamestnania a vnímanej sociálnej triedy.

Metódy. Výskumný súbor tvorilo 1080 respondentov $S R-43.1 \%$ mužov a $56.9 \%$ žien vo veku 15 - 93 rokov $(M=49.45, S D=16.83)$. Zber dát prebiehal spôsobom Face-to-face v rámci Eurobarometer 88.2 (2017) formou viacstupňového probabilistického výberu. Postoje $k$ migrantom boli merané 7 položkovou škálou (Cronbach =0,861). Použili sme deskriptívne analýzy, Studentov t-test pre dva nezávisle výbery, Mann-Whitney U-test a jednovchodovú analýzu rozptylu.

Výsledky. Ukázalo sa, že ženy sa neodlišujú od mužov v ich postojoch k migrantom, zamestnaní sa neodlišujú od nezamestnaných a respondenti robotnickej triedy majú k migrantom negatívnejšie postoje ako respondenti vyššich sociálnych tried.

Záver. Príspevok poskytuje pohl'ad na postoje k migrantom na slovenskej populácii. Použité dáta sú v súčasnosti najaktuálnejším zdrojom týchto informácií (april 2018) a poskytujú príležitosti pre d’alšie skúmanie.

Limity. Charakter dát nám neumožňuje detailnejšie skúmanie psychologických charakteristík respondentov.

Kl’účové slová. migranti; postoje; Eurobarometer; sociálna trieda

\title{
Teoretické východiská
}

Európske krajiny sú vystavené prílivu žiadatel’ov o azyl vel'mi heterogénne, napr. Nemecko a Švédsko spracováva vel'ké množstvo žiadostí na osobu, zatial' čo Spojené král'ovstvo a Česká republika zdiel'ajú ovel'a menšiu zodpovednost'. Na Slovensku panuje názor, že sa tu nachádzajú stovky/tisíce utečencov. V roku 2017 Slovenská republika udelila azyl 29 osobám (IOM, 2018) a v roku 2018 bolo zaznamenaných 178 žiadostí o azyl, pričom medzinárodná ochrana bola poskytnutá 37 osobám (MÚ MV SR, 2019).

Stále prebieha diskusia o vhodnom pomenovaní migrantov (utečenci; ne/dobrovol'ní, i/legálni migranti), kde podl'a dohody OSN, pojem migrant pokrýva všetky prípady, kde rozhodnutie migrovat' bolo prijaté slobodne daným jednotlivcom. Pojem zahŕňa heterogénne kategórie vo verejných a politických debatách (Moses, 2006; Verkuyten, Mepham \& Kros, 2018). Podl'a výsledkov reprezentatívneho výskumu IOM o postojoch verejnosti k zahraničnej migrácii a migrantom v Slovenskej republike, majú obyvatelia Slovenska relatívne málo osobných skúseností s migrantmi a majú málo znalostí o migrantoch, ktoré si často vytvárajú podl'a informácií z médií. Domáce obyvatel'stvo sa obáva, že na Slovensku žije vysoký počet migrantov, ktorí berú pracovné miesta Slovákom, rozširujú nebezpečné choroby, sú ekonomickou zát'ažou pre štátny rozpočet, a že kriminalita migrantov môže postupne narastat'. Migranti sú vnímaní ako ohrozenie pre domácu populáciu a tento pocit ohrozenia generuje 
d'alšie predsudky (Vašečka, 2009). Tieto presvedčenia majú negatívny dopad na postoje voči migrantom, nie len na teoretickej úrovni, ale aj na behaviorálnej - ide napríklad o extrémne pravicové strany mobilizujúce občanov v otázkach azylu, útoky na azylové centrá, čiastočné uzavretie Schengenských hraníc, etnocentrizmus, marginalizácia, segregácia a pod. (Moses, 2006; Verkuyten et al., 2018).

Murray a Marx (2013) uviedli, že v rámci výskumu migrantov a migrácie ide najmä o ohrozenie „domácich“ z hl'adiska ekonomiky, kultúrnych a sociálnych záujmov, čo v rámci pomysleného boja o ,zdroje“ môže viest’ k negatívnym postojom voči migrantom. Orak a Solakoglu (2016) píšu o dvoch základných smeroch vo výskume postojov k migrantom - prvom z pohl'adu ekonomických faktorov a druhom, ktorý sa sústredí na neekonomické faktory ako sú napr. osobnostné, kultúrne, náboženské a politické faktory. Výskum v oblasti migrácie demonštruje, že postoje k migrantom sú sčasti skupinovo špecifické a závislé na kultúrnej podobnosti migrantov, vzdelanostnej úrovni a pracovných zručnostiach (Helbling \& Kriesi, 2014), jazyku a farbe pleti (Hopkins, 2015), národného pôvodu (Hainmueller \& Hangartner, 2013), ekonomickom prínose a náboženstve (Bansak, Hainmueller \& Hangartner, 2016).

Vo výskumoch venujúcim sa efektu rodu na postoje $\mathrm{k}$ migrantom sú výsledky nejednoznačné. Ponce (2017) uvádza, že neexistuje dôkaz o vyššej miere xenofóbie u mužov ako u žien. Existujú však prípady, kde sa u žien ukazujú negatívnejšie postoje k migrantom ako u mužov, najmä ak ide o moslimských migrantov. Dôležité je poznamenat' aj to, že obdobie, kedy sú výskumy konané ovplyvňuje postoje k migrantom. Ďalej uvádza, že negatívne postoje voči „ekonomickým“ migrantom sú častejšie u mužov. Ponce (2017) poskytuje prehl’ad výsledkov efektu rodu na postoje $\mathrm{k}$ migrantom v rámci medzinárodných štúdií. Hellwig a Sinno (2016) zdôrazňujú potrebu rozlišovania typu migrantov vzhl'adom na postoje $\mathrm{k}$ nim (schopnosti, náboženstvo, dobrovol'nost' migrácie, hodnoty). Ekonomický kontext je možným vysvetlením rozdielnych postojov medzi rodmi - ženy sú na trhu práce zranitel’nejšie ako muži a preto si robia viac starostí vzhl'adom na dôsledky migrácie, pretože tá môže ovplyvnit' trh práce a tým pádom aj udržatel'nost' sociálneho štátu (Chafetz, 2006).

Podl'a teórie etnickej sút'aže, tí jedinci, ktorí sú sociálne zranitel’ní budú pravdepodobnejšie sút'ažit's migrantmi o zdroje a budú ich vnímat' ako hrozbu. Títo jedinci sa odlišujú od ostatnej populácie $\mathrm{v}$ tom, ako sú vystavení rôznym informáciám a afektívnej kategorizácii migrantov. Vzhl’adom k sociálnej pozícii a štruktúre sa dá očakávat', že riziko kontaktu s migrantom aktivuje rôzne úrovne pozornosti a obáv v tejto oblasti (Zaller, 1992).

\section{Metóda}

\section{Ciel' a hypotézy}

Ciel'om príspevku bolo analyzovat' postoje $\mathrm{k}$ migrantom v kontexte vybraných sociodemografických charakteristík. Migranti sú podl'a Eurobarometra (2017): „l’udia, ktorí sa narodili mimo EÚ, opustili svoju rodnú krajinu a $\mathrm{v}$ súčasnosti sa legálne zdržiavajú na Slovensku“. Postoje k migrantom sme porovnávali na základe rodu, zamestnania a vnímanej sociálnej triedy respondentov. 
Na základe teoretických východísk sme si stanovili výskumné otázky:

1. Existujú rozdiely medzi mužmi a ženami v postojoch k migrantom?

2. Existujú rozdiely medzi zamestnanými a nezamestnanými v postojoch $\mathrm{k}$ migrantom?

3. Existujú rozdiely medzi respondentmi rôznych sociálnych tried v postojoch k migrantom?

\section{Výskumný súbor}

Analyzovaný výskumný súbor tvorilo 1080 respondentov (Eurobarometer 88.2, 2017) SR $-43.1 \%$ mužov a $56.9 \%$ žien vo veku 15 - 93 rokov $(\mathrm{M}=49.45, \mathrm{SD}=16.83)$. Zber dát prebiehal v októbri 2017 formou Face-to-face interview v rámci Eurobarometer 88.2 (2017) formou viacstupňového probabilistického výberu, ktorý v rámci SR vykonala agentúra TNS Slovakia, Bratislava. Dáta a dotazník sú vol'ne dostupné na stráne https://www.gesis.org/eurobarometerdata-service/search-data-access - ZA6927: Eurobarometer 88.2 (2017). Sociodemografické charakteristiky výskumného súboru sú uvedené v tabul'ke 1.

Tabul'ka 1. Socio-demografické charakteristiky výskumného súboru

\begin{tabular}{|c|c|c|c|c|c|c|c|}
\hline Rod & $\%$ & Vek & $\%$ & Vzdelanie & $\%$ & Pracovný status & $\%$ \\
\hline Muž & 43.1 & $15-24$ & 8.2 & $\begin{array}{l}\text { do } 15 \\
\text { rokov }\end{array}$ & 6.7 & Podnikatel'/živnostník & 6.7 \\
\hline \multirow[t]{7}{*}{ Žena } & 56.9 & $25-39$ & 24.1 & $\begin{array}{l}16-19 \\
\text { rokov }\end{array}$ & 69.4 & Manažér & 7.3 \\
\hline & & $40-54$ & 26.2 & $\begin{array}{l}20 \text { a viac } \\
\text { rokov }\end{array}$ & 17.9 & Úradníci & 17.6 \\
\hline & & 55 a viac & 41.5 & & & Manuálny pracovníci & 25.6 \\
\hline & & & & & & Osoba v domácnosti & 1.6 \\
\hline & & & & & & Nezamestnaní & 8.1 \\
\hline & & & & & & Dôchodcovia & 28.4 \\
\hline & & & & & & Študenti & 4.6 \\
\hline
\end{tabular}

\section{Metodika}

Položky, s ktorými sme v rámci štúdie pracovali, pochádzajú z hlavného dotazníka Eurobarometer 88.2 (2017) - čast' Integrácia migrantov v Európskej únii. Postoje respondentov k migrantom boli merané 7-položkovou škálou od 1 - rozhodne súhlasím po 4 - rozhodne nesúhlasím (Cronbachova alpha $=0,861$ ). Položky sa týkali tak ekonomických faktorov (napr. „,Prist'ahovalci vo všeobecnosti majú celkovo pozitívny vplyv na slovenskú ekonomiku. "), ako aj neekonomických faktorov (napr. ... ,obohacujú slovenský kultúrny život (umenie, hudba, jedlo a pod. "). Pozitívne ladené položky boli prekódované - vyššie skóre znamená pozitívnejší postoj. Pre určenie dimenzionality dát sme použili faktorovú analýzu - metódu principal axis 
factoring (Kaiser-Meyer-Olkin $=.852$; Bartlett's Test of Sphericity $\mathrm{X}^{2}=2912.671 ; \mathrm{df}=21 ; \mathrm{p}<$ .01), kde boli vyextrahované dva faktory. Prvý faktor sme pomenovali „Migranti ako pomoc“ $($ Cronbachova alpha $=.882)$ a druhý faktor „Migranti ako zát’až“ (Cronbachova alpha = .814). Rotovaná matica a konkrétne znenie položiek je uvedená v tabul'ke 2.

Tabul'ka 2. Rotovaná faktorová matica

\begin{tabular}{lcc}
\hline \multicolumn{1}{c}{ Migranti... } & \multicolumn{2}{c}{ Faktor } \\
& $\mathbf{1}$ & $\mathbf{2}$ \\
\hline ...prinášajú nové nápady a/alebo podnecujú inovácie na Slovensku. &, 817 \\
...majú celkovo pozitívny vplyv na slovenskú ekonomiku. &, 794 \\
...obohacujú slovenský kultúrny život (umenie, hudba, jedlo a pod.). &, 778 \\
$\begin{array}{l}\text {...pomáhajú obsadit' pracovné miesta, na ktoré na Slovensku t'ažko nájst' } \\
\text { pracovníkov. }\end{array}$ &, 746 \\
$\begin{array}{l}\text {...sú zát'ažou pre náš sociálny systém. } \\
\text {...zhoršujú problémy s kriminalitou na Slovensku. }\end{array}$ &, 815 \\
...berú prácu pracovníkom na Slovensku. &, 734 \\
\hline
\end{tabular}

\section{Štatistická analýza}

Pre účely spracovania dát sme použili deskriptívne analýzy, Studentov t-test pre dva nezávisle výbery, Mann- Whitney U-test a jednovchodovú analýzu rozptylu. Pri použití jednotlivých testov sme rešpektovali podmienky použitia (Pallant, 2016; Field, 2017). Dáta boli spracovávané v programe IBM SPSS Statistics v21 a JASP v 0.11.1. V rámci datasetu sa vyskytujú chýbajúce dáta (respondent neodpovedal), preto uvádzame aj počet respondentov zahrnutých do jednotlivých analýz.

\section{Výsledky}

Pre porovnanie postojov k migrantom na základe rodu (výskumná otázka 1) sme použili Studentov t-test pre dva nezávisle výbery. Výsledky sú uvedené v tabul'ke 3.

Ukázalo sa, že existujú štatisticky významné rozdiely medzi mužmi a ženami v postojoch. $\mathrm{V}$ rámci výrokov, ktoré sa týkali migrantov ako pomoci $(\mathrm{t}(826)=-2.775, \mathrm{p}<0.01)$, ženy viac súhlasili s pozitívnymi výrokmi $(\mathrm{M}=9.300, \mathrm{SD}=3.060) \mathrm{k}$ migrantom ako muži $(\mathrm{M}=8.699$, $\mathrm{SD}=3.159)$ so slabým efektom $(\mathrm{d}=-0.194)$. V rámci postojov voči migrantom, ktoré považujú migrantov za zát’až sa rozdiely medzi mužmi a ženami nepreukázali $(\mathrm{p}>0.05)$. Na základe týchto výsledkov môžeme konštatovat', že medzi mužmi a ženami v rámci Slovenskej republiky neexistujú rozdiely v postojoch k migrantom (aj napriek tomu, že v prvom prípade sa rozdiely preukázali, sila efektu je slabá). 
Tabul'ka 2. Porovnanie postojov $k$ migrantom u mužov a žien (Studentov t-test pre dva nezávisle výbery)

\begin{tabular}{ccccccccc}
\hline Postoje & Rod & N & Priemer & SD & t & df & p & d \\
\hline $\begin{array}{c}\text { Migranti } \\
\text { ako }\end{array}$ & Muži & 375 & 8.699 & 3.159 & & & & \\
pomoc & Ženy & 453 & 9.300 & 3.060 & -2.775 & 826 & 0.006 & -0.194 \\
$\begin{array}{c}\text { Migranti } \\
\text { ako zátaž }\end{array}$ & Muži & 405 & 6.109 & 2.346 & & & & \\
\hline
\end{tabular}

Ďalej sme porovnávali postoje medzi zárobkovo činnými respondentmi a respondentmi, ktorí sú nezamestnaní. K zamestnaným respondentom sme zaradili tých, ktorí patria medzi podnikatel'ov/živnostníkov, manažérov, úradníkov a manuálnych pracovníkov (vid' tabul'ku 1). Študentov, dôchodcov a osoby v domácnosti sme pre účely analýz vynechali. Použili sme Mann-Whitney U-test.

Tabul'ka 3. Porovnanie postojov $k$ migrantom u zamestnaných a nezamestnaných (MannWhitney $U$-test)

\begin{tabular}{cccccccc}
\hline Postoje & Práca & N & Priemer & SD & W & p & g \\
\hline Migranti ako & zamestnaní & 487 & 9.226 & 3.221 & \multirow{2}{*}{0428.000} & 0.002 & 0.234 \\
pomoc & nezamestnaní & 68 & 8.103 & 2.760 & & & \\
Migranti ako & zamestnaní & 526 & 6.183 & 2.362 & & & \\
zát’až & nezamestnaní & 73 & 6.438 & 2.309 & & & \\
\end{tabular}

${ }^{*} \mathrm{p}<0,05$

$\mathrm{Na}$ základe výsledkov sa nám preukázali štatisticky významné rozdiely medzi zamestnanými a nezamestnanými v rámci subškály „Migranti ako pomoc“ (W=20428.000; p < 0.01 ) so slabým efektom (Hedgesovo $g=0.234$ ). V subškále „Migranti ako zát’až“ sa rozdiely medzi zamestnanými a nezamestnanými respondentmi nepreukázali ( $\mathrm{p}>0.05)$. Môžeme konštatovat', že medzi zamestnanými a nezamestnanými v rámci Slovenskej republiky neexistujú rozdiely $\mathrm{v}$ postojoch $\mathrm{k}$ migrantom (aj napriek tomu, že v prvom prípade sa rozdiely preukázali, sila efektu je slabá).

Napokon, jednovchodová analýza rozptylu bola vykonaná za účelom porovnania postojov k migrantom u robotníckej triedy, nižšej strednej triedy a strednej a vysokej triedy. Respondenti sa k jednotlivým triedam priradzovali sami.

Výsledky preukázali signifikantný efekt vnímanej sociálnej triedy na postoje k migrantom („Migranti ako pomoc“) $[\mathrm{F}(2,801)=8.338$, p $<0.01]$ so slabým efektom $(\mathrm{f}=0.251)$. Tukey HSD post hoc test indikoval, že priemerné skóre postojov k migrantom sa signifikantne líši. Existujú rozdiely medzi robotníckou triedou $(\mathrm{M}=8.485, \mathrm{SD}=9.732)$ a nižšou strednou triedou $(\mathrm{M}=9.732, \mathrm{SD}=3.199, \mathrm{~d}=-0.394, \mathrm{p}<0.01)$, ale aj strednou a vy̌šsou triedou 
$(\mathrm{M}=9.108, \mathrm{SD}=3.011, \mathrm{~d}=-0.203, \mathrm{p}<0.05)$. Výsledky ukazujú, že respondenti, ktorí sa zaradili do robotníckej triedy majú negatívnejší postoj k migrantom v rámci subškály „Migranti ako pomoc" ako respondenti ostatných tried. Výsledky sú znázornené na obrázku 1. V rámci subškály „Migranti ako zát’až“ sa rozdiely nepreukázali $[\mathrm{F}(2,884)=1.870, \mathrm{p}>0.05]$.

\section{Obrázok 1. Vnímaná sociálna trieda a postoje k migrantom}

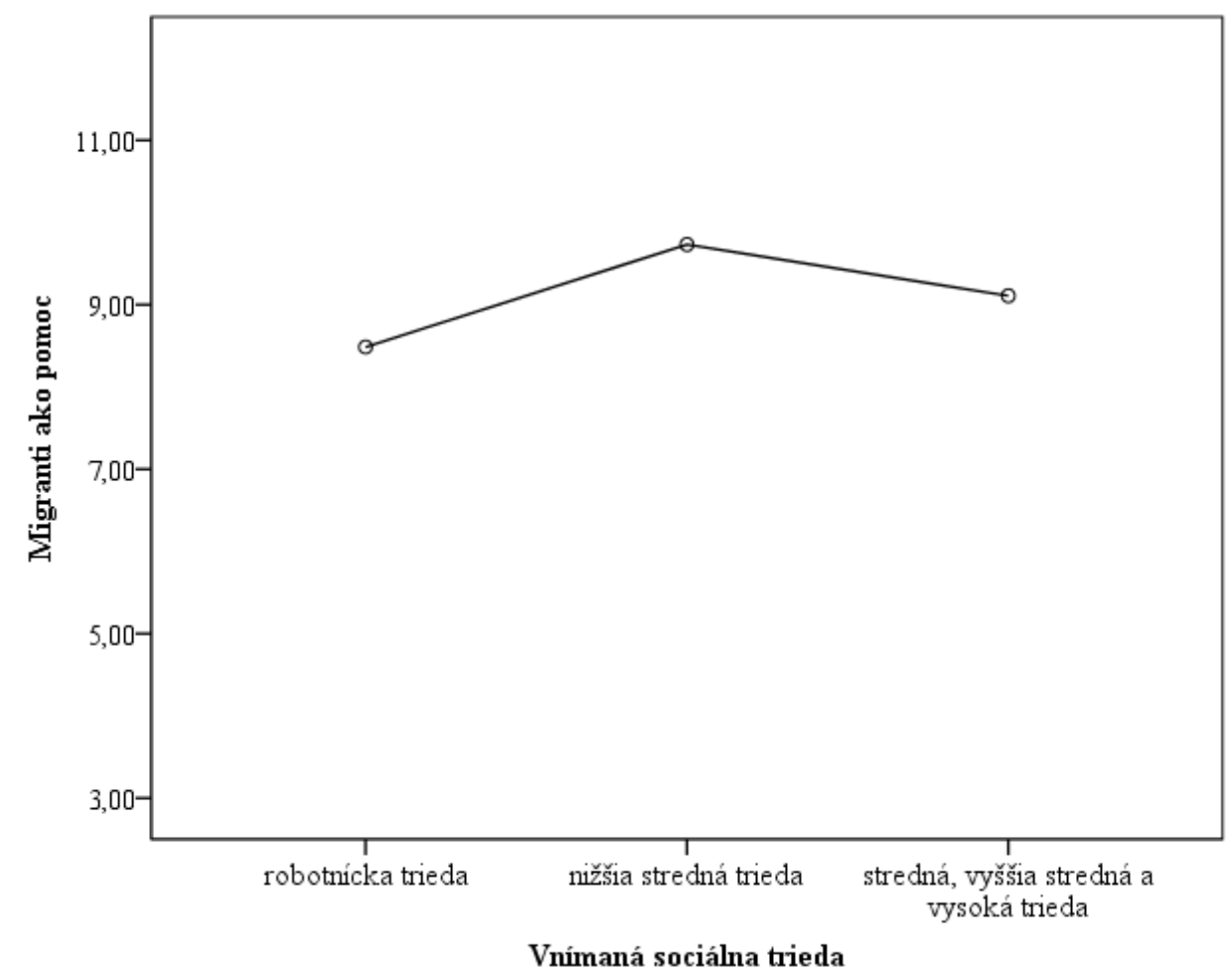

\section{Diskusia}

Príspevok sa zaoberá problematikou postojov k migrantom v rámci slovenskej populácie. Analyzované dáta sú v súčasnosti najaktuálnejším zdrojom týchto informácií (zverejnené v apríli 2018) a poskytujú príležitosti pre d’alšie skúmanie témy. V rámci príspevku bola vykonaná komparácia mužov a žien v oblasti postojov k migrantom, kde bolo zistené, že ženy sa vo svojich postojoch od mužov v zásade nelíšia, tak ako uvádza Ponce (2017). Naše zistenie si vysvetl'ujeme ako dôsledok použitej metodiky a dát. Migrant je v Eurobarometri 88.2 (2017) definovaný ako človek, ktorý sa narodil mimo EÚ, opustil svoju rodnú krajinu a v súčasnosti sa legálne zdržiava na Slovensku. V tomto kontexte nie je explicitne stanovené, či sa jedná o moslimského migranta, migranta z východnej Európy a pod. Na základe výsledkov Ponceho výskumu (2017), ženy majú negatívnejšie postoje k moslimským migrantom - v našom výskume nebol daný „typ“ migranta zadefinovaný, preto si respondenti mohli pod týmto pojmom predstavit' kohokol'vek. Autori Dion a Dion (in Berry, 2001) poukazujú na dôležitost' rodu $\mathrm{v}$ rámci porozumenia migrantom a $\mathrm{v}$ rámci adaptácie migrantov v prijímajúcej spoločnosti. Napr. sociálna štruktúra faktorov a hodnôt vzt’ahujúcich sa k rodinným vzt'ahom môže viest' k odlišnej skúsenosti tak pre mužov, ako aj pre ženy. Rodové charakteristiky vo významnej miere 
súvisia so samotným postojom k migrácii (Berry, 2001). Postoje by bolo vhodné porovnávat' aj s ohl'adom na kultúrne, náboženské a hodnotové orientácie migrantov.

Komparácia respondentov z hl'adiska zamestnanosti nepreukázala rozdiely v postojoch. Zamestnanost' sme $\mathrm{v}$ našom výskume vnímali ako charakteristiku sociálnej zranitel'nosti (nezamestnaný človek je sociálne zranitel'nejší ako ten, ktorý pracuje). Absencia rozdielov v postojoch môže byt' spôsobená aj nepomerom skupiny zamestnaných a nezamestnaných. Ďalšou z charakteristík sociálnej zranitel'nosti je v našom výskume vnímaná sociálna trieda, kde podl'a teórie etnickej sút'aže je nižšia sociálna trieda spojená s väčšou pravdepodobnost'ou sút’aženia o zdroje s populáciou migrantov (Zaller, 1992). V tomto prípade sa ukázalo, že respondenti, ktorí sa zaradili do robotníckej triedy, majú k migrantom negatívnejší postoj ako tí, ktorí sa zaradili do vyšších tried. Ostatné skupiny sa od seba vzájomne neodlišovali. Môžeme predpokladat', že zástupcovia robotníckej triedy pracujú na menej kvalifikovaných miestach, kde by ich migranti mohli l'ahšie nahradit' a tak vnímajú túto ekonomickú hrozbu viac ako ostatné triedy (nižšia, stredná, vysoká).

Limitom výskumu je spôsob merania postojov k migrantom. Rozdelenie postojov na ekonomické a neekonomické faktory by mohlo priniest' spol'ahlivejšie výsledky. Ďalej je to všeobecná definícia pojmu migrant $\mathrm{v}$ rámci Eurobarometra 88.2 (2017), ktorá otvára respondentom možnost’ rôznych predstáv „migranta“, pri odpovediach na položky dotazníka.

Hlavným prínosom výskumu je základný prehl'ad informácií o postojoch $\mathrm{k}$ migrantov u slovenskej populácie na výskumnom súbore, ktorý sa približuje charakteristikám reprezentatívnej vzorky respondentov Slovenskej republiky (zber dát prebehol podl'a štandardov Eurobarometra). Naše zistenia môžu pomôct' pri pochopení toho, ako odlišne vnímajú rôzne sociálne triedy populáciu migrantov. Uvedené zistenia by bolo vhodné skúmat' hlbšie, čo ale charakter dát neumožňuje v potrebnej miere. Zaujímavá by mohla byt' komparácia takých respondentov, ktorí neodpovedali na položky týkajúce sa migrantov s tými, ktorí odpovedali.

\section{Záver}

Migrácia a migranti sú diskutovanou témou v kontexte viacerých vedných disciplín. V rámci príspevku boli porovnávané vybrané sociodemografické charakteristiky vzhl’adom na postoje k migrantom. Zistili sme, že muži a ženy, zamestnaní a nezamestnaní sa od seba v postojoch voči migrantom neodlišujú, ich postoje sú podobné. Robotnícka sociálna trieda vníma migrantov negatívnejšie ako zástupcovia, ktorí sa zaradili do vyšších sociálnych tried. Názory a postoje k migrantom sú dôležitou súčast’ou akulturácie tak z psychologického, ako aj sociálneho hl'adiska. Na základe toho je možné konštatovat', že výskum v oblasti migrantov a migrácie má svoje opodstatnenie aj v budúcnosti. 


\section{Literatúra}

Bansak, K., Hainmueller, J.,\& Hangartner, D. (2016). How economic, humanitarian, and religious concerns shape European attitudes toward asylum seekers. Science, 354(6309), 217-222. http://doi.org/10.1126/science.aag2147

Berry, W. J. (2001). A Psychology of Immigration. Journal of Social Issues, 57(3), 615-631. http://doi.org/10.1111/0022-4537.00231

Eurobarometer 88.2:European Commission, Brussels. (2018). TNS opinion, Brussels [producer]. GESIS Data Archive, Cologne. ZA6927 DatafileVersion 1.0.0, http://doi.org/10.4232/1.13005

Hainmueller, J., \& Hangartner, D. (2013). Who Gets a Swiss Passport? A Natural Experiment in Immigrant Discrimination. American Political Science Review, 107(1):159-187. http://doi.org/10.1017/S0003055412000494

Helbling, M., \& Kriesi H. (2014). Why Citizens Prefer High- over Low-Skilled Immigrants: Labour Market Competition, Welfare State, and Deservingness. European Sociological Review, 30(5), 595-614. http://doi.org/10.1093/esr/jcu061

Hopkins, D. J. (2015). The Upside of Accents: Language, Inter-group Difference, and Attitudes Toward Immigration. British Journal of Political Science, 45(3), 531-557. http://doi.org/10.1017/S0007123413000483

Chafetz, J. S. (Ed.). (2006). Handbook of the Sociology of Gender. Springer Science \& Business Media.

IOM. (2018). Migrácia na Slovensku. Medzinárodná organizácia pre migráciu. Dostupné z: https://iom.sk/sk/migracia/migracia-na-slovensku.html

Moses, J. (2006). International Migration: Globalization's Last Frontier. London: ZedBooks.

MÚ MV SR. (2019). Ministerstvo vnútra Slovenskej republiky. Azyl a migrácia - štatistiky.

Dostupné z: https://www.minv.sk/?statistiky-20

Murray, K. E., \& Marx M. D. (2013). Attitudes toward Unauthorized Immigrants, Authorized Immigrants, and Refugees. Cultural Diversity and Ethnic Minority Psychology, 19(3), 332-341. http://doi.org/10.1037/a0030812

Orak, U., \& Solakoglu, O. (2016). A Comparative Analysis of Attitudes Toward Immigrants. International Journal of Crimiology and Sociology, 5, 143-153. http://doi.org/10.6000/1929-4409.2016.05.13

Ponce, A. (2017). Gender and anti-immigrant attitudes in Europe. Socius, 3, 1-17. http://doi.org/10.1177/2378023117729970

Štatistický úrad SR. (2019). Stav obyvatel'stva v SR k 31. decembru 2018. Dostupné z: https://slovak.statistics.sk/wps/portal/ext/products/informationmessages/inf_sprava_detail/ $\underline{535}$

Verkuyten M., Mepham, K. \& Kros, M. (2018). Public attitudes towards support for migrants: the importance of perceived voluntary and involuntary migration, Ethnic and Racial Studies, 41(5), 1-918, http://doi.org/10.1080/01419870.2017.1367021

Vašečka, M. (2009). Postoje verejnosti k cudzincom a zahraničnej migrácii v Slovenskej republike. Medzinárodná organizácia pre migráciu.

Zaller, J. R. (1992). The nature and origins of mass opinion. New York, NY, US: Cambridge University Press. http://doi.org/10.1017/CBO978051181869 


\section{Korespondující autor}

Mgr. Miroslava Bozogáňová, PhD.

Spoločenskovedný ústav CSPV SAV

Karpatská 5, 04001 Košice, Slovenská republika

bozoganova@saske.sk

Grantová podpora: Tento výskum bol podporený grantom VEGA 2/0068/19: Postoje voči migrantom v sociálno-psychologických kontextoch. 


\title{
Assessment of bossing and mobbing manifestations in the context of personality traits of employees
}

Posudzovanie prejavov bossingu a mobbingu v kontexte osobnostných čŕt zamestnancov

Miroslav Frankovský ${ }^{1}$, Zuzana Birknerová ${ }^{1} \&$ Milan Droppa $^{1,2}$

${ }^{1}$ Katedra manažérskej psychológie, Fakulta manažmentu, Prešovská univerzita v Prešove, Slovensko

${ }^{2}$ Katedra manažmentu, Pedagogická fakulta, Katolícka univerzita v Ružomberku, Slovensko

\begin{abstract}
Objectives. Bossing is a specific form of mobbing as a long-term, systematic negative influence of the superior towards the subordinates. In terms of operationalization of this construct, the original BOSSING methodology is presented in the paper.

Methods. The NAQ-Negative Acts Questionnaire methodologies were used to detect mobbing manifestations and the B5 questionnaire enabling the personality traits to be specified in terms of the Big Five concept. Based on the data obtained from the research sample of 636 employees, the paper presents the results of the validation of the BOSSING methodology, which was carried out using the NAQ methodology.
\end{abstract}

Results. The overall NAQ score correlated statistically significantly with both factors - WorkAimed Bossing (0,267) and Psyche-Aimed Bossing (0,117). Basic psychometric characteristics of the methodology and content specification of extracted factors Work-Aimed Bossing (Cronbach alpha-0,926) and Psyche-Aimed Bossing (Cronbach alpha-0,813) are presented. The research findings supported a multidimensional understanding of the bossing construct. Conclusion. The results of the correlation analysis between employees' personality traits and the assessment of bossing and mobbing prove the fact that the more the employees consider themselves as extraverted, open, friendly and conscientious, the less sensitive they perceive the occurrence of bossing and mobbing. Applying the BOSSING methodology in practice can contribute to identifying bossing manifestations in various work contexts.

Limits. The limiting factors of interpretation and generalization of the results are related to a limited research sample, taking into account cultural contexts and situational conditions of perception of bossing manifestations. At the same time, it is necessary to draw attention to the determination of the line between bossing and normal, though strict behaviour of a superior.

Keywords. bossing; mobbing; personality traits, BOSSING methodology; NAQ methodology

https://doi.org/10.5817/CZ.MUNI.P210-9488-2019-10 


\begin{abstract}
Abstrakt
Ciel'e. Bossing predstavuje špecifickú formu mobbingu ako dlhodobého, systematického negatívneho pôsobenia nadriadeného smerom k podriadeným. Z hl'adiska operacionalizácie tohto konštruktu je v príspevku prezentovaná pôvodná metodika BOSSING.
\end{abstract}

Metódy. Zároveň boli použité metodiky NAQ - Negative Acts Questionnaire na zistovanie prejavov mobbingu a dotazník B5 umožňujúci špecifikovat' osobnostné črty z hl'adiska konceptu Big Five. Na základe údajov získaných od výskumného súboru 636 zamestnancov sú v príspevku prezentované výsledky validizácie metodiky BOSSING, ktorá bola uskutočnená pomocou metodiky $N A Q$.

Výsledky. Celkové skóre metodiky NAQ štatisticky významne korelovalo tak s faktorom Bossing zameraný na prácu (0,267), ako aj s faktorom Bossing zameraný na psychiku $(0,117)$. Uvedené sú základné psychometrické charakteristiky metodiky a obsahová špecifikácia extrahovaných faktorov Bossing zameraný na prácu (Cronbachova alpha -0,926) a Bossing zameraný na psychiku (Cronbachova alpha - 0,813). Výskumné zistenia podporili multidimenzionálne chápanie konštruktu bossing.

Závery. Výsledky korelačnej analýzy medzi osobnostnými črtami zamestnancov a posúdením bossingu a mobbingu svedčia o skutočnosti, že čím sa zamestnanci posúdili ako viac extravertovaní, otvorení, privetivi s svedomití, tým menej citlivo vnímajú výskyt prejavov bossingu a mobbingu. Aplikácia metodiky BOSSING môže v praxi prispiet’ k identifikácii prejavov bossingu $v$ rôznych kontextoch práce.

Limity. Limitujúce faktory interpretácie a zovšeobecnenia výsledkov súvisia s obmedzenou výskumnou vzorkou, zohl'adnením kultúrnych kontextov a situačných podmienok vnímania prejavov bossingu. Zároveň je potrebné upozornit' na vymedzenie hranice medzi bossingom a normálnym, aj ked' tvrdým správaním nadriadeného.

Kl’účové slová: bossing; mobbing; osobnostné črty, metodika BOSSING; metodika NAQ

\title{
Úvod
}

L’udia, predovšetkým ekonomicky aktívni, trávia podstatnú čast' svojho života v práci, v konkrétnom pracovnom prostredí. Vzt’ahy medzi zamestnancami sú základným prvkom každej firemnej kultúry. Priaznivá klíma a dobré vzt’ahy medzi l’ud’mi v organizácii zabezpečujú viac času a síl, ktoré je možné venovat' pracovným povinnostiam (Birknerová, Frankovský, 2017). Pôsobenie pracovného prostredia je multidimenzionálne. Zahŕňa tak fyzikálne vplyvy, ako aj rôzne psychologické aspekty. V tomto kontexte do popredia vstupuje aj pôsobenie negatívnych sociálno-psychologických faktorov.

Viacerí autori (Bennett, 2000; Hafidz, 2012; Howladar et al., 2018) poukazujú na skutočnost', že tieto faktory poškodzujú produktivitu a sú v kontradikcii so záujmami organizácie. Majú tiež negatívny vplyv na konkrétnych zamestnancov, na ich psychické a fyzické zdravie. Za negatívne formy správania sa podl’a Skopalovej (2000) považujú všetky nežiaduce prejavy, ktoré sú v rozpore s očakávaniami, pravidlami, normami. Je to správanie, 
ktoré sa odchyl'uje od existujúcich noriem, predovšetkým morálnych a etických. Pri štúdiu nežiaduceho správania na pracovisku je rôznymi autormi používaná odlišná terminológia, napr. deviácie na pracovisku (Robinson, Bennett, 1995), kontraproduktívne pracovné správanie (Spector, Fox, 2002), ako aj antisociálne správanie, zlé správanie v organizácii, či dysfunkčné správanie. V tomto kontexte sa objavujú pojmy ako šikanovanie na pracovisku, mobbing, bossing (Einarsen, et al., 2011).

Mobbingu už od 80-tych rokov 20. storočia venuje pozornost' švédsky psychológ Leymann (1990), ktorý ho charakterizuje ako neprimerané ponižujúce správanie, pričom je vedená nepriatel'ská a neetická komunikácia, ktorú vykonáva jedna alebo viacero osôb smerom k inej vybranej osobe. Môže sa jednat' napr. o sociálne izolovanie, slovné napádanie, psychické týranie, šírenie zlej povesti (Zapf, Leymann, 1996). Podstatná čast' tejto široko koncipovanej definície má emocionálny kontext, na ktorý upozornili aj Görgülü et al. (2014). Títo autori vymedzili mobbing ako emocionálny útok, ktorý sa prejavuje neúctivým a škodlivým správaním.

Špecifickým, významne negatívnym sociálno-psychologickým prejavom na pracovisku je bossing, ktorý predstavuje vel'mi špecifickú formu mobbingu, pri ktorom je iniciátorom psychického nátlaku nadriadený (Borská, 2005).

Uvedená problematika má podl’a Hirigoyen (2000) dlhú históriu. Pri vymedzení bossingu je posudzované pravidelné a dlhodobé negatívne pôsobenie medzi nadriadeným a jeho zamestnancami. Aj Birknerová, Juhás a Litavcová (2010) uvádzajú ako hlavný znak bossingu systematickost' a dlhodobost'. Vystavenie takýmto systematickým, negatívnym a sociálnym aktom možno vnímat' ako typ psychologického obliehania. Leymann (1990) ho označil za psychologický teror, ktorý môže viest' k závažným fyzickým, psychickým a sociálnym problémom.

Z hl'adiska prejavov bossingu sa zamestnanec často ocitá v situácii, ktorá ho ohrozuje ovel'a viac než akákol'vek iná. Nejde len o spoločenské kontakty a pocit osobného št'astia, ale aj o odbornú identitu, kariéru a z ekonomického hl'adiska často aj o vlastnú existenciu (Huberová, 1995). Podl'a Olšovskej (2013) sa jedná o vedomé znižovanie dôstojnosti, zastrašovanie zamestnanca zo strany nadriadeného, následkom ktorého je duševné, morálne, fyzické alebo sociálne ublíženie. Ciel’om bossingu je narušenie pracovnej atmosféry pracovníka, poväčšine z dôvodu zdôraznenia svojho hierarchického postavenia v spoločnosti, udržania si moci, alebo z rôznych osobných záujmov voči zamestnancovi.

V kontexte prezentovaných zistení bola vo výskumnom projekte pozornost' sústredená na overenie hypotézy, $v$ rámci ktorej bola predpokladaná štatisticky významná súvislost' medzi vybranými osobnostnými črtami zamestnancov a posudzovaním prejavov bossingu a mobbingu.

\section{Metódy}

Ciel'om prezentovaného výskumu bolo obohatit' poznanie v oblasti operacionalizácie a konceptualizácie problematiky bossingu a mobbingu na základe posudzovania ich prejavov 
v kontexte osobnostných čŕt zamestnancov. Zároveň bolo ciel'om overit' pôvodnú metodiku posudzovania prejavov bossingu konštruovanú na báze multidimenzionálneho chápania tohto konštruktu. Výskumný súbor tvorilo 636 zamestnancov. Z hl'adiska rodu bolo vo výskumnej vzorke $392(62 \%)$ žien a 244 (38 \%) mužov. Priemerný vek respondentov bol 30,7 rokov (smerodajná odchýlka bola 10,237 rokov), vekové rozpätie bolo od 20 do 58 rokov. Priemerná dížka praxe bola 10,5 rokov (smerodajná odchýlka bola 10,090 rokov), rozpätie rokov dížky praxe bolo od 1 do 37 rokov. Stredoškolské vzdelanie malo $27 \%$ respondentov a vysokoškolské vzdelanie malo $73 \%$ respondentov. V súkromných organizáciách pracovalo $65 \%$ zamestnancov a vo verejnom sektore pracovalo $35 \%$ zamestnancov. Vo výskume bol použitý príležitostný výber respondentov.

Vo výskumnom projekte boli aplikované tri dotazníky, ktoré boli respondentom administrované skupinovo a anonymne. Uvedené dotazníky umožnili operacionalizovat' premennú mobbing (celkové skóre dotazníka NAQ), premennú bossing (Bossing zameraný na prácu a Bossing zameraný na psychiku) a premennú črta osobnosti (Extraverzia, Prívetivost', Svedomitost', Neurotizmus, Otvorenost').

Dotazník NAQ (Einarsen, Raknes, Matthiesen a Hellesøy, 1994) obsahuje 29 položiek, ktoré popisujú negatívne formy správania. Respondenti odpovedali, ako často sa stretli s uvedenými formami správania na pracovisku na škále od 1 do 5 (1 - nikdy; 2 - občas; 3 mesačne; 4 - týždenne; 5 - denne). Metodika je vyhodnotená jedným celkovým skóre, v rámci ktorého vyššia hodnota reprezentuje vyššiu mieru prejavov negatívneho správania na pracovisku. Metodika bola použitá ako preklad originálu.

Dotazník BOSSING (Frankovský a kol., 2019) bol v prezentovanom výskumnom projekte použitý ako pôvodná, originálna metóda autorov. Obsahuje 20 položiek, ktoré popisujú rôzne negatívne formy správania voči zamestnancovi zo strany nadriadeného. Respondenti odpovedali na škále od 1 do 5 (1 - úplne nesúhlasím; 2 - skôr nesúhlasím; 3 - ani súhlasím, ani nesúhlasím; 4 - skôr súhlasím; 5 - úplne súhlasím). Metodika umožňuje identifikovat' 2 faktory, ktoré vysvetl'ujú 54,9 \% variancie. Uvedené faktory je možné obsahovo špecifikovat' nasledovne:

- Bossing zameraný na prácu: Respondenti s vysokým skóre v danom faktore majú pocit, že ich nadriadený im nedovol'uje vyjadrit' sa ku kritike, nepozve ich na operatívne porady, neposkytne im priestor na vyslovenie svojho záujmu, neumožňuje im prístup k neskresleným informáciám na plnenie ich úloh, komunikuje s nimi minimálne, náhle ukončí rozhovor, ked’ vstúpia do miestnosti, šíri nepodložené tvrdenia, polopravdy a intrigy o nich, ignoruje ich názory a spochybňuje ich názory (Cronbachova alpha: 0,926).

- Bossing zameraný na psychiku: Respondenti, ktorí majú vysoké skóre v danom faktore sa domnievajú, že ich nadriadený kritizuje za ich politické, náboženské a iné presvedčenie, že nadriadený poškodzuje ich veci a výsledky ich práce, ohrozuje ich fyzickým násilím, sexuálne ich obt’ažuje, spochybňuje ich duševný stav, dáva im hanlivé prezývky (Cronbachova alpha: 0,813). 
Dotazník B5: skrátená verzia Big Five (Janovská, 2011) pozostáva zo 40-tich vlastností, ktoré sú posudzované na 8-bodovej škále (1 - úplne nepresne; 2 - vel'mi nepresne; 3 - pomerne nepresne; 4 - trochu nepresne; 5 - trochu presne; 6 - pomerne presne; 7 - vel'mi presne; 8 úplne presne). Vlastnosti sú v dotazníku usporiadané nezávisle a spadajú do piatich subškál:

- Extraverzia (veselý, extrovertný, čulý, kamarátsky, nadšený, priatel'ský, spoločenský)

- Prívetivost' (dobrosrdečný, láskavý, nežný, citlivý, ústretový, nápomocný, vl'údny, súcitný)

- Svedomitost' (svedomitý, dôkladný, poriadny, usporiadaný, pokorný, pedantný, spol'ahlivý, sebadisciplinovaný)

- Neurotizmus (napätý, neuvol’nený, nevyrovnaný, ustarostený, precitlivený, nervózny, nesebaistý)

- Otvorenost' (nekonvenčný, abstraktne mysliaci, híbavý, sčítaný, premýšl'avý, zaujímajúci sa, pátrajúci, vynachádzavý)

\section{Výsledky}

Na základe výsledkov testovania normality rozloženia získaných údajov (použité boli šikmost' a špicatost') sa nepotvrdilo normálne rozloženie. Pri analýze súvislostí boli použité neparametrické metódy, konkrétne Spearmanov korelačný koeficient (tabul'ka 1).

Tabul'ka 1. Test normality rozloženie údajov pre faktory metodiky BOSSING a metodiky NAQ

\begin{tabular}{lccc}
\hline & $\begin{array}{c}\text { Bossing zameraný } \\
\text { na prácu }\end{array}$ & $\begin{array}{c}\text { Bossing } \\
\text { zameraný } \\
\text { na psychiku }\end{array}$ & Mobbing \\
\hline Skewness & 1.516 & 3.312 & 0.266 \\
Kurtosis & 1.976 & 2.680 & 2.032 \\
\hline
\end{tabular}

Z hl'adiska validácie metodiky BOSSING boli analyzované korelačné koeficienty medzi extrahovanými faktormi Bossing zameraný na prácu, Bossing zameraný na psychiku a celkovým skóre Mobbingu (metodika NAQ) (tabul'ka 2). Získané výsledky potvrdili existenciu štatisticky významného, ale slabého vzt’ahu medzi faktorom Bossing zameraný na prácu a celkovým skóre metodiky NAQ. Zároveň vzt’ah medzi Bossingom zameraným na psychiku a Mobbingom nebol identifikovaný. Aj napriek uvedeným charakteristikám vzt’ahu medzi použitými metodikami, je možné identifikovat' tendenciu, že čím vyššie je skóre respondentov v metodike NAQ, tým vyššie sú ich výsledky v metodike BOSSING.

Toto zistenie dokazuje, že čím negatívnejšie respondenti hodnotili fenomén šikanovania vo všeobecnosti, tým negatívnejšie hodnotili prejavy bossingu z hl'adiska práce aj psychiky (tabul'ka 2). Hodnoty zistených korelačných koeficientov svedčia v prospech potvrdenia 
validity metodiky BOSSING, zároveň však poukazujú na skutočnost', že uvedenými metodikami nie sú zist'ované totožné charakteristiky.

Tabul'ka 2. Vztah medzi faktormi Bossing zameraný na prácu, Bossing zameraný na psychiku a Mobbingom

\begin{tabular}{lcc}
\hline & $\begin{array}{c}\text { Bossing zameraný } \\
\text { na prácu }\end{array}$ & $\begin{array}{c}\text { Bossing zameraný } \\
\text { na psychiku }\end{array}$ \\
\hline Mobbing & 0.267 & 0.117 \\
$\mathrm{p}$ & 0.000 & 0.000 \\
\hline
\end{tabular}

Analýza vzt'ahov medzi faktormi bossingu, ukazovatel'om mobbingu a osobnostnými črtami potvrdila existenciu viacerých štatisticky významných záporných korelácií (tabul'ka 3). Štatisticky významné vzt’ahy neboli zistené len medzi osobnostnou črtou neurotizmus a skúmanými faktormi bossingu. Získané výsledky svedčia o skutočnosti, že čím sa zamestnanci posúdili ako viac extravertovaní, otvorení, prívetiví s svedomití, tým vyjadrili nižšiu mieru frekvencie výskytu prejavov mobbingu a tým menej citlivo vnímajú výskyt prejavov bossingu na pracovisku.

Tabul'ka 3. Vzt'ahy medzi posudzovaním prejavov bossingu, mobbingu a osobnostnými črtami zamestnancov

\begin{tabular}{lccc}
\hline & $\begin{array}{c}\text { Bossing zameraný } \\
\text { na prácu }\end{array}$ & $\begin{array}{c}\text { Bossing zameraný } \\
\text { na psychiku }\end{array}$ & Mobbing \\
\hline Neurotizmus & -0.016 & -0.009 & -0.102 \\
$\mathrm{p}$ & 0.690 & 0.825 & 0.010 \\
Extraverzia & -0.246 & -0.250 & -0.323 \\
$\mathrm{p}$ & 0.000 & 0.000 & 0.000 \\
Otvorenost' & -0.146 & -0.147 & -0.199 \\
$\mathrm{p}$ & 0.000 & 0.000 & 0.000 \\
Prívetivost' & -0.266 & -0.272 & -0.388 \\
$\mathrm{p}$ & 0.000 & 0.000 & 0.000 \\
Svedomitost' & -0.193 & -0.194 & -0.294 \\
$\mathrm{p}$ & 0.000 & 0.000 & 0.000 \\
\hline
\end{tabular}

Prejavy bossingu menej citlivo vnímajú zamestnanci, ktorí sú veselí, nadšení, priatel'skí, spoločenskí, dobrosrdeční, ústretoví, nápomocní, svedomití, spol’ahliví, sebadisciplinovaní, nekonvenční, abstraktne mysliaci, skúmajúci. Sú to zamestnanci, ktorí sú pozitívne orientovaní. 


\section{Diskusia}

V kontexte výskumov nežiaducich foriem správania nadriadených $\mathrm{k}$ podriadeným je možné diskutovat' o viacerých pojmoch, ako je šikanovanie smerom nadol (Oberhofer, 2018), vertikálny mobbing (Arnejčič, 2016; Zikic et al., 2013), toxický bossing (Hamilton et al., 2017), boss syndróm (Emelander, 2011). Oberhofer (2018) uvádza, že bossing je špecifický pojem používaný predovšetkým v niektorých európskych, nemecky hovoriacich regiónoch. Arnejčič (2016) kategorizuje bossing v rámci tzv. vertikálneho mobbingu, ku ktorému dochádza, ked’ jednotlivec ohovára podriadeného zamestnanca. Zikic et al. (2013) súhlasia s touto teóriou a tvrdia, že vertikálny mobbing alebo bossing nastáva, ked' je podriadený mobovaný supervízorom. Hamilton et al. (2017) predstavujú pojem toxický bossing, ktorý dešifrujú ako formy zneužívajúceho správania zamerané na podriadených na pracovisku. V tomto kontexte Emelander (2011) používa všeobecnejší výraz „,boss syndróm“, ak nadriadení nevedia, ako zaobchádzat's najdôležitejším zdrojom spoločnosti, t.j. s l'ud'mi.

Väčšina výskumov orientovaných na osobnostné kontexty bossingu je zameraná na skúmanie osobnostných čŕt nadriadeného, ako subjektu nežiaducich foriem správania (Camps et al., 2016; Wilson, Nagy, 2017). Menej výskumov je zameraných na analýzu osobnostných čŕt podriadených v kontexte ich vnímania nežiaducich foriem správania nadriadených (Brees, et al., 2016). Uvedení autori skúmali súvislosti medzi osobnostnými črtami zamestnancov a ich vnímaním zneužívajúceho, urážlivého správania nadriadeného. Zistili, že podriadení, ktorí skórovali vyššie v negatívnej afektivite, hnevu, nepriatel'skosti vnímali citlivejšie uvedené prejavy nadriadených. Uvedené zistenia korešpondujú s výsledkami prezentovaného výskumného projektu.

Prejavy bossingu a mobbingu sú významným faktorom pri predikcii a interpretácii správania l’udí v rôznych kontextoch práce. Jedným zo spoločných menovatel’ov týchto prejavov je znižovanie produktivity práce, absentérstvo, fluktuácia, znižovanie angažovanosti a výrazné ekonomické dôsledky (Hirigoyen, 2000 a i.). Zároveň je nevyhnutné poukázat' na pôsobenie bossingu a mobbingu na psychiku každého zamestnanca s dôsledkami aj na fyzické zdravie l'udí. Pri posudzovaní prejavov bossingu v správaní nadriadených a prijímaní záverov je nevyhnutné akceptovat' komplexný prístup, ktorý zahŕňa kultúrne vzorce správania, situačné podmienky výskytu tohto správania, ako aj osobnostné črty zamestnancov. Potrebné je upozornit' na subjektívnost' vnímania týchto prejavov správania.

Uvedený prístup súvisí s holistickým konceptom vymedzenia tejto problematiky. Z hl'adiska tohto konceptu je nutné chápat' ekonomické, sociálno-kultúrne a osobnostné atribúty ako jeden celok, ktorý sa odlišuje od súhrnu výsledkov štúdia jednotlivých prvkov bossingu. Tento koncept zároveň prispieva k vymedzeniu hranice medzi bossingom a normálnym, aj ked' tvrdým správaním nadriadeného. Ked’že v každej firme sú zamestnanci zvyknutí na rôzne štandardy, niekedy je vel'mi t'ažké rozpoznat', čo ešte je a čo už nie je prípustné a spadá do prejavov bossingu (Bednař, 2016).

V kontexte tohto prístupu bola v prezentovanom príspevku pozornost' sústredená na problematiku súvislostí medzi osobnostnými črtami zamestnancov a posudzovaním prejavov bossingu. Rovnaký koncept je nevyhnutné akceptovat' aj pri skúmaní problematiky mobbingu. Výsledky výskumu potvrdili zmysluplnost' uvažovania o súvislostiach medzi osobnostnými 
črtami zamestnancov a posudzovaním prejavov bossingu, resp. mobbingu. Analýza súvislostí medzi faktormi bossingu a osobnostnými črtami zist'ovanými z hl’adiska konceptu Big Five potvrdila, okrem črty neurotizmus, existenciu štatisticky významných korelácií. Č́m sú zamestnanci viac extravertovaní, otvorení, prívetiví a svedomití, tým menej citlivo vnímajú výskyt prejavov bossingu na pracovisku.

V tejto etape výskumu je možné za limitujúci faktor považovat' pôsobenie situačných faktorov a kultúrnych súvislostí. Zároveň na základe vysokých hodnôt Cronbachovej alpha je možné zvážit' počet jednotlivých položiek sýtiacich faktory.

\section{Literatúra}

Arnejčič, B. (2016). Mobbing in Company: Levels and Typology. Organizacija, 49(4), 240250. http://doi.org/10.1515/orga-2016-0021

Bednař, Z. (2016). Jak vyjít se svým šéfem. Praha: Grada Publishing.

Bennett, R. J. (2000). Development of a measure of workplace deviance. Journal of Applied Psychology, 85(3), 349-360. http://doi.org/10.1037/0021-9010.85.3.349

Birknerová, Z., \& Frankovský, M. (2017). Nežiaduce formy správania manažérov. Prešov: Bookman, s.r.o.

Birknerová, Z., Juhás, J., \& Litavcová, E. (2010). Súvislosti medzi sociálnou inteligenciou, strachom a mobbingom v prostredí školy. In Sociální procesy a osobnost 2009. Brno: PsÚ AV ČR, v.v.i.

Borská, I. (2005). Mobbing a bossing - jak se bránit? Personální a sociálně právní kartotéka, $11,8-10$.

Brees, J., Martinko, M., \& Harvey, P. (2016), Abusive supervision: subordinate personality or supervisor behavior? Journal of Managerial Psychology, 31(2), 405-419. http://doi.org/10.1108/JMP-04-2014-0129

Camps, J., Stouten, J., \& Euwema, M. (2016). The relation between supervisors' Big Five personality traits and employees' experiences of abusive supervision. Frontiers in Psychology, 7, Article ID 112. http://doi.org/10.3389/fpsyg.2016.00112

Einarsen, S., Raknes, B. I., Matthiesen, S. B., \& Hellesøy, O. H. (1994). Mobbing og harde personkonflikter: Helsefarlig samspill på arbeidsplassen. Bergen, Norway: Sigma Forlag, $256 \mathrm{p}$.

Einarsen, S. et al. (2011). The Concept of Bullying and Harassment at Work: The European Tradition. In Bullying and Harassment in the Workplace. USA: Taylor \& Francis Group. http://doi.org/10.1201/EBK1439804896-3

Emelander, S. (2011). Managing, Leading, and Bossing. Defense AT\&L, July-August 2011, $76-78$. 
Frankovský, M., Birknerová, Z., \& Droppa, M. (2019). Methodological Study of the Selected Attributes of the Bossing Questionnaire. In Journal of management and business research and practice, 1,11 .

Görgülü, N. et al. (2014). The effects of mobbing (bullying) on health employes. In Procedia - Social and Behavioral Sciences, 152, 503-509.

http://doi.org/10.1016/j.sbspro.2014.09.196

Hafidz, S. M. (2012). Individual Differences as Antecedents of Counterproductive Work Behaviour. Social Science, 8(3), 220-226. http://doi.org/10.5539/ass.v8n13p220

Hamilton, D. I., Ogbuigwe, T., \& Gabriel, J. M. O. (2017). Narcissistic Bossing and Deviant Workplace Behavior among Subordinates in the Nigerian Civil Service. International Journal of Arts and Humanities, 1(9), 735-762.

Hirigoyen, M. F. (2000). Stalking the soul: Emotional abuse and the erosion of identity. New York: Helen Marx Books.

Howladar, M. H. R. et al. (2018). Deviant WorkplaceBehavior and Job Performance: The moderating Effect of Transformational Leadership. Iranian Journal of Management Studies, 11(1), 147-183.

Huberová, B. (1995). Psychický teror na pracovišti: mobbing. Martin: Neografie.

Janovská, A. (2011). Subjektívna pohoda učitel’ov a jej vzt’ah k osobnostným a interpersonálnym činitel’om. Dizertačná práca. Košice: Univerzita Pavla Jozefa Šafárika v Košiciach, Filozofická fakulta, Katedra psychológie.

Leymann, H. (1990). Mobbing and Psychological Terror at Workplaces. In Violence and Victims, 5(2), 119-126. http://doi.org/10.1891/0886-6708.5.2.119

Oberhofer, P. (2018). Bossing und Staffing: Mobbing zwischen Chef und Mitarbeitern. Konfliktmanagement [online]. Dostupné z: https://www.jobadu.de/pdfs/01502.pdf

Olšovská, A. (2013). Mobbing a bossing na pracovisku. Správa z VÚ č. 2162. Bratislava: Inštitút pre výskum práce a rodiny.

Robinson, S. L., \& Bennett, R. J. (1995). A typology of deviant workplace behaviors: A multidimensional scaling study. Academy of Management Journal, 38(2), 555-572. http://doi.org/10.2307/256693

Skopalová, J. (2000). Vybrané kapitoly ze sociálních deviací. Olomouc: Vydavatelství Univerzity Palackého.

Spector, P. E., \& Fox, S. (2002). An emotion-centered model of voluntary work behavior: Some parallels between counterproductive work behavior and organizational citizenship behavior. Human Resource Management Review, 12(2), 269-292. http://doi.org/10.1016/S1053-4822(02)00049-9

Wilson, C. J., \& Nagy, M. S. (2017). The effects of personality on workplace bullying. The Psychologist-Manager Journal, 20(3), 123-147. http://doi.org/10.1037/mgr0000054

Zapf, D., \& Leymann, H. (1996). Mobbing and Victimization at Work: A Special Issue of the 
European Journal of Work and Organizational Psychology. UK: Psychology Press.

Zikic, S., Paunkovic, J., \& Cvetkovic, A. (2013). The Organizational Structure Affects the Occurrence of Mobbing. In Proceedings: Advances in Fiscal, Political and Law Science, The 2nd International Conference on Economics, Political and Law Science (EPLS '13) (pp. 232-236). Romania: Brasov.

\section{Korespondující autor}

doc. PhDr. Miroslav Frankovský, CSc.

Prešovská univerzita, Fakulta manažmentu, Katedra manažérskej psychológie

Konštantínova 16, 08001 Prešov, Slovenská republika

miroslav.frankovsky@unipo.sk

Grantová podpora: 003PU-4/2017 - KEGA: Zvládanie náročných situácií - inovácia predmetu a príprava vysokoškolskej učebnice 


\title{
Smart Factory. What Employees Will the Company Need in the Future?
}

\section{Smart Factory. Jaké zaměstnance bude firma potřebovat $v$ budoucnu?}

Aleš Gregarl, Ivana Pejřovál, Jana Matoškovál

${ }^{1}$ Univerzita Tomáše Bati ve Zlíně, Zlín, Česká republika

\begin{abstract}
Objective. The purpose of the paper is to provide information about a research project aimed at supporting the implementation of the Smart Factory concept (management system with support of digitization and robotization) in the production plant ALPS Electric CZ, Sebranice, regarding changes in working roles, working conditions, development of employees, changes in conditions for in-company communication and overall changes in corporate culture in ALPS Electric CZ, Sebranice. For research purposes, the research problem was formulated and six research questions were set.
\end{abstract}

Method. About 400 employees work at ALPS, of which about 350 are in production. The research target groups are six work groups that are directly related to production - process engineers, foremen, purchasing, planning and production preparation, logistics (focusing on material supply), manufacturing operators and middle management. Methods for data collection: document analysis, interviews, questionnaire, and findings from selected companies. With regard to the realization of research in one company, we will use descriptive statistics for the analysis and interpretation of data.

Conclusion. The findings of the research will help ALPS management to identify and eliminate potential barriers concerning employees when implementing the Smart Factory concept. We will propose measures to support the implementation of the Smart Factory concept in the ALPS specifically focused on work positions and system measures supporting the "smart" change of the ALPS Electric corporate culture.

Limitations. The conclusions of the research are based on one medium-sized production plant, and are not generally valid. The Smart Factory concept focuses only on the range of jobs that are directly related to production; it does not take into account the need to assess the impact of digitizing jobs indirectly related to production (ECO, HR, MKT).

Keywords. Smart Factory; management system; digitization, robotization; work position; qualifications, working conditions; organizational culture

https://doi.org/10.5817/CZ.MUNI.P210-9488-2019-11 


\begin{abstract}
Abstrakt
Cíl. Účelem príspěvku je podat informaci o výzkumném projektu, jehož cílem je podpora implementace konceptu Smart Factory (systém řizeni s podporou digitalizace a robotizace) $v$ prostředí výrobního závodu ALPS Electric CZ, Sebranice, s ohledem na změny pracovních rolí, pracovních podminek, kvalifikačních požadavků, kariérových modelů rozvoje pracovniků, změny podmínek pro vnitrofiremni komunikaci a celkové změny firemni kultury v ALPS Electric CZ, Sebranice. Pro účely výzkumu byl formulován výzkumný problém a stanoveno šest výzkumných otázek.
\end{abstract}

Metoda. V ALPS pracuje cca 400 pracovníků, z toho cca 350 operátorů ve výrobě. Cílovou skupinou výzkumu je sedm okruhů pracovních mist, která mají př́mý vztah k výrobè-procesní inženýri, předáci a mistři, nákup, plánováni a př́prava výroby, logistika (se zaměřením na zásobování výroby materiálem), operátoři ve výrobě a střední management. Metody pro sběr dat: analýza dokumentů, rozhovory, dotaznik, poznatky z vybraných firem. S ohledem na realizaci výzkumu v podmínkách jedné firmy použijeme pro analýzu a interpretaci dat popisnou statistiku.

Závěry. Závěry výzkumu pomohou vedeni ALPS identifikovat a eliminovat možné bariéry na straně pracovníků př implementaci konceptu Smart Factory. Navrhneme opatření na podporu implementace konceptu Smart Factory v prostředi ALPS specificky zaměrené na jednotlivé okruhy pracovnich pozic a systémová opatrení podporujicí „smart“ změnu firemní kultury ALPS Electric CZ.

Limity. Závěry výzkumu vycházejí z podmínek jednoho výrobního závodu střední velikosti, nemaji obecnou platnost. Koncept Smart Factory je zaměren jen na okruh pracovních mist, které maji př́mý vztah $k$ výrobě, není brána do úvahy potřeba vyhodnocovat vliv digitalizace pracovnich mist neprimo souvisejicich s výrobou (EKO, HR, MKT).

Klíčová slova. Smart Factory; systém řízení; digitalizace, robotizace; pracovní pozice; kvalifikace, pracovní podmínky; organizační kultura

\title{
Úvod
}

Chytrá továrna (smart factory, SF) je systém řízení s podporou robotizace, digitalizace, big data, Industrial Internet of Things (IIoT) a umělé inteligence (Artificial Intelligence, AI). Koncept SF představuje skok vpřed od tradiční automatizace k plně připojenému a flexibilnímu systému, který může používat nepřetržitý tok dat z připojených operací a výrobních systémů, aby se učil a přizpůsobil se novým požadavkům. I v inteligentní továrně se ale předpokládá, že lidé stále budou klíčem k operacím a procesům. Dojde však k velkým změnám v charakteristice požadovaných operací a tím ke změně rolí na podporu nových procesů, ke změně požadavků na znalosti, dovednosti a schopnosti pracovníků. Část rolí bude postupně zanikat, protože je budou nahrazovat kolaborativní roboti a automatizace procesů. Další role budou doplněny o nové funkce např́klad o virtuální realitu, vizualizaci dat a umělou inteligenci. Objeví se také role nové, zatím neznámé (Balga, 2018; Frey \& Osborne, 2013). 
Nové technologie odstraní fyzicky namáhavé a rutinní práce, práce, které jsou životu nebezpečné, či jejichž dlouhodobý výkon ohrožuje zdraví a způsobuje nemoci z povolání. Přinesou také možnost kvalitativního obohacení práce, jejího výkonu $\mathrm{v}$ zajímavějším pracovním prostředí, větší autonomii a více příležitostí pro profesní rozvoj a prostor pro inovativní myšlení. Na druhé straně, nové výrobní postupy kladou jiné požadavky na pracovní způsobilost pracovníků (Kolektiv NVF-NOZV, 2017; Ras et al., 2017; Chmelař et al., 2015).

Proces digitalizace ekonomiky neznamená jen ohrožení určitých profesí a pracovních míst, popř. jejich významnou transformaci, ale vytváří také předpoklady pro vznik profesí a pracovních míst zcela nových. Největší potenciál vzniku pracovních míst je spojován $\mathrm{s}$ rozvojem ICT a zaváděním nových technologií, s budováním platformy Průmyslu 4.0 a obecně Společnosti 4.0. Vzhledem k tomu, že firma ALPS je napojena na automobilový průmysl, musí věnovat velkou pozornost postupu digitalizace, robotizace a rozvoji ICT. Charakteristiky SF v automobilové výrobě směrují k trvalému zvyšování výkonosti, orientaci na zákazníky, individualizaci výroby, zlepšování pracovních podmínek ve výrobním procesu, snižování pracovní zátěže uplatněním ergonomických opatření a k zodpovědnému vztahu k životnímu prostředí (Kohout \& Palíšková, 2017; Yuan et al., 2017).

Pravděpodobně vzroste počet pracovních míst vyžadujících vyšší úroveň vzdělání. Požadavek na úzkou specializaci $v$ jednom oboru ustoupí a budou vyžadovány současně hluboké odborné znalosti v jednom oboru a široké znalosti napříč mnoha disciplínami. Budoucí zaměstnanec by měl tedy disponovat komplexnějšími znalostmi a dovednostmi, aby byl schopen uvažovat a rozhodovat se v širších souvislostech (Jackson et al., 2003; Davenport \& Prusak, 1998).

Zaměstnanci budou muset rozumět procesům, jejich vzájemné provázanosti a budou potřebovat znalosti a dovednosti spojené se sběrem a použitím dat (Ras et al., 2017). Proto by součástí základního vzdělání každého jedince měla být digitální gramotnost, zejména schopnost umět informační a komunikační technologie používat $\mathrm{k}$ efektivnímu řešení problémů a schopnost efektivně pracovat s informacemi. Kromě hard-skills (odborných, technických a jazykových dovedností) bude dále narůstat význam soft-skills (Kohout \& Palíšková, 2017; Horváthová et al., 2016; Frey \& Osborne, 2013).

Důležitá bude schopnost komunikace, koncepčního a kritického myšlení, sociální inteligence, kreativita, schopnost vedení týmu a spolupráce, odolnost vůči stresu, schopnost rychle reagovat a samostatně se rozhodovat a řešit problémy, schopnost sdílet informace, schopnost tolerance a sebeřízení (Kolektiv NVF-NOZV, 2017; Amidi et al., 2017).

Zároveň budou kladeny větší nároky na flexibilitu pracovníků. Bude vyžadována rychlá reakce $\mathrm{v}$ odpovědi na změny potřeb různých zákazníků i profesní flexibilita ze strany pracovníků, jejich neustálé vzdělávání a výchova příslušných specialistů, které si každý podnik bude doplňovat vzdělání podle svých potřeb. S tím souvisí narůstající význam celoživotního vzdělávání, např́iklad schopnost průběžně si osvojovat nové trendy v technologiích a neustále rozvíjet své IT znalosti a dovednosti a potřebnost proaktivního př́stupu a samostatnosti zaměstnanců. Zaměstnanci budou muset akceptovat změnu jako přirozenou součást života (Kohout \& Palíšková, 2017; Ras et al., 2017; Yuan et al., 2017). 
V souvislosti s postupující ekonomickou globalizací a internacionalizací lze očekávat, že zaměstnanci budou stále častěji pracovat v prostředí multikulturních týmů. To bude vyžadovat interkulturní senzitivitu, tj. disponovat určitými interkulturními kompetencemi, do kterých se promítají osobnostní předpoklady jako sebereflexe, empatie, kulturní citlivost, zvídavost, zkušenost, tolerování odlišnosti a sebedůvěra či snížená míra úzkostlivosti. Pracovníci v multikulturním týmu by měli umět respektovat druhé, mít znalosti o jiných kulturách a neříkat si, že vše umí nejlépe a netrvat na tom, že věci se musí dělat bezpodmínečně jen jejich osvědčeným způsobem. Je zapotřebí, aby se lidé naučili respektovat jiný způsob myšlení kolegů, jejich odlišný styl práce, př́istup k lidem, konfliktům a jejich odlišné nastavení priorit v pracovním i osobním životě (Šlapalová Čempelová, 2013; Yuan et al., 2017; Frey \& Osborne, 2013).

Výzkumný problém vyplývající z teoretického úvodu lze formulovat následovně:

Jaký vliv má digitalizace řízení výroby a implementace konceptu SF na zaměstnance? Jak podporovat implementaci konceptu SF s ohledem na úspěšné zvládnutí změny pracovních rolí, změny pracovních podmínek, změny kvalifikačních požadavků, změny karierových modelů rozvoje pracovníků, změny motivačních faktorů, změny podmínek pro vnitrofiremní komunikaci a celkové změny podnikové kultury v ALPS?

Výzkumné otázky vyplývající z teoretického úvodu lze stanovit následovně.

VO1: Které okruhy pracovních pozic jsou relevantní pro systém ř́zení SF v prostředí ALPS?

VO2: Které specifické povinnosti, potřeby a požadavky pro jednotlivé okruhy pracovních pozic jsou relevantních pro systém řízení SF v ALPS?

VO3: Které Key Performace Indicators (KPI) pro jednotlivé okruhy pracovních pozic jsou relevantní pro systém řízení SF v ALPS?

VO4: Které překážky v jednotlivých okruzích pracovních pozic jsou relevantní pro implementaci systému ř́izení SF? Jaká jsou opatření pro jejich překonání?

VO5: Jaký je vliv systému řízení SF na stávající firemní kulturu ALPS (hodnoty, normy chování, artefakty)?

VO6: Jaká jsou opatření pro formování „smart“ firemní kultury pro ALPS jako podpora systému řízení SF v prostředí ALPS?

\section{Metody}

Pro zodpovězení VO1 bude provedena analýza současného stavu, tj. přehled pracovních míst, popisy pracovních míst, roztř́iění pracovních míst podle relevance ve vztahu $\mathrm{k}$ implementaci systému řízení SF v podmínkách ALPS. Pro třídění pracovních míst bude použita tříbodová škála: „ano, možná, ne“, s ohledem na to, do jaké míry budou jednotlivá pracovní místa ovlivněna implementací $\mathrm{SF}$, přičemž ano $=2$ body, možná $=1$ body, ne $=0$ bod. Toto hodnocení provedou individuálně členové pracovního týmu (10 osob).

Pro zodpovězení VO2 bude využita Národní soustavu povolání, a následně budou vytipovány, které specifické povinnosti, potřeby, požadavky, odborné a obecné znalosti a dovednosti u zaměstnanců může přechod ke SF ovlivňovat. 
Pro zodpovězení VO3 bude provedena analýza současného stavu KPI pro jednotlivé okruhy pracovních pozic relevantních pro systém řízení SF v ALPS a budou navržena opatření pro jejich úpravu.

Pro zodpovězení VO4 bude provedena analýza současného stavu existence překážek v jednotlivých okruzích pracovních pozic relevantních pro implementaci systému řízení SF a budou navržena opatření pro jejich překonání.

Pro zodpovězení VO5 a VO6 bude provedena analýza vlivu systému řízení SF na stávající firemní kulturu ALPS (hodnoty, normy chování, artefakty) a budou navržena opatření pro formování „smart“ firemní kultury pro ALPS jako podpory systému rrízení SF v prostředí ALPS.

Pro zodpovězení otázek VO1 až VO6 budou využity také poznatky z vybraného okruhu firem, které se tématem digitalizace řízení výroby a konceptem SF zabývají (publikace, konference, semináře, workshopy).

Pro zodpovězení otázek VO3 až VO6 budou využity řízené rozhovory, včetně formuláře pro záznam odpovědí. Otázky pro řízené rozhovory budou stanoveny na základě současného stavu dané problematiky $\mathrm{v}$ ALPS a na základě poznatků $\mathrm{z}$ literatury $\mathrm{k}$ danému tématu. Předpokládáme, že rozhovory s pracovníky ALPS proběhnou v řrijnu/listopadu 2019, cca 20 rozhovorů, délka 30-45 minut.

Pro zodpovězení otázek VO5 a VO6 bude využita metoda dotazníku. Dotazník bude vybrán z okruhu dotazníků používaných při výzkumu firemní kultury (Bock et al., 2005; Yang, 2007). Dotazníkové šetření proběhne na jaře 2020, cca. 100 respondentů.

Firma ALPS má cca 400 pracovníků, z toho cca 350 na pozicích operátorů ve výrobě a na montáži. Respondenty budou pracovníci z těchto sedmi okruhů pracovních míst: procesní inženýři, předáci a mistři, nákup, plánování a př́prava výroby, logistika (se zaměřením na zásobování výroby materiálem), operátoři ve výrobě a stř̌ední management. Těchto sedm okruhů pracovních míst bylo stanoveno po konzultaci s personálním oddělením firmy ALPS. Kritériem pro tento výběr byl přímý vztah těchto pracovních pozic $\mathrm{k}$ výrobnímu úseku.

$\mathrm{S}$ ohledem na realizaci výzkumu v podmínkách jedné firmy (ALPS) bude pro analýzu a interpretaci dat použita popisná statistika.

\section{Závěr}

Výsledkem řešení projektu budou opatření na podporu implementace konceptu SF s ohledem na úspěšné zvládnutí změny pracovních rolí, změny pracovních podmínek, změny kvalifikačních požadavků, změny karierových modelů rozvoje pracovníků, změny motivačních faktorů, změny podmínek pro vnitrofiremní komunikaci a celkové změny podnikové kultury ve firmě ALPS. K formulaci opatření budou využity poznatky z odborných publikací, informace zjištěné pomocí rozhovorů ve vybraných firmách (best practices), výsledky výzkumu realizovaného ve firmě ALPS Electric CZ Sebranice.

V podmínkách firmy ALPS byly definovány tyto oblasti výzkumu:

- stanovení okruhů pracovních pozic relevantních pro implementaci konceptu SF v prostředí ALPS, 
- stanovení specifických povinností, potřeb a požadavků pro jednotlivé okruhy pracovních pozic relevantních pro SF v ALPS,

- stanovení KPI pro jednotlivé okruhy pracovních pozic relevantních pro SF v ALPS,

- identifikace potenciálních implementačních překážek v jednotlivých okruzích pracovních pozic relevantních pro SF a stanovení možných opatření k jejich překonání,

- identifikace vlivu SF na stávající firemní kulturu ALPS (hodnoty, normy chování, artefakty),

- stanovení opatření pro formování „smart“ firemní kultury pro ALPS jako podpora implementace SF v prostředí ALPS.

V současnosti je velmi obtížné přesně určit, jak se budou jednotlivé pracovní pozice měnit, popř. zanikat či vznikat zcela nové, jaké konkrétní znalosti a dovednosti budou s nimi spojeny, lze identifikovat jen určité obecné trendy. To, jaké dopady bude mít zavádění technologií na zaměstnance, zda zaměstnanci budou technologie vnímat jako užitečné nebo ohrožující, bude mimo jiné ovlivněno firemní kulturou dané organizace. S jistotou však lze říci, že získané znalosti a dovednosti budou zastarávat mnohem rychleji, než je tomu nyní. $Z$ tohoto důvodu vzroste význam celoživotního vzdělávání, včetně podnikových forem vzdělávání (Kohout \& Palíšková, 2017).

Je zřejmé, že kromě posunu ve formách zaměstnávání budou v důsledku digitalizace a robotizace probíhat na pracovištích minimálně dvě další zásadní změny. Zaprvé, bude ve zvýšené míře docházet k zániku a vzniku pracovních míst a profesí, popřr. k jejich transformaci. Zadruhé, významně vzrostou nároky na kvalifikaci pracovníků resp. její změnu (na všech úrovních), proto oblast personálního řízení ve firmách musí projít změnou od tradiční orientace na administrativu spojenou s pracovní sílou, k podpoře rozvoje a angažovanosti pracovníků. Poroste význam podnikového vzdělávání, a to i u starších zaměstnanců či u operátorů. I operátoři budou muset rozumět datům a umět si pro jejich práci potřebná data zobrazit, analyzovat a interpretovat je. Bude zapotřebí pracovníky průběžně přšškolovat a rekvalifikovat na nové technologie.

$\mathrm{V}$ souvislosti s různými generacemi zaměstnanců (generace $\mathrm{X}, \mathrm{Y}$ a Z ), které se ve firmě potkávají, jejich odlišnostem v př́stupu k práci, IT schopnostem a dovednostem, je potřebné přijmout koncept Age managementu, který pracuje s přednostmi všech věkových kategorií zaměstnanců. Důležité bude podporovat angažovanost zaměstnanců a jejich zapojení do chodu firmy. Ke klíčovým motivátorům pro pracovníky bude patřit, osobní růst (př́iležitost pro jedince plně realizovat svůj potenciál), autonomie, uspokojení z práce vysoké kvality, významné pro firmu. Dále, otevřené vztahy na pracovišti, kvalitní komunikace, soulad s posláním organizace, sdílené firemní hodnoty, silná firemní kultura.

Výzkum řeší digitalizaci a robotizaci jako podporu pro ř́zení výroby, není řešena transformace řízení dalších úseků (EKO, HR, MKT). Koncept SF musí řešit transformaci celé firmy v souvislosti s digitalizací a robotizací. Tento požadavek je zadáním pro další pokračování výzkumu v oblasti SF v ALPS. 


\section{Literatura}

Amidi, A., M., Jabar, Y. Y., \& Abdullah, R. (2017). Appropriation of social media for fostering effective tacit knowledge sharing: developing conceptual model. Journal of Physics: Conference Series, 892(1), 1-2012. http://doi.org/10.1088/1742$\underline{6596 / 892 / 1 / 012012}$

Balga, B. (2018). SMART factory - inteligentní továrna - IPA Czech. Dostupné z: https://www.ipaczech.cz/cz/tisk-a-media/aktuality/smart-factory-inteligentni-tovarna

Bock, G., Zmud, R. W., Kim, Y., \& Lee J. (2005). Behavioral intention formation in knowledge sharing: Examining the roles of extrinsic motivators, social-psychological forces, and organizational climate. MIS quarterly, 29(1), 87-111. https://doi.org/10.2307/25148669

Davenport, T. H., \& Prusak, L. (1998). Working knowledge: how organizations manage what they know. Boston, Mass: Harvard Business School Press.

Horváthová, P., Bláha, J. \& Čopíková, A. (2016). Řizení lidských zdrojů: Nové trendy. B.m.: Management Press.

Frey, C. B. \& Osborne, M. A. (2013). The Future of Employment: How susceptible are jobs to computerisation? Oxford University, September 17, 2013. (cit. 2019-04-28). Dostupné z: https://grid.cs.gsu.edu/ nkeller4/The\%20Future\%20of\%20Employment.pdf

Chmelař, A. et al. (2015). Dopady digitalizace na trh práce v $\check{C} R$ a EU. OSTEU Discussion paper, 12. Dostupné z: https://www.vlada.cz/assets/evropskezalezitosti/analyzyEU/Dopady-digitalizace-na-trh-prace-CR-a-EU.pdf.

Jackson, S. E., Hitt, M. A. \& Denisi, A. S. ed. (2003). Managing knowledge for sustained competitive advantage: designing strategies for effective human resource management. San Francisco: Jossey-Bass. The organizational frontiers series.

Kohout, P. \& Palíšková, M. (2017). Dopady digitalizace na zaměstnanost a sociální zabezpečení zaměstnanců [online]. červenec 2017. Dostupné z: http://ipodpora.odbory.info/soubory/dms/wysiwyg_uploads/bba5a5c7366cdaf3/uploads/St udie Dopady digitalizace.docx

Kolektiv NVF-NOZV. (2017). Dopady Průmyslu 4.0 na trh práce v $\check{C} R$ [online]. 2017. B.m.: Národní vzdělávací fond. Dostupné z:

http://www.nvf.cz/cms/assets/docs/88ffb3e9f7da58fefd9741bca08796a3/794-0/dopadyprumyslu4.0-na-trh-prace-v-cr.pdf

Ras, E., Wild, F., Stahl, Ch. et al. (2017). Bridging the Skills Gap of Workers in Industry 4.0 by Human Performance Augmentation Tools: Challenges and Roadmap. In: The 10th International Conference: Proceedings of the 10th International Conference on Pervasive Technologies Related to Assistive Environments - PETRA '17 [online] (pp. 428-432). Island of Rhodes, Greece: ACM Press. http://doi.org/10.1145/3056540.3076192

Šlapalová Čepelová, Z. (2013). Cesta k multikulturnímu týmu [online]. Dostupné z: http://modernirizeni.ihned.cz/c1-60518520-cesta-k-multikulturnimu-tymu 
Yang, J. (2007). Knowledge sharing: Investigating appropriate leadership roles and collaborative culture. Tourism Management, 28(2), 530-543.

http://doi.org/10.1016/j.tourman.2006.08.006

Yuan, Y. H., Tsai, S. B., Dai, C.Y., et al. (2017). An empirical research on relationships between subjective judgement, technology acceptance tendency and knowledge transfer. PLoS ONE, 12(9). http://doi.org./10.1371/journal.pone.0183994

\section{Korespondující autor}

doc. PhDr. Ing. Aleš Gregar, CSc.

Univerzita Tomáše Bati ve Zlíně, Fakulta managementu a ekonomiky

Mostní 5139, 76001 Zlín, Česká republika

gregar@utb.cz

Grantová podpora: Výzkumný projekt je podporován grantem MPO ČR, OPPIK - program APLIKACE - Výzva č. IV, termín řešení 3/2019 - 8/2020. 


\section{The Causes and Context of Job Insecurity in Slovakia}

\section{Príčiny a kontexty pracovnej neistoty na Slovensku}

Michal Kentošl

${ }^{1}$ Spoločenskovedný ústav, CSPV SAV, Slovensko

\section{Abstract}

The presented study deals with the research of job insecurity. Job insecurity is in this context defined as perceived threat that of job lose.

Objective. The aim of the study is to analyze the current level of job insecurity in our conditions in the context of contradictory findings on the level of job insecurity in Slovakia. At the same time, the causes of job insecurity were investigated.

Method. Following the findings on the incidence, intensity and context of job insecurity, research of the working population was conducted using an online panel on a sample of 1010 respondents, including 508 women and 502 men.

Results. The results of the study indicate that the level of job insecurity is mainly due to the method of its measurement. Factors of job insecurity, along with traditional socio-demographic predictors at its level, were influenced by factors of organizational changes, competence, and individual's influence on work.

Limits. The limit of the study as well as the results is the method of data collection only by Internet users.

Keywords. job insecurity; working conditions; sociodemographic predictors

https://doi.org/10.5817/CZ.MUNI.P210-9488-2019-12 


\begin{abstract}
Abstrakt
Prezentovaná štúdia sa zaoberá výskumom pracovnej neistoty. Pracovnú neistotu v tomto kontexte vymedzujeme ako vnímanie hrozby, že jedinec stratí svoju prácu.
\end{abstract}

Ciele. Ciel'om štúdie je v súvislosti s protichodnými zisteniami o miere pracovnej neistoty na Slovensku analyzovat' aktuálnu úroveň pracovnej neistoty v našich podmienkach. Zároven̆ boli analyzované pričiny pracovnej neistoty.

Metóda. V nadväznosti na zistenia o výskyte, intenzite a súvislostiach pracovnej neistoty bol uskutočnený výskum pracujúcej populácie pomocou online panelu na vzorke 1010 respondentov, z toho 508 žien a 502 mužov.

Výsledky. Výsledky štúdie naznačujú, že úroveň pracovnej neistoty je podmienená najmä metódou jej zistovania. Z faktorov pracovnej neistoty sa popri tradičných sociodemografických prediktoroch na jej úrovni podiel’ali faktory zmien v organizácii, kompetencie a vplyv jedinca na prácu.

Limity. Limitom štúdie ako aj získaných výsledkov je zber údajov len u použivatelov internetu.

Kl'účové slová. pracovná neistota; pracovné podmienky; sociodemografické prediktory

\title{
Úvod
}

Pracovnú neistotu môžeme charakterizovat' ako vnímanie hrozby, že jedinec stratí prácu, alebo kontinuity pracovného miesta do budúcna. DeWitte (2005) vymedzuje niekol'ko charakteristík, ktoré sú spoločné pre rôzne prístupy k pracovnej neistote. Prvou je subjektivita jedinca, ktorá je založená na vnímaní a interpretácii jeho aktuálnej pracovnej situácie. Ďalšou je neurčitost' ohl'adom budúcnosti, resp. kontinuity práce. Tret’ou spoločnou črtou je jej nedobrovol’ný charakter. Vymedzenie pracovnej neistoty nesúvisí len s hrozbou straty práce, ale zahíňa aj ohrozenie klúčových charakteristík práce ako napr. mzda, kompetencie a pod. Ako uvádzajú Leka a Jain (2010) pracovná neistota predstavuje jeden z kl'účových psychosociálnych rizikových faktorov na pracovisku, ktorý má zásadný vplyv na zdravie a subjektívnu pohodu zamestnancov.

\section{Výskyt pracovnej neistoty}

Ako uvádza Shoss (2017), napriek vel'kému počtu štúdií o pracovnej neistote, mnoho z nich prináša výsledky o jej výskyte s limitovanou validitou s ohl'adom na vel'kosti vzoriek ako aj ich reprezentatívnost'. Túto nevýhodu eliminujú dáta medzinárodných komparatívnych projektov. Lübke a Erlinghagen (2014) skúmali pracovnú neistotu na základe dát projektu European Social Survey (ESS) z rokov 2004 a 2010. Miera pracovnej neistoty sa v roku 2004 pohybovala v rozsahu od 7,1 \% v Slovinsku po 45,3\% na Slovensku s priemerom na úrovni $16,1 \%$. V roku 2010 to bolo v rozpätí od 3,3\% v Estónsku po 48,5 \% na Slovensku s priemerom $15,8 \%$.

Odlišnú distribúciu poskytujú výsledky projektu European Working Conditions Survey 
(EWCS). Berglund (2015) analyzoval dáta z 26 krajín a zistil, že najnižšie hodnoty pracovnej neistoty identifikoval v Nórsku a Dánsku a najvyššie vo východnej Európe. Kým Slovensko vo výskume ESS vykazovalo najväčší podiel pracovnej neistoty, v dátach EWCS jeden z najmenších. Opačné hodnoty dosiahlo v oboch výskumoch Estónsko. Z prezentovaného sú zrejmé pomerne vel'ké rozdiely $\mathrm{v}$ miere zistenej pracovnej neistoty medzi krajinami ako aj medzi projektami.

\section{Faktory pracovnej neistoty: individuálna úroveň}

Individuálne faktory pracovnej neistoty sú najmä sociodemografické charakteristiky ako aj premenné pracovnej histórie. Najčastejšie skúmanými faktormi na individuálnej úrovni sú rod, vek, vzdelanie a dížka praxe zamestnancov. Vo vzt’ahu k rodu prevláda vo výskumných zisteniach názor o absencii jeho významu vo vzt’ahu k pracovnej neistote (Green et al., 2001, Erlinghagen, 2007). Vo vzt'ahu k veku zamestnancov doposial' nepanuje zhoda o jeho efekte na úroveň pracovnej neistoty. Niektoré výskumy vplyv veku nepotvrdili (Näswall, \& De Witte, 2003), iné naopak identifikovali klesajúcu pracovnú neistotu s rastúcim vekom (Green et al., 2001, Anderson, \& Pontusson, 2007). Vulkan (2012) v zmienenom kontexte uvádza, že vek vo vzt'ahu k pracovnej neistote nemá lineárny vzt’ah a preto má len zanedbatel'ný vplyv. Ako možné vysvetlenie uvedeného tvrdí, že pracovná neistota najviac zasahuje zamestnancov vo veku 30 - 50 rokov, ktorí majú väčšie finančné záväzky a zodpovednost' za závislých členov domácností v porovnaní s mladšími a staršími pracovníkmi. Podobný priebeh má aj dížka pracovného pomeru. Zamestnanci s krátkym a vel'mi dlhým pracovným pomerom vykazujú nižšiu pracovnú neistotu. Iným významným faktorom, ktorý negatívne koreluje s neistotou, je vzdelanie resp. kvalifikácia. Ako zistili Green et al. (2001) väčšiu pracovnú neistotu prežívajú nízko kvalifikovaní zamestnanci, zamestnanci s dočasnými zmluvami a ako aj tí, ktorí majú skúsenosti s nezamestnanost'ou. Zároveň nižšiu pracovnú neistotu vykazujú členovia odborov, zamestnanci vo verejnom sektore a pracovníci väčších firiem (Mauno, \& Kinnunen, 2002). Doposial' málo prebádanou oblast'ou sú faktory na úrovni osobnosti a motivácie.

V nadväznosti na protichodné zistenia o miere pracovnej neistoty na Slovensku nás zaujímala aktuálna úroveň pracovnej neistoty na Slovensku. Tiež sme analyzovali príčiny pracovnej neistoty.

\section{Metóda}

Výskum bol realizovaný v mesiacoch júl a august 2018 prostredníctvom online panelu na vzorke 1010 pracujúcich respondentov, z toho 508 žien a 502 mužov. Výber tvorili respondenti vo veku 19 až 65 rokov $(M=39,87, S D=13,75)$. Priemerný vek mužov bol 40,88 $(\mathrm{SD}=10,81)$ a žien 38,88 ( $\mathrm{SD}=12,76)$. Zároveň bolo kontrolované vzdelanie ako aj ich regionálne zastúpenie.

Pracovná neistota bola skúmaná pomocou dvoch metodík. Job Insecurity Scale (De Witte, 2000) a jej revidovanej verzie Revised Job Insecurity Scale (Barnard, 2014).

Job Insecurity Scale (JIS) skúma kvantitatívnu pracovnú neistotu, pričom zohl'adňuje 
kognitívny prístup „Myslím, že môžem stratit’ svoju prácu v blízkej budúcnosti“ ako aj afektívny prístup „Cítim sa neisto ohl'adom budúcnosti mojej práce“. Škálu tvoria 4 položky, po dve pre každú dimenziu. Respondent odpovedá na 5 bodovej škále. Škála bola výskumne otestovaná $\mathrm{v}$ rôznych jazykových mutáciách a na rozličných populáciách (Vander Elst, De Witte, \& De Cuyper, 2014). Autori uvádzajú uspokojivé výsledky konštruktovej a kritériovej validity ako aj vnútornej konzistencie škály v rozmedzí $0,82-0,88$.

Revised Job Insecurity Scale (RJIS) vznikla ako odpoved' na požiadavku komplexnejšie skúmat' kvantitatívnu pracovnú neistotu. Celkovo je tvorená 17 položkami, ktoré respondent hodnotí na 5 bodovej likertovej škále. Škálu pôvodne upravili Pienar et al. (2013) a neskôr doplnil Barnard (2014). Autor revidovanej verzie uvádza hodnotu vnútornej konzistencie $\alpha=0,86$ pre pozitívnu aj negatívnu čast’ škály.

Psychological Empowerment (Spreitzer, 1995) je škála ktorú tvoria 4 subškály s celkovým počtom 12 položiek. Jednotlivé subškály sú zamerané na 1 . význam práce, 2 . kompetencie, 3. autonómiu a 4. vplyv. Respondenti odpovedajú na položky na 5 bodovej škále. Vnútornú konzistenciu jednotlivých subškál autor udáva v rozsahu $0,81-0,88$.

Osobitnú skupinu tvorili tri položky, ktoré mapovali zmeny v práci za posledných 12 mesiacov: 1. plat alebo príjem 2. rozsahu vplyvu nad svojou prácou 3. v pracovných úlohách a povinnostiach. Respondenti odpovedali na 5 bodovej škále, kde 1=podstatne zvýšil, 5=podstatne znížil.

Zároveň boli zist’ované základné sociodemografické informácie, informácie o závislých osobách ako aj informácie o počte odpracovaných rokov, type pracovnej zmluvy, sektore, príjme a pod. Dáta boli analyzované metódou viacnásobnej lineárnej regresie.

\section{Výsledky}

V prvej časti analýzy sme zist'ovali aktuálnu mieru pracovnej neistoty v slovenských podmienkach, ktorá dosahovala úroveň $14,9 \%$ (RJIS) resp. 18\% (JIS).

V d'alšej časti sme overovali v literatúre diskutované prediktory pracovnej neistoty v slovenskom pracovnom kontexte. V tejto súvislosti sme pre potreby analýzy vytvorili dva modely pracovnej neistoty, ktoré vychádzali zo sociodemografických premenných, atribútov práce a psychologických premenných. Prvý model skúmal vplyv sociodemografických charakteristík na vnímanie pracovnej neistoty. Ako vyplýva z prezentovaných výsledkov prvý model $\mathrm{F}(7,881)=18,61, \mathrm{p}<0,001$, vysvetlil $\mathrm{R}^{2}=13 \%$ variancie. Ako významné sa vo vzt’ahu $\mathrm{k}$ pracovnej neistote prejavili vek, názor na príjem a typ pracovnej zmluvy. Naopak, nevýznamným prediktorom bol napriek očakávaniam sektor zamestnania.

Druhý model $\mathrm{F}(12,869)=33,05, \mathrm{p}<0.001$, po pridaní motivačných prediktorov psychologického posilnenia ako aj zmien za posledných 12 mesiacov zvýšil svoju explanačnú hodnotu na $\mathrm{R}^{2}=31 \%$ variancie. Ako významné sa ukázali faktory zmien v organizácii, kompetencie a vplyv jedinca na prácu. 
Tabul'ka 1. Regresná analýza prediktorov pracovnej neistoty

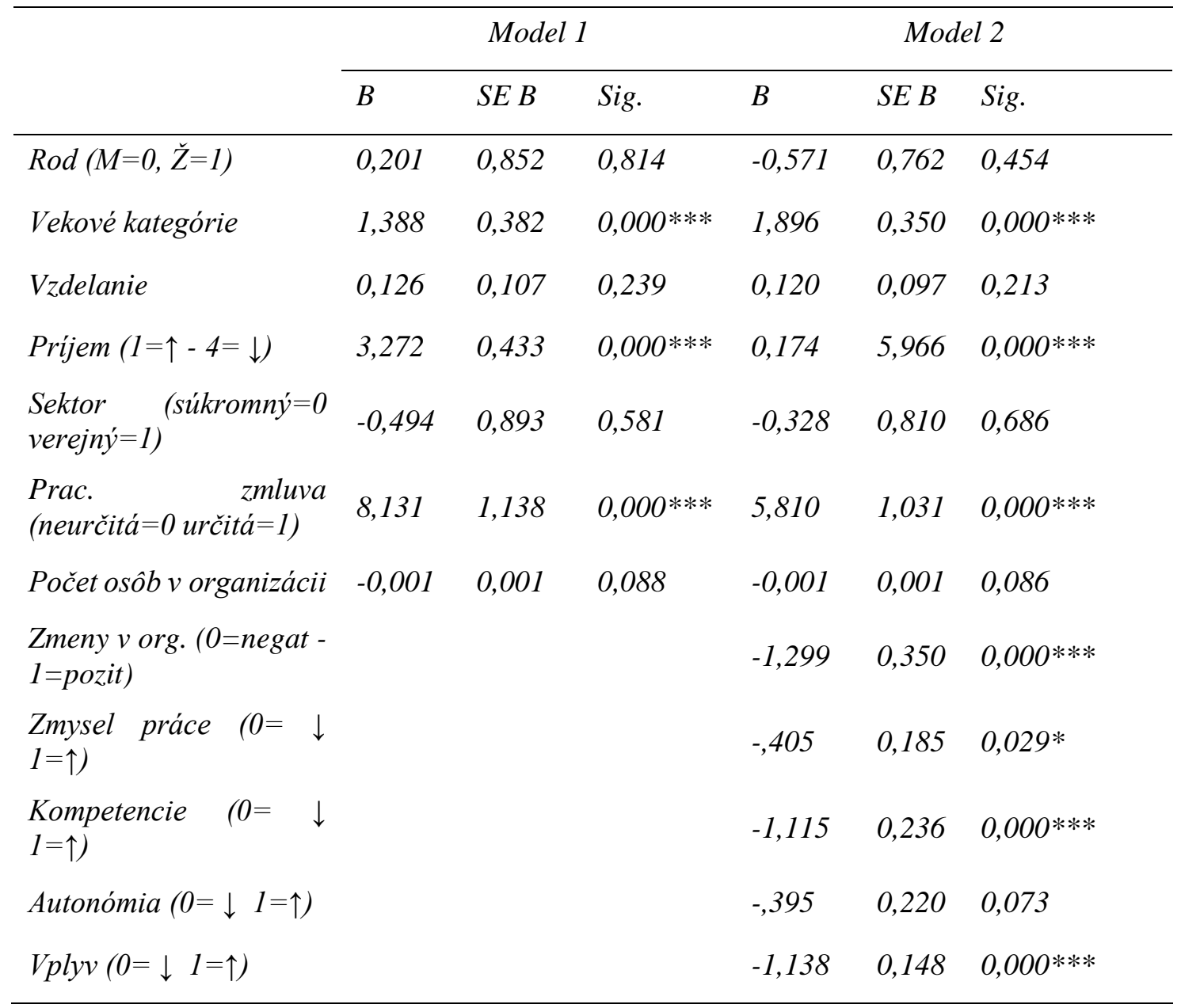

\section{Diskusia}

Z prezentovaných výsledkov vyplýva viacero záverov. Zo skúmaných prediktorov individuálnej úrovne, $\mathrm{v}$ súlade s očakávaniami, nebol vo vzt'ahu k pracovnej neistote významný rod. Výsledky výskumov vplyv rodu potvrdili len čiastočne (Ištoňová, 2015) alebo ho vôbec nepotvrdili (Berntson, Näswall, \& Sverke, 2010; Lübke, \& Erlinghagen, 2014). Keim et al. (2014) vo svojej metaanalýze uvádzajú korelačný koeficient na úrovni -0,03, získaný z 39 vzoriek respondentov. Vek sa naopak ukázal ako významný. Aj napriek tomu, že v literatúre nepanuje zhoda ohl'adom vzt'ahu veku a pracovnej neistoty, väčšina výskumov vplyv veku nepotvrdila. Vo vzt’ahu k vzdelaniu sme nezaznamenali významný koeficient, hoci výskumy prinášajú zmiešané výsledky. Čast' výskumov potvrdzuje súvislost' nižšieho dosiahnutého vzdelania a pracovnej neistoty (Moore, Grunberg, \& Greenberg, 2004), čast' naopak zistila reverzný vzt’ah (Kinnunen, Mauno, \& Siltaloppi, 2010). Keim et al. (2014) analyzovali vzt'ah vzdelania a pracovnej neistoty $\mathrm{v}$ celkovo 21 vzorkách a výsledná hodnota korelačného koeficientu bola -,03. Aj napriek tomu, že problematika príjmu nebýva bežnou súčast'ou výskumov pracovnej neistoty, prezentované výsledky ukazujú, že príjem je významným prediktorom. Ako uvádza Shoss, (2017) ekonomická vulnerabilita jedinca môže byt' zásadným 
faktorom pre vnímanie pracovnej neistoty. Finančný stres teda nepôsobí negatívne len na pracovnú neistotu, ale aj na celkovú osobnú pohodu jedinca (Ervasti, \& Venetoklis, 2010).

V spojitosti pracovnej neistoty a verejného resp. súkromného sektora existujú predpoklady o nižšej úrovni pracovnej neistoty vo verejnom sektore (Mauno, \& Kinnunen, 2002; Anderson, \& Pontusson 2007), čo však výsledky v slovenských podmienkach nepotvrdili. Naopak potvrdil sa predpoklad o väčšej pracovnej neistote zamestnancov s dočasnými pracovnými zmluvami.

Druhý model analyzoval okrem tradičných prediktorov aj zmeny na úrovni organizácie ako aj motivácie. Ako uvádza Shoss, (2017, v rámci pracovnej neistoty existuje pomerne vel'a neznámych, najmä na úrovni antecendentov, ktoré doposial' neboli dostatočne preskúmané. Iným pohl'adom na uvedené je dynamika zmien v pracovnom procese, výsledkom ktorých môže byt' prežívaná pracovná neistota. Ide najmä o interakciu dynamicky sa meniaceho pracovného prostredia a jedinca, ktorý na uvedené zmeny reaguje. Aj v našom výskume sme zaznamenali zmeny $\mathrm{v}$ organizácii práce ako aj absenciu posilnenia $\mathrm{v}$ súvislosti s pracovnou neistotou.

Množstvo vysvetlenej variancie pracovnej neistoty tradičnými prediktormi dosiahla úroveň porovnatel'nú aj v iných výskumoch, napr. Ištoňová a Fedáková (2015). Uvedené zistenia je však potrebné interpretovat' v kontexte individuálnych prediktorov pracovnej neistoty. Obmedzením tohto prístupu je absencia premenných mezo úrovne (premenné na úrovni organizácie) a makro úrovne (napr. miera nezamestnanosti, či aktívne politiky trhu práce), ktoré , ako uvádza Shoss, (2017), doterajší výskum prehliadal.

\section{Literatúra}

Anderson, C. J., \& Pontusson, J. (2007). Workers, worries and welfare states: Social protection and job insecurity in 15 OECD countries. European Journal of Political Research, 46(2), 211-235. http://doi.org/10.1111/j.1475-6765.2007.00692.x

Barnard, N. B. (2014). The validation of a revised version of the Job Insecurity Scale in South Africa. Dostupné z: http://repository.nwu.ac.za/bitstream/handle/10394/14119/Barnard_NB.pdf?sequence=1

Bellou, V. (2009). Profiling the desirable psychological contract for different groups of employees: Evidence from Greece. The International Journal of Human Resource Management, 20, 810-830. 10.1080/09585190902770711

Berglund, T. (2015). Flexicurity, job insecurity, and well-being in European labor markets. In Sustainable Working Lives (pp. 145-167). Springer, Dordrecht. http://doi.org/10.1007/97894-017-9798-6 9

Berntson, E., Näswall, K., \& Sverke, M. (2010). The moderating role of employability in the association between job insecurity and exit, voice, loyalty and neglect. Economic and Industrial Democracy, 31, 215-230. http://doi.org/10.1177/0143831X09358374 
De Witte, H. (2005). Job insecurity: Review of the international literature on definitions, prevalence, antecedents and consequences. SA Journal of Industrial Psychology, 31(4), 16. http://doi.org/10.4102/sajip.v31i4.200

De Witte H (2000) Work ethic and job insecurity: Assessment and consequences for wellbeing, satisfaction and performance at work. In: Bowen R, De Witte K, De Witte H, \& Taillieu T (Eds.). From Group to Community. Leuven: Garant, 325-350.

Erlinghagen, M. (2007). Self-perceived job insecurity and social context: A multi-level analysis of 17 European countries. European Sociological Review, 24(2), 183-197. http://doi.org/10.1093/esr/jcm042

Green, F. (2011). Unpacking the misery multiplier: How employability modifies the impacts of unemployment and job insecurity on life satisfaction and mental health. Journal of health economics, 30(2), 265-276. http://doi.org/10.1016/j.jhealeco.2010.12.005

Ištoňová, L (2015). Zamestnanecká neistota v 27 krajinách v kontexte vybraných individuálnych charakteristík. In M. Rymeš \& I. Gillernová (Eds.). Psychologie práce a organizace 2015 (pp. 110-120). Praha: Matfyzpress.

Ištoňová, L., \& Fedáková, D. (2015). Predictors and consequences of job insecurity: Comparison of Slovakia and Estonia. Studies of Transition States and Societies, 7(3), 2137.

Keim, A. C., Landis, R. S., Pierce, C. A., \& Earnest, D. R. (2014). Why do employees worry about their jobs? A meta-analytic review of predictors of job insecurity. Journal of Occupational Health Psychology, 19(3), 269. http://doi.org/10.1037/a0036743

Kinnunen, U., Mauno, S., \& Siltaloppi, M. (2010). Job insecurity, recovery and well-being at work: Recovery experiences as moderators. Economic and Industrial Democracy, 31, 179194. http://doi.org/10.1177/0143831X09358366

Leka, S., \& Jain, A., (2010). Health impact of psychosocial hazards at work: an overview. Geneva: World Health Organization.

Lübke, C., \& Erlinghagen, M. (2014). Self-perceived job insecurity across Europe over time: Does changing context matter? Journal of European Social Policy, 24(4), 319-336. http://doi.org/10.1177/0958928714538215

Mauno, S. \& Kinnunen, U. (2002). Perceived job insecurity among dual-earner couples: do its antecendents vary according to gender, economic sector and the measure used? Journal of Occupational and Organizational Psychology, 75, 295-314.

http://doi.org/10.1348/096317902320369721 
Moore, S., Grunberg, L., \& Greenberg, E. (2004). Repeated downsizing contact: The effects of similar and dissimilar layoff experiences on work and well-being outcomes. Journal of Occupational Health Psychology, 9, 247-257. http://doi.org/10.1037/1076-8998.9.3.247

Näswall, K., \& De Witte, H. (2003). Who feels insecure in Europe? Predicting job insecurity from background variables. Economic and Industrial Democracy, 24(2), 189-215. http://doi.org/10.1177/0143831X03024002003

Pienaar, J., De Witte, H., Hellgren, J., \& Sverke, M. (2013). The cognitive/affective distinction of job insecurity: Validation and differential relations. Southern African Business Review, 17(2), 1-22.

Shoss, M. K. (2017). Job insecurity: An integrative review and agenda for future research. Journal of Management, 43(6), 1911-1939.

http://doi.org/10.1177/0149206317691574

Spreitzer, G. M. (1995). Psychological empowerment in the workplace: Dimensions, measurement, and validation. Academy of management Journal, 38(5), 1442-1465. http://doi.org/10.5465/256865

Vander Elst, T., De Witte, H., \& De Cuyper, N. (2014). The Job Insecurity Scale: A psychometric evaluation across five European countries. European Journal of Work and Organizational Psychology, 23(3), 364-380.

http://doi.org/10.1080/1359432X.2012.745989

Vulkan, P. (2012). Labour market insecurity: The effects of job, employment and income insecurity on the mental well-being of employees. International Journal of Organizations, 9, 169-188.

\section{Korespondující autor}

Michal Kentoš, Ph.D.

Institute of Social Sciences, CSPS SAS,

Karpatska 5, 04001 Kosice, Slovakia

kentos@saske.sk 


\title{
Job Satisfaction and Personality Characteristics in Connection with the Change of Body Constitution
}

\section{Pracovní spokojenost a osobnostní charakteristiky v souvislosti se změnou tělesné konstituce}

\author{
Klaudia Kubalovál, Ivana Toman Čerget’ová ${ }^{1}$ \\ ${ }^{1}$ Hochschule Fresenius, Banská Bystrica, Slovakia
}

\begin{abstract}
Objective. Our empirical study investigates whether there is a difference in job satisfaction in relation to targeted physical activity. It deals with the context of changes in body constitution and job satisfaction, the quality of workplace relationships and motivation to exercise. At the same time, it examines the differences in job satisfaction between men and women. It notes the impact of exercise on the personality characteristics of a person, especially on the degree of anxiety, the rate of depression, in the period before starting with regular exercise and after repeated physical activity for 4 months.
\end{abstract}

Method. 77 respondents participated in the research, where differences in the level of job satisfaction were detected before and after regular sports activities. The sample of respondents was composed of 46 women and 31 men, with $75.3 \%$ of participants aged 20-30. In terms of work orientation, the research sample is divided into $52 \%$ of technical professions and $25 \%$ of assisting professions. In research, we use Zung's self-assessment scale of depression, Beck's anxiety inventory, five-factor personality model - Big Five and Body Mass Index.

Results. In the study, we point to the interrelationships between variables. We deal with the positive link between exercise and job satisfaction. At the same time, we point out the positive relationship between job satisfaction, motivation to performance and the quality of workplace relationships.

Conclusions. Research points out that physical and psychological conditions largely affect the survival and behavior of man in the workplace.

Limits. The results of the study could be affected by the understanding of the questionnaire. It is possible that respondents have responded to their feelings directly after exercise. This aspect could affect the responses in the variables depressive and anxiety.

Keywords. job satisfaction; physical activity; performance motivation; relationship in work enviroment

https://doi.org/10.5817/CZ.MUNI.P210-9488-2019-13 


\begin{abstract}
Abstrakt
Ciele. Naša empirická štúdia zistuje, či nastane rozdiel v miere pracovnej spokojnosti v súvislosti s cielenou pohybovou aktivitou. Zaoberá sa súvislost'ami zmeny telesnej konštitúcie a pracovnej spokojnosti, kvality vztahov na pracovisku a motivácie $k$ výkonu. Zároveň skúma rozdiely v miere pracovnej spokojnosti medzi mužmi a ženami. Všima si vplyv cvičenia na osobnostné charakteristiky človeka, najmä na mieru úzkosti, mieru depresivity, a to v období pred začatím s pravidelným cvičením a po opakovanej pohybovej aktivite v trvaní 4 mesiacov.
\end{abstract}

Metóda. Výskumu sa zúčastnilo 77 respondentov, u ktorých sa zistovali rozdiely v miere pracovnej spokojnosti pred a po vykonávani pravidelnej športovej aktivity. Vzorka respondentov bola zložená z 46 žien a 31 mužov, pričom 75,3\% účastníkov bolo vo veku od 2030 rokov. Z hl'adiska pracovného zamerania výskumnú vzorku členíme na 52\% technických profesií a 25\% pomáhajúcich profesií. V rámci výskumných metód použivame po výskume Zungovu sebaposudzovaciu stupnicu depresie, Beckov inventár úzkosti, pätfaktorový model osobnosti - Big Five a Body Mass Index.

Výsledky. $V$ štúdii poukazujeme na vzájomné vzt’ahy medzi jednotlivými premennými. Zaoberáme sa pozitívnou súvislostou medzi cvičením a pracovnou spokojnostou. Zároveñ poukazujeme na pozitívny vzt'ah medzi pracovnou spokojnost’ou, motiváciou k výkonu a kvalitou vztahov na pracovisku.

Závery. Výskum poukazuje na to, že fyzický a psychický stav do vel'kej miery ovplyvňuje prežívanie a správanie človeka na pracovisku.

Limity. Výsledky štúdie mohli byt’ ovplyvnené poňatím dotazníka. Je možné, že respondenti vzt'ahovali svoje odpovede na pocity priamo po cvičení. Tento aspekt mohol ovplyvnit' odpovede v premenných depresivita a úzkost'.

Kl’účové slová. pracovná spokojnost'; pohybové aktivity; motivácia k výkonu; vzt'ahy na pracovisku

\title{
Teoretické východiská
}

Všetky veci majú určitý tvar a ten tvar so sebou nesie svoj špecifický význam. Aj l'udské telo má svoju telesnú konštitúciu, ktorá zabezpečuje celkové fungovanie organizmu. Pohyb a vykonávanie bežných aktivít si častokrát uvedomujeme len podvedome. Anatómia l'udského tela súvisí s dynamickým životným procesom - tvarom skúsenosti, ktorý umožňuje vznik cítenia, myslenia a konania (Keleman, 2013). Živý organizmus sa prostredníctvom svojich pohybov vyjadruje zretel'nejšie než prostredníctvom slov (Lowen, 2017), pričom toto prepojenie tela a psychickej zložky si najviac uvedomujeme v situáciách, ked' sú naše vnútorné pocity sprevádzané telesnými prejavmi. Hybnou silou sú vždy naše emócie, ktoré hýbu nielen s našou psychikou, ale zároveň telom (Morschitzky, Sator, 2007). Celkový telesný výraz je vnímaný ako odraz celého človeka, pričom telo a jeho tvar zrkadlí osobnú a emocionálnu históriu jedinca (Greene, Goodrich-Dunn, 2004; Hartley, 2004). Biosyntéza a biodynamika (Lowen, 2017, Boadella, Frankel, Correa, 2009, Keleman, 1979, 1981, 2013) vnímajú telo osobitým spôsobom. Vnímanie seba samého je vedl'ajším produktom bunkového metabolizmu 
a tkanivového napätia zapísaného v mozgu. Tento zápis vyjadruje spôsob nášho fungovania. Tvar tkaniva tak zohráva úlohu v determinácii vlastného vnímania a cítenia.

Z aplikačného hl'adiska tejto témy $\mathrm{v}$ oblasti psychológie práce môžeme vnímat' pracovnú spokojnost' ako výrazný aspekt osobnej pohody, ktorá sa spája s diagnostickými a terapeutickými možnost’ami v pracovnom prostredí. Miera osobnej pohody je vel’mi stabilná v priebehu času a ukazuje sa, že l’udia majú pravdepodobne vnútorne nastavenú akúsi východiskovú hodnotu úrovne osobnej pohody (DeNeve \& Coper, 1998). Tvrdenia štúdií a propagátorov wellness businessu tvrdia, že wellness životný štýl môže zlepšit' morálku pracovnej sily, zlepšit' pracovný výkon, znížit' absencie, prilákat' a udržat' si zamestnancov, znížit' náklady, zvýšit' bezpečnost' pracovných síl, podporit' firemný imidž a zlepšit' plnenie spoločenskej zodpovednosti (Vogel, 2010). Zdravie je dôležitým faktorom pre aktívny a spokojný život a rovnako aj pre udržanie vyššej kvality života človeka, ktoré sa úzko viažu na príznaky depresivity a úzkosti ako negatívnych faktorov pracovnej spokojnosti.

Vo výskumnej časti sa odvolávame na fakt, že osobnostné črty Big Five súvisia $\mathrm{s}$ pracovnými postojmi a pracovnou spokojnost'ou. Podl'a Judgeho et al. (Judge, Heller, Mount, 2002), osobnostné črty ovplyvňujú všetky tri zložky postojov - kognitívnu, behaviorálnu i afektívnu. Z kognitívneho hl'adiska pôsobí na pracovné postoje vlastná interpretácia charakteristík organizácie a práce. Pri afektivite sú tieto postoje ovplyvňované emočnými skúsenost’ami a náladou.

Behaviorálne ovplyvňuje pracovné postoje dosahovanie úspechu - dobré pracovné výsledky a zvyšovanie pocitu kompetencie. Ako príklad sa často uvádza najmä pracovný výkon (Barrick, Mount, 2002) a taktiež vplyv situácií na pracovisku a výber sociálnych situácií (Judge, Heller, Mount, 2002). Vyšší pracovný výkon sa považuje za žiadúci, je oceňovaný vnútornými i vonkajšími odmenami a je spojený s dimenziou svedomitosti, extravrzie a negatívne s neuroticizmom (Barrick, Mount, 1991). Sociálne situácie na pracovisku, čím sa myslia sociálne interakcie s inými l'ud'mi a ich preferenciami, sú spojené predovšetkým s extraverziou, pretože extroverti majú tendenciu pohybovat' sa v sociálnych situáciách, ktoré im prinášajú radost' (Magnus, 1993 in Judge, Heller, Mount, 2002).

\section{Výskumná čast’}

\section{Ciele a výskumné otázky}

Ciel'om nášho výskumu bolo identifikovat' rozdiely, ktoré nastanú v pracovnej spokojnosti v súvislosti s cielenou pohybovou aktivitou po dobu 4 mesiacov. Zároveň sme sa snažili zist'ovat' súvislosti medzi premennými pracovná spokojnost', depresivita, úzkost', extraverzia, prívetivost', svedomitost', neuroticizmu a otvorenost' (Big Five). Predpokladali sme, že v súvislosti s vykonávaním pravidelnej pohybovej aktivity dôjde k zvýšeniu miery pracovnej spokojnosti a zníženiu miery úzkosti a depresivity, ktoré sa prejavia na zvýšenej motivácii a výkone $\mathrm{v}$ práci, pričom osobitne nás zaujímali rozdiely medzi účastníkmi výskumu z hl'adiska pohlavia a profesijného zamerania. 


\section{Výskumný súbor a metodika výskumu}

Výber účastníkov výskumu podliehal dlhodobej prípravnej fáze a to najmä z dôvodu, že bolo potrebné nadviazat' spoluprácu s viacerými trénermi vo fitnescentrách. Našou ciel'ovou skupinou boli osoby, ktoré sa rozhodli realizovat' pravidelnú pohybovú aktivitu, pričom podmienkou bolo, aby trénovali minimálne 3-krát týždenne po dobu 4 mesiacov. Prvého merania - pred začatím tréningového programu - sa zúčastnilo 86 osôb, ktorých počet sa pri druhom meraní - po ukončení tréningového programu - znížil na 77 respondentov ( $60 \%$ žien a $40 \%$ mužov). Väčšina účastníkov (75,3\%) bolo vo veku od 20 do 30 rokov). Z hl'adiska pracovného zamerania sme mali zastúpenie profesií pracujúcich s l'ud'mi v rozsahu $68 \%$ (učitel', psychológ, terapeut, asistent predaja, manažér, pracovník call centra). Osôb z technických profesií (pracovník výrobnej linky, strojársky technik, zvárač, programátor) sme identifikovali v nižšom zastúpení $33 \%$.

Distribúcia dotazníkov prebiehala v roku 2018, pričom prvé meranie sa realizovalo v januári 2018 a druhé meranie začiatkom júna 2018. Časový rozdiel medzi prvým a druhým meraním bol 4 kalendárne mesiace. Zber dát sme realizovali prostredníctvom viacerých štandardizovaných dotazníkov s krátkym demografickým úvodom doplneným o údaje týkajúce sa pracovného pôsobenia účastníkov výskumu. Okrem toho sme na meranie miery pracovnej spokojnosti použili vlastnú 1-položkovú škálovú otázku (10-bodová Likertova škála s vyjadrením miery súhlasu), ktorá bola prvou dotazovacou metódou (Ankur \& kol., 2015). Respondenti hodnotili nasledovné položky: Celková pracovná spokojnost' (Cronbachova $\alpha$ 0,71), Motivácia k výkonu práce (Cronbachova $\alpha$ 0,71) a Kvalita vzt’ahov na pracovisku (Cronbachova $\alpha$ 0,72). Mieru depresivity sme merali pomocou 20-položkovej Zungovej sebaposudzovacej stupnice depresie (SDS; Self Rating Depression Scale, Kane, Radosevich, 2011). Hodnota Cronbachovej a dosiahla 0,79. Ďalším použitým štandardizovaným dotazníkom bol 21-položkový Beckov inventár úzkosti (BAI; Beck Anxiety Inventory, Beck et al., 1979), ktorý umožňuje subjektívne vyhodnocovat' aktuálnu mieru úzkosti a jej somatických a psychických príznakov. Hodnota Cronbachovej $\alpha$ vo výskume dosiahla hodnotu 0,76. Osobnostné charakteristiky sme merali pomocou 44-položkového dotazníka Big Five (Goldberg, 1993). Cronbachova $\alpha$ má v jednotlivých škálach Big Five nasledovné hodnoty: extraverzia 0,74 ; prívetivost' 0,75 ; svedomitost' 0,75 ; neuroticizmu 0,76 ; otvorenost' 0,78 . Poslednou hodnotou, ktorú sme v našom výskume sledovali, bol Body Mass Index (BMI) index telesnej hmotnosti, nazývaný tiež Queteletov index, ktorým sme zist'ovali mieru telesnej hmotnosti.

\section{Výsledky výskumu}

Z výsledkov výskumu môžeme identifikovat' pokles BMI u účastníkov výskumu. Hodnoty priemerného poradia boli v prípade prvého merania na úrovni 32,97 a pri druhom meraní na úrovni $16,82(\mathrm{~W}=-4,696 ; \mathrm{p}=, 000)$. Počas tréningového programu trvajúceho 4 mesiace došlo u respondentov k výraznému úbytku telesnej hmotnosti a teda aj telesnej konštitúcie. Zároveň sme identifikovali rozdiely v premenných medzi jednotlivými meraniami. U účastníkov výskumu došlo k zvýšeniu miery pracovnej spokojnosti, motivácie k výkonu práce a kvality vzt'ahov na pracovisku. Zároveň sme zistili pokles miery depresivity a úzkosti. 
Rovnako sme identifikovali rozdiely medzi pohlaviami a taktiež v rámci profesijného zamerania na hladine významnosti $\mathrm{p}>0,05$.

Tabul'ka 1. Porovnanie jednotlivých premenných v rámci 2 meraní (Wilkoxon test)

\begin{tabular}{lccc}
\hline & Priemerné poradie & W & $\mathrm{p}$ \\
\hline Celková pracovná spokojnost' & 12,50 & $-5,718$ &, 000 \\
Motivácia k pracovnému výkonu & 22,23 & & \\
& 11,50 & $-5,555$ &, 000 \\
Kvalita vzt'ahov na pracovisku & 22,51 & & \\
& 0,00 & $-5,535$ &, 000 \\
Miera depresivity & 19,00 & & \\
& 40,88 & $-6,530$ &, 000 \\
Miera úzkosti & 15,14 & & \\
& 36,66 & $-5,702$ &, 000 \\
\hline
\end{tabular}

Tabul'ka 2. Porovnanie jednotlivých premenných v rámci 2 merani - rozdiely medzi pohlaviami (Mann-Whitneyho U test)

\begin{tabular}{lcccc}
\hline & Pohlavie & $\begin{array}{c}\text { Priemerné } \\
\text { poradie }\end{array}$ & $\mathrm{U}$ & $\mathrm{p}$ \\
\hline $\begin{array}{l}\text { Celková pracovná } \\
\text { (prvé meranie) }\end{array}$ & muži & 38,13 & 686,00 & 0,774 \\
$\begin{array}{l}\text { Celková pracovnó } \\
\text { (druhé meranie) }\end{array}$ & ženy & 39,59 & & \\
Miera depresivity & muži & 36,66 & 640,00 & 0,434 \\
(prvé meranie) & ženy & 40,58 & & \\
Miera depresivity & muži & 37,81 & 676,000 & 0,700 \\
(druhé meranie) & ženy & 39,80 & & \\
Miera úzkosti & muži & 35,48 & 604,000 & 0,257 \\
(prvé meranie) & ženy & 41,37 & & \\
Miera úzkosti & muži & 41,98 & 620,500 & 0,336 \\
(druhé meranie) & ženy & 36,99 & & \\
\hline
\end{tabular}

Výsledky nášho výskumu d'alej poukázali na negatívny vzt'ah medzi depresivitou a otvorenost'ou $(r=-0,329)$, prívetivost'ou $(r=-0,289)$ a svedomitost'ou $(r=-0,387)$. Na základe týchto výsledkov sa domnievame, že l'udia s vyššou mierou depresivity sú viac uzavretí, 
negatívne ladení a bez vyššieho záujmu o okolie. Tieto faktory môžu výrazne ovplyvňovat' samotný pracovný výkon a celkovú pracovnú spokojnost'. Zároveň sme zistili pozitívny vzt'ah medzi depresivitou a úzkost'ou $(\mathrm{r}=0,422)$ a depresivitou a neuroticizmom $(\mathrm{r}=0,513)$. Úzkost' negatívne koreluje so svedomitost'ou $(r=-0,289)$, extraverziou $(r=-0,207)$, otvorenost'ou $(r=$ $-0,191)$, prívetivost'ou $(\mathrm{r}=-0,266)$ a pozitívne s neuroticizmom $(\mathrm{r}=0,324)$.

Tabul'ka 3. Porovnanie jednotlivých premenných v rámci 2 meraní - rozdiely medzi profesijným zameraním (Mann-Whitneyho U test)

\begin{tabular}{|c|c|c|c|c|}
\hline & Pohlavie & $\begin{array}{l}\text { Priemerné } \\
\text { poradie }\end{array}$ & $\mathrm{U}$ & $\mathrm{p}$ \\
\hline $\begin{array}{l}\text { Celková pracovná spokojnost' } \\
\text { (prvé meranie) }\end{array}$ & $\begin{array}{l}\text { techn. } \\
\text { pomáh. }\end{array}$ & $\begin{array}{l}35,44 \\
40,71\end{array}$ & 561,000 & 0,321 \\
\hline $\begin{array}{l}\text { Celková pracovná spokojnost' } \\
\text { (druhé meranie) }\end{array}$ & $\begin{array}{l}\text { techn. } \\
\text { pomáh. }\end{array}$ & $\begin{array}{l}37,22 \\
39,86\end{array}$ & 605,500 & 0,615 \\
\hline $\begin{array}{l}\text { Miera depresivity } \\
\text { (prvé meranie) }\end{array}$ & $\begin{array}{l}\text { techn. } \\
\text { pomáh. }\end{array}$ & $\begin{array}{l}39,82 \\
38,61\end{array}$ & 629,500 & 0,823 \\
\hline $\begin{array}{l}\text { Miera depresivity } \\
\text { (druhé meranie) }\end{array}$ & $\begin{array}{l}\text { techn. } \\
\text { pomáh. }\end{array}$ & $\begin{array}{l}37,84 \\
39,56\end{array}$ & 621,00 & 0,752 \\
\hline $\begin{array}{l}\text { Miera úzkosti } \\
\text { (prvé meranie) }\end{array}$ & $\begin{array}{l}\text { techn. } \\
\text { pomáh. }\end{array}$ & $\begin{array}{l}42,78 \\
37,18\end{array}$ & 555,500 & 0,303 \\
\hline $\begin{array}{l}\text { Miera úzkosti } \\
\text { (druhé meranie) }\end{array}$ & $\begin{array}{l}\text { techn. } \\
\text { pomáh. }\end{array}$ & $\begin{array}{l}41,16 \\
37,96\end{array}$ & 596,000 & 0,555 \\
\hline
\end{tabular}

\section{Diskusia}

Neustále viacero zamestnávatel'ov začína prihliadat' na spokojnost' svojich pracovníkov, pričom sa snažia o hl'adanie vhodných benefitov a faktorov spokojnosti, ktorými by sa stali atraktívnymi pre pracovný trh. Vychádzajúc z teoretických východísk Kelemana (2013) sme sa snažili preukázat' súvislost' medzi pohybom a emóciami. Rovnako Mayerová (1997) vníma, že motiváciu k vyššiemu výkonu práce je možné docielit’ aj podporou zdravotných podmienok práce a zdokonal'ovaním kvality pracovného života. Zlepšovaním týchto podnetov sa úroveň stresu dostáva do správnej hladiny, zvyšuje sa motivácia zamestnancov a efektivita práce. Jedným z prostriedkov k zvýšeniu výkonnosti a kvality práce sú preventívne antistresové programy v podnikoch (Mayerová, 1997). Kollárik (1986, s.21) uvádza, že: „pracovná spokojnost' je mnohorozmerný sociálny jav, ktorý v sebe zahŕňa psychologické, ekonomické, sociologické, právne, organizačné, pedagogické a zdravotné aspekty“.

V našom prvom meraní respondentov mala celková pracovná spokojnost' hodnotu $\mathrm{M}=$ 12,50; $v$ druhom meraní sa jej hodnota zvýšila na $\mathrm{M}=22,23$. Motivácia $\mathrm{k}$ výkonu práce mala počas obdobia bez pohybovej aktivity hodnotu $\mathrm{M}=11,50$; následne stúpla na $\mathrm{M}=22,51$. Kvalita vzt'ahov na pracovisku vzrástla $\mathrm{z} M=0,00$, na $\mathrm{M}=19,00$. Zároveň pozorujeme pokles 
depresivity a úzkosti v rámci druhého merania respondentov. Rozdiel medzi týmito hodnotami je signifikantný.

Na tomto základe potvrdzujeme, že pravidelným cvičením nastáva zvýšenie pracovnej spokojnosti a zníženie depresivity a úzkosti. Opierame sa pri tom o výskum Morgena a Batha (1998), ktorý poukazuje na fakt, že l'udia, ktorí nevyvíjajú dostatočnú pohybovú aktivitu, trpia depresiami dvakrát viac ako aktívni l'udia. Potvrdili sme aj tvrdenie Harveyho (2017), ktorý uvádza, že počas cvičenia sa v mozgu uvolňujú chemické látky, ktoré dodávajú človeku pocit osobnej pohody (well-being) a pohyb môže rovnako pomôct' aj l'ud'om trpiacim úzkost'ou a depresivitou. Jeden z výskumov, o ktorý sa opierame a rovnako sme potvrdili jeho zámery, skúmal pracovnú spokojnost' na vel'kej vzorke respondentov (až 30837 l’udí) a uskutočnil pod vedením Y. Tinga (1997). Výskum poukázal na súvislosti pracovnej spokojnosti s individuálnymi osobnostnými charakteristikami zamestnancov.

Výsledky nám potvrdili, že fyzický a psychický stav do vel'kej miery ovplyvňujú celkové prežívanie a správanie človeka. Z týchto výsledkov usudzujeme, že ak človek trpí depresívnymi príznakmi, často sa s nimi spája pocit úzkosti a rôzne psychosomatické prejavy. $\mathrm{Na}$ základe našich výsledkov predpokladáme, že l'udia, ktorí vykazujú úzkostné prejavy pocit'ujú nadmerné obavy, strach, nespavost' a pocity ohrozenia. Na základe pozitívneho vzt'ahu medzi úzkost'ou a neuroticizmom usudzujeme, že tieto osoby sú podráždenejšie, majú potiaže s koncentráciou; z pychosomatického hl'adiska sa tento vzt'ah môže prejavovat' pocitmi vnútorného chvenia, červenaním alebo blednutím, potením, bolest'ami a pod.

Na základe výskumu Búgelovej a Kostelnej (2000, in Blatny, Svoboda, Ruisel, Vyrost, 2000, s.30) usudzujeme, že muži vykazujú vyššiu mieru pracovnej spokojnosti ako ženy. Tento predpoklad sa nám vo výsledkoch nepotvrdil. Jedným z dôvodov mohol byt' pomer žien a mužov v našom výskume. Predpokladali sme, že ženy majú vyššiu mieru depresivity a úzkosti ako muži. Vychádzali sme z viacerých štatistík, ktoré ženy v týchto dvoch diagnózach označujú ako rizikovejšiu skupinu. V našom výskume výsledky hovoria, že ženy majú vyššiu mieru depresivity, ale vyššiu mieru úzkosti majú muži. Takéto výsledky sa môžu odvíjat' od jednotlivých položiek v dotazníku, ktoré respondenti hodnotili. Niektoré položky zist'ovali mieru potenia, búšenia srdca, dýchavičnosti. Ak respondenti (muži) hodnotili tieto faktory na základe pocitov po cvičení, môže to byt' dôvod zvýšeného skóre v miere úzkosti u mužov.

$\mathrm{V}$ našom porovnaní sme nezískali štatisticky významné rozdiely medzi typmi profesijného zamerania. Napriek tomu je dôležitá včasná prevencia znižovania stresu aj pohybovou aktivitou. Predčasné opatrenia sú omnoho jednoduchšou cestou k spokojnosti človeka.

Jednotlivé premenné, ktoré sme vo výskumnej časti práce sledovali navzájom súvisia. Ukázalo sa, že rovnako vel'ký súvis má aj pravidelnost' pohybových aktivít. Naši respondenti cielene cvičili minimálne trikrát týždenne. $V$ dôsledku pravidelného cvičenia nastala u našich respondentov ret’azová reakcia. Už po prvých týždňoch sa začali cítit' lepšie, čo bolo spôsobené najmä vyplavovaním endorfínov. Ich nálada bola pozitívnejšia, zvýšila sa celková osobná pohoda. Tento stav zároveň viedol ku kvalitnejšiemu spánku, lepšej regenerácii tela a ráno $\mathrm{k}$ zvýšenej miere energie. Predpokladáme, že tieto faktory následne ovplyvnili aj pracovný výkon, motiváciu a efektivitu na pracovisku. 


\section{Záver}

Svetové aj slovenské výskumy sa dnes vo vel'kej miere zaoberajú skúmaním faktorov pracovnej spokojnosti, nakol'ko spokojní zamestnanci sú jednou z najväčších konkurenčných výhod na trhu. Naša výskumná štúdia sa pokúsila zistit', či sa zvýši miera pracovnej spokojnosti na základe pravidelnej pohybovej aktivity počas 4 mesiacov sledovania. Na základe výsledkov našej štúdie môžeme potvrdit' zvýšenie celkovej pracovnej spokojnosti, motivácie k výkonu a kvality vzt'ahov na pracovisku. Rovnako sme potvrdili vzájomnú súvislost' s premennými depresivita a úzkost', ktorých úroveň sa u našich respondentov znížila medzi prvým a druhým meraním. Limity nášho výskumu vidíme najmä v nezrovnalosti v poňatí dotazníka. Je možné, že respondenti vzt'ahovali svoje odpovede najmä na pocity priamo po cvičení. Tento faktor mohol výrazne ovplyvnit' odpovede v premenných depresivita a úzkost'. Ďalším významným faktorom, ktorý sme z dôvodu náročného získavania respondentov nezaznamenávali je dížka aktuálneho pracovného pomeru. Niektorí respondenti boli zamestnaní v prebiehajúcom zamestnaní niekol'ko rokov, iní len niekol'ko mesiacov. Ak by bola vzorka respondentov vyberaná aj podl'a tohto kritéria, je možné, že hodnoty v miere pracovnej spokojnosti by boli kompaktnejšie. Opierajúc sa o teoretické východiská našej štúdie môžeme záverom konštatovat', že zmena tvaru tela tvaruje aj emócie človeka a z daného dôvodu je tento aspekt významný pri podpore pracovnej spokojnosti zamestnancov.

\section{Literatúra}

Ankur, J., Saket, K., Satish, Ch., \& Pal, D. K. (2015). Likert Scale: Explored and Explained. British Journal of Applied Science \& Technology, 7(4), 396-403. http://doi.org/10.9734/BJAST/2015/14975

Barrick, M.R., \& Mount, M.K. (1991). The big five personality dimensions and the job performance of sales representatives: The test of the mediating effects of goal setting. Journal of Applied Psychology, 78, 715-722. http://doi.org/10.1037/0021-9010.78.5.715

Beck, A.T. (1979). Cognitive therapy and the emotional disorders. New York: Penguin Book.

Boadella, D., Frankel, E., Correa, M. (2009). Biosyntéza - výběr z textů. Praha: Triton.

Búgelová, T., Kostelná, Z. (2000). Determinanty pracovnej spokojnosti a osobnost'. In: Blatny, M., Svoboda, M., Ruisel, I. Vyrost, J. (2000). Sociální procesy a osobnost. Sborník př́spěvku. Brno: Masarykova univerzita.

DeNeve, K.M., Coper, H. (1998). The happy personality: A meta analysis of 137 personality traits and subjective well-being. Psychological Bulletin, 124, 197-229. http://doi.org/10.1037/0033-2909.124.2.197

Greene, E., Goodrich - Dunn, B. (2004). Psychology of the Body. Philadeplphia: Lippincott Williams \& Wilkins.

Hartley, L. (2004). Somatic psychology - Body, mind and meaning. London and Philaadelphiaa: Whurr Publishers. 
Judge, T.A., Heller, D., Mount, M.K. (2002). Five-Factor Model Of Personality and Job Satisfaction: A Meta-Analysis. Journal od Applied Psychology, 87(3), 530-541. http://doi.org/10.1037/0021-9010.87.3.530

Kane, L.R., Radosevich, D.M. (2011). Conducting Health Outcomes Research. Canada: Jones and Barlett Learning.

Keleman, S. (1979). Somatic Reality. Berkeley: Center Press.

Keleman, S. (1981). Your body speaks its mind. Berkeley: Center Press.

Keleman, S. (2013). Anatomie emocí. Emoce a jejich vliv na lidské tělo. Praha: Portál.

Kollárik, T. (1986). Spokojnost’v práci. Bratislava: Práca.

Lowen, A. (2017). Jazyk těla. Tělesná dynamika charakterových struktur. Praha: Portál.

Mayerová, M. (1997). Stres, motivace a výkonnost. Praha: Grada Publishing.

Morgan, K., Bath, P. (1998). Customary physical activity and psychological wellbeing: a longitudinal study. Age and ageing. 27(3), 35-40.

http://doi.org/10.1093/ageing/27.suppl_3.35

Morschitzky, H. Sator, S. (2007). Když duše mluví řečí těla. Stručný přehled psychosomatiky. Praha: Portál.

Ting, Y. (1997). Determinanats of job satisfaction of federal government employees. Public Personnel Management, 26(3), 313-334. http://doi.org/10.1177/009102609702600302

Vogel, J.R. (2010). Wellness as a business strategy. Strategic HR Review, 16(1), 13-16.

\section{Korespondující autor}

Bc. Klaudia Kubalová, M.Sc.

Hochschule Fresenius

Cesta na štadión 7, 97404 Banská Bystrica, Slovakia

klaudia.kubalova@gmail.com 


\title{
Perception of motorbike riding safety in Taiwan and the Czech Republic
}

\section{Vnímání bezpečnosti řízení motocyklů na Taiwanu a v České republice}

Václav Linkov ${ }^{1}$, Vit Gabrhel ${ }^{1}$, Chun-Hua Hü \& Shiao-Tzu Ma ${ }^{2}$

${ }^{1}$ Centrum dopravního výzkumu, v.v.i., Česká republika

${ }^{2}$ Graduate Institute of Injury Prevention and Control, College of Public Health, Taipei Medical University, Republic of China

\begin{abstract}
Objective. Perception of traffic safety might differ in various cultures. If we study what people in various cultures consider to be important for safe riding, we might enhance our ability to prepare good traffic infrastructure.

Method. Sample consisted from 122 Czech and 57 Taiwanese motorcycle or scooter riders. They filled questionnaire with 31 items about how much risky for riders they consider various traffic issues and how often they engage in risky driving activities. Answers of Czech and Taiwanese participants were compared using Mann-Whitney $U$.

Results. Czech riders consider behavior of other drivers to be larger risk for traffic safety than it is considered by Taiwanese riders. Taiwanese riders consider their own riding behavior to be more risky than Czech riders. Taiwanese riders consider themselves to be better riders than Czech riders, they also think (in comparison with Czechs) that they have fewer patience with other drivers and get more easily angry. Taiwanese riders more often agree that they overtake cars from the right side. Czech riders more often than Taiwanese engage in activities allowing to use driving skills like overtaking cars during traffic jam by riding between two lines of cars or riding through solid line in curves.
\end{abstract}

Conclusions. It might be beneficial if Taiwanese riders get information about safe overtaking before riding in the Czech Republic.

Limitations. Main limitation is small sample especially in Taiwan. Also, samples in both cultures were collected in different ways. Questionnaire used was constructed for the Czech sample, we didn't use any internationally used questionnaire.

Keywords. Motorbike riders; Traffic safety; Czech Republic; Taiwan.

https://doi.org/10.5817/CZ.MUNI.P210-9488-2019-14 


\begin{abstract}
Abstrakt
Cíl. Vnímání dopravní bezpečnosti se liši v jednotlivých kulturách. Pokud studujeme, co lidé $v$ různých kulturách považují za důležité pro bezpečnou jízdu, můžeme zlepšit naši schopnost vytváret dobrou dopravní infrastrukturu.
\end{abstract}

Metoda. Výzkumný soubor tvořilo 122 českých a 57 taiwanských aktivních řidičů motocykli̊ nebo skútrů, kteři vyplnili dotazník se 31 položkami tázajicimi se, co považují respondenti za rizikové při jízdě na motocyklu/skútru a jak často se při řizení dopouštěji různých rizikových aktivit. Odpovédi českých a taiwanských respondentủ byly porovnány s pomocí Mann-Whitney $U$.

Výsledky. Čeští motocyklisté považují více než taiwanští za riziko pro bezpečnost chování ostatnich řidičư, ale méně vlastní řidičské chování. Taiwanští motocyklisté považují své vlastní řidičské chování za riskantnější než čeští motocyklisté, dále se považuji za lepši řidiče než čeští, oproti českým si myslí, že mají méně trpělivosti s ostatními řidiči a snadněji se rozčilí, dále více souhlasí s tím, že častěji predjižzěji vozidla zprava. Čeští motocyklisté se častěji věnují aktivitám umožňujícím předvést manévrovací schopnosti jako např. projižděni kolony mezi vozidly nebo přejižděni pres plnou čáru v zatáčkách.

Závěry. Může být užitečné, aby taiwanští motocyklisté dostali informace o bezpečném predjižděni predtím, než ř́dí $v \check{C} R$.

Limity. Hlavním limitem je malý vzorek na Taiwanu. Dále, vzorky v obou zemích byly získány rozdílným způsobem. Použitý dotazník byl vytvořen pro český vzorek, nejde o mezinárodně využivaný dotazník.

Klíčová slova. Řidiči motocyklů; dopravní bezpečnost; Česká republika; Taiwan.

\title{
Úvod
}

Bezpečnost řízení jednostopých motorových vozidel představuje jednu z nejdůležitějších oblastí bezpečnosti silničního provozu, např. na Taiwanu představují úmrtí řidičů motocyklů a skútrů kolem 40\% úmrtí při dopravních nehodách (Lin, Chang, Pai \& Keyl, 2003). Výzkumu faktorů ovlivňujících bezpečnost řízení motorek a skútrů se proto věnuje hodně prostoru. Větší riziko nehody existuje u mladších motocyklistů (Lin et al., 2003) a motocyklistů, kteří jsou hůře viditelní (Pai, 2011). Jezdci vnímají jako nebezpečnější řízení na venkově než ve městě, protože vyšší povolená rychlost svádí k nebezpečné jízdě v často obtížnějších podmínkách (Musselwhite et al., 2012). Motocyklisté proškolení v pokročilém ovládání motocyklu jezdí v nebezpečných místech pomaleji než stejně zkušení motocyklisté, kteří proškoleni nebyli (Crundall, Stedmon, Saikayasit \& Crundall, 2013). Agresivní jízda u motocyklistů je menším problémem než u řidičů osobních aut (Rowden et al., 2016). Nebezpečná jízda u motocyklistů nejvíce souvisí (na rozdíl od řidičů osobních aut) s tím, že na motocyklu jezdí, protože jim to přináší vzrušení a zážitky (Jevtić et al., 2012).

Jízda na motocyklu je negativně ovlivněna po konzumaci alkoholu, zejména při obtížnějších jízdních úkonech. Řidiči pod vlivem alkoholu zejména pomaleji reagují na 
nebezpečí, jezdí rychleji v zatáčkách, častěji přejíždějí čáry a jezdí blíže ke sloupkům ohraničujícím silnici (Creaser, Ward, Rakauskas, Shankwitz \& Boer, 2009). Řízení pod vlivem alkoholu tak vede k větší pravděpodobnosti zranění a úmrtí při dopravní nehodě (Chen \& Pai, 2019; Chen, Chen \& Pai, 2018).

Bezpečnost motocyklistů může zvýšit i promítání jízdy z pohledu motocyklisty řidičům automobilů, kteří pak lépe chápou, které situace jsou pro motocyklisty nebezpečné a mohou se tak vůči nim chovat bezpečněji (Shahar, Clarke \& Crundall, 2011). Jízda motocyklistů se rovněž stane bezpečnější, pokud jsou na rizikové situace trénováni na řidičském simulátoru (Vidotto, Bastianelli, Spoto \& Sergeys, 2011).

Dle názoru motocyklistů nejsou různé styly jízdy nebezpečné samy o sobě, ale záleží na jízdních schopnostech jezdce, stavu vozovky, jízdních podmínkách, kapacitě motocyklu a jeho jízdních vlastnostech apod. Nebezpečná je únava jezdce. Mezi nebezpečné manévry dle motocyklistů patři přjejíždění plných čar, zejména při naklánění se při zatáčení. Řidiči dvoustopých vozidel motocyklisty ohrožují udržováním př́iliš krátké vzdálenosti za nimi nebo předjížděním v momentě, kdy je předjíždí motocykl. Při předjíždění automobilu je tak vhodné se ujistit, že řidič motocyklistu viděl (Huth, Füssl \& Risser, 2014). Nejvíce nebezpečným manévrem je jízda s akrobatickými prvky, např. na zadním kole (Özkan et al., 2012). Rizikovými situacemi při běžné jízdě jsou dále změna jízdního pruhu, když jiný řidič nerespektuje motocyklistovo právo přednosti v jízdě, nečekaná změna pruhu nebo zpomalení vozidla vepředu, otáčení motocyklu po startu nebo jízda ve větru (Aupetit et al., 2016).

V prezentovaném výzkumu jsme se zajímali o to, jak se liší vnímání závažnosti různých faktorů ovlivňujících bezpečnost jízdy a vnímání vlastního jízdních stylu v České republice a na Taiwanu. Za tímto účelem jsme v obou zemích distribuovali dotazník.

\section{Metoda}

\section{Vzorek}

V České republice výzkumný soubor tvořilo 122 účastníků kurzu bezpečné jízdy pro řidiče motorek a skútrů v roce 2016. Kurzu se zúčastnilo celkově 410 osob, 341 mužů a 69 žen, průměrný věk 37 let $(S D=9,5)$. O pohlaví a věku těch z nich, kteří vyplnili dotazník, nemáme informace. Na Taiwanu byl výzkumný soubor získán v roce 2018 tak, že byl dotazník umístěn na internet a následně byli obesláni studenti Graduate Institute of Injury Prevention and Control na Taipei Medical University, aby jej vyplnili. Následně byl dotazník se žádostí o vyplnění umístěn rovněž v taiwanských motorkářských diskusních skupinách na Facebooku. Výsledný soubor tvořilo 57 respondentů, 37 mužů a 17 žen (u 3 respondentů informaci o pohlaví nemáme), průměrný věk 27 let $(\mathrm{SD}=9,3$; u 4 respondentů nemáme informaci o věku).

\section{Dotazník}

Dotazník byl vytvořen pro účel zjišt'ování názorů motocyklistů navštěvujících kurzy bezpečné jízdy. V ČR jsme použili dotazník v papírově podobě. Dotazník měl dvě části, první část, v níž respondenti odpovídali na pětistupňové škále „není rizikové“ - „extrémně rizikové“, lze nalézt $v$ tabulce 1 . V druhé části respondenti vyznačili na čtyřstupňové škále ,úplně 
nesouhlasím“ - „úplně souhlasím“ svůj souhlas s položkami, které jsou uvedeny v prvním odstavci části výsledky.

Na Taiwanu jsme použili tento dotazník, který byl nejprve přeložen do čínštiny, načež byl čínský překlad zkontrolován a upraven prvním autorem. Následně byl umístěn na web.

\section{Výsledky}

Položky dotazníku byly zpracovány faktorovou analýzou s polychorickými korelacemi s extrakcí metodou nejmenších čtverců (minres) a rotací geominQ. Protože první faktor obsahoval pouze (a všechny) položky z první části dotazníku a v př́ípadě faktorové analýzy pouze na této první části dotazníku vyhovovalo pouze jednofaktorové řešení (což při interpretaci nedávalo smysl), analyzovali jsme tuto první část zvlášt' po jednotlivých otázkách. Při faktorové analýze druhé části dotazníku jsme na základě scree plotu vybrali čtyřfaktorové řešení (RMSEA index $=0,11$ ). Do jednotlivých škál jsme zařadili položky, které v daném faktoru měly náboj alespoň 0,4 . První faktor sytil položky „Je jen málo řidičů, kteří v provozu na silnici reagují lépe než já“, „Řídím líp než většina ostatních řidičưu, „Nečekané situace v provozu zvládám lépe než ostatní řidiči“, „Sám/a dopravní nehodu nezaviním“, „Při řízení jsem nikdy nezapochyboval/a“ (McDonald's omega 0,84). Tento faktor jsme nazvali „důvěra ve vlastní řidičské schopnosti“. Druhý faktor sytil položky „Pro bezpečnou jízdu mě nemusí vidět ostatní řidiči. Stačí, že vidím já je“, „V náročnějších situacích jedu raději opatrněji, než abych riskoval“ (R), „Před křižovatkou zvyknu zpomalit“ (R), „Ani v náročnějších situacích se nebojím při jízdě na motocyklu riskovat“, „Když mám ve výhledu horizont, snížím svou rychlost“ (R) (omega 0,72). Tento faktor jsme nazvali „ochota riskovat“. Třetí faktor sytil položky „Když je prázdná silnice, při projíždění zatáčkou si najedu do protisměru“, „Když je na to na silnici prostor, předjíždím po středové čářre“, „Při jízdě na motocyklu mám rád výzvy“, „Povolenou rychlost nikdy nepřekračuji“ (R), „Při jízdě na motocyklu vyhledávám trasy, které jsou pro mě výzvou“, ,Je-li kolona, projedu ji mezi vozidly“ (omega 0,71). Tento faktor jsme nazvali „využívání řidičských dovedností“. Čtvrtý faktor sytily položky „Jednání některých řidičů mě dokáže rozčílit“, „Mám trpělivost pro řidiče, kteří neumějí dobře jezdit“ (R), „Když mě opravdu rozčílí jednání druhého řidiče nebo chodce, dám mu najevo, co si o něm myslím“ (McDonald omega 0,71). Tento faktor jsme nazvali „hostilita vůči ostatním řidičům“. Položky „I když spěchám, nemá to vliv na styl mé jízdy“ a „Předjedu vozidlo zprava, když je na to dostatek místa“ nebyly v požadované míře syceny žádným z faktorů, proto jsme je analyzovali zvlášt'.

Položky sycené faktory 1 až 4 z odstavce výše jsme analyzovali jako škály. Na základě Shapiro-Wilkova testu jsme u všech čtyř škál zamítli hypotézu, že dané skóry mají normální rozložení. Proto jsme rozdíly mezi odpověd'mi v obou zemích porovnávali s pomocí MannWhitney U jak u skórů vzniklých ze čtyř škál, tak u deseti položek z první části a dvou samostatně analyzovaných z druhé části dotazníku. Při celkové počtu šestnácti porovnání jsme použili Bonferroniho korekci, zvolili jsme tedy hladinu významnosti 0,0031.

Čeští motocyklisté považují za větší problém než taiwanští motocyklisté nedání přednosti ze strany ostatních řidičů. Taiwanští motocyklisté naopak považují za větší riziko vlastní agresivní jízdní styl a nedostatek řidičských zkušeností a dovedností (více v Tabulce 1).

Taiwanští motocyklisté věří svým řidičským schopnostem více než čeští motocyklisté. 
Čeští motocyklisté se ale více než taiwanští snaží řidičské dovednosti využívat. Taiwanští motocyklisté si více než čeští myslí, že jsou více jiným řidičům hostilní. Taiwanští motocyklisté si častěji než čeští myslí také to, že častěji předjíždějí vozidla zprava (více v Tabulce 2).

Tabulka 1. Odpovědi na otázku „Ohodnot'te prosim, jak vnímáte závažnost následujících rizik z pohledu motocyklistì “

\begin{tabular}{|c|c|c|c|c|}
\hline & $\begin{array}{l}\text { Průmĕr } \\
\text { TW }\end{array}$ & $\begin{array}{l}\text { Průměr } \\
\mathrm{CZ}\end{array}$ & $\begin{array}{c}\text { Mann- } \\
\text { Whitney U }\end{array}$ & $\mathrm{p}$ \\
\hline Nepozornost jiného řidiče & 4,42 & 4,59 & 3700 & 0,4184 \\
\hline Agresivní chování ze strany ostatních řidičů & 4,46 & 4,39 & 3069,5 & 0,1567 \\
\hline $\begin{array}{l}\begin{array}{l}\text { Nerespektování motocyklistů } \\
\text { ostatních řidičů }\end{array} \\
\text { ze strany }\end{array}$ & 4,28 & 4,22 & 3133 & 0,2496 \\
\hline Nedání přednosti v jízdě ze strany jiného řidiče & 4,30 & 4,77 & 4358 & $0,0005^{*}$ \\
\hline $\begin{array}{l}\text { Jízda pod vlivem alkoholu a drog u ostatních } \\
\text { účastníkủ silničního provozu }\end{array}$ & 4,58 & 4,62 & 3451 & 0,9195 \\
\hline Vlastní jízda pod vlivem alkoholu či drog & 4,60 & 4,76 & 3759,5 & 0,2203 \\
\hline Vlastní agresivní jízdní styl & 4,46 & 4,11 & 2442 & $0,0005^{*}$ \\
\hline Nedostatek řidičských dovedností & 4,42 & 3,94 & 2073 & $0,0001^{*}$ \\
\hline $\begin{array}{l}\text { Nedostatek vlastní řidičské zkušenosti (najeté } \\
\mathrm{km} \text { ) }\end{array}$ & 3,93 & 3,49 & 2491,5 & $0,0017^{*}$ \\
\hline Vlastní nepozornost & 4,42 & 4,57 & 3599 & 0,6605 \\
\hline
\end{tabular}

Poznámka. ${ }^{*} \mathrm{p}<0,0031$.

Tabulka 2. Odpovědi na otázku „Označte, do jaké míry souhlasíte s následujícími výroky“

\begin{tabular}{|c|c|c|c|c|}
\hline & $\begin{array}{l}\text { Průměr } \\
\text { TW }\end{array}$ & $\begin{array}{l}\text { Průměr } \\
\mathrm{CZ}\end{array}$ & $\begin{array}{l}\text { Mann- } \\
\text { Whitney } \\
\text { U }\end{array}$ & $\mathrm{p}$ \\
\hline Faktor 1 - důvěra ve vlastní řidičské schopnosti & 13,54 & 10,36 & 1448,5 & $0,0001^{*}$ \\
\hline Faktor 2 - ochota riskovat & 8,53 & 7,77 & 2954 & 0,1017 \\
\hline Faktor 3 - využívání řidičských dovedností & 9,35 & 10,98 & 4561 & $0,0008^{*}$ \\
\hline Faktor 4 - hostilita vůči ostatním řidičům & 8,56 & 7,09 & 1730,5 & $0,0001^{*}$ \\
\hline I když spěchám, nemá to vliv na styl mé jízdy. & 2,58 & 2,35 & 2845,5 & 0,0381 \\
\hline Předjedu vozidlo zprava, když je na to dostatek místa. & 2,40 & 1,47 & 1409,5 & $0,0001^{*}$ \\
\hline
\end{tabular}

Poznámka. ${ }^{*} \mathrm{p}<0,0031$.

\section{Diskuse}

V první části dotazníku považovali čeští řidiči více než taiwanští za problematické pro bezpečnost nedání přednosti ze strany jiného řidiče, taiwanští naopak více než čeští nedostatky vlastní jízdy. Atribuce problémů spojených s bezpečností na druhé lidi místo na sebe může být 
zapřičiněna kulturními rozdíly. Lidé ve východní Asii mají menší tendenci atribuovat vinu ostatním oproti sobě samému než lidé na Západě (Heine, 2003).

Taiwanští řidiči mají pocit, že jejich řidičské schopnosti jsou lepší než je tomu u řidičů českých, a myslí si, že se při jízdě častěji rozčílí kvůli jiným řidičům. Zdá se tedy, že pro taiwanské řidiče je vlastní jízdní styl důležitější jak z hlediska atribuce nebezpečí, tak z pozitivního hlediska, tj. na ostatní řidiče berou při uvažování o jízdě a dopravních situacích menší zřetel než na sebe. Čeští řidiči v porovnání s jinými evropskými zeměmi častěji souhlasí s tím, že důvodem proč jezdí na motocyklu je svoboda (91\%) a pocit z jízdy $(83 \%$, Cestac \& Delhomme, 2012:190). Oproti jiným evropským zemím je také v ČR velké procentuální zastoupení sportovních motorek (s. 144). Je tedy možné, že tato větší sebejistota taiwanských řidičů je způsobena tím, že na Taiwanu jsou jednostopá motorová vozidla hlavním způsobem individuální dopravy, kdežto v ČR jde hlavně o rekreační aktivitu. S většími zkušenostmi tak může přijít i větší sebejistota. S možnými většími zkušenostmi taiwanských motocyklistů se může pojit i to, že méně než čeští motocyklisté zkoušejí své řidičské dovednosti např. při projíždění mezi kolonou vozidel.

Limitem výzkumu je výběr vzorku v ČR i na Taiwanu. V ČR šlo o účastníky kurzu, kdežto na Taiwanu o studenty a členy motorkářských skupin na Facebooku, zjištěné rozdíly tedy mohou být způsobeny odlišnými vzorky v obou kulturách. Rovněž jsme použili dotazník vytvořený ad hoc pro účastníky kurzů pro motocyklisty, který nebyl nijak standardizován.

\section{Závěr}

Prezentovaný výzkum může mít praktický význam pro instruktáž řidičů z obou zemí v prrípadě, že se rozhodnou ř́ídit motocykl nebo skútr v druhé zemi. Evropští řidiči motocyklů považují předjíždění zprava za vysoce rizikové chování (Cestac \& Delhomme, 2012:184). Ti, kteří za sebou mají dopravní nehodu, jej považují za méně rizikové než ti, kteří nehodu nezažili (s. 224), je tedy možné se domnívat, že nehodovost souvisí s podceněním rizika předjiždění zprava. Vzhledem k většímu souhlasu Taiwanců s tím, že předjíždějí zprava, je vhodné je předtím, než začnou řídit $\mathrm{v}$ ČR, upozornit na správný způsob předjiždění. Zatímco taiwanští řidiči automobilů mohou být na tento způsob předjíždění ze strany motocyklů zvyklí, u českých řidičů tomu tak být nemusí.

\section{Literatura}

Aupetit, S., Gallier, V., Riff, J., Espié, S., \& Delgehier, F. (2016). Naturalistic study of the risky situations faced by novice riders. Ergonomics, 59, 1109-1120. http://doi.org/10.1080/00140139.2015.1120887

Cestac, J., \& Delhomme, P. (eds., 2012). European road users' risk perception and mobility. The SARTRE 4 survey. Francie, SARTRE 4.

Chen, P.-L., Chen, Y.-Ch., \& Pai, Ch.-W. (2018). Motorcyclist Is the Right-of-Way Violator: A Population-Based Study of Motorcycle Right-of-Way Crash in Taiwan. Journal of Advanced Transportation, article no. 9543787. http://doi.org/10.1155/2018/9543787 
Chen, P.-L., \& Pai, Ch.-W. (2019). Evaluation of injuries sustained by motorcyclists in approach-turn crashes in Taiwan. Accident Analysis and Prevention, 124, 33-39. http://doi.org/10.1016/j.aap.2018.12.015

Creaser, J.I., Ward, N.J., Rakauskas, M.E., Shankwitz, C., \& Boer, E.R. (2009). Effects of alcohol impairment on motorcycle riding skills. Accident Analysis and Prevention, 41, 906-913. http://doi.org/10.1016/j.aap.2009.04.007

Crundall, E., Stedmon, A.W., Saikayasit, R., \& Crundall, D. (2013). A simulator study investigating how motorcyclists approach side-road hazards. Accident Analysis and Prevention, 51, 42-50. http://doi.org/10.1016/j.aap.2012.10.017

Heine, S.J. (2003). Making sense of East Asian self-enhancement. Journal of Cross-Cultural Psychology, 34, 596-602. http://doi.org/10.1177/0022022103256481

Huth, V., Füssl, E., \& Risser, R. (2014). Motorcycle riders' perceptions, attitudes and strategies: Findings from a focus group study. Transportation Research Part F, 25, 74-85. http://doi.org/10.1016/j.trf.2014.05.004

Jevtić, V., Vujanić, M., Lipovac, K., Jovanović, D., \& Stanojević, P. (2012). The influence of motives on risky behavior in traffic: Comparison between motorcyclists and passenger car drivers. Scientific Research and Essays, 7, 1134-1140. http://doi.org/10.5897/SRE11.1004

Lin, M.-R., Chang, S.-H., Pai, L., \& Keyl, P.M. (2003). A longitudinal study of risk factors for motorcycle crashes among junior college students in Taiwan. Accident Analysis and Prevention, 35, 243-252. http://doi.org/10.1016/S0001-4575(02)00002-7

Musselwhite, Ch.B.A., Avineri, E., Susilo, Y.O., \& Bhattachary, D. (2012). Public attitudes towards motorcyclists' safety: A qualitative study from the United Kingdom. Accident Analysis and Prevention, 49, 105-113. http://doi.org/10.1016/j.aap.2011.06.005

Özkan, T., Lajunen, T., Dogruyol, B., Yildirim, Z., \& Coymak, A. (2012). Motorcycle accidents, rider behaviour, and psychological models. Accident Analysis and Prevention, 49, 124-132. http://doi.org/10.1016/j.aap.2011.03.009

Pai, Ch.-W. (2011). Motorcycle right-of-way accidents - A literature review. Accident Analysis and Prevention, 43, 971-982. http://doi.org/10.1016/j.aap.2010.11.024

Rowden, P., Watson, B., Haworth, N., Lennon, A., Shaw, L., \& Blackman, R. (2016). Motorcycle riders' self-reported aggression when riding compared with car driving. Transportation Research Part F, 36, 92-103. http://doi.org/10.1016/j.trf.2015.11.006

Shahar, A., Clarke, D., \& Crundall, D. (2011). Applying the motorcyclist's perspective to improve car drivers' attitudes towards motorcyclists. Accident Analysis and Prevention, 43, 1743-1750. http://doi.org/10.1016/j.aap.2011.04.005

Vidotto, G., Bastianelli, A., Spoto, A., \& Sergeys, F. (2011). Enhancing hazard avoidance in teen-novice riders. Accident Analysis and Prevention, 43, 247-252.

http://doi.org/10.1016/j.aap.2010.08.017 


\section{Korespondující autor}

Mgr. et Mgr. Václav Linkov, Ph.D.

Centrum dopravního výzkumu, v.v.i.

Líšeňská 33a, 63600 Brno, Czech Republic

linkov@email.cz

Grantová podpora: Tento prŕíspěvek byl vytvořen za finanční podpory Ministerstva školství, mládeže a tělovýchovy v rámci programu Národní program udržitelnosti I, projektu Dopravní VaV centrum (LO1610) na výzkumné infrastruktuře pořízené z Operačního programu Výzkum a vývoj pro inovace (CZ.1.05/2.1.00/03.0064). 


\title{
The psychometric characteristics of the Hexaco-100 questionnaire used in the selection and non-selection situation
}

\section{Psychometrické charakteristiky dotazníka Hexaco-100 použitého vo výberovej a nevýberovej situácii}

\author{
Elena Lisá ${ }^{1}$, Mojmír Kališ \\ ${ }^{1}$ Fakulta psychológie, Paneurópska vysoká škola. Slovensko \\ ${ }^{2}$ Asociácia psychológov práce a organizácie Slovenska, Slovensko
}

\begin{abstract}
Objective. To compare some psychometric characteristics of the Hexaco-100 questionnaire by K. Lee and M. C. Ashton used in the selection situation and for comparison in the non-selective situation.

Method. The sample of candidates in the selection situation $(N=173)$ and the non-selection hospital staff $(N=63)$.

Results. Applicants in the selection scored higher in the dimensions of extraversion, conscientiousness and lower in the emotionality. They achieved lower Cronbach a scores in emotionality and conscientiousness. Overall, internal consistency of both samples was lower than Cronbach $\alpha$ in the foreign comparison samples. Cronbach $\alpha$ for Altruism was very low.

Conclusions. In the selection situation, we recommend except the Hexaco-100 to check the conscientiousness and emotional stability by another method; interpretation of altruism is not recommended; data in the honesty-humility factor are applicable for selection situation. For the next research, we recommend verifying the internal consistency and factor structure of the Slovak translation. The benefit of the study lies in real field data.
\end{abstract}

Limitations. The limits of the research study are in the difference between selection and nonselection sample.

Keywords. Hexaco-100; IM; selection situation

https://doi.org/10.5817/CZ.MUNI.P210-9488-2019-15 


\begin{abstract}
Abstrakt
Ciel'. V príspevku rozoberáme niektoré psychometrické vlastnosti dotazníka Hexaco-100 autorov K. Lee a M. C. Ashtona použitého v situácii výberu a pre porovnanie v nevýberovej situácii.

Metóda. V štúdii analyzujeme súbor uchádzačov z výberovej situácie $(N=173)$ a nevýberovú vzorku zamestnancov nemocnice $(N=63)$.

Výsledky. Uchádzači vo výbere skórovali vyššie v dimenziách extraverzia, svedomitost’ a nižšie vo faktore emocionalita. Dosiahli nižšie skóre Cronbach a vdimenziách emocionalita a svedomitost'. Celkovo sú hodnoty vnútornej konzistencie nižšie ako vzahraničných porovnávacích súboroch. Vnútorná konzistencia faktora altruizmus bola velmi nízka.
\end{abstract}

Závery. Vo výberovej situácii odporúčame overit' svedomitost' a emocionálnu stabilitu aj inou metódou ako je Hexaco-100; interpretáciu výsledkov pre faktor altruizmus neodporúčame; údaje vo faktore poctivost'-pokora sú použitelné pre výber. V d’alšom výskume odporúčame overit' vnútornú konzistenciu a faktorové sýtenie dotaznika HEXACO v slovenskom preklade. Prínos štúdie spočíva v reálnych dátach z terénu.

Limity výskumnej štúdie spočívajú v odlišnosti vzorky výberovej a nevýberovej.

Kl’účové slová. Hexaco-100; IM; výberová situácia

\title{
Úvod
}

Dotazníkom Hexaco sa v psychodiagnostike osobnosti začína na začiatku tohto storočia písat' nová kapitola faktorových modelov osobnosti založených na lexikálnej analýze. Šest'faktorový model je schopný zmerat' prítomnost' antisociálnych čŕt osobnosti (Visser, et. al., 2016). Táto skutočnost' bola zistená na základe výsledkov mnohých empirických štúdií (Hodson, Book, Visser, Volk, Ashton, Lee, 2018; Djeriouat, Trémolière, 2014; Aghababaei, Mohammadtabar, Saffarinia, 2014; Lee, Ashton, Wiltshire, Bourdage, Visser, Gallucci, 2013; Gaughan, Miller, Lynam, 2012; Bresin, Gordon, 2011; De Vries, Van Kampen, 2010), zvláśs' šiesty faktor poctivost'-pokora dopíňa štandardné pohl'ady na osobnost'. Z tohto dôvodu je Hexaco aj zaujímavou príležitost'ou pre psychodiagnostiku voblasti psychológie práce a organizácie - manažéri požadujú informácie o charakterových vlastnostiach uchádzačov o zamestnanie. Dotazník Hexaco je v posledných rokoch podrobovaný množstvu štúdií v rozdielnych kultúrach s ciel'om identifikovat' jeho psychometrické charakteristiky a d'alšie psychosociálne súvislosti (zoznam štúdií je uvedený na stránke http://www.hexaco.org/references). Špecifické použitie Hexaca v situácii výberu bolo skúmané najmä v súvislosti $\mathrm{s}$ impression managment (IM) pri výberových rozhovoroch (Roulin, Bourdage, 2017; Bourdage, Wiltshire, Lee, 2015; Buehl, Melchers, 2017). Výberová situácia je špecifická tým, že respondenti môžu mat' tendenciu falšovat' výpovede, aby dosiahli lepšie výsledky. Metaanalýza ukázala, že falošné odpovede pri psychometrickom testovaní vo výberovej situácii majú za následok vyššie hodnoty priemerného skóre, nižšie hodnoty štandardných odchýlok a nižšie hodnoty vnútornej konzistencie (Salgado, 2016). Aj Cattell a Shuerger (2003) upozorňujú na skresl’ujúce vplyvy výberovej situácie pôsobiace na výpovede 
o sebe. Validitu posudzovania osobnostných vlastností vo vzt'ahu k rozhodovaniu o prijatí tak znižuje prirodzený sklon l’udí posudzovat' sa v súlade $\mathrm{s}$ ich predstavou o vhodnom type osobnosti pre prácu. Levashina a Campion (2007) rozlišujú úprimný a klamlivý IM. Uchádzači s taktikou úprimného IM sa snažia vytvorit’ zdanie kompetencie, zvýrazňujú pozitívnu pravdu o minulých skúsenostiach a podobnosti s organizáciou. Naopak, klamlivý IM je typický tým, že uchádzači uvádzajú nepravdivé informácie o svojich skúsenostiach a kompetenciách. Podl'a výsledkov Roulin, Bourdage (2017) uchádzači s taktikou úprimný IM skórujú vyššie v extraverzii a jadrovom sebahodnotení. Uchádzači s taktikou klamlivý IM majú menej skúseností, skórujú nižšie v poctivosti-pokore, svedomitosti, no vyššie v extraverzii a v dimenziách temnej triády.

V súlade s tvrdeniami niektorých autorov (Salgado, 2016) predpokladáme, že výskumný súbor uchádzačov o zamestnanie bude skórovat' vyššie v sledovaných premenných, s nižšími hodnotami štandardných odchýlok a nižšími hodnotami vnútornej konzistencie, než súbor zamestnancov.

\section{Metódy}

Použili sme 100 položkový dotazník Hexaco-PI-R (Lee, Ashton, 2018) zo stránky http://hexaco.org/ v slovenskom preklade. Dotazník bol experimentálne administrovaný 173 uchádzačom o zamestnanie (obchodné, manažérske a administratívne pozície) ako prvý v batérii výberových testov a dotazníkov. Skupinu uchádzačov o zamestnanie tvorilo 77 žien a 96 mužov v priemernom veku 32,46 (SD = 8,29). Vysokoškolské vzdelanie malo $90 \%$, úplné stredné vzdelanie $10 \%$ uchádzačov. Porovnávacia nevýberová skupina pozostávala zo 63 zdravotníckych pracovníkov (sestry, lekári, administratíva a manažment). Zamestnanci vypĺn̆ali dotazník na princípe dobrovol'nosti, výmenou za výsledky. Manažment organizácie k výsledkom nemal prístup. Výskumný súbor „,zdravotníci“ tvorilo 63 osôb, 11 mužov a 52 žien v priemernom veku 45 rokov, v rozmedzí od 22 do 72 rokov. Vysokoškolské vzdelanie ukončilo $44 \%$ a stredoškolské $56 \%$ zamestnancov.

\section{Výsledky}

V tabul'ke 1 uvádzame výsledky vnútornej konzistencie výskumného súboru a pre porovnanie aj údaje o vnútornej konzistencie $\mathrm{z}$ nevýberových výskumných súborov iných krajín (Lee, Ashton, 2018; Babarović, Šverko, 2013; Burtăverde, 2015). V súbore uchádzačov sa hodnoty Cronbach $\alpha$ pohybujú od 0,62 do 0,73 , v súbore zamestnancov od 0,65 do 0,81 . Porovnatel'né sú hodnoty Cronbach alfa pre škálu poctivost' pokora $(0,62$ vs. 0,65$)$, pričom mierne vyššia alfa je v súbore nevýberovom. Vo faktore emocionalita sú hodnoty vnútornej konzistencie vyššie v nevýberovom súbore $(0,73$ vs. 0,81$)$. Vo faktore extraverzia sú hodnoty vnútornej konzistencie rovnaké v oboch výskumných súboroch $(0,72$ vs. 0,72$)$. Vo faktore prívetivost' bola nameraná vyššia hodnota vnútornej konzistencie v súbore nevýberovom $(0,67$ vs. 0,70$)$, tak isto vo faktoroch svedomitost' $(0,65$ vs. 0,78$)$, otvorenost' ku skúsenosti $(0,71$ vs. $0,72)$ a altruizmus $(0,16$ vs. 0,49$)$. Celkovo sa hodnoty Cronbach alfa odlišovali v oboch výskumných súboroch $\mathrm{v}$ rozpätí od $0 \mathrm{v}$ prípade extraverzie do $0,13 \mathrm{v}$ prípade 
Tabul'ka 1. Vnútorná konzistencia výsledkov

\begin{tabular}{|c|c|c|c|c|c|}
\hline Hexaco škály & 1 & 2 & 3 & 4 & 5 \\
\hline I. Čestnost' a pokora & 0,62 & 0,65 & 0,89 & 0,83 & 0,74 \\
\hline Úprimnost' & 0,54 & 0,37 & 0,78 & & \\
\hline Férovost' & 0,58 & 0,63 & 0,83 & & \\
\hline Nechamtivost' & 0,64 & 0,74 & 0,83 & & \\
\hline Skromnost' & 0,44 & 0,21 & 0,79 & & \\
\hline II. Emocionalita & 0,73 & 0,81 & 0,84 & 0,78 & 0,83 \\
\hline Bojazlivost' & 0,53 & 0,56 & 0,78 & & \\
\hline Úzkost' & 0,31 & 0,57 & 0,83 & & \\
\hline Závislost' & 0,62 & 0,72 & 0,83 & & \\
\hline Precitlivenost' & 0,57 & 0,65 & 0,79 & & \\
\hline III. Extraverzia & 0,72 & 0,72 & 0,86 & 0,82 & 0,87 \\
\hline Sociálne sebavedomie & 0,53 & 0,59 & 0,70 & & \\
\hline Sociálna odvaha & 0,24 & 0,30 & 0,72 & & \\
\hline Sociabilita & 0,41 & 0,47 & 0,77 & & \\
\hline Živost' & 0,64 & 0,61 & 0,78 & & \\
\hline IV. Prívetivost' & 0,67 & 0,70 & 0,86 & 0,85 & 0,82 \\
\hline Odpustenie & 0,49 & 0,53 & 0,78 & & \\
\hline Miernost', plachost' & 0,48 & 0,66 & 0,72 & & \\
\hline Flexibilita & 0,37 & 0,47 & 0,64 & & \\
\hline 'Trpezlivost' & 0,55 & 0,63 & 0,80 & & \\
\hline V. Svedomitost' & 0,65 & 0,78 & 0,82 & 0,83 & 0,85 \\
\hline Organizovanost' & 0,62 & 0,68 & 0,73 & & \\
\hline Pracovitost' & 0,45 & 0,70 & 0,71 & & \\
\hline Perfekcionizmus & 0,45 & 0,55 & 0,69 & & \\
\hline Opatrnost' & 0,47 & 0,55 & 0,70 & & \\
\hline VI.Otvorenost' k skúsenosti & 0,71 & 0,72 & 0,82 & 0,83 & 0,61 \\
\hline Estetická orientácia & 0,62 & 0,69 & 0,65 & & \\
\hline Zvedavost' & 0,66 & 0,59 & 0,70 & & \\
\hline Inovatívnost' & 0,37 & 0,45 & 0,73 & & \\
\hline Nekonvenčnost' & 0,17 & 0,00 & 0,79 & & \\
\hline VII. Altruizmus & 0,16 & 0,49 & 0,57 & & \\
\hline
\end{tabular}

Vysvetlivky. 1 = uchádzači o zamestnanie; 2 = zdravotnícki pracovníci; 3 = USA (Lee, Ashton, 2018); 4 $=$ Chorvátsko (Babarović, Šverko, 2013); 5 = Rumunsko (Burtăverde, 2015)

svedomitosti. V šiestich vel'kých faktoroch je hodnota Cronbach alfa spornej až dobrej úrovni (Bailey, 2017), v rozmedzí od 0,6 po 0,81. Vel'mi nízky koeficient je však v prípade škály 
altruizmus, pričom je nižší v súbore uchádzačov o prácu. Analýza vnútornej konzistencie navyše preukázala nižšie hodnoty v súboroch slovenských respondentov v porovnaní s údajmi z USA, Chorvátska a Rumunska.

V analýze sme d’alej pokračovali testovaním rozdielov medzi výskumným súborom výberovej a nevýberovej vzorky. Pretože sa hodnoty Cronbach alfa v subškálach pohybovali často na slabej úrovni, v d'alšej analýze budeme interpretovat' len rozdiely v šiestich faktoroch dotazníka Hexaco-100. Hodnoty priemerov, štandardných odchýlok ako aj hodnoty štatistickej a vecnej významnosti rozdielov uvádzame v tabul'ke 2. Budeme opisovat' len faktorové rozdiely vysoko štatisticky $(\mathrm{p} \leq 0,001)$ a silne vecne významné (Cohenovo $\mathrm{d} \geq 0,8)$. V tomto zmysle sa nepreukázali rozdiely vo faktore poctivost'-pokora, prívetivost' a otvorenost'. Vo faktore emocionalita prejavovali uchádzači o zamestnanie nižšie skóre a hodnotili sa tak, že sa menej obávajú cestovat' za zlého počasia a fyzického nebezpečenstva, odlúčenia na dlhšie od blízkej osoby, sú menej ovplyvnitel'ní negatívnymi alebo sentimentálnymi emóciami iných, menej prepadajú panike, prežívajú nižšiu úzkost'ou pred dôležitými rozhodnutiami. V rámci faktora extraverzia dosiahli uchádzači o zamestnanie vyššie skóre a hodnotili sa ako spokojnejší sami so sebou, nevyhýbajúci sa nezáväzným debatám o počasí s inými l'ud'mi, ako skoro stále plní energie, oblúbenejší u iných, obl’ubujúci množstvo l’udí okolo seba, s ktorými sa dá rozprávat', veselší, optimistickejší, dynamickejší, schopnejší a hodnotnejší. Vo svedomitosti sa hodnotili uchádzači vyššie, čiže ako osoby, ktoré si kladú ambicióznejšie ciele, sú snaživejší a nevzdávajú sa pri dosahovaní ciel’ov, majú vyššiu pracovnú morálku a sú ochotnejší vynakladat' vysoké pracovné úsilie, zároveň ako starostlivejšie zvažujúci svoje možnosti a pracovné plány, s vyššou tendenciou ovládat' svoje impulzy.

Porovnanie štandardných odchýlok preukázalo rozdiely medzi uchádzačmi o prácu a zamestnancami v rozpätí od $-0,01$ do 0,07 . Ked’že sa tieto hodnoty pohybujú okolo nuly, môžeme povedat', že rozdiely v štandardných odchýlkach neevidujeme.

\section{Diskusia}

Rozdiely medzi skupinou uchádzačov o zamestnanie a zamestnancami nemocnice ukazujú, že celkovo sa uchádzači hodnotili ako emočne stabilnejší, extravertovanejší a svedomitejší. Od nevýberovej vzorky zamestnancov sa nelíšili vo faktore poctivost'-pokora, prívetivost' a otvorenost'. Za predpokladu, že sa uchádzači o prácu vykresl’ujú v lepšom svetle, môžeme povedat', že uchádzači sa prikrášlovali najmä v postoji k práci, v profesionálnom odstupe od emócií, v usilovnosti, rozvážnosti a v pripravenosti k sociálnym kontaktom. Pôsobili ako za každých okolností spol'ahliví pracovníci a profesionáli. Neštylizovali sa v dimenziách kvality sociálnych vzt’ahov v zmysle poctivosti-pokory a prívetivosti. Rozdiely medzi výberovou a nevýberovou vzorkou neboli významné vo faktore poctivost'-pokora, no naopak, boli významné v dimenzii extraverzia a svedomitost', preto sa možno domnievat', že uchádzači o výber prejavovali skôr tzv. úprimného IM (Roulin, Bourdage, 2017). Nepotvrdil sa predpoklad, že uchádzači skórujú vyššie vo všetkých premenných (Salgado, 2016). 
Tabul'ka 2. Opisné štatistiky a rozdiely v súbore uchádzačov o zamestnanie a zdravotníckych pracovníkov

\begin{tabular}{|c|c|c|c|c|c|c|c|}
\hline & Group & Mean & SD & SE & $\mathbf{t}$ & $\mathbf{p}$ & Cohen's d \\
\hline \multirow{2}{*}{ Poctivost'-pokora } & 1 & 3.766 & 0.399 & 0.030 & \multirow{2}{*}{1.320} & \multirow{2}{*}{0.188} & \multirow{2}{*}{0.194} \\
\hline & 2 & 3.689 & 0.385 & 0.048 & & & \\
\hline \multirow{2}{*}{ Emocionalita } & 1 & 2.782 & 0.449 & 0.034 & \multirow{2}{*}{-7.674} & \multirow{2}{*}{$<.001$} & \multirow{2}{*}{-1.129} \\
\hline & 2 & 3.307 & 0.503 & 0.063 & & & \\
\hline \multirow{2}{*}{ Extraverzia } & 1 & 3.893 & 0.352 & 0.027 & \multirow{2}{*}{10.252} & \multirow{2}{*}{$<.001$} & \multirow{2}{*}{1.509} \\
\hline & 2 & 3.348 & 0.389 & 0.049 & & & \\
\hline \multirow{2}{*}{ Prívetivost' } & 1 & 3.295 & 0.395 & 0.030 & \multirow{2}{*}{3.173} & \multirow{2}{*}{0.002} & \multirow{2}{*}{0.467} \\
\hline & 2 & 3.103 & 0.455 & 0.057 & & & \\
\hline \multirow{2}{*}{ Svedomitost' } & 1 & 3.995 & 0.390 & 0.030 & \multirow{2}{*}{9.307} & \multirow{2}{*}{$<.001$} & \multirow{2}{*}{1.370} \\
\hline & 2 & 3.432 & 0.464 & 0.058 & & & \\
\hline \multirow{2}{*}{ Otvorenost' ku skúsenosti } & 1 & 3.472 & 0.454 & 0.035 & \multirow{2}{*}{4.807} & \multirow{2}{*}{$<.001$} & \multirow{2}{*}{0.707} \\
\hline & 2 & 3.150 & 0.459 & 0.058 & & & \\
\hline
\end{tabular}

Vysvetlivky. 1 = uchádzači o zamestnanie; 2 = zamestnanci

Tieto výsledky mohli byt' ovplyvnené nerovnakým zložením výskumnej vzorky. Je pravdepodobné, že zdravotnícki pracovníci by mohli skórovat' v škále poctivost'-pokora vyššie, než je priemer dospelej populácie, zvlášt' v porovnaní so zamestnancami na primárne obchodníckych a manažérskych pozíciách. V takom prípade, aj keby sa uchádzači o zamestnanie štylizovali do poctivejšej podoby, tento rozdiel by kvôli prirodzene vyššej úrovni v prípade zdravotníckych zamestnancov zanikol. Takisto vyššie skóre extraverzie mohlo byt' spôsobené pracovným zameraním výskumného súboru uchádzačov o prácu za predpokladu, že uchádzači na obchodnícke a manažérske pozície sú prirodzene extravertovanejší. Tieto interpretácie by však bolo treba overit' na výskumných súboroch zamestnancov z iného profesionálneho prostredia, poprípade na reprezentatívnejších výskumných súboroch, alebo ideálne na rovnakom výskumnom súbore l'udí v oboch situáciách (výberovej aj nevýberovej). Zaujímavým výsledkom je vyššie skóre emočnej lability v prípade zdravotníckych zamestnancov, než v prípade uchádzačov o prácu. Zdravotnícke prostredie vyžaduje vysokú úroveň emočnej stability, preto sa možno domnievat', že v prípade uchádzačov o zamestnanie išlo naozaj o štylizovanie sa do ideálneho obrazu pokojného profesionála. Podobne by sme interpretovali vyššie skóre svedomitosti u uchádzačov o prácu v porovnaní so zdravotníckymi zamestnancami.

Rozdiely v štandardných odchýlkach oboch súborov sa pohybovali okolo hodnoty nula, čo vyvracia predpoklad, že uchádzači o prácu dosiahnu klamlivými výpoved’ami nižšie hodnoty štandardných odchýlok (Salgado, 2016). 
Takisto sa nepotvrdil predpoklad, že hodnoty Cronbach alfa budú nižšie vo výberovom súbore uchádzačov o prácu (Salgado, 2016). Uchádzači o prácu však dosiahli nižšiu vnútornú konzistenciu v porovnaní so zamestnancami najmä vo faktoroch emocionalita a svedomitost'. Za predpokladu, že vo výberovom konaní sa človek vykresl'uje v lepšom svetle a podáva klamlivé výpovede, vyššie hodnoty stability a svedomitosti, zároveň s nižšími hodnotami vnútornej konzistencie by mohli hovorit' o prilepšovaní sa najmä v dimenziách svedomitost' a emocionalita. Lepšie priemerné skóre emocionality a svedomitosti, ako aj nižšie hodnoty Cronbach alfa v týchto škálach potvrdzujú teoretický model Salgada (2016) o klamlivých výpovediach. Celkovo však boli v oboch výskumných súboroch zo Slovenska dosiahnuté nižšie hodnoty Cronbach alfa, než v zahraničných štúdiách (Lee, Ashton, 2018; Babarović, Šverko, 2013; Burtăverde, 2015). Dôvody týchto nízkych hodnôt môžu spočívat' v reálnej vzorke dospelých pracujúcich $\mathrm{z}$ terénu, $\mathrm{v}$ protiklade so zvyčajnými výskumnými vzorkami tvorenými študentmi. No ked’že dotazník Hexaco-100 nie je psychometricky overený v slovenskom jazyku, je t’ažké usudzovat' na to, aké hodnoty sú v slovenskom preklade normálne.

Na základe dosiahnutých výsledkov sme formulovali odporúčania do praxe výberových konaní, ako aj odporúčania pre d’alší výskum.

\section{Odporúčania do praxe pre výberové konania}

Ak chceme overit' uchádzačovu úroveň svedomitosti a emocionálnej stability, je vhodné tieto vlastnosti overit' aj inou doplnkovou metódou a nespoliehat' sa len na výsledky dotazníka Hexaco-100.

Kvôli nízkym hodnotám vnútornej konzistencie neodporúčame v praxi vyhodnocovat' a interpretovat' výsledky pre škálu altruizmus.

Odporúčame, v súlade s výsledkami aj iných výskumných štúdií (Roulin, Bourdage, 2017; Bourdage, Wiltshire, Lee, 2015; Buehl, Melchers, 2017) vyhodnocovat' a interpretovat' výsledky pre faktor poctivost'-pokora, ako prediktora etického a morálneho správania. Tento faktor poskytuje relatívne spol'ahlivé informácie pre výber v kontexte, že vyberáme vhodného uchádzača/ov spomedzi viacerých kandidátov.

Z dôvodu sporných hodnôt vnútornej konzistencie (Cronbach alfa medzi 06 až 0,7 ) neodporúčame používat' faktor poctivost'-pokora pre individuálne hodnotenie pracovníkov.

\section{Odporúčania pre d'alší výskum}

V d'alšom výskume považujeme za potrebné overit' vnútornú konzistenciu a faktorové sýtenie dotazníka Hexaco-100 v slovenskom preklade na početnejšej alebo reprezentatívnej vzorke respondentov. Štandardizácia dotazníka Hexaco 100 by mala prebehnút' nielen v bežnej populácii, ale aj v populácii v situácii výberu. Pretože ponúka možnost' predikovat' etické a morálne správanie pracovníkov, môže byt' dotazník Hexaco-100 pre zamestnávatel'ov vel'mi atraktívny. Na potrebu osobitnej štandardizácie pre situácie výberu upozorňujú aj Sedláková a Knapová (2017) v súvislosti s dotazníkom LMI. 
Takisto odporúčame, v zhode so Záškodnou a Dostálom (2016) revidovat' preklad jednotlivých položiek. Na Slovensku napríklad nie je bežné študovat' encyklopédie v takom meradle, ako v USA. Nie je bežné, že by Vám na dvere zaklopal predajca encyklopédií. Otázka na čítanie encyklopédií nemusí u slovenského respondenta rezonovat' rovnako ako u respondenta zo severoamerického kontinentu.

Pretože podl'a nás hlavný limit štúdie spočíva v rozličnom zložení porovnávacích súborov, do budúceho výskumu odporúčame realizovat' analýzu na vzorkách rovnocenných v základných demografických premenných, akými sú vek, pohlavie, vzdelanie, prípadne pracovné zaradenie. Ideálne by bolo samozrejme realizovat' porovnanie na rovnakom výberovom súbore, raz v situácii výberu a druhý raz už v situácii na pozícii zamestnanca.

Za prínos štúdie považujeme dáta získané dotazníkom Hexaco-100 v reálnych podmienkach výberového konania a zamestnaneckého pomeru. Domnievame sa, že takto získané výsledky sa môžu odlišovat' od výsledkov získaných na vzorkách vysokoškolských študentov. Za d'alší prínos považujeme zistenie, že škála poctivost'-pokora sa javí ako intaktná v kontexte výberovej situácie. Pre závažnejšie závery je však potrebné metódu Hexaco-100 v slovenskom preklade ešte bližšie preskúmat'.

\section{Literatúra}

Aghababaei, N., Mohammadtabar, S., Saffarinia, M. (2014). DirtyDozenvs. the H factor: Comparison of the Dark Triad and Honesty-Humility in prosociality, religiosity, and happiness. Personality and IndividualDifferences, 67, 6-10. http://doi.org/10.1016/j.paid.2014.03.026

Bailey, R. (2017). HR Applications of psychometrics. In: B. Cripps, Psychometric Testing: Critical Perspectives (pp. 87-111). Hoboken: Wiley. http://doi.org/10.1002/9781119183020.ch7

Babarović, T., Šverko, I. (2013). The Hexaco Personality Domains in The Croatian Sample. Journal for General Social Issues, 22(3), 397-411. http://doi.org/10.5559/di.22.3.01

Bourdage, J.S., Wiltshire, J., Lee, K. (2015). Personality and workplace impression management: Correlates and implications. Journal of Applied Psychology, 100(2), 537546. http://doi.org/10.1037/a0037942

Bresin, K., Gordon, K.H. (2011). Characterizing pathological narcissism in terms of the HEXACO model of personality. Journal of Psychopathology and Behavioral Assessment, 33, 228-235. http://doi.org/10.1007/s10862-010-9210-9

Buehl, A-K, Melchers, K.G. (2017). Individual Difference Variables and the Occurence and Effectiveness of Faking Behavior in Interviews. Frontiers in Psychology, 8, 686. http://doi.org/10.3389/fpsyg.2017.00686

Burtăverde, V. (2015) Psychometric Properties of The Hexaco Pi-R on a Romanian Sample. The Relationship with Work Outcomes and General Outcomes. Romanian Journal of Experimental Applied Psychology, 6(1), 31-58. 
Cattel, H.E.P., Schrueger, J.M. (2003). Essentials of 16 PF Assessment. John Wiley \& Sons.

De Vries, R.E., Van Kampen, D. (2010). The HEXACO and 5DPT models of personality: A comparison and their relationships with psychopathy, egoism, pretentiousness, immorality, and machiavellianism. Journal of Personality Disorders, 24, 244-257. http://doi.org/10.1521/pedi.2010.24.2.244

Djeriouat, H., Trémolière, B. (2014). The Dark Triad of personality and utilitari anmoral judgment: The mediating role of Honesty/Humility and Harm/Care. Personality and Individual Differences, 67, 11-16. http://doi.org/10.1016/j.paid.2013.12.026

Gaughan, E.T., Miller, J. D., Lynam, D. R. (2012). Examining the utility of general models of personality in the study of psychopathy: A comparison of the HEXACO-PI-R and NEO PIR. Journal of Personality Disorders, 26, 513-523. http://doi.org/10.1521/pedi.2012.26.4.513

Hodson, G., Book, A., Visser, B. A., Volk, A. A., Ashton, M. C., \&Lee, K. (2018). Is the dark triad common factor distinct from low honesty-humility? Journal of Research in Personality, 73, 123-129. http://doi.org/10.1016/j.jrp.2017.11.012

Lee, K., Ashton, M., C. (2018). Psychometric Properties of the HEXACO-100. Assessment, 25(5), 543-556. http://doi.org/10.1177/1073191116659134

Lee, K., Ashton, M. C., Wiltshire, J., Bourdage, J. S., Visser, B. A., Gallucci, A. (2013). Sex, power, and money: Prediction from the Dark Triad and Honesty-Humility. European Journal of Personality, 27, 169-184. http://doi.org/10.1002/per.1860

Levashina, J., Campion, M.A. (2007). Measuring faking in the employment interview: development and validation of an interview faking behaviour scale. Journal of Applied Psychology, 92, 1638-1656. http://doi.org/10.1037/0021-9010.92.6.1638

Roulin, N., Bourdage, J.S. (2017). Once an Impression Manager, Always an Impression Manager? Antecedents of Honest and Deceptive Impression Management Use and Variability across Multiple Job Interviews. Frontiers in Psychology, 8(29). http://doi.org/10.3389/fpsyg.2017.00029.

Salgado, J.F. (2016). A theoretical model of psychometric effects of faking on assessment procedures: Empirical findings and implications for personality psychology at work. International Journal of Selection and Assessment, 24, 209-228. http://doi.org/10.1111/ijsa.12142.

Sedláková, J., Knapová, L. (2017). Dotazník motivace k výkonu - Recenze metody. Testfórum, 8, 19-24. http://doi.org/10.5817/TF2017-8-132

Visser, B. A., Book, A. S., Volk, A. A. (2016). Is Hillary dishonest and Donald narcissistic? A HEXACO analysis of the presidential candidates' public personas. Personality and Individual Differencies, 106, 281-286. http://doi.org/10.1016/i.paid.2016.10.053

Záškodná T., Dostál D. (2016). Šestifaktorový model osobnosti a psychometrické vlastnosti revidovaného osobnostního inventáŕe HEXACO, Psychologie a její kontexty, 7(2), 31-42. 


\section{Korespondující autor}

doc. Mgr. Elena Lisá, PhD.

Faculty of Psychology, Pan-European University

Tomasikova 20, 82009 Bratislava, Slovakia

elena.lisa@paneurouni.com 


\title{
The reflection of transformational, pseudotransformational and laissez- faire leadership in employee engagement, trust and innovation (pilot phase - movie method)
}

\author{
Reflexia transformačného, pseudotransformačného a laissez-faire leadershipu v \\ angažovanosti, dôvere a inovácii zamestnancov (pilotná fáza - metóda filmu)
}

Jana Lišková ${ }^{1}$, Denisa Drabová ${ }^{1}$

${ }^{1}$ Comenius University in Bratislava, Slovakia

\begin{abstract}
Objectives. The aim of the paper is to present the pilot phase of the second part of the research on verifying the new leadership concept (transformational - TL, pseudotransformational -PTL and laissez-faire - LFL) in terms of employee engagement, trust and innovation.
\end{abstract}

Method. In a between-subject experimental design, categories of leadership were manipulated by the movie method (12 Angry Men). The role of the participants was to focus attention on selected characters (leaders) while watching the film and then respond to self-assessing scales (engagement, trust, innovation). The sample of the pilot study consisted of 36 students.

Results. The results were analysed by variance analysis (ANOVA) and showed statistically significant differences in engagement, trust and innovation depending on the type of leadership. Participants perceived the highest engagement, trust and innovation in the TL condition, the lowest in the condition with PTL.

Conclusions. The TL reiterated its positive effects on working attitudes and behaviour; on the other hand, PTL again appears to be the "worst" among the selected leadership styles. The LFL did not appear as negative in our research as it is described in the literature. We consider the pilot study to be a necessary step to carry out research on a target sample of employees.

Limits. The limit of research is undoubtedly the size of the sample, the use of self-assessing scales and the risk of the possible impact of the movie's character un / sympathy on the outcome.

Keywords. transformational leadership; pseudotransformational leadership; laissez-faire leadership; engagement; trust; innovation

https://doi.org/10.5817/CZ.MUNI.P210-9488-2019-16 


\begin{abstract}
Abstrakt
Ciele. Ciel'om príspevku je prezentovat' pilotnú fázu druhej časti výskumu overovania novej koncepcie leadershipu (transformačný - TL, pseudotransformačný - PTL a laissez-faire - LFL) $v$ súvislosti s angažovanostou, dôverou a inováciou zamestnancov.

Metóda. V medzisubjektovom experimentálnom dizajne boli kategórie leadershipu manipulované metódou filmu (12 Angry Men). Úlohou participantov bolo počas sledovania filmu zameriavat' pozornost' na vybrané postavy (leaderov) a následne odpovedat' na škály (angažovanost', dôvera, inovácia). Výberový súbor pilotnej štúdie tvorilo 36 študentov.

Výsledky. Výsledky boli analyzované prostredníctvom analýzy variancie (ANOVA) a preukázali štatisticky významné rozdiely v angažovanosti, dôvere aj inovácii v závislosti od leadershipu. Najvyššiu angažovanost', dôveru a inováciu vnímali participanti v pri TL, najnižšiu v pri PTL.

Závery. TL opätovne poukázal na svoje priaznivé účinky na pracovné postoje a správanie, na druhej strane PTL sa opät' javí ako najhorši spomedzi vybraných štýlov vedenia. LFL sa v našom výskume neprejavil tak negatívne, ako býva popisovaný v literatúre. Pilotný výskum považujeme za nevyhnutný krok potrebný pre uskutočnenie výskumu na cielovej vzorke zamestnancov.
\end{abstract}

Limity. Limitom výskumu je nepochybne vel'kost' vzorky, použitie sebaposudzujúcich škál i riziko možného vplyvu ne/sympatií filmových postáv na výsledok.

Kl’účové slová. transformačný leadership; pseudotransformačný leadeship; laissez-faire leadership; angažovanost'; dôvera; inovácia

\title{
Úvod
}

V problematike leadershipu existuje množstvo koncepcií a teórií. Transformačný leadership už patrí k „stáliciam“ vo výskume štýlov vedenia, avšak jeho protipól pseudotransformačný leadership, doteraz zostával skôr mimo focus vedeckej obce. Jeho implikácie na pracovné postoje (ako napr. angažovanost', dôvera, inovácia) sú len málo preskúmané a málo rezonujú ako v praxi, tak aj v teórii. Zámerom našej práca je preto doplnit’ túto medzeru a to najmä v kontexte pracovných postojov, ktorých výskum je často žiadaný najmä praxou - samotnými organizáciami (angažovanost' a dôvera, nakol'ko súvisia s výkonom, Kovjanic, Schuh \& Jonas, 2013; Kelloway, Turner, Barling, \& Loughlin, 2012; a inovácia, ktorá je kl'účom k rozvoju organizácie; Contreras, Espinosa, Dornberger, \& Acosta, 2017). V našej práci preto vychádzame z koncepcie Christie, Barlinga a Turnera (2011), ktorí rozlišujú medzi uvedenými typmi vedenia (transformačným (TL), pseudotransformačným (PTL) a laissez-faire (LFL) leadershipom) a zameriavame našu pozornost' na uvedené pracovné postoje a správanie. 


\section{Leadership}

Charakteristiky vybraných štýlov možno popísat' prostredníctvom 4 komponentov TL: idealizovaný vplyv, inšpirujúca motivácia, intelektuálna stimulácia, individuálny prístup.

Transformačný leader je vd'aka charizme pre ostatných vzorom, ide mu o kolektívne dobro (idealizovaný vplyv); podnecuje tímového ducha, motivuje a inšpiruje tým, že dodáva význam práci a poskytuje podriadeným výzvu (inšpirujúca motivácia), podporuje tvorivost', povzbudzuje kreativitu a inováciu preformulovaním úloh, novými prístupmi k doterajším problémom, nekritizuje iných myšlienky kvôli odlišnosti od svojich vlastných myšlienok (intelektuálna stimulácia); každému $\mathrm{z}$ tímu venuje zvláštnu pozornost', pôsobí ako kouč/mentor, akceptuje individuálne odlišnosti zamestnancov (individuálny prístup; Bass \& Riggio, 2006).

Pseudotransformačný leader zdôrazňuje domnelé hodnotové rozdielnosti „my“ vs. „oni“, pričom dobré hodnoty pripisujú sebe, tzn. „my“ (idealizovaný vplyv; Bass \& Steidlmeier, 1999); talent inšpirovat' druhých využíva k dosahovaniu vlastných ciel'ov prostredníctvom ich manipulovania (inšpirujúca motivácia); vedome usiluje proti nezávislým názorom podriadených, bráni tvorivému a kritickému mysleniu (intelektuálna stimulácia); rozvoj a podporu zamestnancov akceptuje a poskytuje dovtedy, dokedy z toho profituje (individuálny pristup; Christie, Barling \& Turner, 2011).

Laissez-faire leader sa nepokúša inšpirovat' $\mathrm{k}$ dosahovaniu výziev a ciel'ov (idealizovaný vplyv); ojedinele motivuje podriadených (inšpirujúca motivácia); podriadení od neho nedostávajú podporu pre rozvíjanie ich vlastných názorov a myslenia, ale LFL ani im v tom nebráni, teda nezasahuje do intelektuálneho napredovania (intelektuálna stimulácia); nezaujíma sa o rozvoj l’udí (individuálny prístup; Christie, Barling \& Turner, 2011).

\section{Angažovanost'}

Schaufeli, Bakker, a Salanova (2006) považujú angažovanost' za pozitívny na prácu sa vzt'ahujúci stav (nevzt'ahuje sa na žiadny konkrétny objekt/udalost'/správanie), ktorý je odrazom vnútornej motivácie. V ich koncepcii angažovanost' tvoria 3 faktory: energickost' (vysoký level energie a mentálnej odolnosti, ochota investovat' úsilie a vytrvat' napriek t’ažkostiam), nadšenie/oddanost' (entuziazmus, inšpirácia, silná identifikácia sa s prácou) a pohltenie (plná sústredenost' a ponorenost' do práce). Súvislost' medzi angažovanostou a pracovným výkonom už preukázalo niekol'ko autorov (napr. Kovjanic, Schuh \& Jonas, 2013), rovnako, ako bol preukázaný pozitívny vzt’ah medzi TL a týmto pracovným postojom (Lišková \& Tomašč́ková, 2019; Lee Whittington, \& Galpin, 2010). Vo výskume Liškovej a Tomašč́kovej (2019) bola angažovanost' najnižšia pri PTL, najvyššia pri TL, medzi LFL a PTL nebol rozdiel štatisticky významný. 


\section{Dôvera}

Dôvera je subjektívne očakávanie, presvedčenie alebo predpoklad, o pravdepodobnosti, že budúce konanie druhých l'udí bude mat' priaznivý vplyv na záujmy jednotlivca (Robinson, 1996). Vzt'ah medzi dôverou vo vedenie a vyšším pracovným výkonom, rovnako aj TL ako sprostredkovatel'om, bol podporený viacerými výskumnými zisteniami (Kelloway, Turner, Barling, \& Loughlin, 2012). Bol zistený negatívny vplyv PTL na dôverou (Christie, Barling, \& Turner, 2011). Tosunoglu a Ekmekci (2016) výskumne zistili, že zamestnanci pracujúci pod LFL majú zníženú dôveru v organizáciu. Vo výskume Liškovej a Tomaščíkovej (2019) participanti dôverovali LFL významne menej ako TL a významne viac ako PTL.

\section{Inovácia}

Inovácia je myšlienka, postup alebo vec, ktorú jednotlivec, organizácia , alebo iný celok (ktorý predstavuje príjemcu), vnímaná ako nová (Carreiro, \& Oliveira, 2019). Je rozhodujúca pre udržatel'nost', rozvoj a konkurencie schopnost' spoločností v súčasnosti (Contreras, Espinosa, Dornberger, \& Acosta, 2017). Medzi inovatívnym pracovným správaním a TL bol preukázaný priamy pozitívny vzt’ah (Contreras, Espinosa, Dornberger, \& Acosta, 2017). Literatúra naznačuje negatívne spojenie inovácie s LFL, ked’že napomáhanie inováciám predpokladá podporu pri odstraňovaní zaužívaných postupov (Ryan \& Tipu, 2013), čo je podl’a autorov v rozpore s LFL. V preštudovanej literatúre sme nenašli výskumné zistenia, ktoré by určovali aký je vzt'ah medzi inováciou a PTL. V pilotnom výskume Liškovej a Tomaščíkovej (2019), realizovanom metódou úryvkov, bola zistená najnižšia úroveň inovácie u PTL.

\section{Metódy}

\section{Ciel' výskumu a hypotézy}

Ciel'om výskumu je pilotné testovanie reflexie vybraných druhov leadershipu (TL, PTL, LFL) v rámci pracovných postojov (angažovanost', dôvera) a pracovného správania (inovácia).

H1: Predpokladáme štatisticky významný rozdiel v úrovni angažovanosti, dôvery a inovácie v závislosti od druhu leadershipu.

\section{Výskumný dizajn}

Hoci je v súčasnosti dostupných niekol'ko verzií dotazníka MLQ (Multifactor leadership Questionaire) zameraného na skúmanie TL, podl'a nám dostupnej literatúry, doposial' nebola vytvorená metóda, ktorá by umožňovala spol'ahlivo rozlišovat' medzi všetkými sledovanými druhmi vedenia (TL, PTL, LFL). Rozhodli sme sa preto inšpirovat' prácou Christie, Barlinga a Turnera (2011) a volíme experimentálny medzisubjektový dizajn. 


\section{Výskumné metódy - Leadership}

Na manipuláciu leadershipu sme zvolili metódu filmu³ . Okrem už vyššie spomínaného sme sa pre túto metódu rozhodli tiež v súlade s názorom Christie, Barlinga, a Turnera (2011), podl'a ktorých metóda filmu zvyšuje externú validitu použitím viac komplexného reprezentatívneho správania. Ako podnetový materiál bol použitý film 12 Angry Men (Donnely \& Friedkin, 1997) v českom dabingu. Dej filmu sa odohráva v jednej miestnosti, vybrané postavy sú v zábere približne rovnaké množstvo času ${ }^{4}$. Konkrétnejšie prejavy správania, na základe ktorých boli postavy (porotcovia) identifikovaní ako predstavitelia jednotlivých typov leadershipu uvádzajú vo svojej práci Christie, Barling a Turner (2011).Vhodnost' filmu aj efekt uvedených typov vedenia postáv na pracovné postoje (napr. dôvera) už boli preukázané (Lišková \& Rošková, 2017; Christie, Barling, Turner, 2011).

Kontrola manipulácie. Napriek vyššie uvedenému sme však považovali za nevyhnutné opätovne overit', či zvolené filmové postavy naozaj reprezentujú vybrané typy leadershipu. Pred realizáciou samotného pilotného výskumu bola teda vykonaná kontrola manipulácie.

Kontrola manipulácie - výskumný súbor. Kontrola manipulácie bola realizovaná na vzorke 57 participantov - 22 mužov a 35 žien $(\mathrm{M}=22,77$; $\mathrm{SD}=5,43)$. Výskumný súbor kontroly manipulácie bol tvorený 44 študentmi a 13 zamestnancami.

Kontrola manipulácie - výskumné metódy. Na vykonanie kontroly manipulácie sme použili film 12 Angry Men (Donnely \& Friedkin, 1997) a stručný opis TL, PTL, LFL validizovaný v práci Tomaščíkovej (2018) a Liškovej a Tomašćíkovej (2019). Úlohou participantov bolo prečítat' si definície TL, PTL, LFL, pri pozeraní filmu venovat' špeciálnu pozornost' vybraným postavám a následne rozhodnút' či, niektorá z postáv reprezentuje vybraný typ leadershipu definovaný stručným opisom.

Kontrola manipulácie - výsledky a diskusia. Štatistická analýza dát prebehla $\mathrm{v}$ štatistickom programe SPSS. Pre zistenie ne/náhodnosti výskytu odpovedí sme použili výpočet Chí-kvadrát. Postava porotcu \#1 predstavujúceho LFL bola správne určená v 36 prípadoch z 57 (63,16\%). Porotca \#3 bol z 57 prípadov v 52 (91,23\%) správne priradený k PTL. Porotcu \#8 (TL) správne určilo 56 participantov z 57 (98,25\%). Pri všetkých 3 porotcoch sa preukázal štatisticky významný rozdiel $(p=0,000)$. Participanti boli schopní úspešne identifikovat' kategórie leadershipu, priradenie druhu vedenia ku konkrétnej postave porotcu nebolo náhodné, metódu sme preto vyhodnotili ako vhodnú na použite v d'alšom výskume.

\section{Výskumné metódy - Angažovanost', dôvera, inovácia}

Angažovanost' bola meraná dotazníkom UWES (Schaufeli, Bakker, \& Salanova, 2006). Škálu tvorí 9 položiek $(0=n i k d y-6=v z ̌ d y)$. Koeficient vnútornej konzistencie: $\alpha=0,962$. Na meranie dôvery bola použitá 7 položková škála $(1=$ vôbec nesúhlasím -5 úplne súhlasím $)$

\footnotetext{
${ }^{3}$ Táto práca je súčast’ou širšie koncipovaného výskumu (Lišková \& Rošková, 2017). Jeho komplexnejší popis a podrobnejšiu argumentáciu použitia metódy filmu je možné nájst’ v práci Liškovej a Roškovej (2017).

4 Podrobné dôvody na zvolenie práve tohto filmu popisujú Christie, Barling a Turner (2011).
} 
Schoormana, Mayera a Davisa (2007). Vnútorná konzistencia škály $\alpha=0,795$. Inovácia bola meraná 10položkovou škálou $(1=n i k d y-5=v z ̌ d y)$ od autorov de Jong a Den Hartog (2008). Koeficient vnútornej konzistencie dosiahol hodnotu $\alpha=0,968$.

\section{Výskumný súbor}

A priori power analýza prostredníctvom programu G*Power indikovala (na základe údajov z výskumu Liškovej a Tomaščíkovej (2017); $\alpha=.05 ; \eta^{2}=.54$; počet skupín:3) potrebnú vel'kost' výberového súboru na 57 participantov. Pilotného výskumu sa zúčastnilo 36 študentov ${ }^{5}(\mathrm{M}=23,81 ; \mathrm{SD}=2,07)-5$ mužov a 31 žien. (Výber výskumného súboru bol náhodilý. Participanti boli náhodne pridelení do 3 skupín (1. TL, 2. PTL, 3. LFL) po 12.

\section{Procedúra}

Participantom bol im predložený informovaný súhlas a dôkladne vysvetlené inštrukcie počas sledovania filmu mali venovat' mimoriadnu pozornost' vybranej postave, všímat' si jej vystupovanie voči ostatým. Participanti boli požiadaní, aby sa odosobnili od vlastných skúseností a plne sa sústredili iba na filmovú situáciu. Po premietnutí filmu si mali participanti predstavit', že by sa postava, ktorej mali venovat' špeciálnu pozornost', takto správala k nim a následne odpovedat’ na škály angažovanosti, dôvery a inovácie.

\section{Výsledky}

$\mathrm{Na}$ štatistickú analýzu výsledkov bol použitý program SPPS. Analýza variancie (ANOVA) odhalila štatisticky významné rozdiely v úrovni angažovanosti $(\mathrm{F}(2,27)=8,094, p$ $=.002)$, dôvery $(\mathrm{F}(2,36)=39,951, \mathrm{p}=.000)$ aj inovácie $\mathrm{F}(2,36)=30,054, \mathrm{p}=.000$.) v závislosti od skúmaných typov leadershipu. Pozorovali sme vysokú mieru sily efektu pre angažovanost' $\left(\eta^{2}=.57\right)$, dôveru $\left(\eta^{2}=.71\right)$, aj inováciu $\left(\eta^{2}=.65\right)$.

Pri angažovanosti post hoc analýza použitím Tukey HSD testu ukázala štatisticky významné rozdiely medzi všetkými kategóriami leadershipu, pričom najvyššia miera angažovanosti bola pozorovaná v podmienke s TL $(\mathrm{M}=39 ; \mathrm{SD}=5,77)$, najnižšia pri podmienke s PTL $(M=17,75 ; \mathrm{SD}=5,79)$. LFL sa umiestnil na „strednej priečke“ $(\mathrm{M}=28,5 ; \mathrm{SD}=11,01)$.

Taktiež dôvera bola signifikantne vyššia pri TL $(\mathrm{M}=25,83 ; \mathrm{SD}=2,59)$ v porovnaní s podmienkou PTL $(\mathrm{M}=14,17,3 ; \mathrm{SD}=3,04)$. Rozdiel vo vnímanej dôvere v podmienke $\mathrm{LFL}$ $(\mathrm{M}=23,33 ; \mathrm{SD}=4,35)$ a TL $(\mathrm{M}=25,83 ; \mathrm{SD}=2,59)$ však nebol štatisticky významný $(p=0,179)$.

Vel'mi podobné výsledky ako pri angažovanosti boli pozorované aj pri inovácii. Medzi všetkými kategóriami leadershipu boli štatisticky významné rozdiely, pričom najvyššia miera inovácie sa preukázala v podmienke s TL $(\mathrm{M}=40,67 ; \mathrm{SD}=5,53)$, najnižšia v podmienke s PTL $(\mathrm{M}=20 ; \mathrm{SD}=5,54)$ a stredná miera inovácie pri $\mathrm{LFL}(\mathrm{M}=29,33 ; \mathrm{SD}=8,18)$.

\footnotetext{
${ }^{5}$ Hoci a priori power analýza odporúčala väčší počet participantov (57), nakol'ko sa jednalo len o pilotné testovanie a náhodilý výber, považujeme počet 36 participantov za dostačujúci na účely pilotného testovania.
} 


\section{Diskusia}

V súlade s H1 sme pozorovali štatisticky významné rozdiely vo všetkých sledovaných pracovných postojoch (angažovanost', dôvera) aj v pracovnom správaní (inovácia) v závislosti od vybraných štýlov vedenia (TL, PTL, LFL) a to s vel'mi vysokou mierou sily efektu. Rovnako ako v našom predošlom výskume (Lišková \& Tomaščíková, 2019) sa aj v tomto prípade ukázal TL ako „najlepší“ spomedzi sledovaných štýlov vedenia. V podmienke s TL participanti vnímali najvyššiu mieru angažovanosti, dôvery aj inovácie. Naopak PTL sa prejavil ako štýl vedenia, pod ktorým participanti pocit’ovali najnižšiu mieru daných postojov a správania.

Rozdiel medzi angažovanost'ou TL a PTL bol viac ako dvojnásobný. Uvedené je v súlade s výsledkami nášho predchádzajúceho výskumu (Lišková \& Tomaščíková, 2019), ako aj v súlade s autormi, ktorí potvrdili pozitívny vzt'ah medzi angažovanost'ou a TL (Kovjanic, Schuh a Jonas, 2013). Domnievame sa, že výsledky priamo odrážajú charakteristiku jednotlivých štýlov, ako ich popisuje aj literatúra - TL vytváraním výziev, entuziazmom, či povzbudzovaním podnecuje angažovanost' (Bass \& Riggio, 2006), kým PTL jej vyslovene bráni (Schuh, Zhang, \& Tian, 2013). Sme toho názoru, že „stredné“ umiestnenie LFL odráža jeho typicky indiferentný prístup, ktorý k angažovanosti nenabáda (ked’že sám o sebe väčšinou angažovaný nebýva) ale zároveň ju ani neblokuje (ked’že mu neprekáža v plánoch).

Pri dôvere nebol rozdiel medzi TL a LFL štatisticky významný, priemerná úroveň dôvery sa v oboch podmienkach líšila na úrovni 2bodov. Daný výsledok interpretujeme tak, že je možné, že vol'nost', ktorá plynie z nezúčastneného prístupu typického pre LFL môže byt' vnímaná aj ako priestor pre vlastné rozhodnutia, činy, resp. ako prejav dôvery zo strany nadriadeného, ako tomu býva pri TL (Lišková \& Tomaščíková, 2019). PTL však ani v tomto prípade neprekvapil a skóre v tejto podmienke bolo najnižšie, čo je v súlade jednak so závermi našej predchádzajúcej práce (Lišková \& Tomaščíková, 2019), práce Christie, Barlinga, a Turnera (2011) ale aj samotnej teórie, podl'a ktorej PTL svojich podriadených zneužíva a nemá na srdci ich dobré záujmy, čo priam vytvára priestor na nedôveru (Bass \& Steidlmeier, 1999).

Úroveň inovácie dopadla vel'mi podobne ako úroveň angažovanosti - najvyššia miera bola pozorovaná pri TL, najnižšia pri PTL, pričom tento rozdiel bol takmer dvojnásobný a LFL dosiahol strednú úroveň. Nakol'ko intelektuálna stimulácia je priamou podstatou TL, a nakol'ko jej bránenie je priamou podstatou PTL, tento výsledok nie je prekvapením a korešponduje s literatúrou (Bass \& Riggio, 2006; Christie, Barling, \& Turner, 2011).

V minulom výskume (Lišková \& Tomaščíková, 2019) typ vedenia vysvetl’oval až $40 \%$ variance angažovanosti, $41 \%$ variancie dôvery a $47 \%$ variancie inovácie. V aktuálnom výskume sme ale pozorovali zásadne vyššiu mieru daných efektov - angažovanost' 57 \%, dôvera $71 \%$ a inovácia 65 \% variancie. Myslíme si, že uvedený nárast môže súvisiet’ s vyššou „názornost’ou“ použitej metódy manipulácie leadershipu. Film vs. vignette (metóda v minulom výskume; Lišková \& Tomačšíková, 2019) poskytuje širší kontext, dáva postávam ovel'a viac priestoru a najmä umožňuje komplexnejšie prejavit' správanie voči okoliu.

$\mathrm{Za}$ najzaujímavejšie považujeme pozorovanie a opakované potvrdenie trendu v postupnosti ,priaznivosti“: TL - LFL - PTL, kde pri TL bola pozorovaná najvyššia miera sledovaných postojov a správania, pri LFL stredná miera a pri PTL najnižšia miera, pričom 
rozdiel medzi TL a PTL bol viac ako dvojnásobný a s výnimkou dôvery, sa LFL v tejto „stupnici“ nachádzal takmer presne v strede. Zaujímavým je pre nás taktiež pozorovanie, že LFL nemusí mat' tak zásadne negatívny vplyv na pracovné postoje, ako mu pripisuje doterajšia literatúra (Ryan \& Tipu, 2013), ale môže vykazovat' charakteristiky, ktoré na pracovné postoje (napr. na dôveru) môžu pôsobit' prospešne - (rozdiel medzi TL a LFL v dôvere bol len 2b).

Uvedomujeme si, že vnímanie leadershipu mohlo byt' ovplyvnené aj ne/sympatiami voči samotným hercom. Nemôžeme tiež vylúčit’ vplyv únavy (napr. klesajúca pozornost') spôsobený dížkou experimentálnej situácie (cca 2,5h) na výsledky. Pri interpretácii sme preto výsledky porovnávali aj s výsledkami Liškovej a Tomaščíkovej (2019), ktorý na manipuláciu leadershipu použil inú metódu (vignette).

Napriek uvedeným limitom však pilotný výskum považujeme za nevyhnutnú prípravu pre realizáciu výskumu na ciel’ovej vzorke zamestnaných respondentov. Výskum umožnil preverit' reprezentatívnost' metódy manipulácie leadershipu, i sebaposudzujúcich škál. Zistenia naznačujú potvrdenia súčasných trendov (pozitívny vplyv TL, negatívny vplyv PTL), platnost' koncepcie leadershipu od autorov Christie, Barlinga a Turnera (2011) a upozorňujú na možný nie nevyhnutne ničivý vplyv LFL na pracovné postoje a správanie zamestnancov (Yang, 2015).

\section{Literatúra}

Bass, B. M., \& Riggio, R. E. (2006). Transformational Leadership. London: Lawrence Erlbaum Associates. http://doi.org/10.4324/9781410617095

Bass, B. M., \& Steidlmeier, P. (1999). Ethics, Character and Authentic Transformational Leadership Behavior. Leadership Quaterly, 10(2), 181-217. http://doi.org/10.1016/S10489843(99)00016-8

Carreiro, H., \& Oliveira, T. (2019). Impact of transformational leadership on the diffusion of innovation in firms: Application to mobile cloud computing. Computers in Industry, 107, 104-113. http://doi.org/10.1016/j.compind.2019.02.006

Contreras, F., Espinosa, J. C., Dornberger, U., \& Acosta, Y. A. C. (2017). Leadership and Employees' Innovative Work Behavior: Test of a Mediation and Moderation Model. Asian Social Science, 13(9), 9-25. http://doi.org/10.5539/ass.v13n9p9

De Jong, J. P. J., \& Den Hartog, D. N., (2008). Innovative Work Behavior: Measurement and Validation. EIM Business and Policy Research, 1-27. Retrieved from: http://ondernemerschap.panteia.nl/pdf-ez/h200820.pdf

Donnely, T. A. (Producer), \& Friedkin, W. (Director). (1997). 12 Angry Men [Motion Picture]. United States of America: MGM Television.

Christie, A., Barling, J., \& Turner, N. (2011). Pseudo-Transformational Leadership: Model Specification and Outcomes1. Journal of Applied Social Psychology, 41(12), 2943-2984. http://doi.org/10.1111/j.1559-1816.2011.00858.x 
Kelloway, E. K., Turner, N., Barling, J., \& Loughlin, C. (2012). Transformational leadership and employee psychological well-being: The mediating role of employee trust in leadership. Work \& Stress, 26 (1), 39-55. http://doi.org/10.1080/02678373.2012.66077

Kovjanic, S., Schuh, S. C., \& Jonas, K. (2013). Transformational leadership and performance: An experimental investigation of the mediating effects of basic needs satisfaction and work engagement. Journal of Occupational and Organizational Psychology, 86(4), 543-555. http://doi.org/10.1111/joop.12022

Lee Whittington, J., \& Galpin, T. J. (2010). The engagement factor: building a highcommitment organization in a low-commitment world. Journal of Business Strategy, 31(5), 14-24. http://doi.org/10.1108/02756661011076282

Lišková, J., \& Rošková, E. (2017). Transformačný, pseudotransformačný a laissez-faire leadership - jeho reflexia v postojoch (angažovanost', dôvera) a v správaní (inovácie) zamestnancov (návrh výskumného projektu). In A. Gregar \& M. Horák (Eds.), Medzinárodni konference - sborník př́spěvků psychologie práce a organizace 2017 pracovní potenciál a jeho proměny v čase (pp. 373-386). Zlín: Univerzita Tomáše Bati ve Zlíne.

Lišková, J., \& Tomaščíková, I. (2019). Reflexia vybraných druhov leadershipu (transformačný, pseudotransformačný a laissez-faire) v angažovanosti, dôvere a inovácii zamestnancov (pilotná fáza výskumu). In P. Kačmár, J. Bavol’ár, \& L. Lovaš (Eds.), Psychológia práce a organizácie 2018 - minulost', prítomnost' a výzvy do budúcnosti. Zborník príspevkov z medzinárodnej konferencie (pp. 284-303). Košice: Katedra psychológie Filozofickej fakulty Univerzity Pavla Jozefa Šafárika v Košiciach.

Robinson, S. L. (1996). Trust and Breach of the Psychological Contract. Administrative Science Quarterly, 41(4), 574-599. http://doi.org/10.2307/2393868

Ryan, J. C., \& Tipu, S. A. A. (2013). Leadership effects on innovation propensity: A twofactor full range leadership model. Journal of Business Research, 66(10), 2116-2129. http://doi.org/10.1016/j.jbusres.2013.02.038

Schaufeli, W. B., Bakker, A. B., \& Salanova, M. (2006). The Measurement of Work Engagement with a Short Questionnaire: A Cross-National Study. Educational and Psychological Measurement, 66(4), 701-716. http://doi.org/10.1177/0013164405282471

Schoorman, F. D., Mayer, R. C., \& Davis, J. H. (2007). An Integrative Model of Organizational Trust: Past, Present, and Future. Academy of Management Review, 32(2), 344-354. http://doi.org/10.5465/amr.2007.24348410

Schuh, S. C., Zhang, X. A., \& Tian, P. (2013). For the good or the bad? Interactive effects of transformational leadership with moral and authoritarian leadership behaviors. Journal of Business Ethics, 116(3), 629-640. http://doi.org/10.1007/s10551-012-1486-0

Tosunoglu, H., \& Ekmekci, O. T. (2016). Laissez-faire leaders and organizations: How does laissez-faire leader erode the trust in organizations? Journal of Economics, Finance and Accounting, 3(1), http://doi.org/89-99. 10.17261/Pressacademia.2016116538 


\section{Korespondující autor}

Mgr. Jana Lišková

Univerzita Komenského v Bratislave, Filozofická fakulta, Katedra psychológie

Gondova 2, 81499 Bratislava

jana.liskova@uniba.sk

Grantová podpora: VEGA 1/0273/18 Rekonceptualizovaný model záväzku v pracovnom kontexte: individuálne a organizačné súvislosti. 


\title{
Consumer behavior in the context of selected socio-demographic characteristics
}

\section{Spotrebitel'ské správanie v kontexte vybraných socio-demografických charakteristík}

Tatiana Lorincová ${ }^{1}$ Ivana Ondrijová ${ }^{2}$

${ }^{1}$ Fakulta manažmentu, Prešovská univerzita v Prešove, Slovensko

${ }^{2}$ Fakulta manažmentu, Prešovská univerzita v Prešove, Slovensko

\begin{abstract}
Consumer materialism is defined as the accumulation of property and subsequent exposure of this property to admiration. Compulsive consumer behavior is a compulsive activity aimed at uncontrolled shopping and consumption. Ethnocentric consumers consider purchasing foreign products to be a bad act in view of the impact on the domestic economy.
\end{abstract}

Objectives. The aim of the contribution is to examine specific forms of consumer behavior in terms of gender and consumer education.

Method. The research sample consisted of 160 respondents, namely 95 women and 65 men aged 18-65 ( $m=35,621, S D=2,578)$. For the research purposes, the Consumer Ethnocentric Tendencies Scale (CETSCALE) was used by Shimpa and Sharma (1987) to determine the level of consumer ethnocentrism. Consumer behavior was also found in two sub-scales inspired by Schiffman and Kanuk (2004), namely the subconscious of consumer materialism and the subconscious of compulsive consumer behavior.

Results. Using t-tests for two independent samples were found statistically significant differences in the level of compulsive consumer behavior in favor of women. At the level of consumer ethnocentrism, consumer materialism and compulsive consumer behavior, there were no statistically significant differences in the secondary and higher education of respondents.

Limitations. The limitation of research study is an occasional choice of research sample.

Keywords. consumer behavior; consumer ethnocentrism; gender; education

https://doi.org/10.5817/CZ.MUNI.P210-9488-2019-17 


\begin{abstract}
Abstrakt
Spotrebitel'ský materializmus je definovaný ako hromadenie majetku a následné vystavovanie tohto majetku na obdiv. Pri nutkavom spotrebnom správaní ide o nutkavú činnost' zameranú na nekontrolované nakupovanie a spotrebu. Etnocentrickí spotrebitelia považujú nákup zahraničných výrobkov za zlý čin vzhl'adom na dopad na domácu ekonomiku.
\end{abstract}

Ciel'e. Ciel'om príspevku je skúmat' špecifické formy spotrebitel'ského správania z hl'adiska rodu a vzdelania spotrebitel'ov.

Metóda. Výskumnú vzorku tvorilo 160 respondentov, konkrétne 95 žien a 65 mužov vo veku od 18 do 65 rokov $(m=35,621, S D=2,578)$. Na výskumné účely bola použitá metodika CETSCALE (Consumer Ethnocentric Tendencies Scale) od autorov Shimpa a Sharma (1987), ktorá zistovala úroveň spotrebitel'ského etnocentrizmu. Spotrebitel’ské správanie bolo zistované aj dvoma subškálami inšpirovanými Schiffmanom a Kanukom (2004), konkrétne subškála spotrebitel'ského materializmu a subškála nutkavého spotrebného správania.

Výsledky. Na základe použitia t- testov pre dva nezávislé výbery boli zistené štatisticky významné rozdiely vúrovni nutkavého spotrebného správania vprospech žien. Vúrovni spotrebitel'ského etnocentrizmu, spotrebitel'ského materializmu a nutkavého spotrebného správania neboli zistené štatisticky významné rozdiely vzhl'adom na stredoškolské a vysokoškolské vzdelanie respondentov.

Limity. Limitom výskumnej štúdie je príležitostný výber výskumnej vzorky.

Kl’účové slová. spotrebitel’ské správanie; spotrebitel'ský etnocentrizmus; rod; vzdelanie

\title{
Teoretické východiská
}

S ekonomickým rozmachom vyspelých krajín intenzívne rastie aj spotreba. Spotrebitel'ské správanie je proces, kedy jednotlivci alebo skupiny vyberajú, nakupujú, používajú a zbavujú sa tovarov, služieb, myšlienok alebo zážitkov, aby naplnili svoje potreby a túžby (Kretter et al., 2008). Spotrebitel'ské správanie vygenerovalo rôzne vlastnosti potreby a vlastníctva smerujúce k špecifickým formám spotrebitel'ského správania, ktoré často krát nemožno považovat' za žiaduce. V našom príspevku sa zaoberáme spotrebitel'ským materializmom, nutkavým nákupným správaním a spotrebitel'ským etnocentrizmom.

Za materialistov označuje Šiler (2014)konzervatívnych jedincov, ktorí sa sústred’ujú na seba a chcú vzbudit' správny dojem, ku ktorému sa hlásia a uznáva ho aj spoločnost' (bohatstvo, úspech). Z tohto dôvodu majú radi (prestížne) značky, aby pomocou nich vyjadrili svoju identitu. Schiffman a Kanuk (2004) uvádzajú tieto charakteristiky materialistických spotrebitel'ov:

- hromadia majetok a vystavujú ho na obdiv,

- sú uzavretí a sebeckí; ich životný štýl je plný majetku,

- ich vel'ký majetok ich neuspokojuje. 
Nutkavá spotreba je prípadom nenormálneho správania, je návyková, pričom spotrebitelia sa v niektorých prípadoch nekontrolujú a ich činy majú pre nich a ich okolie zničujúce následky (Schiffman \&Kanuk, 2004). Nutkavé a impulzívne nakupovanie je vysvetl'ované ako mechanizmus, ktorý znižuje stres spôsobený tlakom okolia na výkon jednotlivca, resp. stres vyplývajúci z nízkeho sebavedomia (Baláž, 2014).

Ako uvádza Ďad'o (2017), spotrebitel'ský etnocentrizmus vychádza zo všeobecných konceptov etnocentrizmu, ktorých základ pramení z viery, že naša skupina je nadradená inej skupine. Etnocentrizmus je forma správania, ktorá chráni vlastnú skupinu pred ostatnými skupinami, prispieva $\mathrm{k}$ identifikácii s vlastnou skupinou a predstavuje významný mechanizmus sociálnej integrácie. Schiffman a Kanuk (2004) poukazujú na to, že vel’mi etnocentrickí spotrebitelia považujú nákup zahraničných výrobkov za nepatričný alebo zlý čin vzhl'adom na dopad na domácu ekonomiku. Neetnocentrickí spotrebitelia naopak oceňujú zahraničné výrobky, často aj pre ich nepodstatné vlastnosti. Spotrebitel'ské správanie sa odlišuje z hl'adiska rodu aj vzdelania spotrebitel'a. Birknerová a Koval'ová (2016) poukazujú na rozdielne spotrebitel'ské správanie mužov a žien. Ich výskum bol zameraný na oblast' manipulácie, angažovanosti, stresu a asertivity pri nakupovaní, kde rod zohrával dôležitú úlohu. Výška vzdelania ovplyvňovala vnímanie, správanie a rozhodovanie človeka $\mathrm{v}$ jeho každodennom živote, a teda aj v spotrebitel'skom správaní.

\section{Metóda}

V našom príspevku boli sledované špecifické formy spotrebitel'ského správania v kontexte rodu a vzdelania spotrebitel'ov. Predpokladali sme existenciu štatisticky významných rodových rozdielov $\mathrm{v}$ úrovni spotrebitel'ského materializmu, nutkavého spotrebného správania a spotrebitel'ského etnocentrizmu. Predpokladali sme existenciu štatisticky významných rozdielov $\mathrm{v}$ úrovni spotrebitel'ského materializmu, nutkavého spotrebného správania a spotrebitel'ského etnocentrizmu vzhl'adom na vzdelanie spotrebitel'ov.

\section{Výskumný súbor}

Výskumný súbor bol tvorený 160 respondentmi vo veku od 18 do 65 rokov ( $\mathrm{m}=35,621$, $\mathrm{SD}=2,578)$, pričom pozostával zo 95 žien a 65 mužov. Respondenti mali ukončené stredoškolské (84 respondentov) a vysokoškolské vzdelanie (56 respondentov). Respondenti boli do výskumnej vzorky vyberaní príležitostným výberom, ktorí pracujú vo verejnom a súkromnom sektore.

\section{Metodika}

Na výskumné účely bola použitá škála Spotrebitel'ského etnocentrizmu (Consumer Ethnocentric Tendencies Scale) od autorov Shimpa a Sharma (1987). Pôvodný 17-položkový model CETSCALE bol orientovaný skôr na amerického spotrebitel'a a zameriaval sa na štyri oblasti súvisiace s ekonomikou krajiny, nezamestnanost'ou, vlastenectvom a dostupnost'ou produktov. Celý model je založený na posudzovaní reakcií respondentov na výroky súvisiace s 
uvedenými oblast’ami. Kvantifikácia odpovedí na jednotlivú otázku používa sedem stupňovú Likertovu škálu, v ktorej hodnota 1 znamená silný nesúhlas a naopak hodnota 7 znamená silný súhlas. Z toho vyplýva, že CETSCALE (sumárny ukazovatel') môže nadobúdat' hodnoty z intervalu $<17 ; 119>$ pričom platí, že čím je hodnota CETSCALE vyššia, tým je etnocentrizmus spotrebitel'ov vyšší. Dôležité je podotknút', že model CETSCALE meria iba celkový etnocentrizmus spotrebitel'ov (Cronbach alfa $=0,868$ ), nezohl'adňuje typ produktu, ale iba miesto výroby (Richterová et al., 2005).

V rámci použitej metodiky bol zist'ovaný aj spotrebitel'ský materializmus použitím metodiky Consumers Values Orientation od autorov Richinsa a Dawsona (1992), ktorý bol reprezentovaný 16 položkami so 7-bodovou škálou súhlasu a nesúhlasu (Cronbach alfa= 0,686). Nutkavé spotrebné správanie bolo zist'ované použitím Compulsive Buying Scale od autorov Valence, Atous a Fortier (1988), pričom bolo prevzatých 5 položiek so 7- bodovou škálou súhlasu a nesúhlasu (Cronbach alfa $=0,714)$. Jednotlivé škály boli použité z publikácie Nákupní chování od autorov Schiffman a Kanuk (2004) v českom preklade od Jungmanna. Pôvodná reliabila jednotlivých položiek bola $\mathrm{v}$ rámci škály CETSCALE $\mathrm{s}$ Cronbach alfa= 0,842, v rámci metodiky Consumers Values Orientation bola Cronbach alfa $=0,91$ a v rámci metodiky Compulsive Buying Scale bola Cronbach alfa $=0,824$.

\section{Výskumné výsledky}

Predmetom výskumnej štúdie bola komparácia spotrebitel'ského etnocentrizmu, spotrebitel'ského materializmu a nutkavého spotrebného správania v kontexte rodu a vzdelania spotrebitel'ov. Výskumné výsledky boli spracované v štatistickom programe IBM SPSS 20.00. Na základe použitia parametrickej rozdielovej štatistiky, konkrétne t-testov pre dva nezávislé výbery, boli zistené výskumné výsledky, ktoré sú prezentované v tab. 1.

Tabulka 1. Komparácia úrovne spotrebitel’ského správania vzhl'adom na rod spotrebitel'ov

\begin{tabular}{cccccccc}
\hline & rod & $\mathrm{n}$ & $\mathrm{M}$ & $\mathrm{SD}$ & $\mathrm{t}$ & $\mathrm{SV}$ & $\mathrm{p}$ \\
\hline $\begin{array}{c}\text { Spotrebitel'ský } \\
\text { etnocentrizmus }\end{array}$ & Ženy & 95 & 2.615 & 0.616 & \multirow{2}{*}{0.014} & \multirow{2}{*}{158} & 0.989 \\
& Muži & 65 & 2.614 & 0.622 & & & \\
Spotrebitel'ský & Ženy & 95 & 2.973 & 0.400 & & & \\
materializmus & Muži & 65 & 2.882 & 0.439 & & & \\
Nutkavé spotrebné & Ženy & 95 & 3.218 & 0.686 & & & \\
správanie & Muži & 65 & 2.983 & 0.717 & & & \\
\hline
\end{tabular}

Na základe tab. 1 je možné konštatovat', že boli zistené štatisticky významné rodové rozdiely $\mathrm{v}$ úrovni nutkavého spotrebného správania $\mathrm{v}$ prospech žien $(\mathrm{t}=2,095 ; \mathrm{p}=0,038)$. V úrovni spotrebitel'ského etnocentrizmu a spotrebitel'ského materializmu neboli zistené štatisticky významné rodové rozdiely. V rámci výskumnej štúdie boli porovnávané jednotlivé zložky spotrebitel'ského správania v kontexte vzdelania spotrebitel'ov. 
Tab. 2.Komparácia úrovne spotrebitel'ského správania vzhladom na vzdelanie spotrebitelov

\begin{tabular}{|c|c|c|c|c|c|c|c|}
\hline & vzdelanie & $\mathrm{n}$ & $\mathrm{M}$ & SD & $\mathrm{t}$ & SV & $\mathrm{p}$ \\
\hline \multirow{2}{*}{$\begin{array}{l}\text { Spotrebitel'ský } \\
\text { etnocentrizmus }\end{array}$} & Stredoškolské & 84 & 2.634 & 0.622 & \multirow{2}{*}{0.813} & \multirow{2}{*}{141} & \multirow{2}{*}{0.417} \\
\hline & Vysokoškolské & 59 & 2.554 & 0.621 & & & \\
\hline \multirow{2}{*}{$\begin{array}{l}\text { Spotrebitel'ský } \\
\text { materializmus }\end{array}$} & Stredoškolské & 84 & 2.949 & 0.417 & \multirow{2}{*}{0.969} & \multirow{2}{*}{141} & \multirow{2}{*}{0.718} \\
\hline & Vysokoškolské & 59 & 2.924 & 0.420 & & & \\
\hline \multirow{2}{*}{$\begin{array}{c}\text { Nutkavé spotrebné } \\
\text { správanie }\end{array}$} & Stredoškolské & 84 & 3.204 & 0.707 & \multirow{2}{*}{0.361} & \multirow{2}{*}{141} & \multirow{2}{*}{0.334} \\
\hline & Vysokoškolské & 59 & 3.083 & 0.767 & & & \\
\hline
\end{tabular}

Na základe tab. 2 je možné konštatovat', že neboli zistené štatisticky významné rozdiely v úrovni spotrebitel'ského etnocentrizmu $(\mathrm{t}=0,813 ; \mathrm{p}=0,417)$ medzi spotrebitel'mi so stredoškolským a vysokoškolským vzdelaním. V úrovni spotrebitel'ského materializmu neboli zistené štatisticky významné rozdiely $(\mathrm{t}=0,969 ; \mathrm{p}=0,718)$ vzhl'adom na vzdelanie spotrebitel'ov a v úrovni nutkavého spotrebného správania taktiež neboli zistené štatisticky významné rozdiely $(\mathrm{t}=0,361 ; \mathrm{p}=0,334)$ medzi spotrebitel'mi so stredoškolským a vysokoškolským vzdelaním.

\section{Diskusia}

Z výsledkov spotrebitel'ského správania u slovenských spotrebitel'ov (Ďad'o, 2017) vyplýva, že väčšina respondentov vykazuje stredne silné až silné etnocentrické spotrebitel'ské tendencie. Najviac sa respondenti stotožňovali s výrobkami, ktoré zdôrazňovali prepojenost' podpory domácej produkcie so zamestnanost'ou a blahobytom krajiny. V oblasti kvality produkcie hodnotila väčšina respondentov potraviny za kvalitnejšie alebo rovnako kvalitné ako zahraničné produkty. Náš výskum poukazuje na to, že v rámci spotrebitel'ského etnocentrizmu nezaznamenávame štatisticky významné rodové rozdiely a rozdiely z hl'adiska vzdelania. $\mathrm{Na}$ základe výskumných výsledkov je možné konštatovat', že muži rovnako ako aj ženy preferujú rovnaký druh výrobkov (domáce výrobky). Rozdiely neboli potvrdené ani medzi spotrebitel'mi so stredoškolským a vysokoškolským vzdelaním, čo naznačuje, že s rastúcou úrovňou vzdelania nedochádza k rozdielom v rámci etnocentrického postoja v spotrebe. Petrusek (2007) uvádza, že čast' spotrebitel'ov sa presúva k post- materiálnym hodnotám. Vysekalová et al. (2011) poukazuje na zaznamenané rozdiely v spotrebitel'skom správaní s čisto materialistickým zameraním a jednotlivcom, ktorý vyznáva post- materialistické hodnoty, a to: udržiavanie poriadku v štáte, právo l'udí spolurozhodovat' v dôležitých verejných záležitostiach, boj proti rastu cien a ochranu slobody prejavu. Petrusek (2007) d’alej uvádza, že tento presun k postmateriálnym hodnotám však nemusí nutne znamenat' zníženie spotreby, aleže spotreba sa presúva smerom z oblasti materiálnej, ktorá predstavuje skôr boj o naplnenie základných potrieb, k oblasti „duchovnej“, pretože sa skôr zmenila povaha materiálnych vecí, ich kvalita a ich sociálna funkcia. Naše výsledky poukazujú na fakt, že ani z hl'adiska rodu, ani z hl'adiska vzdelania nie sú v spotrebitel'skom materializme zaznamenané významné rozdiely. Výskum 
naznačuje, že ženy aj muži sú v spotrebitel'skom správaní z hl'adiska materializmu na rovnakej úrovni. Rovnako tak môžeme predpokladat', že výška vzdelania mieru spotrebitel'ského materializmu nemení.

Výskumníci (Chiger, 2001; Marks, 2002; Otnes \& McGrath, 2001) preukázali rodové rozdiely v kontexte preferencie nákupu a nákupného správania, no napriek moderným tendenciám bagatelizovat' rodové rozdiely je možné konštatovat', že sa ženské a mužské spotrebitel'ské správanie odlišuje na viacerých úrovniach (nákup produktov z rozdielnych dôvodov, prístup k nákupnej úlohe, atd'.)

Výskum od Mattosa et al. (2016) naznačuje, že sa síce rodové rozdiely v nutkavej spotrebe nepreukázali, no na druhej strane boli zistené významné kvalitatívne rozdiely. Konkrétne sa jednalo o mužov so sklonom nebyt' heterosexuálnymi a s nižším vzdelaním. Na druhej strane výskumu od autorov (Dittmar et al., 1996; Rook \& Hoch, 1985) naznačujú, že ženy vd'aka svojej náchylnosti nakupovat' viac ako muži, vo všeobecnosti vykonávajú viac impulzívnych nákupov. V našom výskume sa v nutkavej spotrebe $\mathrm{z}$ hl'adiska rodu štatisticky významné rozdiely potvrdili, pričom ženy inklinovali k takémuto správaniu viac ako muži. Naopak výskum nepreukázal rozdiely v úrovni nutkavej spotreby medzi spotrebitel'mi so stredoškolským a vysokoškolským vzdelaním.

\section{Záver}

$\mathrm{Na}$ špecifické formy spotrebitel'ského správania je možné nahliadat' tak z pohl'adu psychologického, ako aj z pohl'adu obchodníkov. Spotrebitel'ský etnocentrizmus nie je potrebné vnímat' ako problém v osobnosti spotrebitel'a a prístup $\mathrm{k}$ nemu, jeho podpora alebo naopak potláčanie, je vecou názoru viac- menej obchodného pohl'adu. Spotrebitel'ský materializmus súvisí s hodnotou orientáciou osobnosti, pričom jeho podpora môže byt' prospešná hlavne z pohladu obchodníka. Nutkavé spotrebné správanie je z psychologického hladiska istou formou závislosti, ktorú obchodníci využívajú vo vlastný prospech a vnímajú ju pozitívne. Je možné konštatovat', že oblast' spotrebitel'ského správania je multidimenzionálna, ked’že je možné k nej výskumne pristupovat' z viacerých hl'adísk.

\section{Literatúra}

Baláž, V.(2014). Komplexné vol’by. Bratislava: Slovenská akadémia vied.

Birknerová, Z.,\& Koval'ová, J. (2016). Posudzovanie vybraných determinantov nákupného správania z hl'adiska rodu. JOGSC Journal of Global Science, 1(1). http://jogsc.com/pdf/2016/posudzovanie.pdf.

Dittmar, H., Beattie, J.\& Friese, S. (1996). Objects, decision considerations and self-images in men's and women's impulse purchases. Acta Psychologica, 93(1-3), 187-209. http://doi.org/10.1016/0001-6918(96)00019-4

Ďad'o, J. et al.(2006). Marketing služieb. Bratislava: Miroslav Mračko.

Chiger, S. (2001). COnsumer shopping survey. Catalog Age, 18(9), 57-60. 
Kretter, A., et al. (2008). Marketing. Nitra: Slovenská pol'nohospodárska univerzita v Nitre.

Marks, J. (2002) More than a few good men. Home Textiles Today, 23(35), 12-18.

Mattos N. C. et al. (2016). Gender Differences in Compulsive Buying Disorder: Assessment of Demographic and Psychiatric Co-Morbidities. PLoS ONE, 11(12): e0167365. http://doi.org/10.1371/journal.pone.0167365

Otnes, C. \& McGrath, M. (2001) Perceptions and realities of male shopping behavior. Journal of Retailing, 77(1), 11-137. http://doi.org/10.1016/S0022-4359(00)00047-6

Petrusek, M. (2007). Společnosti pozdní doby. Praha: Sociologické nakladatelství.

Richins, L. M., \&Dawson, S. (1992). A Consumer Values Orientation for Materialism and its Measurement: Scale Development and Validation. Journal of Consumer Research, 19(2), 303-316. http://doi.org/10.1086/209304

Rook, D. W., \& Hoch, J. S. (1985). Consuming impulse. Advances in Consumer Research, 12(1), 59-62. http://doi.org/10.1086/208514

Schiffman, L.G., \& Kanuk, L.L.(2004). Nákupní chování. Brno: Computer Press.

Šiler, J.(2014). Vybrané shody o odlišnosti ve spotřebitelském chování Čechů a Slováků. Dostupné z: https://dspace.cuni.cz/bitstream/handle/20.500.11956/72194/DPTX_2012_2_11210_0_381 033 0 138597.pdf? sequence $=1$

Valence, G., d'Astous, A., \& Fortier, L. (1988). Compulsive buying: Concept and Measurement. Journal of Consumer Policy, 11(4), 419-433.

http://doi.org/10.1007/BF00411854

\section{Korespondující autor}

PhDr. Tatiana Lorincová, PhD.

Prešovská univerzita v Prešove, Fakulta manažmentu, Katedra manažérskej psychológie

Konštantínova 16, 080 01, Prešov, Slovenská republika

tatiana.1orincova@unipo.sk

Grantová podpora: Tento výskum bol podporený grantom 0033PU-4/2017 KEGA Implementácia výučby interpersonálních zručností v kontexte predmetu Psychológia obchodu - inovácia obsahu a výučby predmetu. 


\title{
Internal Factors of Work Satisfaction of Employees in Manufacturing Companies in the Czech Republic
}

\section{Vnitřní faktory pracovní spokojenosti zaměstnanců ve výrobních podnicích v ČR}

\author{
Vladimíra Lovasovál, Olexandr Kushch ${ }^{2}$ \\ ${ }^{1}$ Západočeská univerzita v Plzni, Česká republika \\ ${ }^{2}$ Kremenchuk Mykhailo Ostrohradskyi National Universitym, Ukraine
}

\begin{abstract}
Objectives. Manufacturing firms in the Czech Republic today address the increasing staff turnover and the issue of employee satisfaction is very topical. The aim of this study was to find out whether the job satisfaction of manufacturing company employees is influenced by their existential attitudes and personality in the context of Eysenck's dimensions.

Method. The research was carried out in four production plants in the Czech Republic during 2018. Questionnaires DUSIN, EPQ-R and ESK were used.

Results. It has been found that neuroticism and psychoticism negatively correlate with most areas of job satisfaction. Positive correlations were found between job satisfaction and the emotional component of existential attitudes, the ability to make choices, acceptance of responsibility and basic existential moments.

Conclusions. Existential attitudes and moments and Eysenck's personality dimensions of employees most often enter into satisfaction with job opportunities, satisfaction with the job description and satisfaction in the working team, they less affect work evaluation and satisfaction in relationships with superiors.

Limits. The limits of research are mainly that employees of manufacturing companies are treated as a homogeneous group and variables from anamnestic data that would give a more plastic image are not taken into account.The results can be influenced by the fact that the questionnaire filling was very demanding for the respondents. The key question is also whether it is possible to quantify the spiritual qualities of the personality without losing the very essence of existential abilities.
\end{abstract}

Keywords. work satisfaction; neuroticism; psychoticism; existential attitudes

https://doi.org/10.5817/CZ.MUNI.P210-9488-2019-18 


\section{Abstrakt}

Cíl. Výrobní podniky v ČR v současné době řeší rostoucí fluktuaci zaměstnanců a problematika pracovni spokojenosti je velmi aktuální. Cílem předkládané studie bylo zjistit, zda do pracovni spokojenosti zaměstnanců výrobních podniků vstupuji jejich existenciální postoje a osobnost $v$ kontextu Eysenckových dimenzí.

Metody. Výzkum byl realizován ve čtyrech výrobnich podnicích v ČR v průběhu roku 2018 (N = 411) za použití dotazníku DUSIN, EPQ-R a ESK.

Výsledky. Bylo zjištěno, že neuroticismus a psychoticismus negativně korelují s většinou oblastí pracovni spokojenosti. Pozitivni korelace byly shledány mezi pracovní spokojeností a emocionální složkou existenciálních postojů, schopností svobodného rozhodování, přijímání odpovědnosti a základními existenciálními momenty.

Závěry. Existenciální postoje a momenty a Eysenckovy osobnostní dimenze zaměstnance nejčastěji vstupuji do spokojenosti s pracovními možnostmi, spokojenosti s náplní práce a spokojenosti v pracovním kolektivu, méně ovlivňuji spokojenost s pracovním ohodnocením a spokojenost ve vztazich s nadřizenými.

Limity. Limity výzkumu spočívají zejména v tom, že je kzaměstnancưm výrobních podniků přistupováno jako $k$ homogenní skupině a nejsou zohledněné proměnné z anamnestických dat, které by poskytly plastičtějši obraz. Výsledky mohou být zároveň ovlivněny tím, že vyplňování dotazniku bylo pro respondenty velmi náročné. Kličcovou otázkou je také to, zda je vůbec možné duchovni vlastnosti osobnosti kvantifikovat, aniž by se tak vlastni podstata existenciálních schopnosti neztratila.

Klíčová slova. pracovní spokojenost; neuroticismus; psychoticismus; existenciální postoje

\section{Úvod}

Výrobní podniky v ČR se v současné době potýkají se zvyšující se fluktuací zaměstnanců, což přináší nemalé procesní i ekonomické problémy. Z tohoto důvodu je problematika pracovní spokojenosti zaměstnanců ještě více aktuální. Stupeň pracovní spokojenosti zaměstnanců dnes vystupuje jako jedno z klíčových kritérií hodnocení personální politiky podniku. Výrobní podniky se zaměřují na zlepšování pracovních podmínek, snaží se uspokojovat rozvojové potřeby pracovníků a zavádějí stále nové a nové benefity. Programy, které podniky implementují, však mnohdy nepřinášejí očekávané efekty a jednou $\mathrm{z}$ příčin mohou být i osobnostní specifika zaměstnanců.

\section{Teoretická východiska}

Locke (1976) definoval pracovní spokojenost jako afektivní vztah k práci, nebo jako emocionální stav vyplývající z hodnocení a ocenění vlastních pracovních zkušeností. Pracovní spokojenost zahrnuje $\mathrm{v}$ podstatě všechny projevy pracovníka ve vztahu k vykonávané práci, $\mathrm{k}$ pracovnímu zařazení a $\mathrm{k}$ profesi, $\mathrm{k}$ pracovním podmínkám a pracovnímu prostředí, $\mathrm{k}$ pracovišti 
a podniku, k pracovnímu kolektivu (Diener at al., 2002). Podle Luthanse (1992) lze pojem pracovní spokojenost chápat třídimenzionálně, a to jako emoční odpověd' na pracovní situaci, jako reakci na splněné nebo nesplněné očekávání ve vztahu k náplni práce a $\mathrm{k}$ pracovním podmínkám a také jako jev, který vyjadřuje některé vzájemně spjaté postoje. Kollárik (1986) rozlišuje mezi celkovou pracovní spokojenost a dílčí spokojeností s jednotlivými oblastmi.

Celková pracovní spokojenost odráží obecný vztah k vykonávané práci a zahrnuje různé složky dílčí spokojenosti, nap̌r. spokojenost s pracovní činností, se vztahy na pracovišti, s platem, s vyhlídkou na povýšení apod. Pracovní spokojenost je ovlivněna vnějšími a vnitřními faktory, přičemž vnější faktory jsou na pracovníkovi nezávislé. Jedná se např. o finanční ohodnocení, charakter samotné práce, možnost pracovního postupu, způsob vedení, specifika pracovní skupiny a pracovní podmínky (Štikar et al., 2003). Do vnitřních faktorů pracovní spokojenosti vstupuje osobnost pracovníka.

Také Kollárik (1986) považuje pracovní spokojenost za složitý jev, který v sobě zahrnuje a spojuje faktory objektivní i subjektivní související s hodnotami jednotlivců, jejich potřebami a úrovní motivace. Ting (1997) rozlišuje celkem tři oblasti, které se na pracovní spokojenosti podílejí: charakteristiky organizace, charakteristiky vztahující se $\mathrm{k}$ práci a osobnostní charakteristiky. Kollárik (1986) zvláště vyčleňuje motivační faktory, objektivní osobnostní činitele a osobnostní vlastnosti. Motivační faktory zahrnují potřeby, postoje, zájmy, očekávání, plány, aspiraci, z objektivních osobnostních činitelů má na pracovní spokojenost vliv věk, pohlaví, délka zaměstnání v podniku, funkce, rodinný stav a z hlediska osobnostních vlastností jedince se do pracovní spokojenosti promítá např. emocionální stabilita, vyrovnanost, extroverze, frustrační tolerance apod.

Tokar a Subich (1997) ve svém výzkumu stanovili osobnost jako základní prediktor spokojenosti, naopak Furnham, Petrides, Jackson a Cotter (2002) dospěli k závěru, že osobnost nemá silný vliv na pracovní spokojenost. Nejčastěji sledovanými osobnostními charakteristikami ve vztahu k pracovní spokojenosti dosud byly neuroticismus a extraverze (Connoly a Viswesvaran, 2000; Judge, Heller a Mount, 2002; Furnham, Petrides, Jackson a Cotter, 2002). Dalším častým předmětem zájmu mnoha studií je sebehodnocení jedince a signifikantní vztah k pracovní spokojeností prokázalo mnoho autorů (Kollárik, 1986; Abrahamová, 1999; Judge a Bono, 2001; Alavi a Askupir, 2003).

Aktuální výzkumy mapující vliv osobnostních faktorů na pracovní spokojenost se orientují také na oblast duchovní dimenze osobnosti (May, Gilson a Harter, 2004; Tracey, Scott a Kelly, 2011; Garg, 2017). Duchovní dimenze je podle Němčekové (2004) nejužším způsobem spojená se smyslem života a má př́mý dopad na úroveň spokojenosti jednotlivce a úroveň jeho psychické a subjektivní pohody. Např. studie Hu a Hirsh (2017) dokládá, že pracovníci by přijali i nižší počáteční platy za práci, kterou považují za smysluplnou. Frankl (1997) však neustále zdůrazňuje, že smysly se nevytvářejí, ale nalézají. Nemohou nám být poskytnuty a my si můžeme pouze vybrat výzvy, jejichž prostřednictvím smysl nalézáme.

Prožívaná smysluplnost svědčí o schopnosti člověka vyrovnávat se se sebou samým i s vnějšími situacemi a podmínkami vlastního života, a tím smysluplně utvářet svůj život a autenticky jej žít (Längle, 1997). Podle Längleho člověk v rámci procesu nalézání smyslu uplatňuje několik speciálních schopností: schopnost sebeodstupu, sebepřesahu, svobody a 
odpovědnosti. Sebeodstup znamená schopnost poodstoupit od sebe, od svých citů, prání, představ a tím méně zkresleně vnímat situaci. Sebepřesah označuje schopnost vyjít za hranice sebe a svých potřeb a pocitů a schopnost vstoupit do citového vztahu k něčemu či někomu jinému. Svoboda vypovídá o schopnosti rozhodovat se pro možnosti podle vlastního názoru a subjektivního ocenění a odpovědnost zahrnuje schopnost přijmout a nést důsledky svých jednání. Längle, Orgler a Kundi (2001) tyto speciální schopnosti souhrnně považují za existenciální kompetence.

\section{Metoda}

Stávající výzkumy, které se zabývají vlivem osobnostních charakteristik jedince na jeho pracovní spokojenost, vztahují duchovní dimenzi osobnosti především k pracovnímu zapojení, angažovanosti, hodnotám a motivaci. Nepohlížejí na ni jako na dispozici. A lze vůbec o této osobnostní rovině uvažovat jako o možném dispozičním faktoru pracovní spokojenosti? Cílem výzkumu bylo zjistit, zda do pracovní spokojenosti zaměstnanců výrobních podniků vstupují základní existenciální postoje a momenty a ve kterých oblastech pracovní spokojenosti se propojují s Eysenckovými dimenzemi osobnosti.

Do studie bylo zahrnuto 411 zaměstnanců ze čtyř velkých výrobních podniků v ČR. Z hlediska výrobního odvětví se jednalo o automobilový průmysl, farmaceutický průmysl a výrobu elektroniky. Všechny zapojené podniky měly zahraničního vlastníka a marginální podíl vlastního vývoje na území ČR. Výzkumu se účastnilo 192 mužů a 219 žen, nejmladšímu respondentovi bylo 19 let, nejstaršímu 63 let (M 31,4 SD 6,8). Z hlediska organizační struktury byli do šetření zapojeni pracovníci na všech hierarchických úrovních podniku.

Sběr dat byl realizován za použití dotazníku Zjišt’ování struktury a dynamiky životní spokojenosti a frustrogenních podmínek a situací (Mikšík, 2004), Eysenckových osobnostních dotazníků pro dospělé (Eysenck, 1993) a Existenciální škály (Längle, Orgler a Kundi, 2001).

Dotazník Zjištování struktury a dynamiky životní spokojenosti a frustrogenních podmínek a situací DUSIN je zaměřen na subjektivní hodnocení spokojenosti s klíčovými oblastmi života, přičemž každá oblast zahrnuje dvě posuzovací stupnice, škálu důležitosti a škálu naplnění (Mikšík, 2004). Váhový rozdíl mezi nimi určuje míru frustrace a spokojenosti. Za účelem naplnění výzkumného cíle byla pozornost věnována složkám spokojenosti v pracovní oblasti. Pracovní možnosti PM označují subjektivně vnímanou dostupnost přiměřeného zaměstnání či možnosti vhodně podnikat $\mathrm{v}$ dosahu bydliště. Spokojenost s pracovním uspokojením PU se týká náplně práce, zda ji jedinec považuje za zajímavou a schopnostem odpovídající. Pracovní ohodnocení PO zahrnuje informace o tom, zda pracovník vnímá materiální a společenské ohodnocení práce jako odpovídající vynakládané námaze i kvalifikačním nárokům. O percepci možností zvyšovat vlastní kvalifikaci a získat vyšší pracovní zařazení či ocenění vypovídá kategorie perspektivy pracovního růstu PR. Vztahy s nadřízenými VN znamenají hodnocení korektnosti vzájemných vztahů s nadřízenými se smyslem pro vzájemnou úctu a spolupráci. Vztahy se spolupracovníky VS obsahují vzájemné vztahy bez výraznějších konfliktů se smyslem pro spolupráci a vzájemnou pomoc. Do výzkumu byla zahrnuta ještě jedna klíčová oblast dotazníku DUSIN, která postihuje klíčové existenciální 
momenty a obsahuje přiměřenost životních nároků, realizování životních cílů, optimismus a sebedůvěru a celkovou životní spokojenost.

Existenciální škála (ESK) je plně standardizovaný sebeposuzovací dotazník, který měří tzv. schopnost člověka k existenci. Postihuje subjektivní prožívání, vnímání a myšlení ve vztahu k tomu, jak dobře člověk své duchovní schopnosti uplatňuje. Podle autorů Längle, Orgler, Kundi (2001) měří kompetenci zacházet se sebou samým a s okolním světem a připravenost ke smysluplnému životu. ESK sleduje čtyři základní komponenty smysluplného žití: sebeodstup, sebepřesah, svobodu a odpovědnost. První dvě uvedené komponenty spolu tvoří faktor osobních předpokladů, tzv. personalitu, druhé dvě postihují vztah k situačním jevům, existencialitu. Jednotlivé hodnoty vypovídají o tom, jak je př́slušná osobnostní či existenciální schopnost u člověka rozvinuta a jak ji dokáže uplatňovat. Celkové skóre (CS) měří prožívání smysluplné osobní existence.

Za účelem orientačního zachycení možných souvislostí jsou data předkládána v podobě korelačních koeficientů (Pearson). Bližším charakteristikám identifikovaných vztahů budou věnovány následující studie.

\section{Výsledky}

V tabulce č. 1 jsou znázorněny korelační vztahy mezi celkovou pracovní spokojeností i dílčími aspekty pracovní spokojenosti a Eysenckovými dimenzemi osobnosti.

Tabulka 1. Korelace aspektů pracovní spokojenosti k faktorům EPQ-R

\begin{tabular}{lllllllll}
\hline & PM & PU & PO & PR & VN & VS & HO & CPS \\
\hline Psychoticismus & $-0,31^{* *}$ & $-0,27^{* *}$ & $-0,11$ & $-0,15$ & $-0,05$ & $-0,33^{* *}$ & $-0,09$ & $-0,20^{*}$ \\
Extraverze & 0,11 & 0,12 & 0,17 & 0,18 & 0,15 & 0,18 & $0,22^{*}$ & 0,05 \\
Neuroticismus & $-0,24^{*}$ & $-0,26^{* *}$ & $-0,08$ & $-0,26^{* *}$ & $-0,20^{*}$ & $-0,35^{* *}$ & $-0,18$ & $-0,19$
\end{tabular}

Poznámky. PM - pracovní možnosti, PU - pracovní uspokojení, PO - pracovní ohodnocení, PR - perspektivy pracovního růstu, VN - vztahy s nadřízenými, VS - vztahy se spolupracovníky, HO - práce jako hodnota, CPS celková pracovní spokojenost. * $p<0,05 ; * * p<0,01$.

Z Eysenckových dimenzí osobnosti do jednotlivých složek pracovní spokojenosti vstupují neuroticismus a psychoticismus. Míra extraverze se ve výzkumném souboru vztahuje spíše k hodnotám než ke spokojenosti. Přestože stupeň neuroticismu prrímo nekoreluje $\mathrm{s}$ celkovou pracovní spokojeností na statisticky významné úrovni, negativně pưsobí na většinu dílčích oblastí pracovní spokojenosti. Nejsilnější negativní vztah byl identifikován mezi mírou neuroticismu a spokojeností se spolupracovníky, dále možnostmi pracovního růstu, pracovním uspokojením a obecně pracovními možnostmi. Slabá korelace byla zaznamenána ve vztazích s nadř́zeným. Psychoticismus se negativně vztahuje ke spokojenosti ve vztazích s kolegy, spokojenosti s pracovními možnostmi a s pracovním uspokojením. Vztah pracovní spokojenosti k základním existenciálním postojům zachycuje tabulka 2. 
Tabulka 2. Korelace aspektio pracovní spokojenosti k existenciálním postojům v ESK

\begin{tabular}{lllllllll}
\hline & PM & PU & PO & PR & VN & VS & HO & CPS \\
\hline Personalita & $0,28^{* *}$ & $0,28^{* *}$ & 0,13 & 0,15 & 0,11 & $0,28^{* *}$ & 0,18 & 0,14 \\
Existencialita & $0,27^{* *}$ & $0,28^{* *}$ & 0,11 & $0,24^{*}$ & $0,23^{*}$ & $0,26^{* *}$ & $0,20^{*}$ & 0,17 \\
Sebeodstup & 0,11 & 0,16 & $-0,04$ & 0,01 & 0,02 & 0,16 & 0,09 & 0,03 \\
Sebepresah & $0,35^{* *}$ & $0,32^{* *}$ & $0,23^{*}$ & $0,22^{*}$ & 0,16 & $0,33^{* *}$ & $0,21^{*}$ & $0,20^{*}$ \\
Svoboda & $0,27^{* *}$ & $0,24^{*}$ & 0,08 & $0,22^{*}$ & 0,19 & $0,25^{* *}$ & $0,23^{*}$ & 0,12 \\
Odpovědnost & $0,23^{*}$ & $0,28^{* *}$ & 0,13 & $0,24^{*}$ & $0,25^{*}$ & $0,24^{*}$ & 0,15 & 0,19 \\
Smysluplnost & $0,29^{* *}$ & $0,30^{* *}$ & 0,13 & $0,21^{*}$ & 0,19 & $0,29^{* *}$ & $0,20^{*}$ & 0,17 \\
\hline
\end{tabular}

Poznámky. PM - pracovní možnosti, PU - pracovní uspokojení, PO - pracovní ohodnocení, PR - perspektivy pracovního růstu, VN - vztahy s nadř́zenými, VS - vztahy se spolupracovníky, HO - práce jako hodnota, CPS celková pracovní spokojenost. * $p<0,05 ; * * p<0,01$.

U prožívání smysluplné existence (CS) byla vazba nalezena s pracovním uspokojením se spokojeností s pracovními možnostmi a vztahy se spolupracovníky. Sebepřesah se pozitivně vztahuje k pracovním možnostem, ke vztahům se spolupracovníky a k pracovnímu uspokojení. Svoboda se promítá do spokojenosti s pracovními možnostmi a míra odpovědnosti se projevuje v pracovním uspokojení.

Tabulka 3. Korelace aspekti̊ pracovni spokojenosti k existenciálním momentům v DUSIN

\begin{tabular}{lllllllll}
\hline & $\mathrm{PM}$ & $\mathrm{PU}$ & $\mathrm{PO}$ & $\mathrm{PR}$ & $\mathrm{VN}$ & $\mathrm{VS}$ & $\mathrm{HO}$ & $\mathrm{CPS}$ \\
\hline $\begin{array}{l}\text { Seberealizace } \\
\text { Přiměřenost }\end{array}$ & $0,46^{* * *}$ & $0,31^{* *}$ & $0,33^{* *}$ & $0,43^{* * *}$ & 0,18 & $0,34^{* *}$ & 0,18 & $0,54^{* * *}$ \\
živ.nároků & & & & & & & & \\
Realizace živ. cílů & $0,37^{* *}$ & $0,40^{* *}$ & $0,25^{* *}$ & $0,36^{* *}$ & $0,38^{* *}$ & $0,43^{* * *}$ & 0,06 & $0,41^{* * *}$ \\
Sebedůvěra & $0,44^{* *}$ & $0,35^{* *}$ & $0,40^{* *}$ & $0,42^{* * *}$ & $0,26^{* *}$ & $0,28^{* *}$ & 0,04 & $0,42^{* * *}$ \\
Životní spokojenost & $0,35^{* *}$ & $0,27^{* *}$ & 0,13 & $0,36^{* *}$ & $0,22^{*}$ & $0,26^{* *}$ & 0,13 & $0,25 *$ \\
& $0,39^{* *}$ & $0,30^{* *}$ & $0,41^{* * *}$ & $0,34^{* *}$ & 0,13 & $0,35^{* *}$ & 0,08 & $0,35^{* *}$ \\
\hline
\end{tabular}

Poznámky. PM - pracovní možnosti, PU - pracovní uspokojení, PO - pracovní ohodnocení, PR - perspektivy pracovního růstu, VN - vztahy s nadřízenými, VS - vztahy se spolupracovníky, HO - práce jako hodnota, CPS celková pracovní spokojenost; * $\mathrm{p}<0,05 ; * * \mathrm{p}<0,01 * * * \mathrm{p}<0,001$.

Pozitivní korelační vztah mezi celkovou pracovní spokojeností a seberealizací je významný. Z hlediska pracovních aspektů souvisí především s pracovními možnostmi a s perspektivami pracovního růstu. Důležité jsou také vztahy se spolupracovníky, pracovní ohodnocení a uspokojení ze samotné práce. Hodnocení přiměřenosti životních nároků souvisí se všemi oblastmi pracovní spokojenosti v pořadí: vztahy se spolupracovníky, celková pracovní spokojenost, pracovní uspokojení, vztahy s nadřízenými, pracovní možnosti, perspektivy pracovního růstu. Realizování životních cílů je nejvíce odvozováno od pracovních možností, perspektiv pracovního růstu, celkové pracovní spokojenosti, pracovního ohodnocení, pracovního uspokojení. Míra optimistického pohledu na budoucnost a důvěra ve vlastní síly a 
schopnosti jsou závislé zejména na perspektivách pracovního růstu a pracovních možnostech. Pocity spokojenosti s dosavadním průběhem života a se současnou životní realitou pomáhají naplňovat pracovní ohodnocení, pracovní možnosti, vztahy se spolupracovníky a perspektiva pracovního růstu.

\section{Diskuse}

Většina současných výzkumů zaměřených na vliv osobnostních faktorů na pracovní spokojenost se věnuje srovnávání s Velkou pětkou. Např. Judge, Heller a Mount (2002) v rámci metanalytické studie došli $\mathrm{k}$ závěru, že neuroticismus, svědomitost a extraverze jsou signifikantními predikátory míry pracovní spokojenosti. V rámci našeho šetření však stupeň neuroticismu nekoreluje prrímo s celkovou pracovní spokojeností, ale působí na většinu dílčích sledovaných oblastí pracovní spokojenosti.

Ze sledovaných Eysenckových dimenzí se do některých složek pracovní spokojenosti promítl ještě psychoticismus. Jestliže Eysenck (1993) charakterizuje jedince s vysokým skóre v psychoticismu jako samotáře bez zájmu o lidi, často problémové, kteří nikam nezapadají a u kterých se projevuje nedostatek empatie, je logická negativní korelace se spokojeností ve vztazích se spolupracovníky, s pracovními možnostmi i pracovním uspokojení.

Seberealizace v rámci konstrukce dotazníku DUSIN postihuje základní existenciální momenty. Zahrnuje přiměřenost životních nároků, realizování životních cílů, optimismus a sebedůvěru a celkovou životní spokojenost. Pozitivní korelační vztah k celkové pracovní spokojenosti je významný a $\mathrm{z}$ hlediska jednotlivých pracovních aspektů souvisí především s pracovními možnostmi a perspektivami pracovního růstu. Podle Abrahamové (1999) sebehodnocení signifikantně ovlivňuje vztah pracovní spokojenosti i vnímané spravedlnosti a vztahuje se k fluktuaci (Abrahamová, 1999). Také výzkumy Alavi a Askupira (2003) ukazují, že lidé s vyšším sebehodnocením jsou v práci spokojenější, a to s povahou a druhem vykonávané práce, s nadřízeným, spolupracovníky, možnostmi postupu i s platem.

V rámci této studie se sebedůvěra projevila zejména $\mathrm{v}$ hodnocení perspektiv pracovního růstu a pracovních možností. Navíc kategorie ,přiměřenost životních nároků“ a ,realizace životních cílů“, které se vztahují téměř ke všem oblastem pracovní spokojenosti, lze vnímat kontextu Bandurova pojmu self-efficacy. Judge a Bono (2001) v rámci metaanalytické studie prokázali, že se lidé s vysokým vědomím vlastní účinnosti efektivněji vypořádávají s nesnázemi a odolávají lépe selhání. Tím jsou pravděpodobněji schopni dosáhnout ceněných výsledků, což vede ke spokojenosti z práce. Základní existenciální postoje se promítají do pracovního uspokojení, spokojenosti s pracovními možnostmi a se vztahy se spolupracovníky.

Ke všem těmto dílčím aspektům pracovní spokojenosti se vztahuje schopnost citově se angažovat a zaměřit i na jiné hodnoty, než jsem já sám, tzv. sebepřesah. Svoboda jako schopnost nacházet $\mathrm{v}$ běžném životě reálné možnosti jednání a vnímat možnosti volby logicky souvisí s pracovními možnostmi. Míra odpovědnosti je navázána na pracovní uspokojení, nebot' jedinec s nízkými hodnotami v odpovědnosti si život neplánuje, prožívá ho jako nezávislý na vlastní vůli a je zvýšeně pasivní. Právě pracovní uspokojení, spokojenost s pracovními možnosti a se vztahy se spolupracovníky byly identifikovány jako dílčí složky pracovní 
spokojenosti, ve kterých se vliv existenciálních postojů a Eysenckových dimenzí osobnosti propojují.

Z důvodu nedostatku prímo tímto způsobem zaměřených studií lze zatím možný vztah mezi existenciálními kompetencemi a pracovní spokojeností odhadovat od vazby na celkovou spokojenost se životem jako funkce spokojenosti v jednotlivých oblastech, k nimž patři právě práce, rodina, zdraví, přátelé (Hamplová, 2004; Rode 2004; Jones, 2006; Lovasová, 2017). Našemu pojetí se nejvíce přibližuje studie Young, Glerum, Wang a Joseph (2018), ze které v obecné rovině vyplývá, že osobnostní rysy sdílejí mnoho korelací se zkušenou smysluplností.

\section{Závěr}

Eysenckovy dimenze osobnosti nejvíce vztahují k pracovním možnostem, pracovnímu uplatnění a vztahům se spolupracovníky, minimálně ke spokojenosti ve vztahu s nadřízeným

a neovlivňují spokojenost s pracovním ohodnocením. Existenciální postoje zasahují do oblasti pracovních možností, pracovního uspokojení, vztahů se spolupracovníky a perspektiv pracovního růstu, minimálně vstupují do vztahů s nadřízenými a žádný vztah nebyl identifikován k pracovnímu ohodnocení. Základní existenciální momenty se silně promítají v percepci pracovních možností, v pracovním uspokojení, vztazích s kolegy a perspektivách pracovního růstu, méně ve spokojenosti s pracovním ohodnocením a nejméně ve vztazích s nadřízeným. Bez ohledu na sílu korelačního vztahu lze shrnout, že Eysenckovy dimenze osobnosti a existenciální postoje a momenty pracovníka nejvíce ovlivňují pracovní uspokojení, spokojenost s pracovními možnostmi a spokojenost ve vztazích se spolupracovníky. Nejméně vstupují do spokojenosti s pracovním ohodnocením a s jednáním nadřízeného, což jsou také motivační prostředky, se kterými mohou výrobní podniky operativně pracovat.

\section{Literatura}

Abraham, R. (1999). The Relationship Between Differencial Inequity, Intention to Turnover, and Self-Esteem. Job Satisfaction, The Journal of Psychology, 133(2), 205-215. http://doi.org/10.1080/00223989909599734

Alavi, H. R., \& Askaripur, M. R. (2003). The Relationship between self-esteem and jobsatisfaction of Personnel in Government Organizations. Public Personnel Management, 32(4), 591-600. http://doi.org/10.1177/009102600303200409

Connolly, J. J. \& Viswesvaran Ch. (2000). The role of affectivity in job satisfaction: a metaanalysis. Personality and Individual Differences, 29, 265-281. http://doi.org/10.1016/S0191-8869(99)00192-0

Diener, E., Nickerson, C., Lucas, R. E., \& Sandvik (2002). Dispositional effect of job outcomes. Social Indicator Research, 229-259. http://doi.org/10.1023/A:1019672513984

Eysenck, S. G. B., \& Eysenck, H. J. (1993). Eysenckovy osobnostni dotazníky pro dospělé. Bratislava: Psychodiagnostika. 
Frankl, V. E. (1997) Viole ke smyslu. Brno: Cesta.

Furnham, A., Petrides, K. V., Jackson, Ch. J., \& Cotter, T. (2002). Do personality factor predict job satisfaction? Personality and Individual Differences, 33, 1325-1342. https://doi.org/10.1016/S0191-8869(02)00016-8

Garg, N. (2017) Workplace, spirituality and employee well-being: An empirical exploration, Journal of Human Values, 23(2), 129147. http://doi.org/10.1177/0971685816689741

Hamplová, D. (2004). Životní spokojenost: rodina, práce a dalši faktory. Praha: Sociologický ústav AV ČR.

Hu, J., \& Hirsh, J. (2017) The benefits of meaningful work: A meta-analysis. Academy of Management Proceedings, 1, 13866. http://doi.org/10.5465/ambpp.2017.13866

Jones, M. D. (2006). Which is a Better Predictor of Job Performance: Job Satisfaction or Life Satisfaction? Journal of Behavioral and Applied Management, 8(1), 20-42.

Judge, T.A., \& Bono, J.E. (2001). Relationship of core selfevaluations traits - self-esteem, generalized self-efficacy, locus of control, and emotional stability - with job satisfaction and job performance: A meta-analysis. Journal of Applied Psychology, 86, 80-92. http://doi.org/10.1177/009102600303200409

Judge, T. A., Heller, D., \& Mount, M. K. (2002). Five-factor model of personality and job satisfaction: A meta-analysis. Journal of Applied Psychology, 87(3), 530. https://doi.org/10.1037/0021-9010.87.3.530

Kollárik, T. (1986). Spokojnost’v práci. Bratislava: ROH.

Längle, A. (1997). Nalézt přitakání k životu. Propsy, 3(2), 9-11.

Längle, A., Orglerová, C., \& Kundi, M. (2001). Existenciální škála. Praha: Testcentrum.

Locke, E. A. (1976). The nature and causes of job satisfaction. Handbook of industrial and organizational psychology. Chicago: Rand McNally, 1297-1349.

Lovasová, V. (2017). Souvislosti neuroticismu. Plzeň: ZČU.

Luthans, F. (1992). Organizational Behaviour. New York: Mc GrawHill.

D.R. May, D.R., Gilson, R. L. \& Harter, L. M. (2004). The psychological conditions of meaningfulness, safety and availability and the engagement of the human spirit at work. Journal of Occupational and Organizational Psychology, 77(1), 11-37. https://doi.org/10.1348/096317904322915892

Mikšík, O. (2004) Dotazník DUSIN - zjištováni struktury a dynamiky životní spokojenosti a frustrogennich podmínek a situací. Bratislava: Psychodiagnostika, s.r.o.

Nemčeková, M. (2004). Práva pacientov. Martin: Osveta.

Rode, J. C. (2004). Job satisfaction and life satisfaction revisited: A longitudinal test of an integrated model. Human Relations, 57(9), 1205-1230. https://doi.org/10.1177/0018726704047143 
Štikar, J., Rymeš, M., Riegel, K., \& Hoskovec, J. (2003). Psychologie ve světě práce. Praha:Karolinum.

Ting, Y. (1997). Determinants of Job Satisfaction of Federal Government Employees. Public Personnel Management, 26(3), 313-334. https://doi.org/10.1177/009102609702600302

Tokar, D. M. \& Subich, L. M. (1997). Relative Contributions of Congruence and Personality Dimensions to Job Satisfaction. Journal of Vocational Behavior. 50(3), 482-491. https://doi.org/10.1006/jvbe.1996.1546

Tracey E. R., Young, J. S. Kelly, V. A. (2011). Spiritual Well-Being and Job Satisfaction: A Preliminary Study, 50(3), 165-175. https://doi.org/10.1002/j.2161-007X.2006.tb00053.X

Young, H. R., Glerum, D. R., Wang, W. Joseph, D. L. (2018) Who are the most engaged at work? A meta-analysis of personality and employee engagement. Journal of organizational behavior, 39(10), 1330-1346. https://doi.org/10.1002/job.2303

\section{Korespondující autor}

Mgr. Vladimíra Lovasová, Ph.D.

Západočeská univerzita v Plzni, Fakulta pedagogická, Katedra psychologie

Univerzitní 8, 30100 Plzeň, ČR

lovasova@kps.zcu.cz 


\title{
Effectiveness of mindfulness training programs in improving work stress management in teachers
}

\section{Efektivita mindfulness tréningov v zlepšení zvládania pracovného stresu u učitel’ov} Alexander Loziak ${ }^{1}$

${ }^{1}$ Centre of Social and Psychological Sciences, Slovak Academy of Science, Institute of Social Sciences, Košice. Slovakia

\begin{abstract}
Objective. The main aim of the study is to describe current scientific knowledge about effectivity of so-called mindfulness training programs that are focusing on improving work stress management in teachers. Nowadays, teaching is one of the most stressful professions. Nevertheless, we pay very little attention to educating teachers about stress management skills (Meiklejohn et al., 2012). Mindfulness is the ability to focus attention on present moment with open and non-judgmental attitude. Its practice belongs to most promising ways how to help teachers handle their work load (Emerson et al., 2017).
\end{abstract}

Method. This paper is literature review that analyses 10 current studies which concerned with effect of mindfulness training programs on teacher's work stress. Trainings included education about mindfulness principles and its individual and group practices. Every analyzed study was published in 2012 or later.

Results. Results of the study indicates high effectivity of mindfulness-based programs. All analyzed resources repeatedly show programs lower stress and negative emotions and improve emotional regulation ability.

Conclusions. Issue of teacher work stress requires more attention in research but also in practice. Mindfulness training programs might be a solution.

Limitations. Limitations of the paper are caused by its briefness because we were not able to grasp specificity of each intervention.

Keywords. work stress; mindfulness; teacher

https://doi.org/10.5817/CZ.MUNI.P210-9488-2019-19 


\begin{abstract}
Abstrakt
Ciele. Cielom príspevku je približit' aktuálne vedecké poznanie o efektivite takzvaných mindfulness tréningov, ktoré sú zamerané na zlepšenie manažmentu stresu u učitel'ov. Učitel'stvo je $v$ súčasnej dobe jedno $z$ najstresujúcejšich povolaní. Aj napriek tomu sa vzdelávaniu učitel’ov o schopnostiach zvládania stresu venuje málo pozornosti (Meiklejohn a kol., 2012). Mindfulness je schopnost'zamerat' pozornost' na súčasný moment s otvorenost'ou a nekritickostou. Jej nácvik patrí k najslubnejším spôsobom, ako pomôct' učitel'om zvládat' ich pracovnú zátaž (Emerson a kol., 2017).
\end{abstract}

Metóda. Príspevok je prehl’adová štúdia, ktorá analyzuje 10 súčasných štúdií, ktoré sa zaoberali efektom mindfulness tréningov na pracovný stres učitelov. Tréningy zahŕñali učenie mindfulness princípov, a ich individuálne aj skupinové precvičovanie. Každá analyzovaná štúdia bola publikovaná v roku 2012 alebo neskôr.

Výsledky. Výsledky tohto príspevku poukazujú na efektivitu mindfulness tréningov. Všetky analyzované zdroje opakovane ukazujú na zníženie stresu a negatívnych emócii u učitel'ov a zvýšenú schopnost' emočnej regulácie.

Závery. Otázka stresu učitel’ov vyžaduje viac pozornosti, výskumne a tiež prakticky. Mindfulness tréningy by mohli byt' riešením.

Limity. Limity príspevku sú spôsobené jeho stručnost'ou, ked’že sme nedokázali zachytit' špecifickost' jednotlivých intervencií.

Kl’účové slová. pracovný stres; mindfulness; učitel'

\title{
Úvod
}

\section{Učitel'stvo a pracovný stres}

Učitelia hrajú kl'účovú rolu vo vytváraní triednej a školskej klímy, ktorá ponúka žiakom vhodné podmienky nielen na učenie, ale aj na správny sociálny a emocionálny vývin. Avšak učenie a zvládanie školskej triedy môže byt' stresujúce. Učitel'stvo je ako profesia spájaná s vysokou pracovnou fluktuáciou, často spôsobenou syndrómom vyhorenia. 40 \% učitel'ov v USA opúšt’a profesiu behom prvých 5 rokov (Ingersoll, 2002) a 73 \% čerstvo kvalifikovaných učitel'ov vo Vel'kej Británii zvažuje odchod zo zamestnania (Flook a kol., 2013).

Stres z práce zasahuje učitel'om do viacerých oblastí života. Nesie so sebou dva druhy závažných dôsledkov - dôsledky v pracovnej sfére a dôsledky v osobnej sfére. V rámci pracovných dôsledkov môže stres napríklad narušit' vzt'ah učitel'-žiaci. Ked' sa učitelia nevedia efektívne vyrovnat' so zát'ažou, zhoršuje sa komunikácia a následne vzt'ah so žiakom. Na to nadväzuje zhoršenie akademických výsledkov aj správania žiakov (Meece, Eccles, 2010).

Chronický stres môže rovnako viest' k vážnym osobným dôsledkom, napríklad k syndrómu vyhorenia. Syndróm vyhorenia sa najčastejšie vyskytuje práve v pomáhajúcich a pedagogických profesiách. Vyhorenie, ako akumulácia reakcií na stresory v práci, je charakterizované emocionálnym vyčerpaním, nízkou seba-účinnost'ou, cynizmom a nižšou kvalitou života (Bentea, 2017; Maslach, Schaufeli, Leiter, 2001). 
Emocionálne vyčerpanie a nízka seba-účinnost' pramenia $\mathrm{z}$ t’ažko zvládnutel'ných pracovných požiadaviek a $\mathrm{z}$ nedostatočných zdrojov tieto nároky zvládat'. Ak nenastáva zmiernenie stresu, učitel'om hrozí cynizmus - strácajú ideály, nadšenie pre profesiu slabne, ich emócie sú narušené. V týchto prípadoch je obzvlášt' dôležitá efektívna emocionálna regulácia (Herman, Hickmon-Rosa, Reinke, 2017).

Berúc do úvahy tieto nepriaznivé dopady stresu na učitel’ov, je prekvapivé, ako málo pozornosti tomuto problému venujeme (Meiklejohn a kol., 2012). Zdá sa nevyhnutné identifikovat' programy, ktoré učitel'om dokážu pomôct'. Tieto intervencie by mali adresovat' zlepšenie emocionálnej regulácie $\mathrm{v}$ náročných situáciách a mali by učitel'a podporovat' v udržaní si zdravia aj v pohodovom vykonávaní svojej profesie (Emerson a kol., 2017).

\section{Mindfulness}

Mindfulness je schopnost' zamerat' pozornost' na súčasný moment s otvorenost'ou a nekritickost'ou (Emerson a kol., 2017).

Podl'a definície Kabata-Zinna je mindfulness uvedomovanie si, ktoré vyplýva z úmyselného sústredenia pozornosti na prítomný moment, okamih za okamihom (Kabat-Zinn, 2003). Podstata stavu „okamih za okamihom“ spočíva v plnej prítomnosti v danej chvíli, bez posudzovania, bez hodnotenia, bez spätného premietania spomienok, bez pohl'adu do budúcnosti, ktoré v nás vzbudzujú starosti. A tiež bez snahy menit' prítomnost' alebo vyhnút' sa nepríjemným aspektom v danej situácii (Teasdale, Segal, Williams, 1995).

Mindfulness je teda plné vedomie, plná bdelost' v prítomnom okamihu. To zahŕňa bdelost' na úrovni všetkých zmyslov: zrakovú, sluchovú, chut'ovú a hmatovú bdelost'. Tiež ide o bdelost' na úrovni poznávacej, vedomej a emocionálnej (Napoli a kol., 2005).

Definície mindfulness najčastejšie zahrňujú dva základné pojmy - pozornost' (attention) a uvedomenie si (awareness). Pozornost' môžeme definovat' ako proces zaostrovania vedomia, ktoré zvyšuje citlivost' voči obmedzenému rozsahu skúseností. Jeho základnou vlastnost'ou je selektivita. Vedomie a pozornost' sú teda vzájomne prepojené tak, že pozornost' vyberá „figúru“ z ,pozadia“ vedomia a zámerne ju udržuje na rôzne dlhú dobu. Uvedomenie sa popisuje ako „radar“, v pozadí vedomia, ktorý neustále monitoruje vnútorné a vonkajšie prostredie. Rozvinutost' týchto schopností bola korelovaná s nižšou úzkostlivost'ou, depresiou a naopak vyšším pozitívnym afektom a životnou spokojnost’ou (Brown, Ryan, 2003).

Tréning mindfulness princípov opakovane ukazuje na zlepšenie indikátorov psychického zdravia. Jeho účinnost' sa spája aj so zlepšením emocionálnej regulácie, čo je kl'účový komponent schopnosti učitel'ov zvládat' svoju prácu (Emerson et al., 2017). Taktiež jeho relatívna finančná a časová nenáročnost' poskytuje vel'kú výhodu pri práci s učitel'mi. Výskum poukazuje, že mindfulness intervencie môžu byt’ zmysluplným nástrojom zvládania stresu učitel'ov.

Avšak závery výskumov uskutočnených na všeobecnej populácií a teoretické predpoklady nestačia k utvoreniu jasnejších záverov. Preto je ciel'om tejto prehl'adovej štúdie zreferovat' súčasné zistenia ohl'adom efektu mindfulness intervencií na pracovný stres 
konkrétne v populácii učitel'ov.

Vzhl'adom na literatúru nás zaujímajú tieto premenné - zníženie vnímaného pracovného stresu, zníženie vnímaných symptómov vyhorenia, zníženie vnímanej úzkosti, zníženie fyziologických symptómov stresu a tiež zlepšenie emocionálnej regulácie a celkovej životnej spokojnosti (pohody). Vybrali sme štúdie s kontrolou skupinou a meraniami pred a po intervencii. Prínosom tejto štúdie je jasný obraz o tom, či sú mindfulness intervencie dobrým riešením prebiehajúcej krízy stresu medzi učitel’mi.

\section{Metóda}

Do analýzy sme zaradili len pôvodné štúdie, avšak na ich vyhl'adávanie sme využili aj iné prehl'adové a meta-analytické štúdie. Vyhl'adávali sme ich pomocou vedeckých elektronických databáz: Google Scholar, ScienceDirect, Scopus, Microsoft Academic Research, Web of Science a DOAJ.

Tri základné kritéria výberu zahŕňali: výskumy boli založené na mindfulness intervenciách, merali redukciu pracovného stresu a vzorka pozostávala z učitel’ov základných a stredných škôl. Štúdie sme teda vyhl'adávali na základe hesiel: „,mindfulness“, „,mindfulness intervention“, „stress“, „,work stress“, „,occupational stress“, „teachers“.

Ďalšími kritériami výberu boli rok publikovania štúdií a dizajn výskumu. Aby sme sa zamerali na aktuálny výskum, vybrali sme štúdie publikované najneskôr v roku 2012. Za adekvátny dizajn výskumu sme považovali prítomnost' kontrolnej skupiny a meranie premenných pred a po intervencii.

Štúdie pracovali s rôznorodými mindfulness intervenciami. Niektoré tréningy boli založené na učení mindfulness princípov, iné tréningy boli formálnejšie a pozostávali z individuálneho aj skupinového precvičovania rôznych meditácií.

Okrem efektu na pracovný stres väčšina z týchto štúdii mapovali aj efekt na iné závislé premenné, ktoré so stresom súvisia - úzkost', fyziologické prejavy stresu (stresové hormóny, kvalita spánku), celková pohoda či emocionálna regulácia. Len tri z vybraných štúdií merali efekt aj s väčším časovým odstupom (dva až tri mesiace).

\section{Výsledky}

$\mathrm{Na}$ základe určených kritérií sme vybrali 10 pôvodných štúdií. Súhrnné výsledky potvrdzujú efektivitu mindfulness programov na redukciu pracovného stres učitel'ov. 9 z 10 štúdií priamo poukazujú na redukciu stresu alebo symptómov vyhorenia, ktoré súvisia s vykonávaním učitel'skej profesie.

Výskum Franka síce nepotvrdil signifikantné zlepšenie symptómov vyhorenia, avšak dôsledkom mindfulness programu sa dokázalo zlepšenie kvality spánku (Frank a kol., 2015). Kvalita spánku sa považuje za spol'ahlivý indikátor hladiny stresu. Viaceré z výskumov preukázali aj zvýšenie celkovej životnej pohody. Súčastou polovice nájdených štúdií bolo aj zist'ovanie efektu mindfulness programov na emocionálnu reguláciu. Všetkých 5 štúdií, ktoré sa zaoberali touto premennou potvrdili, že mindfulness programy majú pozitívny vplyv na 
emocionálnu reguláciu. Informácie o jednotlivých štúdiách a ich výsledky sú zhrnuté v tabul'ke (vid'. Tabul'ka 1).

Tabul'ka 4. Súhrnné informácie a výsledky štúdií

\begin{tabular}{|c|c|c|c|c|}
\hline Autor, rok & Dizajn, metóda & Záv. premenné & Vzorka & Hlavné zistenia \\
\hline $\begin{array}{l}\text { Benn a kol. } \\
\text { (2012) }\end{array}$ & $\begin{array}{l}\text { Nezávislé skupiny, } \\
\text { pre-post test, } \\
\text { dlhodobý efekt }\end{array}$ & $\begin{array}{l}\text { Pracovný stres, } \\
\text { úzkost', } \\
\text { emocionálna } \\
\text { regulácia }\end{array}$ & 38 & $\begin{array}{l}\text { Redukcia stresu } \\
\text { a úzkosti aj po } 2 \\
\text { mesiacoch, zlepšenie } \\
\text { emoc. regulácie }\end{array}$ \\
\hline $\begin{array}{l}\text { Beshai a kol. } \\
\text { (2016) }\end{array}$ & $\begin{array}{l}\text { Nezávislé skupiny, } \\
\text { pre-post test }\end{array}$ & $\begin{array}{l}\text { Pracovný stres, } \\
\text { celková pohoda }\end{array}$ & 89 & $\begin{array}{l}\text { Redukcia stresu } \\
\text { a zvýšenie pohody }\end{array}$ \\
\hline $\begin{array}{l}\text { Flook a kol. } \\
\text { (2013) }\end{array}$ & $\begin{array}{l}\text { Nezávislé skupiny, } \\
\text { pre-post test }\end{array}$ & $\begin{array}{c}\text { Symptómy } \\
\text { vyhorenia, stresové } \\
\text { hormóny }\end{array}$ & 19 & $\begin{array}{c}\text { Zníženie symptómov } \\
\text { vyhorenia a stres. } \\
\text { hormónov }\end{array}$ \\
\hline $\begin{array}{l}\text { Frank a kol. } \\
\text { (2015) }\end{array}$ & $\begin{array}{l}\text { Nezávislé skupiny, } \\
\text { pre-post test }\end{array}$ & $\begin{array}{c}\text { Symptómy } \\
\text { vyhorenia, kvalita } \\
\text { spánku, emoc. } \\
\text { regulácia }\end{array}$ & 36 & $\begin{array}{l}\text { Žiadne zlepšenie sym. } \\
\text { vyhorenia, lepšia kvalita } \\
\text { spánku, lepšia emoc. } \\
\text { regulácia }\end{array}$ \\
\hline $\begin{array}{l}\text { Harris a kol. } \\
\text { (2015) }\end{array}$ & $\begin{array}{l}\text { Nezávislé skupiny, } \\
\text { pre-post test }\end{array}$ & $\begin{array}{l}\text { Tolerancia stresu, } \\
\text { stresové hormóny }\end{array}$ & 64 & $\begin{array}{l}\text { Zlepšenie tol. stresu, } \\
\text { zníženie st. hormónov }\end{array}$ \\
\hline $\begin{array}{l}\text { Jenaabadi a } \\
\text { kol. (2017) }\end{array}$ & $\begin{array}{c}\text { Nezávislé skupiny, } \\
\text { pre-post test }\end{array}$ & $\begin{array}{l}\text { Pracovný stres, } \\
\text { celková pohoda }\end{array}$ & 30 & $\begin{array}{l}\text { Redukcia stresu, } \\
\text { zvýšenie pohody }\end{array}$ \\
\hline $\begin{array}{l}\text { Jennings a } \\
\text { kol. (2017) }\end{array}$ & $\begin{array}{l}\text { Nezávislé skupiny, } \\
\text { pre-post test }\end{array}$ & $\begin{array}{l}\text { Stres, emoc. } \\
\text { regulácia }\end{array}$ & 224 & $\begin{array}{l}\text { Zníženie stresu, lepšia } \\
\text { emoc. regulácia }\end{array}$ \\
\hline $\begin{array}{l}\text { Jennings a } \\
\text { kol. (2013) }\end{array}$ & $\begin{array}{l}\text { Nezávislé skupiny, } \\
\text { pre-post test }\end{array}$ & $\begin{array}{l}\text { Symptómy stresu, } \\
\text { celková pohoda, } \\
\text { emoc. regulácia }\end{array}$ & 50 & $\begin{array}{l}\text { Redukcia stresu, } \\
\text { zvýšenie pohody, } \\
\text { zlepšenie e. regulácie }\end{array}$ \\
\hline $\begin{array}{l}\text { Roeser a kol. } \\
\text { (2013) }\end{array}$ & $\begin{array}{l}\text { Nezávislé skupiny, } \\
\text { pre-post test, } \\
\text { dlhodobý efekt }\end{array}$ & $\begin{array}{c}\text { Symptómy } \\
\text { vyhorenia, úzkost' }\end{array}$ & 113 & $\begin{array}{l}\text { Redukcia vyhorenia } \\
\text { a úzkosti aj po } 3 \\
\text { mesiacoch }\end{array}$ \\
\hline $\begin{array}{l}\text { Taylor a kol. } \\
\text { (2016) }\end{array}$ & $\begin{array}{l}\text { Nezávislé skupiny, } \\
\text { pre-post test, } \\
\text { dlhodobý efekt }\end{array}$ & $\begin{array}{c}\text { Symptómy } \\
\text { pracovného stresu, } \\
\text { emoc. regulácia }\end{array}$ & 59 & $\begin{array}{l}\text { Redukcia symptómov } \\
\text { pracovného stresu, } \\
\text { zlepšenie e. regulácie }\end{array}$ \\
\hline
\end{tabular}

\section{Diskusia}

Zámerom tejto prehl'adovej štúdie bol prehl'ad súčasných štúdii s adekvátnym dizajnom výskumu, ktoré sa zaoberali efektom mindfulness programov na redukciu pracovného stresu učitel'ov. Z našej analýzy vyvodzujeme niekol'ko záverov a myšlienok.

Precvičovanie mindfulness ponúka na základe literatúry mnoho psychologických, aj praktických benefitov. Hoci prospešnost' tohto prístupu (a z neho odvodených techník) je 
nesporná, je otázne, za akých podmienok je možné túto prospešnost' reálne využit'. Škola je pracovné prostredie, v ktorom sa stretáva množstvo stresových faktorov - pomôct' učitel'om s ich každodennou zát'ažou je vel'ká výzva. Je precvičovanie mindfulness dostatočne efektívne, aby pomohlo nie len ako všeobecný princíp (a možno prístup k životu), ale aj ako konkrétne riešenie?

Výsledky tejto štúdie naznačujú, že mindfulness by mohlo byt' súčast'ou riešenia. Aj ked' je náročné pohybovat' sa v spleti rôznych symptómov a faktorov, ktoré poukazujú na stres (a zlepšenie stresu), zdá sa, že tento typ intervencií prospieva „celkovému obrazu“ vnímania zát’aže. Premenné spojené so stresom následkom intervencií ukázali skôr klesajúcu tendenciu, naopak premenné spojené s prevenciou proti stresu, ako emocionálna regulácia a životná spokojnost', stúpli. Výsledky sú konzistentné a vcelku presvedčivé.

Tieto výsledky však vo väčšine prípadov ukazujú len na okamžitý stav po intervencii, dlhodobý efekt (po dobe dvoch a troch mesiacov) preukázali len $3 \mathrm{z}$ analyzovaných štúdií. Je teda diskutabilné, či mindfulness intervencie dokážu priniest' benefity, ktoré sú trvalé a dokážu obstát' aj v dlhodobom horizonte. Existuje totiž riziko, že hoci mindfulness dokáže priniest' okamžitú úl'avu, nedokáže učitel’om ponúknut' spol’ahlivý nástroj, ktorý by sami aktívne využívali na zvládanie stresu aj v budúcnosti. Dlhodobé precvičovanie a „pestovanie“ mindfulness totiž predstavuje záväzok vyžadujúci vel’a energie a vnútornej motivácie.

Prínos tejto štúdie je v tom, že ponúka súčasný obraz mindfulness intervencií ako sl’ubnej a užitočnej metódy pomoci učitel'om. Táto prehl'adová štúdia sa nezameriava striktne na jednu premennú, ktorou by mohol byt' vnímaný stres, ale mapuje celú škálu rôznych indikátorov pracovnej zát'aže. Veríme, že stručne a efektívne zhrňuje dôležité výsledky spol'ahlivých výskumov v tejto oblasti od roku 2012.

Limity tejto štúdie vidíme v tom, že stručnost' štúdie obmedzila informácie týkajúce sa špecifík jednotlivých intervencií. Mindfulness je široký pojem a spôsob, ako konkrétne sa vyučuje a precvičuje je nepochybne podstatným faktorom zasahujúcim do celkových výsledkov. Tento limit sa dá z časti ospravedlnit’ tým, že v rámci výskumov nie je možné verne opísat' hĺbku, kvalitu a rozsah konkrétnej intervencie - preto sme tieto informácie pri opise jednotlivých programov nezhrnuli.

$\mathrm{Na}$ základe našich výsledkov odporúčame, aby sa d’alšie skúmanie mindfulness intervencií na pracovný stres u učitel'ov sústredilo najmä na jeho dlhodobý efekt. Považujeme za kl'účové zistit', či sú mindfulness intervencie schopné zabezpečit' skutočnú a trvalú zmenu.

\section{Literatúra}

Benn, R., Akiva, T., Arel, S., \& Roeser, R. W. (2012). Mindfulness training effects for parents and educators of children with special needs. Developmental Psychology, 48(5), 1476-1487. http://doi.org/10.1037/a0027537

Bentea, C. (2017). Teacher Self-Efficacy, Teacher Burnout And Psychological Well-Being. In The European Proceedings of Social \& Behavioural Sciences (pp. 1128-1135). http://doi.org/10.15405/epsbs.2017.05.02.139 
Beshai, S., McAlpine, L., Weare, K., \& Kuyken, K. (2016). A non-randomised feasibility trial assessing the efficacy of a mindfulness-based intervention for teachers to reduce stress and improve well-being. Mindfulness, 7(1), 198-208. http://doi.org/10.1007/s12671-015-0436$\underline{1}$

Brown, K. W., \& Ryan, R. M. (2003). The benefits of being present: mindfulness and its role in psychological well-being. Journal of Personality and Social Psychology, 84(4), 822848. http://doi.org/10.1037/0022-3514.84.4.822

Emerson, L., Leyland, A., Hudson, K., Rowse, G., Hanley, P., \& Hugh-Jones, S. (2017). Teaching Mindfulness to Teachers: A Systematic Review and Narrative Synthesis. Mindfulness, 8(5), 1136-1149. http://doi.org/10.1007/s12671-017-0691-4

Flook, L., Goldberg, S. B., Pinger, L., Bonus, K., \& Davidson, R. J. (2013). Mindfulness for Teachers: A Pilot Study to Assess Effects on Stress, Burnout, and Teaching Efficacy. Mind, Brain, and Education, 7(3), 182-195. http://doi.org/10.1111/mbe.12026

Frank, J. L., Reibel, D., Broderick, P., Cantrell, T., \& Metz, S. (2015). The effectiveness of mindfulness-based stress reduction on educator stress and well-being: results from a pilot study. Mindfulness, 6(2), 208-216. http://doi.org/10.1007/s12671-013-0246-2

Harris, A. R., Jennings, P. A., Katz, D. A., Abenavoli, R. M., \& Greenberg, M. T. (2015). Promoting stress management andwellbeing in educators: Feasibility and efficacy of a school-based yoga and mindfulness intervention. Mindfulness, 7(1), 143-154. http://doi.org/10.1007/s12671-015-0451-2

Herman, K. C., Hickmon-Rosa, J., \& Reinke, W. M. (2017). Empirically Derived Profiles of Teacher Stress, Burnout, Self-Efficacy, and Coping and Associated Student Outcomes. Journal of Positive Behavior Interventions, 20(2), 90-100.

http://doi.org/10.1177/1098300717732066

Ingersoll, R. M. (2002). The Teacher Shortage: A Case of Wrong Diagnosis and Wrong Prescription. NASSP Bulletin, 86(631), 16-31. http://doi.org/10.1177/019263650208663103

Jenaabadi, H., Pilechi, L., Salmabadi, M., \& Rad, A.T. (2017). Effectiveness of training mindfulness skills in professional stress and psychological well-being of female teachers. Iran Occupational Health, 13(6), 57-69.

Jennings, P. A., Brown, J. L., Frank, J. L., Doyle, S., Oh, Y., Davis, R., ...Greenberg, M. T. (2017). Impacts of the CARE for teachers program on teachers' social and emotional competence and classroom interactions. Journal of Educational Psychology, 109(7), 1-19. 10.1037/edu0000187.

Jennings, P. A., Frank, J. L., Snowberg, K. E., Coccia, M. A., \& Greenberg, M. T. (2013). Improving classroom learning environ-ments by cultivating awareness and resilience in education (CARE): results of a randomized controlled trial. School Psychology Quarterly, 28(4), 374-390. http://doi.org/10.1037/spq0000035 
Kabat-Zinn, J. (2003). Mindfulness-Based Interventions in Context: Past, Present, and Future. Clinical Psychology: Science and Practice, 10(2), 144-156.

http://doi.org/10.1093/clipsy/bpg016

Maslach, C., Schaufeli, W. B., \& Leiter, M. P. (2001). Job burnout. Annual Review of Psychology, 52, 397-422. http://doi.org/10.1146/annurev.psych.52.1.397

Meece, J. L., \& Eccles, J. S. (2010). Handbook of research on schools, schooling, and human development. New York: Routledge.

Meiklejohn, J. et al. (2012). Integrating Mindfulness Training into K-12 education: Fostering the resilience of teachers and students. Mindfulness, 3(4), 291-307. http://doi.org/10.1007/s12671-012-0094-5

Napoli, M., Krech, P., \& Holley, L. (2005). Mindfulness training for elementary school students: The attention academy. Journal of Applied School Psychology, 21(1), 99-125. http://doi.org/10.1300/J370v21n01_05

Roeser, R. W., Schonert-Reichl, K. A., Jha, A., Cullen, M., Wallace, L., Wilensky, R., Oberle, E., \& Thomson, K. (2013). Mindfulness training and reductions in teacher stress and burnout: results from two randomized, waitlist-control field trials. Journal of Educational Psychology, 105(3), 787-804. http://doi.org/10.1037/a0032093

Taylor, C., Harrison, J., Haimovitz, K., Oberle, E., Thomson, K., Schonert-Reichl, K., \& Roeser, R. W. (2015). Examining ways that a mindfulness-based intervention reduces stress in public school teachers: a mixed-methods study. Mindfulness, 7(1), 115-129. http://doi.org/10.1007/s12671-015-0425-4

Teasdale, J. D., Segal, Z. V., \& Williams, J. M. G. (1995). How does cognitive therapy prevent depressive relapse and why should attentional control (mindfulness) training help? Behavior Research and Therapy, 33(1), 25-39. http://doi.org/10.1016/00057967(94)e0011-7

\section{Korespondující autor}

Mgr. Alexander Loziak

Slovenská akadémia vied, Spoločenskovedný ústav, Košice

Karpatská 5, 04001 Košice

loziak@saske.sk 


\title{
Sense of meaningfulness of work and satisfaction of grammar school teachers
}

\section{Smysluplnost práce a spokojenost učitelů gymnázií}

Karel Paulík

${ }^{1}$ Ostravská univerzita, Ostrava, Česká republika

\begin{abstract}
Objective. The aim of the paper is to analyze the relationship between the work satisfaction of the grammar school teachers and perceptions of the meaningfulness of their own work, ie phenomena that are based on the evaluation of work and working conditions and can be assumed to be related to working behavior. The influence of the personality features included in the Big Five five-factor model is also monitored.
\end{abstract}

Method. The research was carried out at the grammar schools in Olomouc and MoravianSilesian Region with the participation of 169 teachers using questionnaire methods such as pencil and paper (questionnaire of life satisfaction DŽS, inventory of work meaningfulness WAMI and NEO FFI personality questionnaire).

Results. The obtained data were evaluated using correlation and regression analysis. Achieved results suggest that work satisfaction and work meaningfulness is positively related to work sense, personality traits, exztraversion, agreeablesness and conscientiousness, and negative to neuroticism. In a relationship with work satisfaction, the sense of meaningfulness of work comes out as a predictor along with satisfaction with financial situation and leisure time.

Conclusion. The results achieved correspond to expectations based on the theoretical knowledge and the results of further research.

Limitations. wider generalization of achieved results is limited the shortcomings of the used methodology.

Keywords. work meaningfulness; work satisfaction; personality; Big Five

https://doi.org/10.5817/CZ.MUNI.P210-9488-2019-20 


\begin{abstract}
Abstrakt
Cíl. Cílem př́spěvku je analýza pracovní spokojenosti učitelì gymnázii v souvislosti s jejich percepci smysluplnosti vlastní práce. Jde tedy o fenomény, které jsou založeny na hodnocení práce a pracovních podmínek a lze u nich predpokládat souvislost s pracovním chováním. Přitom je sledován také vliv osobnostnich vlastností zahrnutých v pětifaktorovém modelu Big Five.

Metoda. Výzkum byl realizován na gymnáziích v Olomouckém a Moravskoslezském kraji za účasti 169 učiteli s využitím dotaznikových metod typu tužka - papír (dotazník životní spokojenosti DŽS, inventár pracovni smysluplnosti WAMI, osobnostni dotazník NEO FFI). Výsledky. Ziskaná data byla vyhodnocena s využitím korelační a regresní analýzy. Dosažené výsledky naznačují, že pracovní spokojenost i smysluplnost práce souvisí pozitivně s pracovní smysluplností, osobnostními vlastnostmi extraverzí, př́větivostí a svědomitostí a negativně s neuroticismem. V relaci s pracovni spokojeností vystupuje pocit smysluplnosti práce spolu se spokojeností s finanční situací a volným časem jako její prediktor.
\end{abstract}

Závěr. dosažené výsledky odpovidaji očekáváním opřeným o teoretické poznatky i výsledky dalšich výzkumů.

Limity. Širší generalizaci dosažených výsledki limitují nedostatky použité metodiky.

Klíčová slova. pracovní smysluplnost; pracovní spokojenost; osobnost; Big Five

\title{
Úvod
}

Cílem našeho příspěvku je analýza pracovní spokojenosti učitelů gymnázií v souvislosti $\mathrm{s}$ jejich percepcí smysluplnosti vlastní práce. V tomto vztahovém rámci zde věnujeme pozornost zejména osobnostním vlastnostem a věku učitelů. Nároky spojené výkonem učitelské profese jsou všeobecně považovány za vysoké a nežrídka vyžadují od učitelů vysoké pracovní nasazení vyplývající mimo jiné z očekávání žáků nadřízených, rodičů i veřejnosti vůbec. Přitom veřejnost chování učitelů více méně pozorně sleduje a práce učitelů bývá nezřídka podrobována kritice, která se nezř́ídka týká i toho, co učitelé sami (např. díky nedostatečné spolupráci rodiny žáka, legislativním omezením apod.) přímo ani nemohou ovlivnit. K naplnění očekávání veřejnosti souvisejících se společenským významem učitele jako zásadního činitele ve výchově nové generace potřebují učitelé určité subjektivní i subjektivní předpoklady. Ze subjektivního hlediska lze považovat za důležité zejména to, do jak míry učitelé považují svou práci za smysluplnou a uspokojující. Pracovní spokojenost i smysluplnost spojené se subjektivním hodnocením vlastní práce se promítají do pracovního chování i do ekonomických výsledků organizace i společnosti. Z jejich podstaty plyne, pravděpodobné vzájemné propojení i souvislost s komplexnějším fenoménem osobnost zahrnujícím mimo jiné individuální charakteristiky ovlivňující pracovní chování i prožívání v daných podmínkách. Problematika pracovní spokojenosti a smysluplnosti práce vůbec se dostává do popředí zájmu věd o práci v souvislostí s orientací na její humanistické a existenciální aspekty, doplňující dříve preferovaný akcent na byrokratické momenty práce (srovnej Paulík, Novotný, Bláha, Horváthová, \& Mikušová, 2014). 
Pracovní spokojenost učitelů (srovnej Paulík, 2011) vychází z hodnocení momentální i celkové životní situace jedince. Důležitá je přitom komparace reality s očekáváním opírající se zejména o individuální hodnotový systém. Pracovní spokojenost je součástí životní spokojenosti. Předmětem hodnocení je zde komplex práce a pracovních podmínek vůbec i jejich dílčí stránky. Jevů negativně ovlivňujících pracovní spokojenost učitelů je celá řada (viz např. Řehulka, 2016). Některé z nich (jako nevhodné chování žáků, nejasnost či rozporuplnost učitelské role či pocit nedostatečného ocenění společností včetně platových podmínek atd.) lze považovat za více méně specifické. Spokojenost v učitelské profesi se vzhledem k řadě nároků a četným úskalím a jevům obtěžujícím učitele vůbec se zdá být poměrně dosti vysoká (srovnej Paulík, 2012).

Pracovní smysluplnost, na jejímž vymezení nebylo dosud dosaženo shody, se odvíjí od pocitů (srovnej Isaksen, 2000), že je práce nutnou a užitečnou součástí většího smysluplného celku, že skýtá možnost vytvoření vazby k vykonávané činnosti a pracovnímu prostředí, a také možnost zapojit se do sociálních vztahů na pracovišti včetně starostlivosti o druhé a také přesvědčení, že práce přináší možnost učit se, radost, pocit naplnění, autonomie, zodpovědnosti, hrdosti, svobody apod. Z jevů, s nimiž souvisí smysl práce i pracovní spokojenost, zde věnujeme pozornost zejména věku a osobnostním faktorům.

Pro pracovní spokojenost i smysluplnost jako fenomény vycházející ze subjektivního hodnocení práce a pracovních podmínek jsou důležité jak situační, tak osobnostní faktory (např. Armstrong, 2012; Blatný, Květoň, Jelínek, Šolcová, Zábrodská, Mudrák, \& Machovcová, 2018; Rosso, Dekas, \& Wrzesniewski, 2010 Popelková, Šišková, \& Zat'ková, 2010 a další). Při sledování vlivu osobnostních faktorů uplatňujeme podobně jako mnozí další autoři model osobnosti Big Five, který se snaží postihnout podstatu osobnosti prostřednictvím pěti faktorů (Hřebíčková, 2011). V předchozích výzkumech (srovnej např. Paulík, 2017; Paulík 2018b; Woods \& Sofat, 2013) se ukázaly některé souvislosti osobnostních charakteristik s pracovní spokojeností i hodnocením smysluplnosti vlastní práce. Negativně se v těchto souvislostech projevoval zejména neuroticismus, podstatné pozitivní souvislosti byly shledány u extraverze, svědomitosti i př́větivosti.

Zaměření našeho výzkumu lze konkretizovat prostřednictvím následujících výzkumných otázek:

1. Jak hodnotí sledovaní učitelé na gymnáziích smysl své práce a jaká je úroveň jejich pracovní spokojenosti?

2. Jaké jsou souvislosti vnímání smyslu vlastní práce a pracovní spokojenosti těchto učitelů s jejich věkem?

3. Jak souvisí pracovní spokojenost a hodnocení smyslu práce učitelů gymnázií s jejich osobnostními rysy v pojetí Big Five?

\section{Metodika}

Ve výzkumu jsme pracovali se souborem učitelů gymnázií z Olomouckého a Moravskoslezského kraje získaných ke spolupráci v rámci diplomové práce př́ležitostným výběrem (Ščudlová, 2017). Do souboru byli zařazeni učitelé, kteří po objasnění účelu výzkumu 
projevili ochotu se jej (s vědomím vedení) zúčastnit. Tento soubor je prakticky identický se souborem učitelů využitým v dalším výzkumu (Paulík, 2018a). Učitelé byli osobně požádání o spolupráci při návštěvě škol vybraných studentkou zpracovávající diplomovou práci na základě jejích časových možností a dostupnosti škol. Složení souboru učitelů přibližuje tabulka 1.

Tabulka 1. Charakteristiky výzkumného souboru

\begin{tabular}{cccccc}
\hline & Počet & & \multicolumn{3}{c}{ Průměrný věk/směrodatná odchylka } \\
\hline Muži & Ženy & Celkem & Muži & Ženy & Celkem \\
$62(37 \%)$ & $107(63 \%)$ & 169 & $42,10 / 9,74$ & $43,11 / 10,35$ & $42,81 / 10,12$ \\
\hline
\end{tabular}

Respondenti byly seznámeni súčelem výzkumu a byli požádáni o vyplnění dotazníkových metod typu tužka-papír, s nimiž pracujeme i v dalších studiích. Jejich popis jsme s drobnými úpravami převzali z našeho textu (Paulík, 2017, s. 14-15).

1. Škála pracovní smysluplnosti Work Meaning Inventory - WAMI (Steger, Dik \& Duffy, 2012). Česká mutace byla ověřena zpětným překladem. Respondenti se vyjadřovali, $\mathrm{k}$ 10 výrokům týkajících se vlastní práce na pětibodové škále (od 1 = vůbec neplatí po 5 = zcela platí). Rozmezí hodnot celkového skóre je 10 až 50. Autoři škály uvádějí dostatečnou konstruktovou, predikční a diskriminační validitu i vnitřní konzistenci. V našich předchozích výzkumech (Paulík, 2016; 2017; 2018b) se hodnota Cronbachovy alfy pro tuto škálu pohybovala vesměs nad 0,8 .

2. Dotazník životní spokojenosti - DŽS (Fahrenberg, Myrtek, Schumacher, \& Brähler, 2001). Metoda přeložená do češtiny a standardizovaná $\mathrm{s}$ ověřenou validitou a reliabilitou. Dotazník je sestaven ze 70 položek, které postihují spokojenost pomocí sedmibodových škál (od 1 = úplná nespokojenost po 7 = silná spokojenost), v deseti různých oblastech života: /1/ zdraví, /2/ práce a zaměstnání, /3/ finanční situace, /4/ volný čas, /5/ manželství a partnerství, /6/ děti, /7/ vlastní osoba, /8/ sexualita, /9/ přátelé známí, př́buzní a /10/ bydlení. Každá oblast je sycena 7 položkami. Do celkového skóre se započítává 7 z 10 škál. Rozpětí celkového skóre je tedy od 49 do 343 . V našich výzkumech (např. Paulík, 2016; 2017; 2018b) hodnota Cronbachovy alfy pro celkovou životní spokojenost i pro všechny subškály vždy přesahovala 0.7 .

3. Osobnostní dotazník NEO Five Factors Inventory - NEO FFI upravený a standardizovaný pro českou populaci (Hřebíčková \& Urbánek, 2001. Obsahuje 60 položek zachycujících faktory Big Five (neuroticism, extraversion, openness to experience, agreeableness; conscietiousness). Každý faktor je postižen 12 položkami hodnocenými na pětibodových škálách (od $0=$ vủbec nevystihuje po 4 = úplně vystihuje). Rozmezí hodnot celkového skóre pro jednotlivé faktory je 0 až 48 . Reliabilita jednotlivých škál (Hřebíčková 2011) se pohybuje od 0.67 po 0.81 . Konstruktová, konvergentní a diskriminační validita byla ověřena pomocí srovnání sebeposuzování a externího hodnocení a srovnáváním měření určitého rysu různými metodami. 


\section{Výsledky}

Tabulka 2. Deskriptivní charakteristiky sledovaných proměnných

\begin{tabular}{lrrrc}
\hline & $N$ & $M$ & $S D$ & $\alpha$ \\
\hline Neuroticismus & 169 & 19,68 & 7,44 & 0,81 \\
Extraverze & 169 & 30,60 & 7,32 & 0,86 \\
Otevřenost zkušenosti & 169 & 27,48 & 6,84 & 0,71 \\
Přívětivost & 169 & 33,12 & 5,16 & 0,67 \\
Svědomitost & 169 & 34,32 & 5,40 & 0,76 \\
Pracovní smysluplnost & 169 & 38,20 & 6,70 & 0,90 \\
Celková spokojenost & 169 & 265,04 & 45,50 & 0,96 \\
Spokojenost se zdravím & 169 & 35,42 & 6,58 & 0,84 \\
Spokojenost s prací a zaměstnáním & 169 & 36,05 & 7,42 & 0,89 \\
Spokojenost s finanční situací & 168 & 30,73 & 8,05 & 0,93 \\
Spokojenost s volným časem & 169 & 36,61 & 7,28 & 0,92 \\
Spokojenost s manželstvím a partnerstvím & 151 & 38,64 & 7,84 & 0,94 \\
Spokojenost se vztah k vlastním dětem & 119 & 41,30 & 5,74 & 0,89 \\
Spokojenost s vlastní osobou & 168 & 35,84 & 6,02 & 0,92 \\
Spokojenost se sexualitou & 160 & 35,49 & 6,79 & 0,92 \\
Spokojenost s př́teli a známými & 167 & 37,59 & 5,60 & 0,87 \\
Spokojenost s bydlením & 167 & 38,64 & 6,23 & 0,83 \\
\hline
\end{tabular}

Ad výzkumná otázka 1) hodnocení pracovní spokojenosti, jehož průměr u našeho souboru byl 5,21 ze 7 možných (74,43\% maxima), napovídá na spíše vyšší hodnotu. To lze říci také o celkové životní spokojenosti našich respondentů, když př́islušné skóre bylo 265,03 z 343, což je 77,27\% maxima. Podobně vyznělo hodnocení smyslu vlastní práce, kde dosažená průměrná hodnota na pětibodové škále inventáře smysluplnosti práce (WAMI) byla $3.82 \mathrm{z}$ možných 5 (76,40\% maxima).

Ad výzkumná otázka 2) korelace pracovní spokojenosti a smysluplnosti s věkem nebyly významné.

Ad výzkumná otázka 3) pracovní spokojenost korelovala statisticky významně s pracovní smysluplnosti $(\mathrm{r}=0,63 \mathrm{p}<0,001)$ a stejně jako pracovní smysluplnost se všemi faktory Big Five s výjimkou otevřenosti zkušenost. Významné korelace pracovní spokojenosti byly také s dalšími součástmi životní spokojenosti zjišt’ovanými DŽS. Pracovní smysluplnost rovněž statisticky významně souvisela se složkami životní spokojenosti kromě spokojenosti s vlastním zdravím. 
Tabulka 3. Korelace sledovaných promènných

\begin{tabular}{lcc}
\hline & Pracovní spokojenost & Pracovní smysluplnost \\
\hline Neuroticismus &,$- 25^{* *}$ &,$- 31^{* *}$ \\
Extraverze &, $38^{* *}$ &, $39^{* *}$ \\
Otevřenost zkušenosti &, $04^{* *}$ &, $10^{*}$ \\
Př́větivost &, $18^{*}$ &, $18^{*}$ \\
Svědomitost &, $30^{* *}$ &, $29^{* *}$ \\
Věk & $.12^{* *}$ &,$- 01^{*}$ \\
Spokojenost s vlastním zdravím &, $27^{* *}$ &, $13^{* *}$ \\
Spokojenost s financemi &, $55^{* *}$ &, $30^{* *}$ \\
Spokojenost s volným časem &, $47^{* *}$ &, $27^{* *}$ \\
Spokojenost s manželstvím a partnerstvím &, $28^{* *}$ &, $34^{* *}$ \\
Spokojenost se vztahem k vlastním dětem &, $30^{* *}$ &, $\left.31^{* *}\right)$ \\
Spokojenost s vlastní osobou &, $53^{* *}$ &, $44^{* *}$ \\
Spokojenost se sexualitou &, $29^{* *}$ &, $24^{* *}$ \\
Spokojenost s přáteli, známými, př́buznými &, $34^{* *}$ &, $31^{* *}$ \\
Spokojenost s bydlením &, $30^{* *}$ &, $18^{* *}$ \\
\hline
\end{tabular}

Poznámka. * hladina významnosti $\mathrm{p}<0,05 ; \quad$ ** hladina významnosti $\mathrm{p}<0,01$

K identifikaci nejlepších prediktorů pracovní spokojenosti z osobnostních vlastností, věku, pracovní smysluplnosti a dalších složek životní spokojenosti byla provedena regresních analýza. Pro její uplatnění soubor splňuje př́íslušné předpoklady (lineární vztah mezi prediktory a závisle proměnnou, shodný rozptyl závisle proměnné pro různé úrovně prediktorů /homoskedascita/ a přibližně normální rozdělení reziduí). $Z$ analýzy byly vyloučeny odpovědi respondentů, u kterých nebyla data analyzovaných proměnných úplná. Do lineární regrese s pracovní spokojeností jako závisle proměnnou byly jako prediktory zadány: věk, pohlaví $(0$ = muž; 1 = žena), hopdnota pracovní smysluplnosti, jednotlivé škály NEO-FFI a DŽS. Model byl statisticky signifikantní $\left[F_{(7 ; 102)}=15,16, p<0,001\right]$ a vysvětloval přibližně $51 \%$ rozptylu $\left[R^{2}=0,510\right.$; Steinovo $\left.R^{2}=0,434\right]$. Statisticky významné prediktory pracovní spokojenosti byly pracovní smysluplnost, spokojenost s finanční situací a volným časem. Parametry tohoto modelu zachycuje tabulka 4.

Tabulka 4. Lineární regrese s pracovni spokojeností jako závisle proměnnou

\begin{tabular}{|c|c|c|c|c|c|c|}
\hline & \multirow{2}{*}{$B$} & \multicolumn{2}{|c|}{$95 \%$ CI pro $b$} & \multirow{2}{*}{$S E_{b}$} & \multirow{2}{*}{$\beta$} & \multirow[b]{2}{*}{$p$} \\
\hline & & spodní & vrchní & & & \\
\hline konstanta & 0,258 & $-0,887$ & 1,425 & 0,543 & & 0,635 \\
\hline Spokojenost s financemi & 0,298 & 0,134 & 0,459 & 0,071 & 0,319 & $<0,001$ \\
\hline Spokojenost s volným časem & 0,069 & $-0,106$ & 0,246 & 0,081 & 0,064 & 0,005 \\
\hline Pracovní smysluplnost & 0,590 & 0,318 & 0,868 & 0,125 & 0,360 & $<0,001$ \\
\hline
\end{tabular}




\section{Diskuse}

Pracovní spokojenost a pocit smyslu vlastní práce u našeho souboru učitelů lze hodnotit jako mírně zvýšené podobně jako v dalších výzkumech (napřs. Paulík, 2016; 2017). O vztazích pracovní smysluplnosti a pracovní spokojenosti se zmiňuje řada autorů. Často uvádějí, že vnímání vlastní práce jako smysluplné se promítá do vyšší spokojenosti a pozitivního vztahu k práci vůbec (viz např. Alacron \& Lyons, 2011; Steger, Dik, \& Duffy, 2012 a další). Tento výzkum předpoklad existence takového vztahu podporuje i u učitelů gymnázií podobně jako naše předchozí výzkumy zaměřené na učitele základních a středních škol (Paulík, 2017). Výše korelací mezi pracovní spokojeností a smysluplností (nízká, respektive střední) svědčí o tom, že je ovlivňován ještě dalšími faktory.

Analýza relací pracovní smysluplnosti a pracovní spokojenosti dotázaných učitelů $\mathrm{s}$ jejich osobnostními vlastnostmi, tedy souvislostí, které jsou $\mathrm{v}$ odborném písemnictví zmiňovány poměrně často (např. Armstrong; 2012; Blatný et al., 2018; Paulík, 2016; Popelková, Šišková, \& Zat'ková, 2010, Steger, Dik, \& Duffy, 2012; Woods \& Sofat, 2013 a další), ukazuje, že u sledovaného souboru učitelů byly patrné souvislosti pracovní spokojenosti i pracovní smysluplnosti se všemi faktory pětifaktorového modelu s výjimkou otevřenosti zkušenostem. Čili zvyšující se pocit pracovní smysluplnosti a spokojenosti souvisí se snižováním neuroticismu a nárůstem extraverze, svědomitosti a př́větivosti. Korelace potvrzující tyto souvislosti vzhledem k povaze učitelského povolání vcelku plausibilní, nelze přeceňovat. Příslušné koeficienty nepřesahují střední sílu vztahu, takže je zde potřeba počítat i $\mathrm{s}$ pravděpodobným uplatněním $\mathrm{i}$ dalších vlivů. $\mathrm{K}$ ověření některých $\mathrm{z}$ nich jsme provedli regresní analýzu s pracovní spokojeností jako závisle proměnnou. Jako prediktory byly zadány věk, pohlaví, míra smysluplnosti práce, faktory Big Five a zbývající jednotlivé oblasti zjišt’ované DŽS (spokojenost se zdravím, finanční situací, volným časem, manželstvím a partnerstvím, vlastními dětmi, vlastní osobou, sexualitou, přáteli známými, př́íbuznými a bydlením). Významnými prediktory pracovní spokojenosti byly pracovní smysluplnost, spokojenost s finanční situací a spokojenost s volným časem. Pokud jde o věk, v našem výzkumu jsme (podobně jako v dalším výzkumu - Paulík, 2017) na rozdíl od autorů předpokládajících jejich zvyšování s věkem (např. Steger, Dik, \& Duffy, 2012) nezjistili významné souvislosti s pracovní spokojeností ani vnímáním smyslu vlastní práce.

\section{Závěr}

Na základě našeho výzkumu u souboru učitelů gymnázií lze podpořit předpoklad, že učitelé gymnázií mají tendenci považovat svou práci spíše za smysluplnou a jsou s ní spíše spokojeni. Jejich pracovní spokojenost souvisí vedle pracovní smysluplnost s dalšími součástmi životní spokojenosti, osobnostními faktory extraverzí, př́větivostí, svědomitostí a (negativní) s neuroticismem. Jako prediktory pracovní spokojenosti se ukázaly pracovní smysluplnost a spokojenost s finanční situací a volným časem. Zjišt'ování hodnot sledovaných proměnných a jejich psychologických souvislostí u učitelů v konkrétních podmínkách i v obecném smyslu má nesporný význam pro praxi při nejmenším vzhledem $\mathrm{k}$ tomu, že se promítají do subjektivního prožívání a do pracovního chování. 


\section{Limity výzkumu}

Možnost zobecnění výsledků limituje zvolená metodika založená na dotazníkovém šetření i skutečnost, že jsme neměli reprezentativní soubor učitelů. Úroveň a detaily zjištěných souvislostí bude vhodné ověřovat v dalších výzkumech.

\section{Literatura}

Alacron, G. M., \& Lyons, J. B. (2011). The relationship of engagement and job satisfaction in working samples. The Journal of Psychology, 145(5), 463-480. https://doi.org/10.1080/00223980.2011.584083

Armstrong, M. (2012). Armstrong's handbook of human resource management practice (12th ed.). London: Kogan Page.

Blatný, M., Květoň, P., Jelínek, M., Šolcová, I., Zábrodská, K., Mudrák, J., \& Machovcová, K. (2018). The influence of personality traits on life satisfaction through work engagement and job satisfaction among academic fakulty members. Studia Psychologica, 60(4), 274 286. https://doi.org/10.21909/sp.2018.04.767

Fahrenberg, J, Myrtek, M., Schumacher, J., \& Brähler, E. (2001). Dotazník životní spokojenosti DŽS. Praha: Testcentrum.

Hřebíčková, M. (2011). Pětifaktorový model v psychologii osobnosti. Př́stupy, diagnostika, uplatnění. Praha: Grada.

Hřebíčková. M., \& Urbánek. T. (2001). NEO pětifaktorový osobnostní inventár (podle NEO Five-Factor Inventory P. T. Costy a R. R. McCraee). Praha: Testcentrum.

Isaksen, J. (2000). Constructing meaning despite the drudgery of repetitive work. Journal of Humanistic Psychology, 40, 84-107. https://doi.org/10.1177/0022167800403008

Paulík, K. (2011) Učitelé v závěru pracovní kariéry a pracovní spokojenost. In B. Lazarová (Ed.). Pozdní sběr. O práci zkušených učitelů. (pp. 83-98). Brno: Paido.

Paulík, K. (2012). Job satisfaction and stress among teachers. New Educational Review, $30(4), 138-149$.

Paulík, K. (2016). Smysluplnost práce, životní spokojenost a osobnost. In: K. Millová, A. Slezáčková, P. Humpolíček, \& M. Svoboda (Eds.). Sociální procesy a osobnost 2015. Otázky a výzvy. Sborník př́spěvků. 9. až 11. záři 2015 (pp. 276-281). Brno: Masarykova univerzita.

Paulík. K. (2017). Některé psychologické souvislosti hodnocení smyslu vlastní práce učiteli. Studia Paedagogica, 22(3). 9-24. https://doi.org/10.5817/SP2017-3-2

Paulík, K. (2018a). Osobnost a smysl práce učitelů gymnázií. Předneseno na konferenci Sociálne procesy a osobnost' 2018. Stará Lesná 17.-19. 9. 2018. 
Paulík, K. (2018b). Osobnostní vlastnosti a subjektivní hodnocení práce. In M. Blatný, M. Jelínek P. Květon, D. Vobořil (Eds.) Sociální procesy a osobnost, 2017, Sborník př́spěvkủ mezinárodni konference 18. - 20. zář́ 2017 (pp. 266-270). Brno: Psychologický ústav AV ČR.

Paulík, K., Novotný, J. S., Bláha, J., Horváthová, P., \& Mikušová, M. ( 2014). Psychologické souvislosti pracovní smysluplnosti. Psychologie a její kontexty, 5(2), 3-15.

Popelková, M., Šišková, A., \& Zat'ková, M. (2010). Životná spokojnost a vybrané osobnostné premenné učitel'ov. Psychologie a jeji kontexty, 1(1), 15-31.

Rosso, B. D., Dekas, K. H., \& Wrzesniewski, A. (2010). On the meaning of work: A theoretical integration and review. Research in Organizational Behavior, 30, 91-127. https://doi.org/10.1016/j.riob.2010.09.001

Řehulka, E. (2016). Zdraví-učitelé-škola. Brno: Masarykova univerzita.

Steger, M. F., Dik, B. J., \& Duffy, R. D. (2012). Measuring meaningful work: the work and meaning inventory (WAMI). Journal of Career Assessment, 20, 322-337. https://doi.org/10.1177/1069072711436160

Ščudlová, S. (2017). Pracovni angažovanost a spokojenost učitelů [Master thesis]. Ostravská univerzita, Ostrava, Česká republika.

Woods, S. A., \& Sofat, J. A. (2013). Personality and engagement at work: the mediating role of psychological meaningfulniess. Journal of Applied Social Psychology, 43, 2203-2210. https://doi.org/10.1111/jasp.12171

\section{Korespondující autor}

prof. PhDr. Karel Paulík, CSc.

University of Ostrava, Faculty of Arts, Department of Psychology

Reální 5, 70103 Ostrava, Czech Republic

karel.paulik@osu.cz 


\title{
Leadership in Education - Characteristics of the Key Concepts
}

\section{Líderšip v edukácii - charakteristika kl’účových konceptov}

Eva Sollárovál, Vladimír Poliach ${ }^{1}$, Lucia Paškovál, Zuzana Heinzovál, Beata ŽitniakováGurgovál

${ }^{1}$ Matej Bel University, Banská Bystrica, Slovakia

\begin{abstract}
Objectives. Education and development of "leaders in education" in the Slovak Republic is not sufficiently grounded, theoretically or empirically. Within these circumstances the APVV project no. 17-0557 ("Psychological approach to development, implementation and evaluation of the competence model of educational leaders' development") has an ambition to contribute. As a precondition of a theoretically grounded competence model, there is a need to understand and define key concepts of leadership as applied to the educational setting which is the aim of the paper.
\end{abstract}

Method. The method of the Frame Analysis by Ritchie \& Spencer (1994) using CAQDAS and multiple evaluations, was applied to selected representative international literature sources from the area of leadership in education dated 2002 to 2018.

Results. The sources analyzed are of high thematic and methodological variance. Defining leadership in education can be categorized according to the key concepts of school, educational and teacher leadership, which is discussed together with related concepts identified as well as the psychological knowledge of leadership applied in the educational setting.

Conclusions. Specifications of the key concepts in leadership in the education setting seems inspirational for further processing of the project, as well as areas or topics identified where psychological knowledge and research findings seem to be insufficiently applied.

Limitations. Narrowing the focus on the North American context as other studies (eg European) will follow.

Keywords. school leadership; educational leadership; rapid review; framework analysis

https://doi.org/10.5817/CZ.MUNI.P210-9488-2019-21 


\begin{abstract}
Abstrakt
Ciel'e. Vzdelávanie a podpora lídrov v edukácii $v$ SR nie sú dostatočne teoreticky a empiricky ukotvené. V týchto súvislostiach má ambíciu prispiet' projekt APVV-17-0557 "Psychologický pristup $k$ tvorbe, implementácii a overovaniu kompetenčného modelu rozvoja lídrov $v$ edukácii". Predpokladom koncipovania teoreticky ukotveného kompetenčného modelu je aj východiskové uchopenie a definovanie klúčových konceptov oblasti lideršipu aplikovaného do edukačného kontextu, čo predstavuje hlavný ciel' príspevku.
\end{abstract}

Metóda. Na vybraných reprezentatívnych medzinárodných zdrojoch z oblasti líderšipu v edukačnom prostredí z obdobia rokov 2002 až 2018 bola aplikovaná metóda Rámcovej analýzy (Ritchie \& Spencer) s využitím CAQDAS a zapojením viacerých posudzovatel'ov.

Výsledky. Analyzované zdroje majú vysokú tematickú $i$ metodologickú variabilitu. Vymedzovanie líderšipu v edukácii sa dá kategorizovat' podl'a klúčových konceptov školského, edukačného a učitel'ského líderšipu, čo je v príspevku diskutované spolu so súvisiacimi konceptmi v oblasti, ako aj mierou zastúpenia psychologického poznania témy líderšipu.

Závery. Potenciálne podnetné sa javi porovnanie charakteristík konceptov školského a edukačného líderšipu, ako aj identifikovanie tém nedostatočne ukotvených v psychologickej teórii a výskume.

Limity. Zúženie záberu na severoamerický kontext, ked’že iným (napr. európskemu) sa budú venovat' d'alšie štúdie.

Kl’účové slová. školský líderšip; edukačný líderšip; rýchly prehl’ad; rámcová analýza

\title{
Úvod
}

Líderstvo je jedným z najskúmanejších fenoménov v sociálnych vedách a zo získaných poznatkov čerpá aj školstvo. Analytický nástroj Google Trends prináša dôkaz o tom, že téma vzdelávania $\mathrm{v}$ spojení s pojmom líderšip je od roku 2004 po súčasnost' jednou z najvyhl'adávanejších. Výraz „school leadership“ je na 4. mieste po spojeniach s výrazmi „management“, „leadership management“ a „leadership quotes“. To odráža trend, ktorému čelia všetky krajiny sveta - potrebu prispôsobit’ svoje vzdelávacie systémy súčasnosti.

Správa OECD „Improving School Leadership - policy and practice“ (Pont, Nusche, \& Moorman, 2008/OECD) konštatuje, že tvorcovia politík musia udržatel'ným spôsobom zvýšit' kvalitu výsledkov škôl. Klúčom k tomu je podl’a mnohých štúdií práve líderstvo v edukácii ako celosvetová priorita vzdelávacej politiky (Schleicher, 2015/OECD).

„School leadership“ je konceptom, ktorý v poslednom čase prit'ahuje pozornost' v diskusiách k transformácii školstva. Leithwood a Riehl (2009, s. 20) ho navrhujú definovat' ako „prácu zameranú na mobilizovanie a ovplyvňovanie druhých s ciel'om artikulovat' a dosiahnut' zdiel'ané ciele a zámery školy“, pričom ciel'ovú skupinu predstavuje manažment školy. Ďalší prístup, označovaný ako „educational/teacher leadership“, zahŕňa, prípadne samostatne vyčleňuje aj učitel'ov ako aktérov inovovania školského prostredia a klímy podporujúcej spoluprácu (napr. Moureira, 2006). Ujasnenie všetkých týchto pojmov je pre náš 
projekt dôležité, pretože sa následne premietne do vymedzení štandardových modelov, ktoré vytvoria bázu pre návrh vzdelávacích programov.

Hlavným ciel'om príspevku je prispiet' k vymedzeniu konceptu „líderstvo v edukácii“ v kontexte (a) poznania podobností a rozdielov termínov „educational/teacher leadership“ a „school leadership“; (b) ich rozšírenia o d’alšie súvisiace koncepty; a (c) inventarizácie ich psychologickej dimenzie. K tomu formulujeme nasledujúce výskumné otázky:

VO1: Je vymedzenie pojmov ,school leadership“ a ,educational/teacher leadership " v literatúre dostatočne jasne diferencované?

VO2: Aké d’alšie súvisiace pojmy špecifikujú oblast' líderšipu v edukácii?

VO3: Do akej miery sa v literatúre v aplikácii líderšipu do edukačného kontextu uplatňuje psychologická perspektíva a poznanie?

Terminologická rozmanitost' využitých dokumentov v tejto etape výskumu neumožňuje stabilizovat' prekladatel'ské konvencie. Striedanie termínov "leadership", "líderstvo", "líderšip" nechce rozlišovat' významové odtiene, hoci prekladmi "líderstvo" a "líderšip" priznávame dominanciu anglosaských zdrojov. Ťažisko významových rozlíšení odporúčame hl'adat' v kombinácii s rôznymi adjektívami, vymedzujúcimi odlišné konštrukty.

\section{Metódy}

\section{Dizajn štúdie a metodika}

Táto prehl'adová štúdia je súčast'ou úvodnej konceptualizačnej etapy výskumu s ciel'om vybudovat' čo najvýstižnejší terminologický rámec projektu. Výskumné zámery aplikačného projektu však nepotrebujú systematický prehl'ad. Preto sme zvolili kombináciu Hendlom (2016) zmieňovaných metód Rýchleho prehl'adu (Khangura et al., 2012) a Rámcovej analýzy (framework analysis, Ritchie \& Spencer, 1994). Autorky Rámcovej analýzy navrhujú na vytváranie rýchlych prehladov postup: (1) Oboznámenie sa s materiálom; (2) identifikovanie tematického rámca; (3) indexovanie dát; (4) tvorba diagramov alebo tabuliek (,,charting“); (5) mapovanie a interpretácia, v rámci ktorej sa definujú koncepty, tvoria typológie, hladajú asociácie a navrhujú explanácie (Ritchie \& Spencer, 1994, s.178-194). Ambíciou rýchlych prehl'adov nie je vyčerpávajúce pokrytie všetkých zdrojov, skôr ich reprezentatívna vzorka.

Rámcovú analýzu sme realizovali CAQDAS softvérom Atlas.ti (verzia 7), určeného na kvalitatívne spracovanie dát, t.j. na ich indexovanie, kategorizáciu, reorganizáciu, triedenie, vizualizáciu a analýzu prostredníctvom jazyka SQL. Krok (1) oboznámenie sa s materiálom spočíval v úvodnom bookmarkovaní dokumentov a orientačnom prieskume úvodov kapitol. Krok (2) identifikovanie tematického rámca predstavovalo prvé triedenie dokumentov z hl'adiska relevantnosti voči pojmom „educational leadership“ a „school leadership“ a náčrt stratégie tvorby indexov. Krok (3) indexovanie (v Atlase kódovanie) sa skladal z niekol'kých priechodov všetkými textami a postupným vývojom kódovacieho systému (označili sme 1130 úryvkov textu a aplikovali 284 kódov). Krok (4) tvorba diagramov spočíval v redukcii kategórií a krok (5) mapovanie a interpretácia v ich zužitkovaní vo vzt’ahu k ciel’om štúdie. 


\section{Analyzovaný súbor}

Skúmanú populáciu tvorili dokumenty z oblasti praxe a výskumu líderstva v edukácii. Pri tvorbe vzorky sme použili sampling, označovaný ako teoretický výber, presnejšie vzorkovanie na základe konštruktu. Kvôli redukcii rizika prehliadnutia zásadných zdrojov sme kombinovali aktuálne diela so súhrnnými publikáciami z minulosti podla týchto kritérií: (1) Dokumenty s ambíciou priniest' reprezentatívny obraz z pohl'adu množstva autorov (typ „handbook“ alebo „encyclopedia“); (2) prehl’adové štúdie danej oblasti (typ „research review“ alebo „metaanalysis“); (3) publikácie, v nejakom ohl’ade presne zodpovedajúce zameraniu nášho projektu. Signálom pre zastavenie samplingu bolo dosiahnutie potrebnej tematickej saturácie a bohatosti (Hendl, 2016). Východiskovú vzorku po všetkých procedúrach napokon tvorí 23 dokumentov v rozsahu vyše 8 tisíc strán, publikovaných v rozpätí 22 rokov a vytvorených takmer výhradne medzinárodnými autorskými tímami, ako uvádza Tabul'ka 1.

Tabul'ka 1. Výber tematicky relevantných zdrojov pre rámcovú analýzu $(n=23)$

\begin{tabular}{|c|c|c|c|c|c|}
\hline No & Skrátený názov & Autor/Editor, Rok & Typ/Prisp & Kap & Str \\
\hline 1 & School Leadership - Beyond Ed.Management & Grace, 1995 & monografia[1] & 12 & 240 \\
\hline 2 & Internat. Handbook of Educational Leadership... & Leithwood et al., 1996 & handbook[45] & 31 & 1172 \\
\hline 3 & Educational Leadership-A Reference Handbook & Williams-Boyd, 2002 & monografia[1] & 7 & 341 \\
\hline 4 & Second Internat. Handbook of Ed. Leadership... & Leithwood et al., 2002 & handbook $[55]$ & 34 & 1246 \\
\hline 5 & Understanding School Leadership & Earley \& Weindling, 2004 & monografia[2] & 14 & 203 \\
\hline 6 & School Leadership that Works & Marzano et al., 2005 & monografia[3] & 7 & 194 \\
\hline 7 & Encyclopedia of Educational Leadership & English, 2006 & encyk1.[317] & $\mathrm{A}-\mathrm{Z}$ & 1086 \\
\hline 8 & OECD - Improving School Leadership & Pont et al., 2008 & zborník[13] & 13 & 452 \\
\hline 9 & Conceptualizing School Leadership and... & Spillane \& Healey, 2010 & článok[2] & 1 & 28 \\
\hline 10 & Emotional Intelligence and Resilience as... & Maulding et al., 2012 & článok[5] & 1 & 29 \\
\hline 11 & School Leadership Effect Revisited - Review ... & Scheerens, 2012 & zborník[5] & 5 & 152 \\
\hline 12 & School Leadership in the Context of Standards... & Volante, 2012 & zborník[14] & 11 & 263 \\
\hline 13 & OECD - Leadership for 21st Century Learning... & Istance et al., 2013 & zborník[16] & 6 & 204 \\
\hline 14 & Modeling School Leadership across Europe.... & Pashiardis, 2014 & & 9 & 203 \\
\hline 15 & The Teacher Leader - Core Competencies and... & Tomal et al., 2014 & monografia[3] & 9 & 192 \\
\hline 16 & Unmasking School Leadership - A Longitudin... & Sugrue, 2015 & monografia[1] & 12 & 302 \\
\hline 17 & A Decade of Research on School Principals... & Ärlestig et al., 2016 & zborník[43] & 25 & 543 \\
\hline 18 & Mindful School Leadership: Guidance from... & Gates \& Gilbert, 2016 & kapitola[2] & 1 & 16 \\
\hline 19 & Competencies in Teaching, Learning and Educ... & Spector et al., 2016 & zborník[59] & 21 & 363 \\
\hline 20 & The Wiley Internat. Handbook of Educational... & Waite \& Bogotch, 2017 & handbook[60] & 24 & 475 \\
\hline 21 & Quandaries of School Leadership - Voice from... & Touchton et al., 2018 & zborník[21] & 13 & 248 \\
\hline 22 & The Nature of School Leadership - Global... & Miller, 2018 & monografia[1] & 9 & 211 \\
\hline \multirow[t]{2}{*}{23} & The Practice of School Middle Leadership & Grootenboer, 2018 & monografia[1] & 9 & 196 \\
\hline & & polu & [675] & 274 & 8359 \\
\hline
\end{tabular}

Vysvetlivky. Typ/Prisp - typ publikácie a počet prispievatel'ov [v hranatej zátvorke], Kap - počet kapitol zdroja (okrem A-Z, čo je encyklopedický zdroj) 


\section{Výsledky a diskusia}

\section{Diferencovanie pojmov „school leadership“ a „educational leadership“(VO1)}

Prvým rozlíšením je pomerne jasné oddiferencovanie pojmu „leadership“ od pojmov „management“, „administration“, resp. „bureaucratic administration“ (napr. Grace, 1995). Zásadné handbooky z nedávnej minulosti (Leithwood et al., 1996, Leithwood \& Hallinger, 2002) síce ešte nesú v názvoch spojenie „Educational Leadership and Administration“, v novších prameňoch je však už zriedkavejšie. Prostredníctvom rámcovej analýzy, v ktorej sme použili tak zdroje americkej, ako i medzinárodnej proveniencie sme sa pokúsili identifikovat' tematicky zretel'né subkategórie líderstva v edukácii. Našli sme ho v 19 z 23 zdrojov. Dospeli sme k rozdeleniu kl'účových konceptov do troch kategórií líderšipu: školský (school), edukačný (educational), a učitel'ský (teacher) líderšip tak, ako to zobrazuje Tabul'ka 2. Pri tejto kategorizácii sme zatial' nezohl'adňovali súvisiace špecifikácie líderšipu (napr. transakčný, transformačný, inštruktážny, kolaboratívny, atd'.)., ale iba ciel'ové skupiny, t.j. hlavne manažment školy a učitel'ov.

Tabul'ka 2. Tri subkategórie , líderstva v edukácii“ identifikované rámcovou analýzou

\begin{tabular}{|c|c|c|c|c|}
\hline No & Názov / Autor & $\begin{array}{l}\text { School } \\
\quad \text { L }\end{array}$ & $\begin{array}{c}\text { Educ } \\
\text { L }\end{array}$ & $\begin{array}{l}\text { Teacher } \\
\quad \text { L }\end{array}$ \\
\hline 1 & Internat. Handbook of Educat. Leadership and Adm. (1996) & $\mathrm{x}$ & & \\
\hline 2 & Educational Leadership - A Reference Handbook (2002) & & $\mathrm{x}$ & $\mathrm{x}$ \\
\hline 3 & Earley, $P \&$ Weindling, D. (2004) & $\mathrm{x}$ & & \\
\hline 4 & Encyclopedia of Educational Leadership and_Vol.2 (2006) & & & $\mathrm{x}$ \\
\hline 5 & $\begin{array}{l}\text { OECD - Improving School Leadership - Vol.1 - Policy and } \\
\text { Practice (2008) }\end{array}$ & $\mathrm{x}$ & & \\
\hline 6 & $\begin{array}{l}\text { OECD - Improving School Leadership - Vol.2 - Case studies } \\
\text { on system leadership (2008) }\end{array}$ & & & $\mathrm{x}$ \\
\hline 7 & Bar-On (2012) & $\mathrm{x}$ & & \\
\hline 8 & Scheerens (2012) & & $\mathrm{x}$ & \\
\hline 9 & Volante (2012) & & & $\mathrm{x}$ \\
\hline 10 & $\begin{array}{l}\text { OECD - Educational Research and Innovation Leadership for } \\
21 \text { st Century Learning (2013) }\end{array}$ & & & $\mathrm{x}$ \\
\hline 11 & Tomal et al. (2014) & & & $\mathrm{x}$ \\
\hline 12 & Pashiardis, P. (2014) & & & $\mathrm{x}$ \\
\hline 13 & Sugrue, C. (2015) & $\mathrm{x}$ & & \\
\hline 14 & Ärlestig et al. (2016) & & $\mathrm{x}$ & \\
\hline 15 & Spector et al. (2016) & $\mathrm{x}$ & & \\
\hline 16 & $\begin{array}{l}\text { The Wiley International Handbook of Educational Leadership } \\
\text { (2017) }\end{array}$ & $\mathrm{x}$ & & \\
\hline 17 & Touchton et al. (2018) & $\mathrm{x}$ & & \\
\hline 18 & Miller (2018) & $\mathrm{x}$ & & \\
\hline 19 & Grootenboer (2018) & & $\mathrm{x}$ & \\
\hline
\end{tabular}

Vysvetlivky. Hoci analyzovaných bolo 23 zdrojov (Tabul'ka 1), tu uvádzame len tých 19, v ktorých sme našli definície a vymedzenia lídrov / líderstva. 
Najjasnejšie vymedzované sú "school leadership", v zmysle riadiacich pracovníkov školy a "teacher leadership", v zmysle učitel'ov. Pojem "educational leadership" je chápaný variabilnejšie (od ekvivalencie so "school leadership" až po prienik s "teacher leadership"). Napríklad: "Pojem ,školský líderšip" je v niektorých vzdelávacích systémoch totožný s významom „školský manažment“ a „riadenie školy (administration)“ (Miller, 2018, s.8). „Líderšip je proces ovplyvňovania, ktorý vedie k dosiahnutiu želaných ciel'ov. Úspešní lídri rozvíjajú víziu svojich škôl založenú na osobných a profesionálnych hodnotách; touto víziou ovplyvňujú svojich kolegov, aby ju zdiel'ali a pod. Líderšip zahŕňa aj inšpirovanie a podporu druhých v smere dosiahnutia vízie školy, ktorá je založená na jasných osobných a profesionálnych hodnotách...“ (Earley \& Weindling, 2004, s. 5). „Edukačný líderšip zdôrazňuje rolu lídrov v posilňovaní a udržiavaní prostredia vyučovania (teaching) a učenia sa (learning) pre všetkých členov školskej komunity..." (Waite \& Bogotch, 2017, s. 239). „Učitel'ský líderšip (teacher leadership) je vo všeobecnosti považovaný za schopnost' a energiu prispiet' k rozvoju školy nad rámec vlastných povinností v triede. Učitel'skí lídri sú tí, ktorí pracujú so svojimi kolegami tak, aby ovplyvnili vzdelávaciu a pedagogickú prax v rámci celej školy..." (English, 2006, s. 583).

Odpoved' na VO1: Analyzované pojmy nie sú optimálne diferencované, vich vymedzovaní však sú určité konvergencie. Najčastejšie sú chápané ako dve nerovnako vel'ké množiny so spoločným prienikom, kde „school leadership“ je niekedy podmnožinou, inokedy samostatnou množinou voči "educational leadership". „Edukačný líder“ naznačuje širší kontext než len riadenie školy a zahŕňa aj lídrov na vyšších stupňoch riadenia. „School leader“ viac zdôrazňuje vyučovanie (teaching) a učenie sa (learning).

\section{Ďalšie súvisiace koncepty (VO2)}

Adjektív, s ktorými sa kombinuje "leadership" sme identifikovali viac ako 60. Niektoré sú používané „ad hoc“ na označenie vlastností („class-cultural“, “collegial“, „,creative“, „operative“, „strong“, „socially just“), iné sú teoreticky fundovanejšie. „Encyclopedia of Educational Leadership...“ (English et al., 2006) bližšie opisuje napr.: „distributed“, „participatory“, „situational“, „,spiritual“", „transformational“, ,system-/task-oriented“.

Obrázok 1. Konštrukt ,, integral school leadership“ (Krüger \& Scheerens, 2012, s.26)

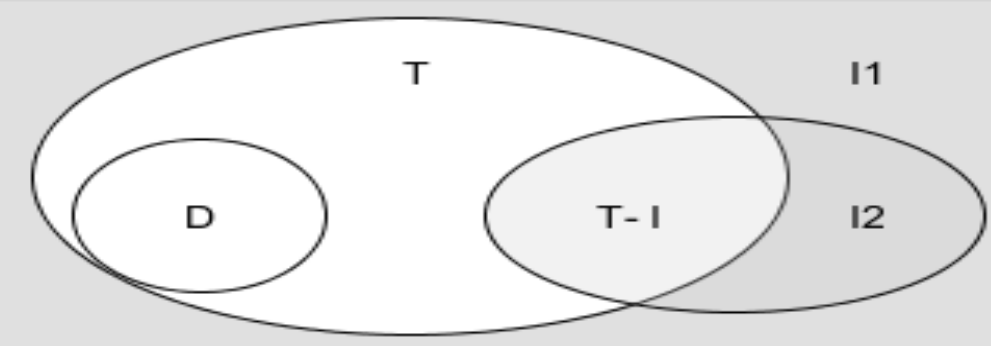

Vysvetlivky: T (biele časti) - „transformational leadership“; D - „distributed leadership“ ako podmnožina T; I1 (sivé časti) - „instructional leadership 1“ širšie chápaný ako smerovanie, stimulácia na úlohu zameranej klímy a manažovanie učeb. programu; I2 - ,instructional leadership 2“ užšie chápaný ako riadenie učebného programu; prienik T-I - vývoj na úlohu orientovanej kultúry; zjednotenie T a I1 - „integral leadership“. 
Kombinačnú nesystematickost' sa pokúsili prekonat' Krüger \& Scheerens (2012) konštruktom "integral school leadership" (Obrázok 1), vychádzajúc z metaanalýz zdrojov Web of Science, ERIC a ERA v časovom rozpätí 1985 až 2005, novších metaanalýzach OECD (17 krajín) a d’alších 25 štúdií z obdobia 2005-2010. Medzi novšie pokusy patrí Millerov (2018) model, definujúci “school leadership” ako: (1) „Personal and internally motivated“; (2) ,policy driven and mediated“; (3) „change oriented“; (4), ,teacher dependent“; (5), ,enterprising and entrepreneurial“; (6) „,context dependent“; (7) ,partnership dependent“".

Odpoved' na VO 2 : Typickými konceptami súvisiacimi so "school / educational leadership" je "transformational", "transactional", "distributed", zatial' čo pre "teacher leadership" je typická väzba na "intructional", "task-oriented" a "innovative". Nachádzame však aj pokusy o vzt’ahové resp. viacdimenzionálne konceptualizácie.

\section{Miera uplatňovania psychologickej perspektívy v edukačnom líderšipe (VO3)}

V rámci 147 najrelevantnejších kapitol sa psychologické témy objavili 41krát, napríklad: (1) International Handbook... (1996) 5x: ,problem solving“, ,,managerial problem processing“, „,values in educational administration“, „organizational learning“, ,psychology of change“. (2) Second International Handbook... (2002) 13x: „lessons from successful leader“, „leadership and self-assessment“, „leadership and cognition“, „distributed leadership“, „team work“, „developing capability“, „models of mind“, „reflective practice“, ,accountability“, „leader formation“, „developing leaders“, „emotions in educational administration“, „the meaning of mentoring“. (3) Understanding School Leadership (2004) 5x: „,characteristics of outstanding leaders“, ,ethically responsible leadership“, „metaphors of leadership“, „,senior leadership“, „developing leaders“. (4) OECD - Improving School Leadership (2008) 3x: „leadership responsibilities“, „leadership skills“, ,accountability“. (5) The Wiley International Handbook... (2017) 4x: „creativity and leadership“, „leadership and emotion“, „decision in leadership“, „motivation of leader“. (6) Quandaries of School Leadership (2018) 7x: „performance of leader“, „expectations of leaders“, ,assessment“, ,emotional intelligence“, „trust building“, „,ognition“, „leadership competencies“. (7) The Nature of School Leadership (2018) 4x: ,personality“, ,,motivation“, ,values“, ,,partnership“.

Odpoved' na VO3: Literatúra o ,školskom/edukačnom líderšipe“ psychologickú tematiku neignoruje, no ani ju nepovažuje za svoje tematické t’ažisko. Oblast' tak určite ponúka značný priestor pre rozširujúci psychologický výskum.

\section{Závery}

Tento rýchly prehl'ad poskytuje podnety a spresňuje našu orientáciu nasledovne:

(1) Rôzne konceptualizácie líderstva v edukácii rozlišujú: (a) líderstvo vzt’ahujúce sa na pracovníkov školy, resp. školstva (school, resp. educational leadership), a (b) líderstvo riadiacich pracovníkov aj učitel’ov súvisiace s vyučovaním a učením sa (teacher leadership).

(2) Frekvencia prívlastkov ukazuje ako pretrvávajúci vplyv “osvedčených” konštruktov (transformational, distributed), inovovaný snahami o systémovejšie chápanie (integral, 
holistic), tak silnejúci záujem o sociálno-psychologickú dimenziu (personal, relational).

(3) Prieskum psychologického potenciálu témy naznačuje viaceré perspektívne rozšírenia, napr. kogníciu, emócie, hodnoty, zdravie atd’.

Za hlavný limit štúdie považujeme dominanciu konceptov z anglosaských zdrojov. Hoci celkový záber je nepochybne internacionálny, rezervy vidíme v hlbšom prieniku do chápania významov líderstva $\mathrm{v}$ iných kultúrach a v kontexte iných edukačných systémov. To je pre nás výzvou pre spracovanie systematickejšieho prehl'adu v tomto smere.

\section{Poznámka}

Na túto štúdiu nadväzuje posledná štúdia z tohto zborníka od Sollárovej et al. Leadership Competency Models within the Educational Setting [Kompetenčné modely liderstva v edukačnom prostredí].

\section{Literatúra}

Ärlestig, H., Day, Ch. \& Johansson, O. (Eds.). (2016). A Decade of Research on Schools Principals. Cham, Switzerland: Springer. http://doi.org/10.1007/978-3-319-23027-6

Earley, P. \& Weindling, D. (2004). Understanding School Leadership. London, UK: $\mathrm{PCP} / \mathrm{SAGE}$.

English, F.W. (Eds) (2006). Encyclopedia of Educational Leadership and Administration (vol. 1, 2). Thousand Oaks, CA: SAGE Publications. http://doi.org/10.4135/9781412939584

Gates, G.S. \& Gilbert, B. (2016). Mindful school leadership. In: K. Schonert-Reichl \& R. Roeser (Eds.), Handbook of mindfulness in education (pp. 99-118). New York, NY: Springer.

Grace, G. (1995). School Leadership: Beyond Education Management. London, UK: Falmer Press.

Grootenboer, P. (2018). The Practices of School Middle Leadership. Singapure: Springer. http://doi.org/10.1007/978-981-13-0768-3 2

Hendl, J. (2016). Kvalitativní výzkum. Základní teorie, metody a aplikace. Portál: Praha.

Khangura, S. et al. (2012). Evidence summaries: the evolution of a rapid review approach. Systematic Reviews, 1(10), 1-9. http://doi.org/10.1186/2046-4053-1-10

Krüger, M. \& Scheerens, J. (2012). School Leadership Effects Revisited: Review and MetaAnalysis of Empirical Studies. Dordrecht, Netherlands: Springer.

Leithwood, K. et al. (Eds.) (1996). International Handbook of Educational Leadership and Administration. Boston, USA: Kluwer Academic Publishers. http://doi.org/10.1007/978$\underline{94-009-1573-2}$ 
Leithwood, K. \& Hallinger, P. (Eds.) (2002). Second International Handbook of Educational Leadership and Administration. Dordrecht, Netherlands: Springer.

http://doi.org/10.1007/978-94-010-0375-9

Marzano, R.J. et al. (2005). School leadership that works: From Research to results. Alexandria, VA: Association for Supervision and Curriculum Development.

Maulding, W., Peters, G. et al. (2012). Emotional intelligence and resilience as predictors of leadership in school administrators. Journal of Leadership Studies, 5(4), 20-29. http://doi.org/10.1002/jls.20240

Miller, P.W. (Ed) (2018). The Nature of School Leadership. Global Practice Perspectives. New York, NY: Palgrave Macmillan. http://doi.org/10.1007/978-3-319-70105-9

Moureira, O. (2006). Dirrección y Eficacia Escolar. Revista Iberoamericana de Educación, $4(4), 1-10$.

OECD (2013). Leadership for 21 st Century Learning, Educational Research and Innovation, OECD Publishing. http://doi.org/10.1787/9789264205406-en

Pashiardis, P. (Ed) (2014). Modeling School Leadership across Europe. Dordrecht, Netherlands: Springer. http://doi.org/10.1007/978-94-007-7290-8

Pont, B., Nusche, D. \& Moorman, H. (2008). Improving School Leadership. Volume 1 \& 2: Policy and Practice. Paris, France: OECD.

Ritchie, J. \& Spencer, L. (1994). Qualitative data analysis for applied policy research. In A. Bryman and R. G. Burgess (Eds.), Analyzing qualitative data (pp. 173-194). London: Routledge. http://doi.org/10.4324/9780203413081 chapter 9

Scheerens, J. (Ed) (2012). School Leadership Effects Revisited. Review and Meta-Analysis of Empirical Studies. Dordrecht, Netherlands: Springer. http://doi.org/10.1007/978-94-007$\underline{2768-7}$

Schleicher, A. (2015). Schools for 21st-Century Learners: Strong Leaders, Confident Teachers, Innovative Approaches, international Summit on the teaching profession, OECD publishing. http://doi.org/10.1787/9789264231191-en

Spector, J., Ifenthaler, D., Sampson, D., \& Isaías, P. (2016). Competencies in Teaching, Learning and Educational Leadership in the Digital Age. Berlin: Springer. http://doi.org/10.1007/978-3-319-30295-9 16

Spillane, J.P. \& Healey, K. (2010). Conceptualizing school leadership and management from a distributed perspective: An exploration of some study operations and measures. Elementary School Journal, 111(2), 253-281. http://doi.org/10.1086/656300

Srivastava, A. \& Thomson, S. (2009). Framework Analysis: A Qualitative Methodology for Applied Policy Research. Journal of Administration and Governance, 4(2), 72-79.

Sugrue, C. (2015). Unmasking School Leadership. A Longitudinal Life History of School Leaders. Dordrecht, Netherlands: Springer. http://doi.org/10.1007/978-94-017-9433-6

Tomal, D.E., Schilling, C.A., \& Wilhite, R.K. (2014). The Teacher Leader: Core 
competencies and strategies for effective leadership. London, UK: Rowman \& Littlefield.

Touchton, D.J., Rodriguez, M.A. et al. (Eds.) (2018). Quandaries of School Leadership. Voices from Principals in The Field. New York, NY: Palgrave Macmillan. https://doi.org/10.1007/978-3-319-59120-9

Volante, L. (Ed.) (2012). School leadership in the context on standards-based reform: International perspectives, volume 16. Dordrecht, Netherlands: Springer. https://doi.org/10.1007/978-94-007-4095-2

Waite, D. \& Bogotch, I. (Eds.) (2017). The Wiley International Handbook of Educational Leadership. Hoboken, USA: John Wiley \& Sons, Inc. https://doi.org/10.1002/9781118956717

Williams-Boyd, P. (2002). Educational Leadership - A Reference Handbook. Santa Barbara, USA: ABC-CLIO.

\section{Korespondující autor}

PaedDr. Lucia Pašková, PhD.

Matej Bel University, Faculty of Education, Department of Psychology

Ružová 13, 97404 Banska Bystrica, Slovak Republic

lucia.paskova@umb.sk 


\title{
Employees' opinions to management in SMEs in the Czech Republic Názory zaměstnanců na management v MSP v České republice
}

\author{
Jana Marie Šafránkovál \& Martin Šikýr $\check{r}^{l}$
}

${ }^{1}$ College of Regional Development and Banking Institute - AMBIS, Czech Republic

\begin{abstract}
Objective. Small and medium-sized enterprises (SMEs) play an important role in economic development and many of them consider management of employees to be the important source for achieving expected goals. Theoretical background is based on characteristic of different management styles.

Method. The paper main aim is analysis of current problems in line management and compare any approaches to management in monitored six Czech SMEs. The survey was conducted from March to April 2018, by questionnaire. The relevant data were obtained from 258 respondents. The data analysis was based on the calculation of relative frequencies and the evaluation of the dependence of responses on gender and age of respondents using contingency tables. The research question is: What are the opinions of employees of the surveyed companies on management and how do they differ according to the type of company?

Results. The results show that surveyed SMEs are able to effectively manage. Management practices in SMEs should be focused on management styles, employee evaluation and compensation to achieve expected organizational results through achieving desired employee results.

Conclusions. The paper summarizes the results of the authors' questionnaire survey on managing people in six Czech profit SMEs. The results are interesting for the research and managers of SMEs who are responsible for managing employees. The results open up new possibilities for further research in the field of management.
\end{abstract}

Limitations. The main limitation are results of only six SMEs and sample size.

Keywords. Czech Republic; management styles; people management; small and medium-sized enterprise

https://doi.org/10.5817/CZ.MUNI.P210-9488-2019-22 


\begin{abstract}
Abstrakt
Cíl. Malé a střední podniky (MSP) hrají důležitou roli v ekonomickém rozvoji a mnozí z nich považují vedení zaměstnanců za důležitý zdroj pro dosažení očekávaných cílů. Teorie vychází z charakteristiky různých stylů ř́zení.
\end{abstract}

Metody. Hlavním cílem práce je analyzovat aktuální př́stupy $k$ řizení zaměstnanců na liniové úrovni a porovnat některé př́stupy k ř́zení ve zkoumaných šesti českých MSP. Dotazníkový průzkum byl proveden od brezna do dubna 2018, údaje byly získány od 258 respondentů. Analýza dat vycházela z výpočtu relativnich frekvenci a hodnoceni závislosti odpovédí na pohlaví a věku respondentů, kontingenčni tabulky. Výzkumná otázka zní, Jaké jsou názory zaměstnanců zkoumaných firem na ř́zení a jak se odlišuji podle typu firmy?

Výsledky. Výsledky ukazuji, že zkoumané malé a střední podniky jsou schopny efektivně rídit. Manažerské postupy $v$ malých a středních podnicích by měly být zaměreny na styly ř́zení, hodnocení zaměstnanců a odměňování, aby se dosáhlo očekávaných výsledkủ organizace prostřednictvím dosažení požadovaných výsledků zaměstnanců.

Závěr. V př́spěvku jsou shrnuty výsledky dotazníkového šetřeni autorů o řizení lidi v šesti českých MSP. Výsledky jsou zajímavé pro výzkum a manažery malých a středních podnikü, kteři jsou odpovědní za řízeni zaměstnanců. Výsledky přinášeji nové možnosti dalšího výzkumu v oblasti rízení.

Limity. Hlavním omezením jsou výsledky pouze šesti malých a středních podniků a velikost výběrového souboru respondenti̊.

Klíčová slova. Česká republika; styly řízení; řízení lidí; malý a střední podnik

\title{
Úvod
}

Malé a střední podniky (MSP) hrají důležitou roli v ekonomickém rozvoji a mnohé z nich považují vedení zaměstnanců za důležitý zdroj pro dosažení očekávaných cílů. Hlavním cílem statě je analyzovat př́stupy $\mathrm{k}$ řízení zaměstnanců na liniové úrovni a porovnat některé př́stupy $\mathrm{k}$ řízení ve zkoumaných šesti českých MSP vyplývající z výsledků dotazníkového šetření autorů o některých aspektech řízení lidí v malých a středních podnicích $\mathrm{v}$ České republice.

Malé a střední podniky jsou důležitou součástí hospodářského rozvoje a významně přispívají $\mathrm{k}$ regionálnímu hospodářskému rozvoji vytvářením nových pracovních míst, poskytováním investičních příležitostí a vytvářením ekonomického kapitálu a potenciálu potřebného pro udržitelný hospodářský růst (Šafránková \& Šikýř, 2017). Lidský potenciál představuje schopnosti a motivy lidí k plnění dohodnuté práce, $\mathrm{k}$ dosažení požadovaných výsledků a k realizaci očekávaných cílů organizací a zároveň k rozvoji sebe sama (Vodák \& Kucharčíková, 2011). Prostřednictvím efektivního řízení a vedení je možné efektivně ovlivňovat dovednosti, motivaci a výkonnost lidí i výkonnost organizace.

Manažer nese odpovědnost za výsledky nejen své práce, ale i za výsledky svých podřízených (Armstrong, 2015; Koubek, 2015). Optimálním nasazením všech zdrojů 
dosáhnout nejlepších výsledků (Pilařová, 2016). Je odpovědný za své chyby i za chyby spolupracovníků. To vyžaduje škálu manažerských dovedností spolu se schopností kooperace s ostatními spolupracovníky a synchronizace práce podřízených. Úspěch závisí na schopnosti jednat s lidmi, předvídat, rozhodovat, komunikovat, důležitá je spolupráce a týmová práce. Zajistit rovnováhu cílů, které mají dosahovat maximálních zisků, ale zároveň se potýkají s požadavky podřizených na maximální mzdy, do konfliktu se dostávají ekonomické cíle s cíli ekologickými, požadavek na snížení nákladů jde často na úkor kvality výrobků. Být připraven rozhodovat $\mathrm{v}$ každých podmínkách, rozhodnutí mohou být více nebo méně riziková, míra nejistoty může být plánovaná a co nejvíce redukovaná, ale nikdy nelze vyloučit neočekávané problémy.

Cílem řízení diverzity je vytvořit podmínky v organizacích, které umožní všem lidem plně rozvinout svůj osobní potenciál bez ohledu na jejich individuální rozdíly (Kocianová, 2012). Uplatňování principů řízení diverzity, právě proto, že zvyšuje potenciál tvořivosti pracovních skupin a nalézá nová řešení širšího spektra názorů, názorů a myšlenek členů různých pracovních skupin (Kislingerova et al., 2008). Dobře řízené řízení diverzity může pozitivně ovlivnit výsledky jednotlivců, týmů a organizací. (Parker, Arrowsmith, \& Haar, 2017).

\section{Metoda}

Průzkum zaměřený na spokojenost zaměstnanců s vedením ve firmách s vazbou na problematiku diverzity managementu, byl realizován $\mathrm{v}$ březnu a $\mathrm{v}$ dubnu 2018 , údaje byly získány od 258 respondentů (100 respondentů vyplnilo pouze část dotazníku, nezpracováno) v šesti českých MSP. Podniky byly vybrány podle požadavků projektu na území hlavního města Prahy, z oslovených padesáti o šetření zaměřené na diverzity management souhlasilo 15 a následně bylo vybráno zkoumaných šest na základě diferenciace $\mathrm{v}$ počtu zaměstnanců a činnosti. V projektu bylo schváleno podrobné zkoumání šesti MSP.

Dotazník byl vytvořen autory na základě vlastních předcházejících dotazníků a zkušeností s výzkumy v podnicích. Některé otázky byly vytvořeny podle Likertovy škály, některé byly otevřené, tak aby se zajistila nejlepší výpovědní schopnost v jednotlivých oblastech. Výzkumná otázka: Jaké jsou názory zaměstnanců zkoumaných firem na řízení a jak se odlišují podle typu firmy? Dotazník obsahoval 112 otázek s výběrem otázek týkajících se řízení, řízení výkonnosti a spokojenosti s benefity, možností vzdělávání zaměstnanců a řízení diverzity. Ze 112 otázek je 31 zaměřeno na řízení, další na problematiku personalistika a na diskriminaci.

Třídění bylo realizováno podle pohlaví, věku, národnosti, úrovně vzdělání, postavení v podniku. Sběr dat byl přes dotazník Survio.

Analýza dat vycházela z výpočtu relativních frekvencí a hodnocení závislosti odpovědí na identifikačních znacích respondentů, kontingenční tabulky.

Podniky byly různorodé a většinou se dotazníkového šetření zúčastnila většina zaměstnanců. Firma zaměřená na Účetnictví - 12 zaměstnanců, vyplnili všichni, tj. 5 \% celého výběrového souboru, Wellness - 61 respondentů (celkem 67 zaměstnanců), tj. $24 \%$ celého 
výběrového souboru, Vzdělávání - 52 respondentů (celkem 70), tj. $20 \%$ celého výběrového souboru, Personální agentura 1- 53 respondentů (celkem 456), tj. $20 \%$ celého výběrového souboru, Personální agentura 2 - 48 respondentů (celkem 250), tj. $19 \%$ celého výběrového souboru, Výroba potravin - 32 respondentů (celkem 75 ,), tj. 12 \% celého výběrového souboru.

V celém výběrovém souboru je 54 \% žen a $46 \%$ mužů, takže výsledky mohou být komparovány z hlediska diferenciace názorů podle pohlaví respondentů. Podle věku, je ve sledovaném výběrovém souboru zaměstnanců, rozdělení výběrového souboru následující: 37 \%, tj. 96 osob je mladších 25 let, 54 \%, tj. 138 osob je ve věku mezi 26 do 54 let a $9 \%$ pracovníků nad 55 let věku.

Z hlediska národností je 93 \% Čechů či Slováků a jen 7 \% př́slušníků jiné národnosti, $84 \%$ (216 osob) respondentů je na pozici řadového zaměstnance, $12 \%$ (30 osob) na pozici nižšího a středního managementu a $4 \%$ (12 osob) na pozici vrcholového managementu. U jednotlivých firem pracují respondenti většinou krátce do 1 roku, je to $70 \%$ respondentů, 1-4 roky $26 \%$ a nad 5 let $4 \%$. Změnu pozice u stejné společnosti v době trvání pracovního poměru uvádí $31 \%$ z nich, nespokojeny se změnou jsou $4 \%, 62 \%$ pozici neměnilo a $7 \%$ nemohlo změnit, a proto není spokojeno.

\section{Výsledky}

Základem efektivního řízení jsou vzájemné pracovní vztahy mezi nadřízeným a podřízenými, tzn. mezi vedoucím a výkonným pracovníkem a pak z hlediska spolupráce kvalita vztahů mezi jednotlivými pracovníky.

Ve sledovaných podnicích uvedla většina respondentů, že mají podporu při práci od nadřízených (tři čtvrtiny respondentů (72\%), 19 \% jen částečnou a $9 \%$ uvedlo, že ne). Vztahy na pracovišti hodnotí většina respondentů jako většinou přátelské (85\%). S kolegy se stýká mimo pracovní dobu $28 \%$ dotázaných, ostatní málo nebo vůbec. Ve stresu v práci se cítí jen celkem $13 \%$ dotázaných.

Více jak polovina respondentů uvedla, že je řízena spíše participativně s důrazem na samostatnost práce (účetnictví, wellness, vzdělávání, částečně personální agentury). Direktivní řízení převažuje ve výrobě potravin, částečně personální agentury. Styly řízení odpovídají většinou typu pracovního místa.

Spory v práci jako výjimečné uvádí většina respondentů (63\%), občasné jsou podle jedné pětiny, tj. $22 \%$ dotázaných a jen $15 \%$ se se spory v práci setkává častěji. Krizové situace v práci řešilo $42 \%$ dotázaných, $58 \%$ uvedlo, že ještě ne. Skoro polovina respondentů (47\%) ale uvedla, že v práci řeší drobné konflikty. Řešení konfliktní situace bylo pro $10 \%$ dotázaných nesmírně obtížné, pro 25 \% spíše obtížné a pro ostatní spíše jednoduché a psychicky nenáročné. $\mathrm{S}$ výsledkem bylo $60 \%$ dotazovaných spokojeno. Více jak polovině respondentů pomohl vedoucí (55\%). Dvě třetiny (67\%) respondentů se domnívají, že firmě záleží na předcházení konfliktům.

Se systémem hodnocení vedoucím je spokojena polovina respondentů, tj. $49 \%$, průměrnou spokojenost uvádí $22 \%$, tj. více než jedna pětina a určitou nespokojenost $29 \%$, tj. 
skoro jedna třetina dotázaných. Více jak polovina respondentů uvádí, že s nimi nadřízení vedou hodnotící pohovory. Dvě třetiny respondentů (62\%) uvádí, že jsou nadřízeným motivováni, vice jak jedna čtvrtina je motivována částečně $(25 \%)$, pouze $14 \%$ respondentů uvedlo, že se necítí být motivováno.

S hodnocením souvisí spokojenost s platem, resp. mzdou, které jsou ale důvěrnou informací, takže lze konstatovat jen pocit a domněnky respondentů. Diskriminováno u výše platu/mzdy z hlediska věku se cítí pouze 6 respondentů, což jsou $2 \%$ a kvůli jiné národnosti než české nebo slovenské (1 respondent). U výše mzdy tedy respondent uvádějí svůj pocit diskriminace jen jednotlivě, není to problém ani u jedné ze zkoumaných firem.

Vedoucí pracovník odpovídá také za další vzdělávání svých podřízených. Ve zkoumaných podnicích více jak polovina respondentů nebyla $\mathrm{v}$ posledním roce na žádném školení, což je velkým problémem, nebot' je povinností podniku zajistit průběžné další vzdělávání zaměstnanců. $26 \%$ respondentů absolvovalo v minulém roce jeden až maximálně deset dní profesních školení. Jedna třetina respondentů absolvovala školení ze zákona a jedna pětina odborná pro výkon povolání. Školení měkkých dovedností a cizích jazyků se zúčastnili jen jednotlivci. Dotázaní by se rádi vzdělávali v oblasti měkkých dovedností a v cizích jazycích. Většina dotázaných se vzděláním není spokojena (70 \%) a polovina by uvítala větší nabídku vzdělávání ze strany zaměstnavatele. S výsledky školení se systematicky pracuje jen ve 30 \%.

Jednou z důležitých oblastí podpory spokojenosti zaměstnanců jsou benefity. Ty nesouvisí př́imo s vedením, ale významně podporují stimulaci k pracovnímu výkonu. $16 \%$ respondentů uvedlo, že společnost dává benefity, jiní respondenti nevěděli. Spokojenost $\mathrm{s}$ benefity ale uvedlo $31 \%$ respondentů, částečně spokojených s $30 \%$ a částečně spokojených s $33 \%, 6 \%$ se k nim nevyjádřilo. Respondenti často nevědí, že jsou možnosti flexibilní pracovní doby součástí benefitů. Většina zkoumaných společností využivá flexibilní pracovní dobu, práci z domova a príspěvek na dopravu, stravenky. Současně stravenky byly nejvíce uvedeny jako požadavek u firem, které je neposkytují. Pružnou pracovní dobu využívá 37 \% a 14\% respondent by mělo zájem ji využívat, ale jejich firmy ji nenabízí. Zkrácený pracovní úvazek využívá $16 \%$ dotázaných, 13 \% by mělo o zkrácený pracovní úvazek zájem, ale jejich firma je neposkytuje.

Ve zkoumaných podnicích, vzhledem k tomu, že se jedná o MSP, jsou malé možnosti postupu, tzn. změny pozice a současně omezené možnosti zvyšování kvalifikace. Zájem respondentů o postup odpovídá možnostem podniku, tzn., že 70 \% o zvyšování kvalifikace nemá zájem, $20 \%$ uvádí, že zájem mělo a vedení je podpořilo a pouze 8 \% (19 respondentů) uvedlo, že zájem měli, ale nesetkali se s podporou vedení.

Změnu pozice pro stejnou společnost $\mathrm{v}$ době zaměstnávání uvádí $31 \% \mathrm{z}$ nich, nespokojeni se změnou $4 \%, 62 \%$ se nezměnilo a $7 \%$ se nemohlo změnit, a tudíž nespokojeno. Negativní názory se objevily pouze u 4 respondentů, kteří změnu pozice vnímali jako částečně diskriminační z hlediska pohlaví.

V celém šetření se neprokázaly statisticky významné rozdíly podle pohlaví a věku v oblasti otázek zaměřených na problematiku řídících činností. 


\section{Diskuse}

Jak doporučuje současná odborná literatura (srov. Armstrong \& Taylor, 2015; Pauknerová, 2012; Pilařová, 2016,) tak liniový manažer by měl řídit především situačním řizením, tzn. podle schopností pracovníka a konkrétního úkolu. I v tomto rozsahem malém šetření se prokázalo, že většina zaměstnanců je řízena participativně, pouze tam, kde je to vhodné, tzn. ve výrobě direktivně. Odpovídá tomu typ práce a vzdělání a kvalifikace pracovníků. Ti zaměstnanci, kteří mají střední a vysokoškolské vzdělání a vykonávají pozice $\mathrm{s}$ vyšší mírou zodpovědnosti jsou řízeni participativně, ti, kteří vzdělání střední odborné bez maturity a vykonávají práce manuální, převažuje řízení direktivní. Dále uvádí, že liniový manažer nese odpovědnost za výsledky svých podřízených, s tímto souhlasí skoro všichni $\mathrm{z}$ respondentů. Vedení vyžaduje schopnosti jednat s lidmi, předvídat, rozhodovat, komunikovat, důležitá je spolupráce a týmová práce. Zkoumaní pracovníci se přiklánějí k tomu, že jejich vedoucí s nimi řeší konfliktní situace. Relativně rozsáhlá oblast odpovědnosti liniových manažerů je za personální činnosti. Respondenti se shodují, že jsou celkem spokojeni se způsobem hodnocení, mzdou a motivací. Jedna třetina je spokojena se stimulací formou benefitů, které většina ze zkoumaných firem neposkytuje. Ve většině zkoumaných firem je možnost pružné pracovní doby a práce z domova, která vyhovuje většině dotázaných. Problémy se prokázaly v oblasti vzdělávání, kdy respondenti v posledním roce neabsolvovali žádné odborné školení. Současně se prokazuje malá možnost postupu, omezená především plochou strukturou řízení v malých a středních firmách. Zjištěné výsledky odpovídají situaci v malých a středních podnicích publikovaných v odborných článcích (srov. Barbuto \& Gottfredson, 2016; Madera, 2018; Ruchkina, Melnichuk, Frumina \& Mentel, 2017).

\section{Závěr}

Pro liniový management z výsledků šetření lze obecně doporučit sledování komunikace, vztahů s podřízenými, které ovlivňují spokojenost zaměstnanců a pak s tím související kvalitu a produktivitu práce.

Vztahy s manažery a pracovními vztahy většina respondentů hodnotí jako přátelské. S kolegy je $\mathrm{v}$ dobrých vztazích i mimo pracoviště jedna třetina respondentů. Dvě třetiny respondentů se domnívají, že organizace je odhodlána předcházet konfliktům. Jedna třetina respondentů ví, že v organizaci existují postupy řešení konfliktů. Pouze jedna desetina respondentů pocituje stres $\mathrm{v}$ práci. Hodnotící pohovory neprobíhají ve všech zkoumaných organizacích. Průběžná motivace pracovníků probíhá.

Výsledky ukazují situaci v analyzovaných šesti malých a středních podnicích $\mathrm{v}$ př́istupu $\mathrm{k}$ řízení a k řízení diverzity. Některé rozdíly jsou v názorech a vnímání diskriminace $\mathrm{z}$ hlediska věku a pohlaví, více z těchto problémů se projevují u mladých lidí do 30 let.

Ve zkoumaných organizacích se z hlediska managementu lidí oblasti pro zlepšení projevují především ve vzdělávacích a evaluačních procesech. Všech šest firem nemá program pro zaměstnance $50+$. Benefity nejsou prripraveny pro zaměstnance, jsou zejména pro management. Ženy se nepovažují za diskriminované.

Z výsledků byly vytvořeny a předány vedení zkoumaných firem návrhy na revizi 213 
mzdového systému, systému benefitů, systému vzdělávání, zavedení více principů týmové práce a systematického řízení konfliktů. Hlavním omezením výsledků je realita, že výsledky se týkaly podrobné analýzy pouze šesti malých a středních podniků a nelze je zobecňovat.

\section{Literatura}

Armstrong, M., \& Taylor, S. (2015). Řizení lidských zdrojů. Moderní pojetí a postupy. Praha: Grada Publishing.

Barbuto, J. E., \& Gottfredson, R. K. (2016). Human capital, the millennial's reign, and the need for servant leadership. Journal of Leadership Studies, 10(2), 59-63. http://doi.org/10.1002/jls.21474

Collins, J., \& Porras, J. I. (2016). Jak vybudovat trvale úspěšnou firmu. Úspěšné návyky vizionářských společností. Praha: Grada Publishing.

Kislingerová, E. et al. (2008). Inovace nástrojů ekonomiky a managementu organizací. Praha: C. H. Beck.

Kocianová, R. (2012). Personální rízení. Východiska a vývoj. Praha: Grada Publishing.

Koubek, J. (2015). Řizení lidských zdrojů. Základy moderní personalistiky. Praha: Management Press.

Madera, J. M. (2018). Situational perspective taking as an intervention for improving attitudes toward organizations that invest in diversity management programs. Journal of Business and Psychology, 33(3), 423-442. http://doi.org/10.1007/s10869-017-9502-0

Parker, J., Arrowsmith, J., \& Haar, J. (2017). Diversity management in New Zealand: towards an empirically-based model of employer propensity to manage diversity. Labour \& Industry - A Journal of the Social and Economic Relations of Work, 27(1), 34-55. http://doi.org/10.1080/10301763.2017.1310433

Pauknerová, D. a kol. (2012). Psychologie pro ekonomy a manažery. Praha: Grada Publishing.

Pilařová, I. (2016). Leadership \& management development. Role, úlohy a kompetence managerů a lídrů. Praha: Grada Publishing.

Ruchkina, G., Melnichuk, M., Frumina, S., \& Mentel, G. (2017). Small and medium enterprises in regional development and innovations. Journal of International Studies, 10(4), 259-271. http://doi.org/10.14254/2071-8330.2017/10-4/20

Šafránková, J. M., \& Šikýř, M. (2017). Perspektivy rozvoje lidského potenciálu: Výzvy současné praxe ř́zení lidských zdrojů. Ostrava: KEY Publishing s.r.o.

Vodák, J., \& Kucharčíková, A. (2011). Efektivní vzdělávání zaměstnanců. Praha: Grada Publishing. 


\section{Korespondující autor}

doc. PhDr. Jana Marie Šafránková, CSc.

Vysoká škola regionálního rozvoje a Bankovní institut, Ambis, a.s.

Lindnerova 575/1, 18000 Praha 8, Česká republika

jana.safrankova@ambis.cz

Grantová podpora: Př́íspěvek byl podpořen $\mathrm{z}$ Projektu No:

CZ.03.1.51/0.0/0.0/16_051/0006318, „Realizace gender auditů dynamicky se rozvíjejících firem na území hl. m. Prahy“ 


\title{
Effect of entrepreneurial education on development of entrepreneurial competencies
}

\section{Efekt podnikatel'ského vzdelávania na rozvoj podnikatel'ských kompetencií}

Andrea Zelienková ${ }^{1}$, Zuzana Kožárová ${ }^{2}$

${ }^{1}$ Institute of Experimental Psychology, Slovak Academy of Science

${ }^{2}$ Centre of Social and Psychological Sciences

\begin{abstract}
Objectives. The purpose of this paper was to explore the impact of entrepreneurial education on entrepreneurial competence development, specifically knowledge, abilities and attitudes of university students. Entrepreneurial education was conducted at two universities.

Method. A quasi-experimental study was conducted on 12 university students with no entrepreneurial experience. We undertaken semi-structured interviews with participants after completing training programme to explore in depth changes in entrepreneurial competencies.

Results. Content analysis of semi-structured interviews showed significant change in entrepreneurial competencies. The most frequent changes were showed in category of knowledge for both universities.

Conclusion. Results of content analysis support conclusion, that our entrepreneurial education was effective for development of entrepreneurial competencies, foremost development of entrepreneurial knowledge.
\end{abstract}

Limitation. Limits of study stems from social desirability bias of respondent's answers and missing triangulation of methods.

Keywords. entrepreneurship education; knowledge; abilities; attitudes

https://doi.org/10.5817/CZ.MUNI.P210-9488-2019-23 


\begin{abstract}
Abstrakt
Ciel'. Ciel'om tohto výskumu bolo preskúmat' vplyv podnikatel'ského vzdelávania na rozvoj podnikatel'ských kompetencií, konkrétne vedomostí, schopnosti a postojov univerzitných študentov. Podnikatel’ské vzdelávanie sa uskutočnilo na dvoch univerzitách.
\end{abstract}

Metóda. Výskum mal charakter kvázi experimentu realizovaného na vzorke 12 študentov bez podnikatel'skej skúsenosti. Po ukončeni programu sme so študentmi realizovali semištruktúrované rozhovory na zistenie híbkových zmien v podnikatel'ských kompetenciách.

Výsledky. Obsahová analýza semi-štruktúrovaných rozhovorov poukázala na signifikantné zmeny v kompetenciách. Najviac frekventované zmeny sa ukázali v kategórii vedomostí na oboch univerzitách.

Závery. Na základe výsledkov obsahovej analýzy sa javí, že účastníci považovali náš podnikatel'ský program za rozvijajúci podnikatel'ské kompetencie, predovšetkým podnikatel'ské vedomosti.

Limity. Limity štúdie vyplývajú zo sociálnej žiadúcnosti odpovedí respondentov a chýbajúcej triangulácie metód.

Kl’účové slová. podnikatel'ské vzdelávanie; vedomosti; schopnosti; postoje

\title{
Úvod
}

Globálny monitor podnikania (2017) v medzinárodnom porovnaní poukázal na vel’mi nízku atraktivitu podnikania ako kariérovej vol’by na Slovensku. Uvažovanie o podnikaní ako potenciálnej kariére posilňuje podnikatel'ské vzdelávanie, avšak Slovak Business Agency poukazuje na nedostatočnú realizáciu podnikatel'ských programov, absenciu kompetenčného zarámcovania a vel'kú zameranost' na formálne vzdelávanie (Slovak business agency, 2019). Caird (1990) delí podnikatel'ské vzdelávanie na vzdelávanie o podnikaní (education about entrepreneurship), vzdelávanie pre podnikanie (education for entrepreneurship) a výchovu podnikavého jedinca (education for enterprising person). Ciel’om vzdelávania pre podnikanie je podpora podnikatel'skej aktivity, ciel'om vzdelávania vodnikaní je nadobúdanie kompetencií typických pre podnikavého jedinca a napokon, rozvoj povedomia o podnikaní je zámerom vzdelávania o podnikaní. Vychádzajúc z delenia Caird (1990) je podnikatel'ské vzdelávanie možné definovat' ako rozvoj podnikatel'ských kompetencií a zvyšovanie povedomia o podnikatel'skej kariére. Morris, Webb, Fu a Singhal (2013) kritizujú slabé zameranie na špecifické podnikatel'ské kompetencie, akými je napríklad rozpoznávanie príležitostí a hodnotenie podnikatel'ských príležitostí v rámci podnikatel'ských programov. Ciel’om nášho podnikatel'ského programu bolo reagovat' na kritiku Morrisa a kolektívu (2013) a viac klást' dôraz na rozvoj všeobecných podnikatel'ských kompetencií (vedomosti, schopnosti, postoje), ako aj špecifických podnikatel'ských kompetencií. 


\section{Výskumný ciel'}

Ciel'om nášho výskumu bolo skúmat' vplyv podnikatel'ského vzdelávania na rozvoj podnikatel'ských kompetencií - vedomostí, schopností a postojov. Okrem kvalitatívnej analýzy rozhovorov plánujeme zist'ovat' aj frekvenciu zastúpenia konkrétnych podnikatel'ských kompetencií.

VO: Aké podnikatel'ské kompetencie nadobudli účastnici programu?

VO1: Aké podnikatel'ské vedomosti nadobudli účastníci programu?

VO2: Aké podnikatel'ské schopnosti nadobudli účastníci programu?

VO3: Aké podnikatel'ské postoje nadobudli účastníci programu?

\section{Popis podnikatel'ského programu}

Kl'účová línia vzdelávania bola zostavená v súlade s procesom prípravy podnikatel'skej činnosti s počiatočným zhodnotením vlastného potenciálu, pokračujúc rozvojom vlastného podnikatel'ského nápadu až po vytvorenie podnikatel'ského plánu a jeho prezentáciu. Podnikatel'ské vzdelávanie bolo rozdelené do siedmich tematicky zameraných modulov pozostávajúcich z hlavných prezentácií rozvíjajúcich kompetencie (ako napríklad ekonomické a právne aspekty podnikania), prezentácií vzorov - úspešných podnikatel'ov a rôznych aktivizačných metód (diskusia s podnikatel'mi, tímová práca, prezentácia nápadu...) (Malach, 2008). V tréningovom programe sme využívali kombináciu tradičného prístupu k vzdelávaniu - výklad (modul 5 a 6), avšak dominovali aktivizujúce metódy, ktoré sa odporúčajú pre rozvoj podnikatel'skej kompetencie (Malach, Durda, 2007). Išlo napr. o brainstorming, tímovú prácu, hry, a iné (modul 1,2,3,4,7). Súčast'ou jednotlivých modulov boli prizvaní externí lektori (napr. expert na financie, či právo $\mathrm{v}$ oblasti podnikania) a hostia - podnikatelia, ktorí pôsobia $\mathrm{v}$ lokálnom prostredí. Účastníci tak dostali najrelevantnejšie informácie z biznis prostredia, efektívne sa prepájala akademická pôda s podnikatel'mi a zároveň sa vytvorila príležitost' na networking. Participácia v programe plnila i motivačnú funkciu programu, ked’že účastníci programu mali možnost' vypočut' si inšpiratívny príbeh podnikatel'ov a diskutovat's nimi na rôzne témy (bližšie o podnikatel'skom programe autorky Zuzany Kožárovej v publikácii Kariérové poradenstvo v teórii a praxi, 2018).

Obsah modulov podnikatel'ského programu bol nasledovný:

1. modul $=$ sebapoznanie, zamestnanec vs. podnikatel'

2. modul $=$ osobnost' podnikatel'a, hodnotenie podnikatel'ského potenciálu

3. modul $=$ vnímanie, identifikovanie a hodnotenie podnikatel'ských príležitostí

4. modul $=$ podnikatel'ský plán

5. modul $=$ ekonomické aspekty podnikania

6. modul $=$ právne aspekty podnikania

7. modul $=$ finálna individuálna prezentácia vlastných podnikatel'ských plánov

\section{Výskumná vzorka}


Výskumnú vzorku tvorilo 12 študentov (7 - TP UPJŠ v Košiciach, 5 - TP UK v Bratislave). Výber účastníkov bol príležitostný, participanti sa prihlásili do programu dobrovol'ne.

Tabul'ka 1. Charakteristika výskumnej vzorky

N $\quad$ Muž Žena $\quad$ M (Vek) $\quad$ Stupeň štúdia $\quad$ Odbory

$(1,2,3)$

\begin{tabular}{|c|c|c|c|c|c|c|c|c|c|}
\hline$\overline{\text { UPJŠ }}$ & $\begin{array}{l}\text { Experimentálna } \\
\text { skupina }\end{array}$ & 7 & 4 & 3 & 22,29 & 4 & 1 & 2 & $\begin{array}{c}\text { Psychológia } \\
\text { Fyzika } \\
\text { Verejná } \\
\text { správa }\end{array}$ \\
\hline UK & $\begin{array}{l}\text { Experimentálna } \\
\text { Skupina }\end{array}$ & 5 & 0 & 5 & 21,4 & 3 & 2 & 0 & $\begin{array}{l}\text { Aplikovaná } \\
\text { psychológia }\end{array}$ \\
\hline
\end{tabular}

\section{Zber dát}

Rozvoj podnikatel'ských kompetencií vplyvom podnikatel'ského programu sme skúmali prostredníctvom polo-štruktúrovaných rozhovorov. Jedným z možných hodnotiacich rámcov podnikatel'ských vzdelávaní je Kirkpatrickova hodnotiaca schéma, ktorí patrí medzi najakceptovanejšie a najvplyvnejšie rámce. Jedným $\mathrm{z}$ hodnotených aspektov je učenie $\mathrm{v}$ zložkách vedomostí, schopností a postojov. Nadobudnuté podnikatel'ské kompetencie je možné skúmat' prostredníctvom diskusie o výstupoch programu alebo nepriamymi metódami, akými sú hodnotiace škály alebo dotazníky (Gedeon, 2017). Ked’že kvantitatívne skúmanie rozvoja kompetencií na malej vzorke má svoje obmedzenia z hl'adiska významnosti, rozhodli sme sa rozvoj podnikatel'ských kompetencií do väčšej híbky preskúmat' prostredníctvom rozhovorov.

Realizácia rozhovorov prebiehala po súhlase respondentov o vytvorení audio nahrávok, ktoré boli následne prepísané alebo boli odpovede respondentov písomne zaznamenávané. Rozhovory realizovali lektorky programu. $\mathrm{Na}$ základe relevantnej literatúry o rozvoji podnikatel'ských kompetencií (napríklad Lackéus, 2013; Lackéus, 2015) sme určili tri otázky na zist'ovanie rozvoja podnikatel'ských kompetencií (Vedomosti - „, Čo si sa naučil/a na tréningovom programe?", Schopnosti - „Aké schopnosti si získal/a na tréningovom programe? “, Postoje - „Zmenil sa tvoj pohl'ad na podnikanie? “, „Ako? “). V prípade uvádzania menej špecifických odpovedí respondentov sa lektorky programu situačne doplňujúcimi otázkami pýtali na rozvoj konkrétnych kompetencií. Prvý program sa realizoval v akademickom roku 2017/2018, v ktorom boli otázky v rozhovoroch pilotne overené. Podnikatel'ský program, ktorého efektivitu v oblasti rozvoja kompetencií sme skúmali, sa realizoval v akademickom roku 2018/2019.

\section{Metóda analýzy dát}

Dáta boli analyzované prostredníctvom kvalitatívnej obsahovej analýzy doplnenej o analýzu frekvencie kódov v rozhovoroch s ciel’om detailne preskúmat' vzdelávaním 
nadobudnuté podnikatel'ské kompetencie. Obe výskumníčky kódovali dáta z jednotlivých programov samostatne. Z textu boli vyvodené kódy a ku kódom boli priradené početnosti. Následne boli dáta spoločne zaradené do prislúchajúcich kategórií podnikatel'ských kompetencií. V prípade nezrovnalostí kategorizácie kódov sme vychádzali z publikácie Lackéus $(2015,2013)$. Dôveryhodnost' analýzy bola zabezpečená opakovaným kontrolovaním súladu medzi identifikovanými znakmi a rozhovormi s účastníkmi programu. Pre dosiahnutie spol'ahlivosti analýzy sme si s druhou výskumníčkou vymenili prepisy rozhovorov. Ked’že bol predmetom analýzy manifestný obsah textu a vychádzali sme z rovnakého teoretického rámca, po prečítaní textov druhej autorky sa spoločná diskusia týkala najmä zjednotenia názvu niektorých kódov (napr. zreálnenie podnikania). Výsledky obsahovej analýzy podporujeme slovnými vyjadreniami respondentov a významnost' témy $\mathrm{z}$ hl'adiska frekvencie sme sa rozhodli spracovat' $\mathrm{v}$ numerickej podobe absolútneho počtu tvrdení respondentov ( $\mathrm{v}$ zátvorkách) (Gavora, 2015).

Tabul'ka 2. Obsahová analýza zmien v postojoch, schopnostiach a vedomostiach

\begin{tabular}{|c|c|c|c|c|c|c|}
\hline & Postoje & $\mathbf{N}$ & Schopnosti & $\mathbf{N}$ & Vedomosti & $\mathbf{N}$ \\
\hline Bratislava & $\begin{array}{l}\text { Odvaha a kreativita } \\
\text { (1) } \\
\text { Zreálnenie } \\
\text { podnikania (4) } \\
\text { Väčšia } \\
\text { zodpovednost' (1) }\end{array}$ & 6 & $\begin{array}{l}\text { Vypracovanie podnika- } \\
\text { tel'ského plánu (3) } \\
\text { Metódy hodnotenia } \\
\text { nápadu (3) } \\
\text { Zameranie na nápad (1) } \\
\text { Strategické myslenie (1) } \\
\text { Vyhl'adávanie informácií } \\
\text { (1) }\end{array}$ & 9 & $\begin{array}{l}\text { Financie (2) } \\
\text { Získanie kapitálu (3) } \\
\text { Poznatky o podnikatel'- } \\
\text { ských centrách (1) } \\
\text { Plánovanie (1) } \\
\text { Rozdiel zamestnanec vs. } \\
\text { podnikatel' (1) } \\
\text { Prehl'ad v podnikaní (1) }\end{array}$ & 9 \\
\hline Košice & $\begin{array}{l}\text { Zreálnenie } \\
\text { podnikania (4) }\end{array}$ & 4 & $\begin{array}{l}\text { Vypracovanie podnika- } \\
\text { tel'ského plánu (3) } \\
\text { Prezentácia nápadu (5) } \\
\text { Rozpoznávanie } \\
\text { podnikatel'ských } \\
\text { príležitostí (2) }\end{array}$ & 10 & $\begin{array}{l}\text { Plánovanie (1) } \\
\text { Financie (3) } \\
\text { Získanie kapitálu (6) } \\
\text { Podnikatel'ský potenciál } \\
\text { (1) } \\
\text { Rozdiely zamestnanec vs } \\
\text { podnikatel' (1) } \\
\text { Podnikanie ako manaž- } \\
\text { ment l'udí (2) } \\
\text { Právne aspekty (6) } \\
\text { „Čo neviem“ (6) } \\
\text { Štruktúra podnikatel'ského } \\
\text { plánu (5) }\end{array}$ & 31 \\
\hline
\end{tabular}

\section{Výsledky}

Vo výsledkoch podporujeme slovnými tvrdeniami respondentov najviac relevantné kódy z hl'adiska obsahu a ciel'a programu. Na základe frekvencie tvrdení respondentov nastal najviac výrazný rozvoj vo vedomostiach a poznatkoch o právnych a finančných aspektoch 
podnikania. $\mathrm{V}$ oboch programoch sa $\mathrm{v}$ kategórií vedomostí frekventovane vyskytovali zdroje vedúce $\mathrm{k}$ získaniu kapitálu a právne aspekty podnikania. $\mathrm{Na}$ otázku čo sa na tréningovom programe naučili odpovedali napr.: ,, Určite hlavne financie - zdroje, odkial' by som mala mat' financie... " (Participant 1). - Napriklad tie právne aspekty. To som fakt nevedela. Nemala som o tom ani predstavu. To, že rodičia mali s.r.o. a najprv živnost'. Mamka sa snažila mi to vysvetlit', lebo som sa o to zaujímala, aký je medzi tým rozdiel. Ona sama sa však do toho nevyznala. Takisto kapitál, na čo všetko sa treba pozerat', čo všetko treba riešit' a tak. Takže hlavne takéto veci. Človek sa to nikde nenaučí, lebo v škole nás to neučia. Vškole t'a nepripravia na praktický život, už len stredná alebo základná škola. Nikde t’a nenaučia také tie praktické veci. "(Participant 2).

V schopnostiach nastal najviac výrazný rozvoj vo vypracovaní podnikatel'ského plánu - „Ako schopnost’ by som počítala to, že som teraz ako-tak schopná vypracovat'si podnikatel'ský zámer.“ (Participant 3), poznaní metód hodnotenia nápadu - „...vypracovanie SWOT analýzy... “(Participant 4) a prezentácii nápadu - „, No to prezentovanie. Síce to bol šok, že som dokázala prezentovat' pred l'ud'mi, ktorých nepoznám...Bola som na seba hrdá. “(Participant 5).

V rámci postojov si respondenti uvedomili, čo všetko kariéra podnikatel'a obsahuje a frekventovane uvádzali tvrdenia o tom, že podnikanie vnímajú viac reálne: „Beriem to vážnejšie. V podstate už to neberiem len tak, že ked' niekto podniká tak podniká, že to má viac prínosov ako t’ažkostí. Ale beriem to tak serióznejšie, že to nie je l'ahká práca. Myslím, že viac do toho vidím, než som videla predtým, aj ked' iba o trošičku a myslím, že som viac podnikavá. A som viac rozhodnutá ist' do toho podnikania. Predtým to bola taká myšlienka, že by som mohla a teraz už je to rozhodnutie, že chcem. " (Participant 2). Okrem zreálnenia podnikania majú niektorí účastníci väčšiu odvahu a podl'a tvrdení disponujú aj väčšou kreativitou: „,...možno byt' odvážnejšia a kreatívnejšia... “ (Participant 6).

\section{Frekvencia kódov v rozhovoroch}

Najviac zastúpená bola kategória vedomostí vychádzajúc $\mathrm{z}$ absolútneho počtu kódov $\mathrm{v}$ obidvoch programoch. Za vedomost'ami nasledovali schopnosti a postoje. V niektorých prípadoch respondenti uvádzali tvrdenia, ktoré neniesli konkrétnu informáciu o rozvoji kompetencií. V kategórií postojov respondenti uvádzali, že sa ich postoj nezmenil (1), nemali utvorený názor (1) alebo len uviedli, že sa ich postoj zmenil pozitívne (6). V rámci schopností nenastala žiadna zmena u dvoch respondentov (2).

Bližšie uvádzame kódy, ktoré sa v rozhovoroch respondentov vyskytovali aspoň tri krát. $\mathrm{Na}$ tréningovom programe UK bolo $\mathrm{v}$ rámci vedomostí najviac zastúpené poznanie zdrojov vedúcich k získaniu kapitálu (3). V kategórií schopností bolo najviac zastúpené poznanie metód hodnotenia nápadu (3) a vypracovanie podnikatel'ského plánu (3). V kategórii postojov boli najviac početné kódy týkajúce sa zreálnenia podnikania (4). Na tréningovom programe UPJŠ bolo v kategórií postojov z konkrétnych kódov zastúpené len zreálnenie podnikania (4). V kategórií schopností bola frekventovane uvádzaná schopnost' prezentácie nápadu (5) a druhé najviac frekventované schopnosti predstavovali vypracovanie podnikatel'ského plánu (3). V zložke vedomostí bol frekventovane zastúpený kód týkajúci sa zistenia respondentov o tom, 
kol'ko aspektov podnikania im nie je známych, alebo čo všetko nevedia (6). Rozvoj vedomostí nastal v poznaní zdrojov vedúcich $\mathrm{k}$ získaniu kapitálu (6), v oblasti právnych aspektov podnikania (6), poznaní štruktúry podnikatel'ského plánu (5) a finančných aspektoch podnikania (3).

\section{Diskusia}

Ciel’om nášho výskumu bolo preskúmanie vplyvu podnikatel'ského vzdelávania zameraného na rozvoj podnikatel’ských špecifických kompetencií. Zmeny v zložkách kompetencií - vedomostí, schopností a postojov sme zist'ovali prostredníctvom kvalitatívnych metód. V predošlých výskumoch sa ukázalo, že podnikatel'ské vzdelávanie rozvíja predovšetkým vedomosti (Matlay, 2008; Chen, Hsiao, Chang, Chou, Chen \& Shen, 2015). Účinnost' podnikatel'ských programov bola potvrdená $\mathrm{v}$ zmene úrovni vedomostí v rovnakých oblastiach, ako sa ukázalo aj v našom programe, teda v pochopení podnikania všeobecne, či poznaní zdrojov pre rozbehnutie podnikania (Európska komisia, 2012). Vychádzajúc z frekvencie kódov je možné naše vzdelávanie považovat' za najviac rozvíjajúce vedomosti, v súlade so zisteniami predošlých výskumov. Najviac výrazné zmeny nastali vo finančných, právnych aspektoch podnikania a poznaní štruktúry podnikatel’ského plánu. Dôvodom výraznej zmeny v zložke finančných a právnych aspektov podnikatel'ských vedomostí môže byt' aj skutočnost', že všetci respondenti študovali odbory mimo ekonomického a právneho zamerania.

Druhou zložkou kompetencií sú schopnosti. Rozvoj schopností v našom programe je v súlade so zmenami v schopnostiach predošlých výskumov, v ktorých sa potvrdila zmena v rozpoznávaní príležitostí (Karimi, Biemans, Lans, Chizari \& Mulder, 2014) a tiež schopnosti vytvorit' podnikatel'ský plán (Von Graevenitz, Harhoff \& Weber, 2010). Rozpoznávanie a hodnotenie príležitosti patria medzi kl'účové podnikatel'ské kompetencie, ktoré Morris a kolektív (2013) označili za nedostatočne rozvíjané v rámci podnikatel'ského vzdelávania. $\mathrm{Na}$ základe frekventovaných tvrdení o náraste schopností v tejto oblasti je náš program možné považovat' za rozvíjajúci špecifické podnikatel'ské kompetencie.

Tret'ou zložkou podnikatel'skej kompetencie sú postoje. Lackéus (2015) zaradil medzi postoje potrebné pre podnikanie kreativitu, proaktivitu a odhodlanie. Okrem viac reálneho náhl'adu na podnikanie boli v našej vzorke uvedené aj postoje väčšej odvahy podnikat'. Na základe tvrdení respondentov je možné usúdit', že podnikatel'ským vzdelávaním sa u niektorých respondentov rozvinuli vlastnosti podnikavého jedinca. Obsahovou analýzou sme dospeli k záveru, že podobný typ programu môže rozvíjat' podnikatel'ské vedomosti, schopnosti a postoje.

Jedným z možných limitov nášho výskumu je dostupný výber. K výsledkom s vyššou kredibilitou bolo možné dospiet' prostredníctvom náhodného výberu. Výber našej vzorky je však relevantný vzhl'adom k našim výskumným otázkam a ciel’om. Druhým limitom je analýza manifestného obsahu rozhovorov. K vyššej poznávacej hodnote bolo možné prostredníctvom latentného obsahu rozhovorov, avšak účel nášho výskumu naplnila analýza manifestného obsahu rozhovorov doplnená o frekvenciu výskytu kódov v rozhovoroch. Ďalším limitom je sociálna žiadúcnost' odpovedí respondentov a skreslenie vyplývajúce zo sebahodnotenia 
účastníkov programu. Výsledok analýzy manifestného obsahu rozhovorov sme netriangulovali použitím inej metódy. Za určitý typ triangulácie výsledkov a teda ukazovatel' istoty o správnosti záverov z kvalitatívneho výskumu (Bačová, 2003) je však možné považovat' skutočnost', že každý participant úspešne absolvoval záverečnú prezentáciu vytvorených podnikatel'ských plánov, ktorá vypovedá o mnohých aspektoch rozvoja podnikatel'ských vedomostí, schopností a postojov.

\section{Záver}

Prínos výskumu spočíva v hlbšom preskúmaní vplyvu podnikatel'ského vzdelávania na rozvoj podnikatel'ských kompetencií v porovnaní so štandardnými kvantitatívnymi metódami. Výsledky výskumu poskytujú účinnú spätnú väzbu pre efektivitu programu v oblasti rozvoja podnikatel'ských kompetencií. V budúcnosti je možné podnikatel'ské vzdelávanie aplikovat' aj na iných univerzitách, ktoré nedostatočne podporujú rozvoj podnikatel'ských kompetencií alebo sú v nízkej miere zamerané na rozvoj špecifických podnikatel'ských kompetencií.

\section{Literatúra}

Bačová, V. (2003). Ciele, kritériá a kvalita výskumu v psychológii. Československá psychologie, 47(3), 259-271.

Caird, S. (1990). What does it mean to be enterprising? British Journal of Management, 1(3), 137-145. http://doi.org/10.1111/j.1467-8551.1990.tb00002.x

Chen, S. C., Hsiao, H. C., Chang, J. C., Chou, C. M., Chen, C. P., \& Shen, C. H. (2015). Can the entrepreneurship course improve the entrepreneurial intentions of students? International Entrepreneurship and Management Journal, 11(3), 557-569. http://doi.org/10.1007/s11365-013-0293-0

European Commission (2012). Effects and impact of entrepreneurship programmes in higher education. Brussels: Entrepreneurship Unit, Directorate-General for Enterprise and Industry, European Commission B-1049.

Gedeon, S. A. (2017). Measuring student transformation in entrepreneurship education programs. Education Research International, 2017, ID 8475460. http://doi.org/10.1155/2017/8475460

Global Entrepreneurship Monitor (2018). Global report 2017/2018. Dostupné z: https://www.gemconsortium.org/report/50012

Gavora, P. (2015). Obsahová analýza v pedagogickom výskume: Pohl’ad na jej súčasné podoby. Pedagogická orientace, 25(3), 345-371. http://doi.org/10.5817/PedOr2015-3-345

Karimi, S., Biemans, H. J. A., Lans, T., Chizari, M. \& Mulder, M. (2014). Effects of Role Models and Gender on Students' Entrepreneurial Intentions, European Journal of Training and Development, 38(8), 1-15. http://doi.org/10.1108/EJTD-03-2013-0036

Kožárová, Z. (2018). PODNIKNI NIEČO! (Popis tréningového programu na rozvoj 
podnikavosti a kariérovej adaptability). Kariérové poradenstvo v teórii a praxi, 14, 43-49.

Lackéus, M. (2015). Entreprenuership in education. Dostupné z: https://www.oecd.org/cfe/leed/BGP Entrepreneurship-in-Education.pdf

Lackéus, M. 2013. Developing Entrepreneurial Competencies - An Action-Based Approach and Classification in Education. Licentiate Thesis, Chalmers University of Technology.

Malach, J., Durda, L. (2007). Didaktika podnikatelské výchovy. Ostrava: Pedagogická fakulta, Ostravská univerzita.

Malach, J. (2008). Výchova k podnikavosti a vysoké školy. Aula, 16(2).

Matlay, H. (2008). The impact of entrepreneurship education on entrepreneurial outcomes. Journal of small business and enterprise development, 15(2), 382-396. http://doi.org/10.1108/14626000810871745

Morris, M. H., Webb, J. W., Fu, J., \& Singhal, S. (2013). A competency-based perspective on entrepreneurship education: conceptual and empirical insights. Journal of Small Business Management, 51(3), 352-369. http://doi.org/10.1111/jsbm.12023

Slovak business agency (2019). Analýza podnikatel'ského vzdelávania. Dostupné z: http://www.sbagency.sk/sites/default/files/analyza_podnikatelskeho_vzdelavania.pdf.

von Graevenitz, G., Harhoff, D., Weber, R. (2010). The effects of entrepreneurship education. Journal of Economic Behavior \& Organization, 76(1), 90-112.

http://doi.org/10.1016/j.jebo.2010.02.015

\section{Corresponding author}

Andrea Zelienková

Ústav experimentálnej psychológie, SAV

Dúbravská cesta 5819/9, 84104 Karlova Ves

zelienkovandrea@gmail.com

Grantová podpora: Tento príspevok vznikol za podpory grantu Ministerstva školstva, vedy, výskumu a športu Slovenskej republiky VEGA č. 2/0118/17 s názvom: Posudzovanie rizika v rozhodovaní jednotlivcov o osobných a firemných/podnikatel'ských financiách a podnikatel'ských príležitostiach 


\title{
Leadership Competency Models within the Educational Setting
}

\section{Kompetenčné modely líderstva v edukačnom prostredí}

(prehl'adová štúdia)

Eva Sollárovál, Vladimír Poliach ${ }^{1}$, Lucia Pašková ${ }^{1}$, Zuzana Heinzovál, Beata ŽitniakováGurgová ${ }^{1}$

${ }^{1}$ Matej Bel University, Banská Bystrica, Slovakia

\begin{abstract}
Objectives. Standards and requirements on educational leader's competencies in the Slovak Republic do not fully use the potential of psychological know-how of leadership competency models. One of the aims of the APVV project no. 17-0557 ("Psychological approach to development, implementation and evaluation of the competence model of educational leaders' development") is to create a competency model for educational leaders that would be theoretically grounded and research-based. The paper presents the results of the introductory evaluation of specified international competency models for leaders in the educational setting.

Method. The method of the Frame Analysis by Ritchie \& Spencer (1994) using CAQDAS and multiple evaluations, was applied to selected U.S. educational leadership standards dated 2002 to 2017.

Results. The results show differences in metalanguage used and the structure of the models, as well as quite wide range of competencies included in the approaches to school and educational leadership standards/models.
\end{abstract}

Conclusions. The findings are discussed in the perspective of evaluating the conceptualization and development of educational leadership standards within the U.S. context.

Limitations. Narrowing the focus on the North American context as other studies (eg European) will follow.

Keywords. educational/teacher leadership standards; competency model; framework analysis

https://doi.org/10.5817/CZ.MUNI.P210-9488-2019-24 


\begin{abstract}
Abstrakt
Ciele. V podmienkach SR štandardy a požiadavky na kompetencie lídrov v edukačnom prostredí nevyuživajú dostatočne potenciál psychologického poznania v téme kompetenčných modelov líderstva. Jedným z ciel'ov projektu APVV-17-0557 "Psychologický pristup k tvorbe, implementácii a overovaniu kompetenčného modelu rozvoja lídrov v edukácii" je vytvorit" teoreticky ukotvenú a na výskumných zisteniach postavenú koncepciu kompetencií lídrov vedukačnom prostredí. Príspevok prezentuje výsledky úvodnej evaluácie vybraných zahraničných zdrojov v téme kompetencií/kompetenčných modelov lídrov v edukačnom prostredí.
\end{abstract}

Metóda. Na vybraných severoamerických zdrojoch z oblasti štandardov/modelov kompetencií školského a edukačného líderstva bola aplikovaná metóda Rámcovej analýzy (Ritchie \& Spencer) s využitím CAQDAS a zapojením viacerých hodnotitel’ov.

Výsledky. Výsledky poukazujú na pomerne vel'ké rozdiely v použitom metajazyku a štruktúre modelov, a na široký záber kompetencií v národných prístupoch koncipovania kompetenčných modelov školského a edukačného líderstva.

Závery. Zistenia sú diskutované vperspektíve zhodnotenia konceptualizácie a vývoja štandardov líderstva v edukačnom prostredí.

Limity. Zúženie záberu na severoamerický kontext, ked’že iným (napr. európskemu) sa budú venovat' d'alšie štúdie.

Kl'účové slová. štandardy edukačného/učitel'ského líderstva; kompetenčný model; rámcová analýza

\title{
Úvod
}

Hlavným ciel'om projektu APVV-17-0577 je vytvorit' taký kompetenčný model líderstva v edukácii (LvEd), ktorý využije potenciál súčasného psychologického poznania v tejto oblasti a bude použitel'ný ako báza pre systém rozvoja LvEd na Slovensku.

Kompetenčné modely sú vzt’ahové rámce, uvádzajúce kompetencie potrebné pre efektívny výkon špecifického povolania, skupiny povolaní, pracovných pozícií; pomáhajú ich pochopit' a aplikovat' (Marelli, 2005). Špecifikujú schopnosti, zručnosti, vedomosti, osobnostné črty etc. vhodné alebo nevyhnutné k pozícii, pre ktorú je model vytvorený (Smutný, Procházka \& Vaculík, 2014). Účelom ich aplikácie v edukačnom prostredí je jednak explicitné pomenovanie kompetencií, podporujúce efektívne vyučovanie a učenie sa študentov, ako aj umožnenie ich systematického rozvoja.

Východiskom ku tvorbe slovenského modelu kompetencií LvEd bola reflexia medzinárodného stavu problematiky. Začali sme exploráciou prístupov severoamerických edukačných asociácií, ktoré sú nielen celosvetovým iniciátorom výskumu v oblasti, ale aj dobrým príkladom variácií, vývoja a vplyvu na celoštátnu politiku vzdelávania.

Jednou z prvých organizácií, ktoré sa v USA a Kanade pričinili o vytvorenie štandardov pre líderstvo v školách je The National Policy Board for Educational Administration (NPBEA), 
zastrešujúce prácu dvoch nezávislých konzorcií. Ich modely štandardov líderských zručností z roku 2002 vymenúvajú parametre líderských zručností v školstve (ISLLC Standards, 2002 a ELCC Standards, 2002, obe neskôr aktualizované).

V roku 2008 skupina vzdelávatel'ov vytvorila Teacher Leadership Exploratory Consortium, kvôli aktualizácii výskumu vodcovských rol učitel’a. Výsledkom je publikácia Teacher Leader Model Standards (2010), deklarujúca účel štandardov - stimulovat' profesný dialóg o tom, čo tvorí poznatky, zručnosti a kompetencie, ktoré si potrebujú osvojit' učitelia vo vodcovských rolách. Ďalšia nezávislá iniciatíva učitel'ských asociácií The National Education Association (NEA), the National Board for Professional Teaching Standards, and the Center for Teaching Quality, spracovala modely Leadership Competencies Guide (LCG) a The Teacher Leadership Competencies (TLC) (2014/15).

Poznámka: Striedanie termínov „leadership“, „vodcovstvo“, „líderstvo“, „líderšip“ vyjadruje použitie anglosaských zdrojov, no i našu prekladatel'skú dilemu.

V prvotnej rýchlej analýze zdrojov sme sa zamerali hlavne na zodpovedanie nasledujúcich dvoch výskumných otázok:

VO1: Ako sú kompetenčné modely LvEd konceptualizované v U.S. kontexte?

VO2: Aké sú súvislosti a trendy vývoja kompetenčných modelov LvEd?

\section{Metódy}

\section{Dizajn štúdie}

Rýchla prehl'adová štúdia zdrojov prostredníctvom obsahovej analýzy a porovnania vybraných dokumentov bola súčast'ou konceptualizačnej etapy výskumu, s ciel'om vytvorit' východiskovú predstavu o konštrukcii kompetenčných modelov.

\section{Výskumná vzorka}

Pri výbere dokumentov sme kombinovali výsledky internetového prieskumu a štúdia literatúry (handbookov a encyklopédií). Na rozdiel od množstva publikovaných výskumných štúdií je publikovanie celonárodného edukačného štandardu v krajine vel’mi zriedkavým, až jedinečným, javom. Naša „výskumná vzorka“ sa preto rozsahom blíži populácii, hoci s ohl'adom na niekol'komesačné obdobie jej tvorby nie je možné tvrdit', že ide o cenzus. Tematickú saturáciu dokumentov však považujeme za vel'mi vysokú.

Pre analýzu bolo získaných 8 konkrétnych modelov štandardov LvEd (Tabul'ka 1). Zámerom bolo zachytit' reprezentatívne organizácie severoamerického kontextu, stojace za ich vytvorením a vplyvné vzhl'adom na záväznost' či ,,priestorový“ záber vytvorených štandardov. Zároveň sme usilovali o zachytenie rôznych koncepčných a vývinových trendov. Všetky použité štandardy boli publikované v rozpätí rokov 2002-2017. 
Tabul'ka 1. Výskumná vzorka modelov vybraných pre rámcovú analýzu $(n=8)$

\begin{tabular}{|c|c|c|c|}
\hline No & Názov a skratka & Vydávajúca platforma / teleso & Vydanie \\
\hline 1 & $\begin{array}{l}\text { The ISLLC } \\
\text { Standards }\end{array}$ & The Consortium of Chief State School officers (CCSSO) & $2002 / 11$ \\
\hline 2 & The ELCC Standards & $\begin{array}{l}\text { The Educational Leaderhip Consortium Council (member of } \\
\text { NPBEA) }\end{array}$ & 2002 \\
\hline 3 & $\begin{array}{l}\text { Teacher Leader } \\
\text { Standards }(T L M S)\end{array}$ & The Teacher Leadership Exploratory Consortium & 2010 \\
\hline 4 & $\begin{array}{l}\text { Standards Based } \\
\text { Leadership }(S B T L)\end{array}$ & $\begin{array}{l}\text { Tomal et. al, The Teacher Leader Core Competencies and } \\
\text { Strategies for Effective Leadership. }\end{array}$ & 2014 \\
\hline 5 & $\begin{array}{l}\text { Professional Standards for } \\
\text { Educational Leaders }(P S E L)\end{array}$ & $\begin{array}{l}\text { The National Policy Borad for Educational Administration } \\
\text { (NPBEA) }\end{array}$ & 2015 \\
\hline 6 & $\begin{array}{l}\text { Leadership } \\
\text { Guide (LCG) }\end{array}$ & $\begin{array}{l}\text { The Teacher Leadership Initiative as a result of cooperation } \\
\text { of the US bodies- the National Education Association (NEA), } \\
\text { the National Board for Professional Teaching Standards, and } \\
\text { the Center for Teaching Quality }\end{array}$ & $2014 / 15$ \\
\hline 7 & $\begin{array}{l}\text { The Teacher Leadership } \\
\text { Competencies }(T L C)\end{array}$ & $\begin{array}{l}\text { The Teacher Leadership Initiative as a result of cooperation } \\
\text { of the US bodies- the National Education Association (NEA), } \\
\text { the National Board for Professional Teaching Standards, and } \\
\text { the Center for Teaching Quality }\end{array}$ & $2014 / 15$ \\
\hline 8 & $\begin{array}{l}\text { Leadership competencies for } \\
\text { learner-centered personalized } \\
\text { education }\left(L C \_L C P E\right)\end{array}$ & $\begin{array}{l}\text { The Jobs for the Future (JFF) and the Council of Chief State } \\
\text { School Officers (CCSSO) }\end{array}$ & 2017 \\
\hline
\end{tabular}

Vysvetlivky. V zozname literatúry sú tieto zdroje označené hviezdičkou (*).

\section{Metodika}

V rýchlom úvode projektu nebolo možné využit' formát systematickej prehl'adovej štúdie. Nahradili sme ho tzv. rýchlym prehl'adom (rapid review, Khangura, 2012; NussbaumerStreti, et al., 2016), ktorého podstatou je vol'ba čo najjednoduchších, no efektívnych kritérií výberu, opisu a hodnotenia dát. Za jednu z najlepších variánt tvorby rýchleho prehl'adu sa považuje tzv. Rámcová analýza (Framework Analysis, Ritchie \& Spencer, 1994). Uskutočnili sme ju v prostredí CAQDAS softvéru Atlas.ti, verzia 8 (bližšie in Friese, 2012) podl'a postupu citovaných autoriek. Krok (1) oboznámenie sa s materiálom spočíval v úvodných čítaniach štandardov. Krok (2) identifikovanie tematického rámca tvorila inventarizácia termínov (úrovní, domén) a náčrt stratégie indexovania. Krok (3) indexovanie (v Atlase kódovanie) sa skladal z niekol'kých priechodov dokumentami a vývojom kódovacieho systému. Krok (4) tvorba diagramov spočíval v redukovaní kategórií a tvorbe vizualizácí́ a krok (5) mapovanie a interpretácia $\mathrm{v}$ ich zužitkovaní pre účely výskumu. Prvé tri kroky uplatnili na každý z ôsmych modelov nezávisle na sebe traja členovia tímu (psychológovia - hodnotitelia), ktorých expertíza bola následne využitá aj pri tvorbe diagramov (napr. Obrázok 1), mapovaní a interpretácii. 


\section{Výsledky a diskusia}

Z obsahovej analýzy štandardov vyberáme pre účely príspevku zistenia o štruktúre, metajazyku a záberu oblastí/domén kompetencií. Z Tabul'ky 2 vidiet', že kompetenčné štandardy rôznych organizácií používajú odlišný metajazyk a aplikujú rôzne počty hierarchických úrovní. Z formálneho aspektu však ešte nie je možné presne určit', ktorá štruktúra je efektívnejšia, bude treba systematicky porovnat’ obsahovú stránku.

Tabul'ka 2. Metajazyk modelov identifikovaný rámcovou analýzou $(n=8)$

\begin{tabular}{llcccccc}
\hline Level 1 & --- & Level 2a & Level 2b & Level 2c & Level 3 & Level 4 & Level 5 \\
\cline { 2 - 7 } Názov modelu & Typ & Druh & Názov & Definícia & Obsah1 & Obsah 2 & Obsah 3 \\
\hline ISLLC/NPBEA 2002 & Ed/L & Standard & $\#$ & Action & Behavior & & \\
ELCC/CCSSO 2002 & Ed/L & Standard & $\#$ & Ability & Elements & Indicators & \\
TLMS/TLEC 2010 & TL & Domain & Action & Competency & & & \\
SBTL/Tomal 2014 & TL & Standard & Action & Competency & Functions & & \\
PSEL/NPBEA 2015 & Ed/L & Standard & Title & Statement & Elements & & \\
LCG/NEA 2014/15 & TL & Competency & Title & Definition & Theme & Behavior & 3 stages \\
TLC/NEA 2014/15 & TL & Competency & Title & --- & Competency & Behavior & 4 stages \\
LC_SCPE/CCSSO 2017 & Ed/L & Domain & Title & Competencies & Competency & Indicators & \\
\hline
\end{tabular}

$\overline{\text { Vysvetlivky. Ed/L - educational leadership, TL - teacher leadership, \# - iba číslo namiesto slovnej špecifikácie. }}$

Uchopit' špecifické vzt'ahy medzi formálnou a obsahovou štruktúrou nám pomohli siet’ové vizualizácie. Obrázok 1 znázorňuje transverzálny vzt’ah medzi vertikálnymi úrovňami a horizontálnymi doménami prvého zo štandardov modelu ELCC z r.2002. Novšie vydania štandardov majú vo všeobecnosti zložitejšie štruktúry, než tie pôvodné.

Zhrnutie k VO1. Konštrukciu kompetenčných modelov LvEd v severoamerickom kontexte možno opísat' nasledovne:

Štandardy LvEd použivajú rozdielny metajazyk a štruktúru (hierarchizácia úrovní, záber domén, indikátory), podobné sú v koncipovaní ako poznatky (content knowledge), zručnosti a prax (skills and practices), správanie a atribúty ako dispozičná zložka;

Záber domén v zmysle ich tematického/obsahového zamerania je možné štruktúrovat' do okruhov: (a) hodnôt (misia, vízia, etika); (b) odbornej/pedagogickej kvality (inštruktážny líderšip, inovácie, kurikulum, hodnotenie); (c) manažmentu (zdrojov, rozvoja personálu...); (d) vzt'ahov v kontexte vzdelávania (s rodinou, komunitou, pedagogickou odbornou obcou, riadiacimi telesami); (e) osobnostných kvalít, relevantných pre líderšip. 
Obrázok 1. Ukážka vzt’ahu obsahovej a meta štruktúry modelu (Štandard 1, ELCC/CCSSO Standards, 2002, Zdroj: Autori, 2019)

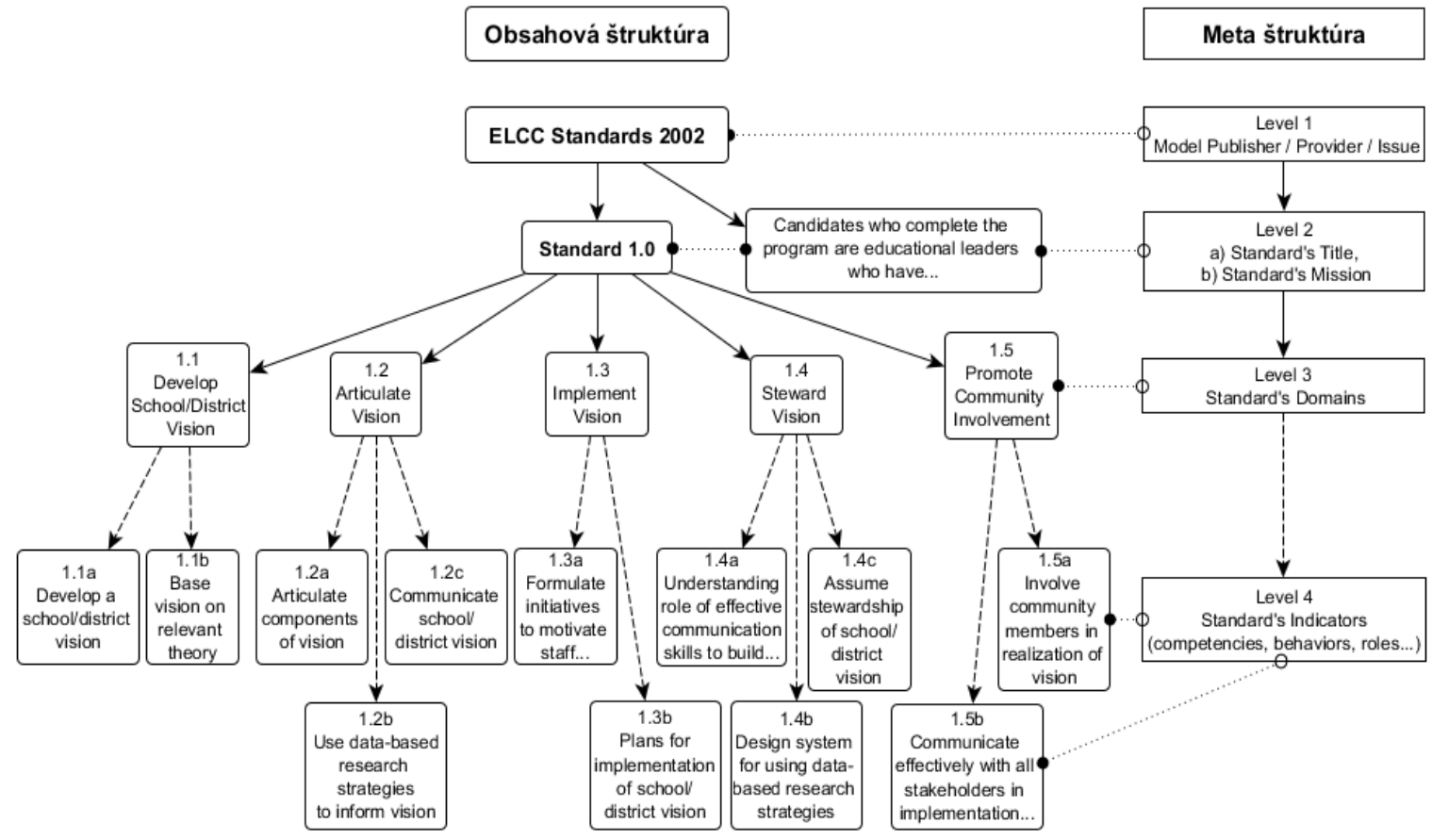

Vysvetlivky: Obsahová štruktúra (vl’avo a v strede) - hierarchická stromová štruktúra relevantných obsahov sa rozvetvuje smerom zhora nadol od základného výroku ("mission") ku špecifickým subtémam (kompetenciám) a následne až k behaviorálnym indikátorom. Meta štruktúra (vpravo) - vertikála zachytáva jazyk jednotlivých úrovní modelu. Niektoré analyzované modely majú viac než 4 úrovne.

K vývoju štandardov. Postupný vývoj štandardov v severoamerickom kontexte je reakciou na meniace sa prostredie ako je rozvoj technológií, zmeny v demografii aj štruktúre rodiny, vystavenie škôl trhovej konkurencii a zvýšená zodpovednost’ za študijné výsledky. Štandardy sú určené všetkým úrovniam vedenia, pričom podl'a vymenovania úrovní ide o riadiacich pracovníkov školy (leaders in administrative roles) a regionálneho školstva (principals, assistant principals, district leaders). Silnie dôraz na študenta a jeho učenie sa, ako aj na význam l'udských vzt'ahov vo vyučovaní (teaching) a učení sa študentov (student learning). Uvedené vývojové trendy modelov znázorňuje Obrázok 2.

Programy zamerané na prípravu v školskom líderstve ašpirujú na získanie akreditácie od Národnej rady pre akreditáciu učitel'ského vzdelávania (the National Council for Accreditation of Teacher Education; NCATE) a požadujú ich záväznost'. NPBEA aktualizovalo pôvodné ISLLC štandardy v roku 2015 s označením Professional Standards for Educational Leaders (PSEL). Tak ako uvedené štandardy boli aktualizáciou pôvodných ISLLC, tak aj hlavná riadiaca organizácia, The Council of Chief State School Officers (CCSSO) aktualizovala štandardy ELCC z roku 2002 v spolupráci s neziskovou organizáciou The Jobs for the Future (JFF). 
Obrázok 2. Vývojová následnost' analyzovaných kompetenčných modelov $(n=8)$

\begin{tabular}{|c|c|c|}
\hline Vydanie & Educational Leadership & Teacher Leadership \\
\hline $2002 / 11$ & $\begin{array}{l}\text { The ISLLC Leadership Standards. The National } \\
\text { Policy Board for Educational Administration. }\end{array}$ & \\
\hline 2002 & $\prod \begin{array}{c}\text { ELCC Standards. The Council } \\
\text { of Chief State School Officers (CCSSO) }\end{array}$ & \\
\hline 2010 & & $\begin{array}{l}\text { eacher Leader Model Standards (TLMS). } \\
\text { eacher Leadership Exploratory Consortium. }\end{array}$ \\
\hline 2014 & & $\begin{array}{l}\text { SBTL - Standards Based Teacher Leadership } \\
\text { Tomal et al. }\end{array}$ \\
\hline 2015 & $\begin{array}{l}\text { Professional Standards for Educational Leaders } \\
\text { (PSEL). The National Policy Board for Educational } \\
\text { Administration. }\end{array}$ & \\
\hline $2014 / 15$ & & $\curvearrowright \begin{array}{l}\text { Leadership Competencies Guide (LCG). } \\
\text { The National Education Association (NEA). }\end{array}$ \\
\hline $2014 / 5$ & & $\begin{array}{l}\text { Teacher Leadership Competencies (TLC). The } \\
\text { National Education Association (NEA). }\end{array}$ \\
\hline 2017 & $\begin{array}{l}\text { Leadership Competencies for Learner-centered, } \\
\text { Personalized Education (LCLCPE). The Jobs for } \\
\text { the Future (JFF). \& the Council of Chief State } \\
\text { School Officers (CCSSO) }\end{array}$ & \\
\hline
\end{tabular}

Výsledkom bol model Leadership Competencies for Learner-centered, Personalized Education (LCLCPE, CCSSO 2017), kde zdôraznili aspekty líderstva pre personalizované, na žiaka zamerané, vzdelávanie. Má byt' pomôckou rozvoja efektívnych „transformatívnych“ lídrov vymedzením vedomostí a zručností, podporujúcich na žiaka zamerané učebné prostredie. Kompetencie sú štrukturované do východiskovej domény (vízia, hodnoty, kultúra lídra) a 3 podporných domén (podpora výkonu druhých, osobné zručnosti lídra a zdiel'aná zodpovednost'). Naprieč nimi prechádzajú témy inovácie, riadenia zmeny a zamerania na študenta.

Druhú líniu vo vývoji štandardov LvEd predstavujú tie, ktoré sú zamerané na učitel'ský líderšip (teacher leadership). Teacher Leadership Exploratory Consortium publikovalo v roku 2010 Teacher Leader Model Standards (2010), sumarizujúce poznatky, zručnosti a kompetencie, ktoré si učitelia potrebujú osvojit' vo vodcovských rolách na školách. Majú 7 domén, opisujúcich aspekty a funkcie učitel'ského líderstva, zamerané na jeho roly, dispozície a aktivity v každodennom fungovaní. Postihujú aj učebnú (learning) klímu a kultúru pre učenie sa študentov ako kritických aspektov pre zvýšenie ich výkonu.

Tím expertov (Tomal et al.,2014) vyvinul štandardy (Standards Based Teacher Leadership), v ktorých syntetizujú nielen uvedený model TLMS z r. 2010, ale aj záväzné štandardy ICLL z r. 2002, čo rozšírili o kl'účové kompetencie identifikované z empirického výskumu LvEd. Prepájajú kompetencie, líderstvo a výsledky zamerané na zlepšenie školy (school improvement). Podl'a autorov učitel'skí lídri môžu mentorovat', obhajovat' (advocate), koučovat' a byt' hovorcami študentov a kolegov na škole a majú zručnosti, podporujúce víziu, misiu a ciele školy, a zároveň i učitel'skú profesiu.

Ďalšia nezávislá iniciatíva učitel'ských asociácií vo vytváraní teacher leadership standards bola výsledkom spolupráce U.S. organizácií: The National Education Association 
(NEA), the National Board for Professional Teaching Standards, and the Center for Teaching Quality, výsledkom boli modely Leadership Competencies Guide (LCG) a The Teacher Leadership Competencies (TLC) (2014/15). Účelom modelov bolo premietnut' vízie učitel'ského líderstva do sady kompetencií, typických pre transformatívne líderstvo. Kompetencie sú rozčlenené na vodcovstvo inštruktážne (zdiel'anie inovatívneho vyučovania s druhými/kolegami), strategické (fungovanie na úrovni mimoškolských, správnych a národných úrovniach pri tvorbe stratégií) a asociačné (ako tvorit’ a viest' tímy).

Za relevantné pre podmienky SR i pre akcentovanie psychologického prístupu považujeme jednotne uplatňovaný prístup $\mathrm{k}$ štandardom koncipovaným ako poznatky (content knowledge), zručnosti a prax (skills and practices), správanie a atribúty ako dispozičnú zložku, kategorizované v 6 (ISLLC Standards, 2002) a 7 (ELCC Standards, 2002) doménach: 1) vízia a misia, 2) vyučovanie a učenie sa, 3) manažovanie systémov a klímy, 5) spolupráca s klúčovými partnermi, 5) etika a integrita a 6) širší kontext vzdelávania. ELCC k podobnému záberu pridáva kategóriu praxe (internship experiences), poskytujúc príležitost' aplikovat' poznatky a zručnosti osvojené v prípravných programoch.

Zhrnutie k VO2. K súvislostiam a trendom vývoja kompetenčných modelov LvEd:

Otvorenost' modelov/štandardov aktualizáciám inšpirovaným najmä zmenami $\mathrm{v}$ prostredí (čo sa premieta do zmien $\mathrm{v}$ očakávaniach na LvEd), aktuálnom poznaní založenom na výskume a reálnych skúsenostiach lídrov a pracovníkov v školstve.

Zahrnutie kategórie učitel'ov do konceptu lídrov v edukácii, čím sa rozšírilo pôvodné chápanie lídrov iba ako riadiacich pracovníkov školy a vyšších úrovní riadenia.

Posúva sa dôraz z pôvodne pedagogicky orientovaných tém (napr. inštruktážny líderšip) na psychologickejšie (holistický pohl'ad na žiaka, vzt’ahový charakter práce lídra).

\section{Závery, limity a perspektívy štúdie}

\section{Závery}

(1) Transformácia školstva prebieha vo svete $v$ rôznych podobách a prioritne je riešená „úroveň“ manažmentu škôl a líderstvo, dominantne skvalitňovanie vzdelávania.

(2) Konceptualizácia kompetencií LvEd v analyzovanom severoamerickom kontexte sa zameriava dvomi smermi: (a) na manažment škôl (school leadership); (b) na učitel'ov (educational/teacher leadership), s prienikmi aj rozdielmi v doménach/kompetenciách.

(3) Existuje pestrost' $v$ národných prístupoch koncipovania kompetenčných modelov (a) školského/edukačného a (b) učitel'ského líderstva, ako aj rozdiely špecifickosti kompetencií a miere zaradenia psychologických parametrov líderšipu.

(4) Konceptualizácie skúmaných štandardov nevyužívajú dostatočne potenciál teoreticko-empirického psychologického poznania efektívneho LvEd. 


\section{Limity}

Zameranie na severoamerický kontext nás ochudobňuje o poznanie kultúrnych aj socioekonomických osobitostí iných častí sveta. Analýza metajazyka modelov zatial' nie je kompletne zdokumentovaná. Chýba tiež konsenzus v preklade termínu „leadership“ a príbuzných termínov. Na tieto rezervy budeme reagovat' osobitnými štúdiami.

\section{Prínos a perspektívy štúdie}

Ked’že medzi ciel'mi aplikačného projektu APVV je vytvorenie národne špecifického kompetenčného modelu LvEd, vykonanou analýzou existujúcich zahraničných modelov sme získali cenné prvé poznatky o spôsobe ich štrukturácie, metajazyku a postupujúcich inováciách. Po komparácii s analogickými analýzami európskych štandardov to umožní rozhodnút', ktoré úrovne, dimenzie či domény zvolíme pre návrh nášho modelu.

\section{Poznámka}

Táto štúdia nadväzuje na štúdiu z tohto zborníka od Sollárovej et al. s názvom Leadership in Education - Characteristics of the Key Concepts [Líderšip v edukácii charakteristika kl'účových konceptov].

\section{Literatúra}

ELCC Standards (2002). Educational Leadership Consortium Council, Washington, DC:

National Policy Board for Educational Administration (NPBEA).

Friese, S. (2012). Qualitative Data Analysis with ATLAS.ti. London: SAGE.

ISLLC Standards (2011). Interstate School Leaders Licensure Consortium, Washington, DC: Author.

Khangura, S. et al. (2012). Evidence summaries: the evolution of a rapid review approach. Systematic Reviews, 1(10), 1-9. http://doi.org/10.1186/2046-4053-1-10

Leadership Competencies for Learner-Centered, Personalized Education (2017). Jobs for the Future \& the Council of Chief State School Officers. Boston, MA: JFF.

Marelli, A.F. (2005). Strategies for developing competency models. Administration and Policy in Mental Health, 32(5/6), 533-560. http://doi.org/10.1007/s10488-005-3264-0

Nussbaumer-Streit, B. et al. (2016). Assessing the validity of abbreviated literature searches for rapid reviews: meta-epidemiologic study. Systematic Reviews, 5(197), 1-7. http://doi.org/10.1186/s13643-016-0380-8

Professional Standards for Educational Leaders (2015). National Policy Board for Educational Administration. Reston, VA: Author. 
Ritchie, J. \& Spencer, L. (1994). Qualitative data analysis for applied policy research. In A. Bryman and R. G. Burgess (Eds.), Analyzing qualitative data (pp. 173-194). London: Routledge. http://doi.org/10.4324/9780203413081_chapter_9

Smutný, P., Procházka, J. \& Vaculík, M. (2014). Developing managerial competency model. In Proceedings of International Conference Hradec Economic Days (pp. 309-3015). Hradec Králové, ČR: University of Hradec Králové.

Teacher Leader Model Standards. (2010). Teacher Leader Exploratory Consortium. Washington, DC. Dostupné z: www.teacherleaderstandards.org/

The Teacher Leadership Competencies. (2014). Center for Teaching Quality, National Board for Professional Teaching Standards, and the National Educ. Association. Dostupné z: https://www.teachingquality.org/library/the-teacher-leadership- competencies/

Tomal, D.E., Schilling, C.A. \& Wilhite, R.K. (2014). The Teacher Leader: Core competencies and strategies for effective leadership. London, UK: Rowman \& Littlefield.

\section{Korespondující autor}

Prof. PhDr. Eva Sollárová, CSc.

Matej Bel University, Faculty of Education, Department of Psychology

Ružová 13, 97404 Banska Bystrica, Slovak Republic

eva.sollarova@umb.sk 


\title{
Work and Organization Psychology 2019
}

Jakub Procházka, Tomáš Kratochvíl, Martin Vaculík (Eds.)

\begin{abstract}
The conference proceedings contain 24 selected papers, presented at the $18^{\text {th }}$ international conference called Work and Organizational Psychology 2019, held in May 2019 in Brno. It includes empirical, review and case studies and introduces research projects from various areas of work psychology. Most of the contributions is devoted to the psychometric characteristics of methods measuring constructs from the field of work and organizational psychology, factors influencing work attitudes and engagement as well as leadership. The studies capture the current knowledge and challenges and the direction of future research in work psychology.
\end{abstract}

Keywords: Work psychology; organizational psychology; managerial psychology; psychometrics; job attitudes; leadership; helping professions; psychology in business

\section{Psychologie práce a organizace 2019}

Jakub Procházka, Tomáš Kratochvíl, Martin Vaculík (Eds.)

\begin{abstract}
Abstrakt
Sborník obsahuje 24 vybraných př́spěvků představených na 18. ročníků mezinárodní konference Psychologie práce a organizace 2019, která se konala v květnu 2019 v Brně. Zahrnuje empirické, přehledové a př́padové studie a představení výzkumných projektů z různích oblastí pracovní psychologie. Největší část příspěvkůse věnuje psychometrickým charakteristikám metod měřících konstrukty z oblasti psychologie práce a organizace, faktorům ovlivňujícím pracovní postoje a engagement a také leadershipu. Jednotlivé studie zachycují současné poznání i výzvy a směřování budoucího pracovně-psychologického výzkumu.
\end{abstract}

Klíčová slova: Psychologie práce; psychologie organizace; manažerská psychologie; psychometrika; pracovní postoje; leadership; pomáhající profese; psychologie v byznysu 


\section{List of authors / Rejstř́k autorů}

Bačová, V.

Bahbouh, R.

Bavolár, J.

Birknerová, Z.

Bobek, M.

Bozogáňová, $M$.

Bożek, A.

Drábová, D.

Droppa, M.

Fabianová, I.

Fedáková, D.

Franc, M.

Frankovský, M.

Gabrhel, V.

Gregar, A.

Heinzová, Z.

Höschlová, E.

$\mathrm{Hu}, \mathrm{Ch} . \mathrm{-H}$.

Chroustová, E.

Kališ, M.

Kentoš, M.

Knorková, A.

Kožárová, Z.

Kubalová, K.

Kubík, R.

Kushch, O.

Linkov, V.

Lisá, E.

Lišková, J.

Lorincová, T.

Lovasová, V.

Loziak, A.

Ma, Sh.-Tz.

Malinowska, D.

Matošková, J.

Pašková, L.

Paulík, K.

Pejřová, I.

Poliach, V.

Sollárová, E.

Šafránková, J. M.

Šikýř, M.
73-80

44-52, 53-64, 65-72

12-21

101-110

81-90

91-100

22-33

154-163

101-110

69-77

34-43

44-52

101-110

136-143

111-118

198-207, 225-234

53-64

136-143

65-72

144-153

119-126

65-72

34-43, 216-224

127-135

44-52

171-180

136-143

144-153

154-163

91-100

171-180

181-188

136-143

22-33

111-118

198-207, 225-234

189-197

111-118

198-207, 225-234

198-207, 225-234

208-215

208-215 
Tokarz, A.

Toman Čerget'ová, I.

Valuš, L.

Zelienková, A.

Žitniaková-Gurgová, B. 198-207, 225-234
22-33

127-135

73-80

216-224 


\section{VĚDECKÁ REDAKCE MASARYKOVY UNIVERZITY}

prof. PhDr. Jiří Hanuš, Ph.D.; PhDr. Jan Cacek, Ph.D.; Mgr. Tereza Fojtová; doc. JUDr. Marek Fryšták, Ph.D.; Mgr. Michaela Hanousková; doc. RNDr. Petr Holub, Ph.D.; doc. Mgr. Jana Horáková, Ph.D.; prof. MUDr. Lydie Izakovičová Hollá, Ph.D.; prof. PhDr. Tomáš Janík, Ph.D., M.Ed.; prof. PhDr. Tomáš Kubíček, Ph.D.; doc. RNDr. Jaromír Leichmann, Dr. PhDr. Alena Mizerová; doc. Ing. Petr Pirožek, Ph.D.; doc. RNDr. Lubomír Popelínský, Ph.D.; Mgr. Kateřina Sedláčková, Ph.D.; doc. RNDr. Ondřej Slabý, Ph.D.; prof. PhDr. Jiří Trávníček, M.A.; doc. PhDr. Martin Vaculík, Ph.D.

Work and Organization Psychology 2019

Psychologie práce a organizace 2019

Editors/editoři: Jakub Procházka, Tomáš Kratochvíl, Martin Vaculík (Eds.)

Publisher/vydavatel: Masaryk University

Issue/vydání: 1.

Date of issue/rok vydání: 2019

This publication did not pass through stylistic revision.

Publikace neprošla jazykovou úpravou.

Electronic publication/Elektronická publikace

ISBN 978-80-210-9488-8 (online; pdf)

https://doi.org/10.5817/CZ.MUNI.P210-9488-2019 
M U II I
PRES S

II U II I

ECON 